

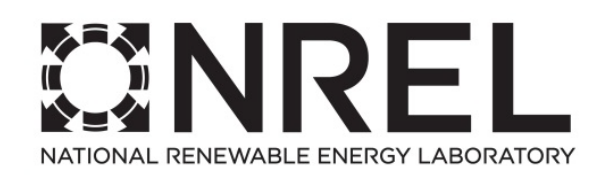

\section{IEA Wind Task 26: Wind Technology, Cost, and Performance Trends in Denmark, Germany, Ireland, Norway, the European Union, and the United States: 2007-2012}

Aisma Vitina

Ea Energy Analyses

Silke Lüers and Anna-Kathrin Wallasch

Deutsche WindGuard

Volker Berkhout

Fraunhofer IWES

Aidan Duffy and Brendan Cleary

Dublin Institute of Technology and Dublin Energy Lab

Leif I. Husabø and David E. Weir

Norwegian Water Resources and Energy Directorate (NVE)

Roberto Lacal-Arántegui

Joint Research Centre, European Commission

M. Maureen Hand and Eric Lantz

National Renewable Energy Laboratory

Kathy Belyeu

Belyeu Consulting

Ryan Wiser, Mark Bolinger, and Ben Hoen Lawrence Berkeley National Laboratory

NREL is a national laboratory of the U.S. Department of Energy Office of Energy Efficiency \& Renewable Energy Operated by the Alliance for Sustainable Energy, LLC

This report is available at no cost from the National Renewable Energy Laboratory (NREL) at www.nrel.gov/publications.

National Renewable Energy Laboratory 15013 Denver West Parkway Golden, CO 80401

303-275-3000 • www.nrel.gov
Technical Report

NREL/TP-6A20-64332

June 2015

Contract No. DE-AC36-08G028308 


\title{
NOTICE
}

This report was prepared as an account of work sponsored by an agency of the United States government. Neither the United States government nor any agency thereof, nor any of their employees, makes any warranty, express or implied, or assumes any legal liability or responsibility for the accuracy, completeness, or usefulness of any information, apparatus, product, or process disclosed, or represents that its use would not infringe privately owned rights. Reference herein to any specific commercial product, process, or service by trade name, trademark, manufacturer, or otherwise does not necessarily constitute or imply its endorsement, recommendation, or favoring by the United States government or any agency thereof. The views and opinions of authors expressed herein do not necessarily state or reflect those of the United States government or any agency thereof.

This report is available at no cost from the National Renewable Energy Laboratory (NREL) at www.nrel.gov/publications.

Available electronically at SciTech Connect http:/www.osti.gov/scitech

Available for a processing fee to U.S. Department of Energy and its contractors, in paper, from:

\author{
U.S. Department of Energy \\ Office of Scientific and Technical Information \\ P.O. Box 62 \\ Oak Ridge, TN 37831-0062 \\ OSTI http://www.osti.gov \\ Phone: 865.576.8401 \\ Fax: 865.576.5728 \\ Email: reports@osti.gov
}

Available for sale to the public, in paper, from:

\author{
U.S. Department of Commerce \\ National Technical Information Service \\ 5301 Shawnee Road \\ Alexandra, VA 22312 \\ NTIS http://www.ntis.gov \\ Phone: 800.553 .6847 or 703.605 .6000 \\ Fax: 703.605.6900 \\ Email: orders@ntis.gov
}




\section{Acknowledgements}

This report has been sponsored by the International Energy Agency (IEA) Wind Implementing Agreement for Co-operation in the Research, Development, and Deployment of Wind Energy Systems (IEA Wind), and funded by the respective entities in the participating countries of Task 26, The Cost of Wind Energy, including Denmark, Germany, Ireland, Norway, the European Commission, and the United States. The authors of this report would like to thank the IEA Wind Executive Committee members for supporting this work, particularly those members who sponsor the corresponding research in each of the participating countries.

The authors are grateful to the reviewers of specific country chapters or of the entire report who provided valuable insights and input including Jørgen Lemming (J Lemming Rådgivning), Poul Erik Morthorst (Technical University of Denmark - Wind Energy), Edward James Smith (Danish Energy Agency), Martin Risum Bøndergaard (Danish Wind Industry Association), Stefan Faulstich (Fraunhofer IWES), Franciska Klein (Forschungszentrum Jülich GmbH, Project Management Jülich), Dr.-Ing. Knud Rehfeldt (Deutsche WindGuard), Peter Kavanagh, Highfield Energy, Anton J. Eliston, (Norwegian Water Resources and Energy Directorate), Alberto Ceña, (Spanish Wind Association (AEE)), Ed DeMeo, (Renewable Energy Consulting Services (RECS)), and Paul Schwabe, (National Renewable Energy Laboratory (NREL)). We also thank the editing team at PWT Communications including Patricia Weis-Taylor and Rick Hinrichs for editing, graphic design, and formatting the report. 


\section{Table of Contents}

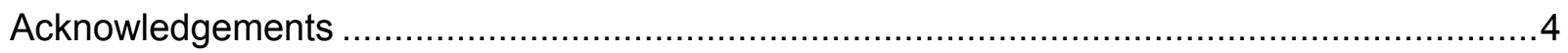

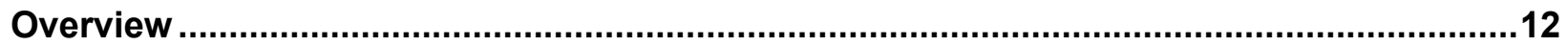

Chapter 1. Wind Energy Development in Denmark .......................................................16

Domestic Wind Energy Capacity, Production, and Targets.............................................. 16

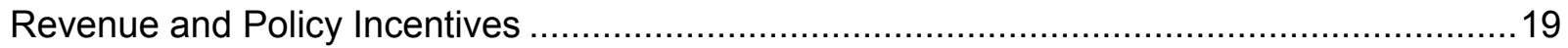

Wind Energy Project Trends in Denmark since 2008 ............................................... 20

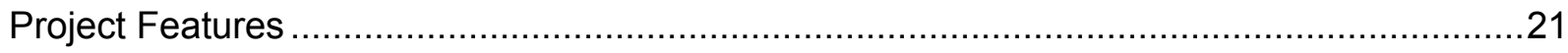

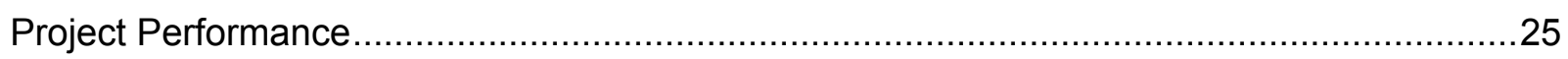

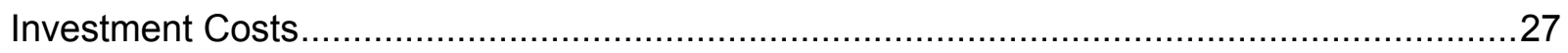

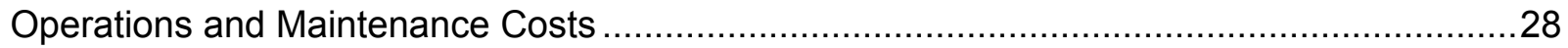

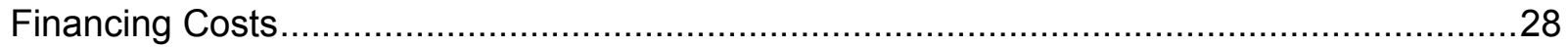

Cost of Wind Energy Generation in Denmark in 2008 and 2012 .................................29

Summary of Wind Projects in Denmark 2008 to 2012 .................................................. 36

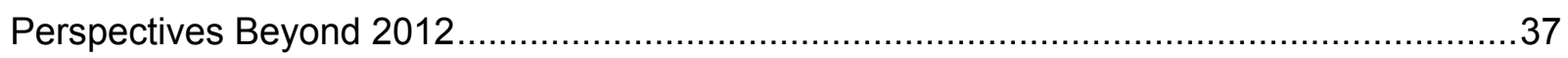

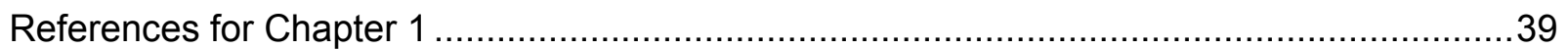

Appendix 1-A. Sample Size and Project Data for Denmark ......................................... 42

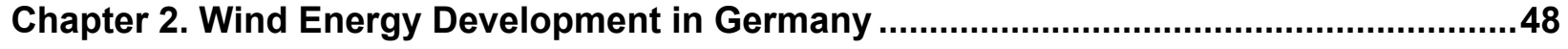

Domestic Wind Energy Capacity, Production, and Targets...........................................48

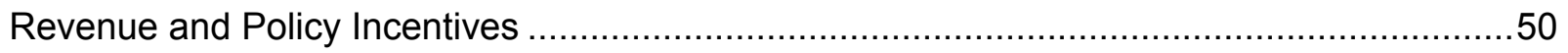

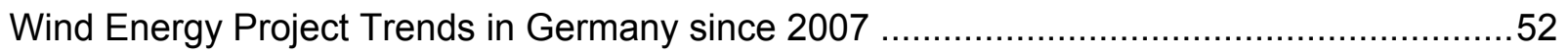

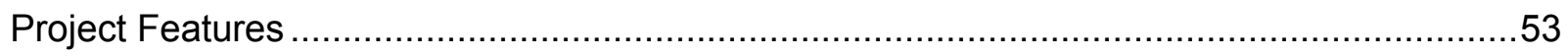

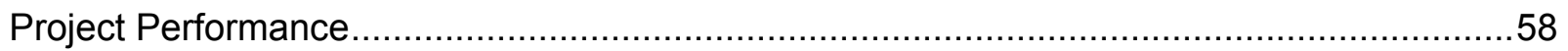

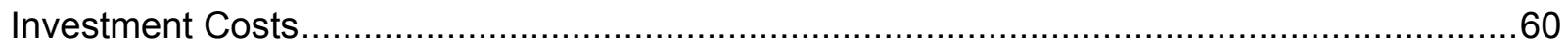

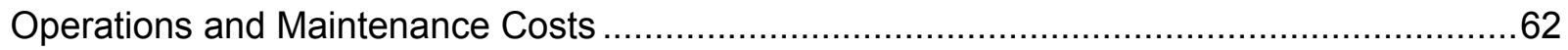

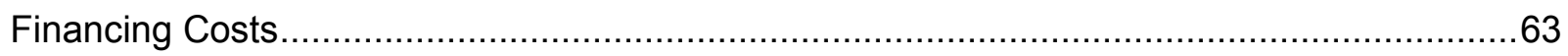

Cost of Wind Energy Generation in Germany in 2008 and 2012 ....................................64

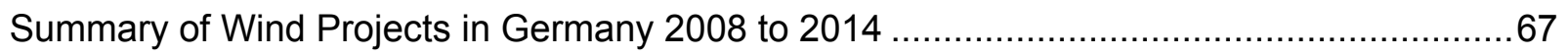

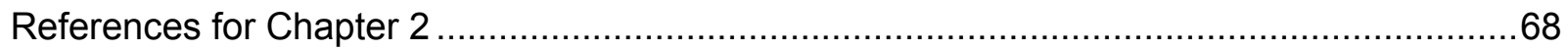

Appendix 2-A Sample Size and Project Data for Germany .............................................69

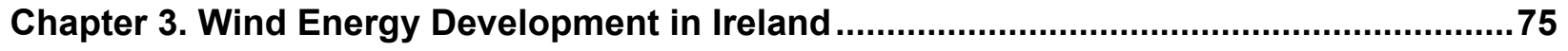

Domestic Wind Energy Capacity, Production, and Targets.............................................75

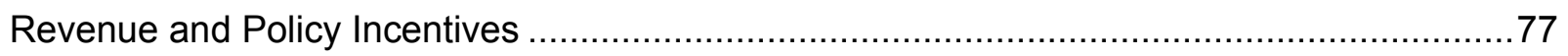

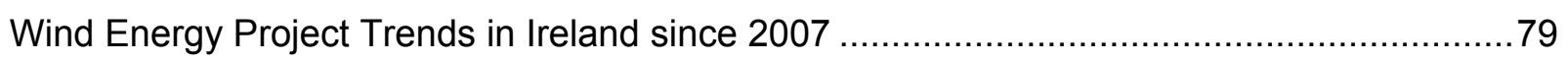

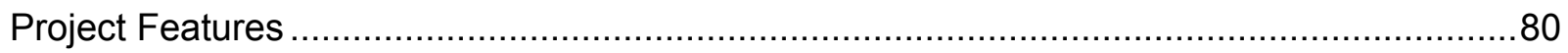

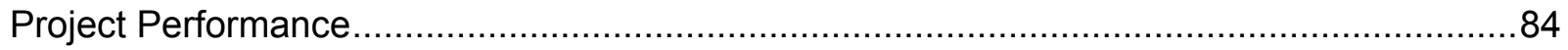




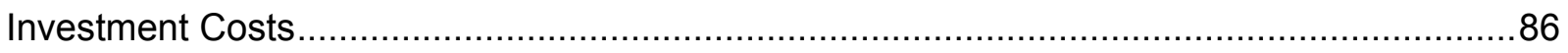

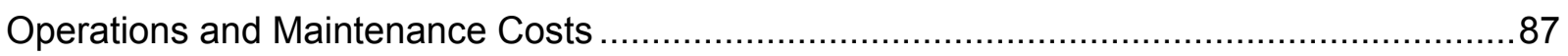

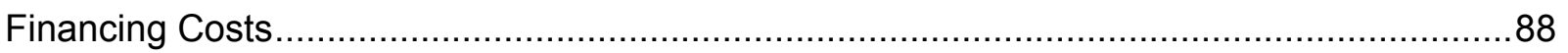

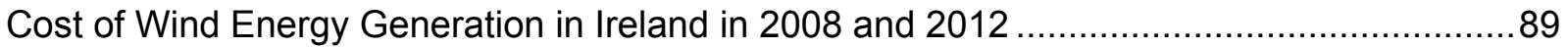

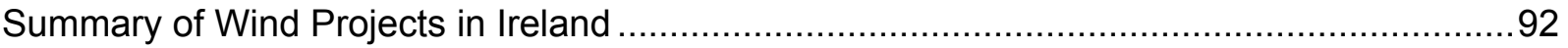

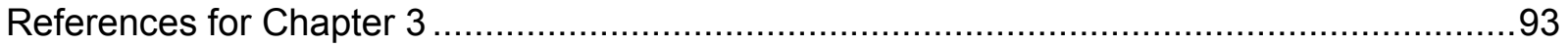

Appendix 3-A. Sample Size, Project Data, and Methodology for Ireland ...........................95

Chapter 4. Wind Energy Development in Norway .......................................................101

Domestic Wind Energy Capacity, Production, and Targets..........................................101

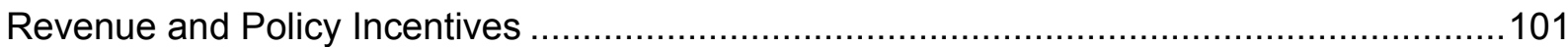

Wind Energy Project Trends in Norway since 2007 ................................................ 103

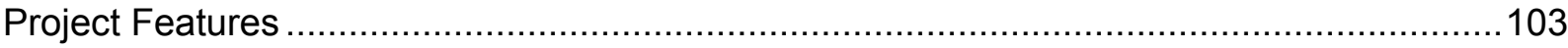

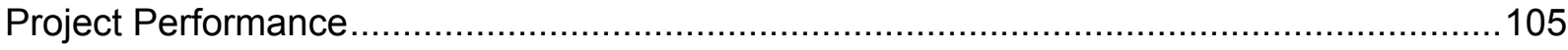

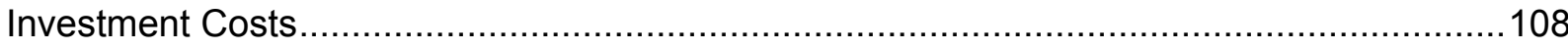

Operations and Maintenance Costs ...................................................................... 110

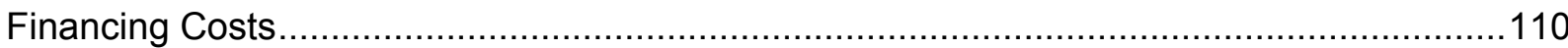

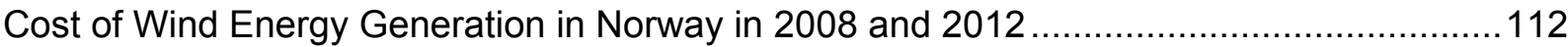

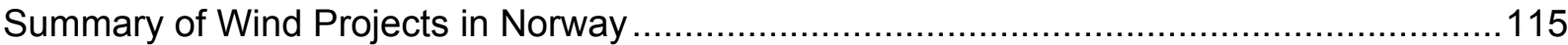

Appendix 4-A Sample Size and Project Data for Norway …......................................116

Chapter 5. Wind Energy Development in the European Union......................................121

Domestic Wind Energy Capacity, Production, and Targets.......................................... 121

Revenue and Policy Incentives ........................................................................... 123

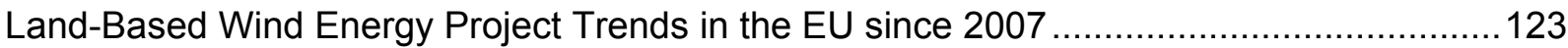

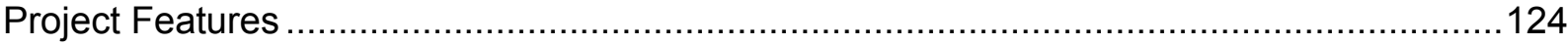

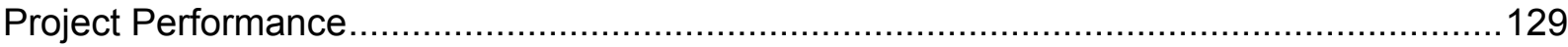

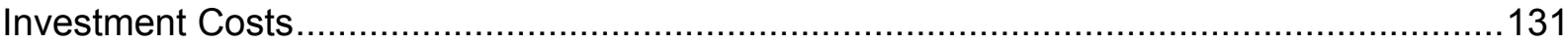

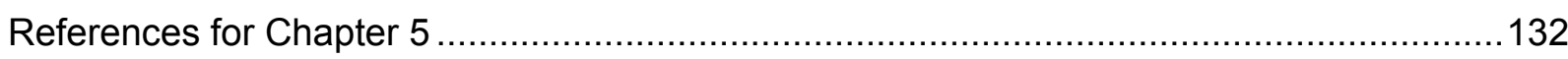

Appendix 5-A. Sample Size and Project Data for the European Union............................... 132

Chapter 6. Wind Energy Development in the United States ............................................137

Domestic Wind Energy Capacity, Production, and Targets..........................................137

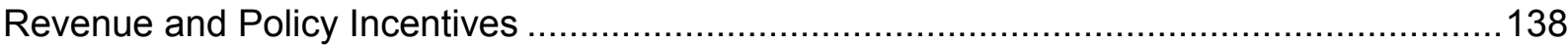

Wind Energy Project Trends in the United States since 2007 ...................................... 140

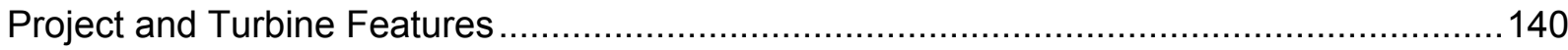

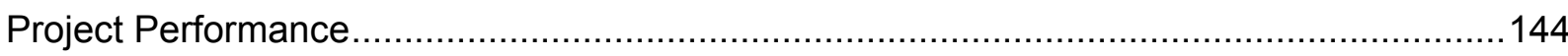

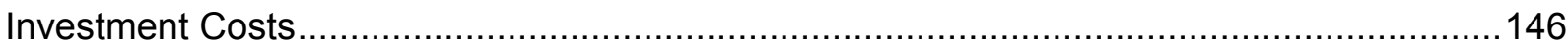

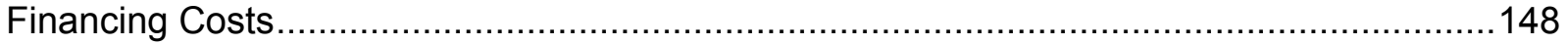


Cost of Wind Energy Generation in the United States in 2008 and 2012 ........................ 150

Summary of Wind Project Trends in United States ....................................................... 153

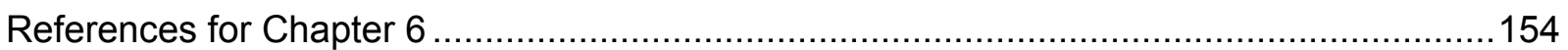

Appendix 6-A. Sample Size and Project Data for the United States .................................154

Appendix 1 Methodology ..............................................................................................161

\section{List of Figures}

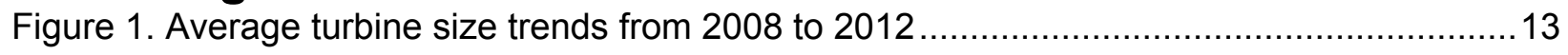

Figure 2. Trends in wind plant specific power and hub height from 2007 to 2012 in the United

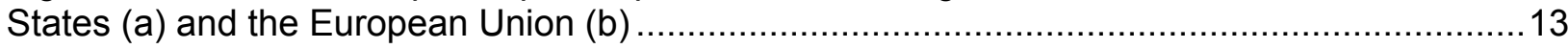

Figure 3. LCOE trend from 2008 to 2012 with some 2014 examples ..................................... 15

Figure 1-1. Cumulative and annual wind installations in Denmark ......................................18

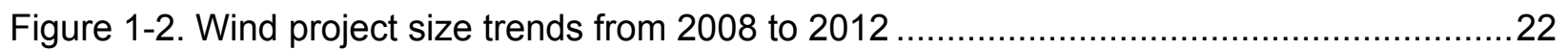

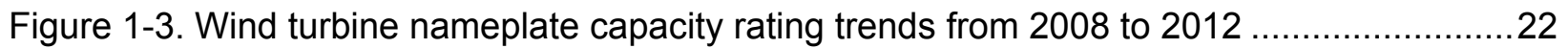

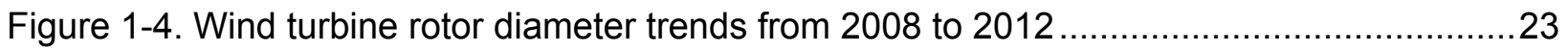

Figure 1-5. Wind turbine hub height trends from 2008 to 2012 .........................................23

Figure 1-6. Wind turbine specific power for projects installed from 2008 to $2012 \ldots \ldots \ldots \ldots \ldots \ldots . . . . .24$

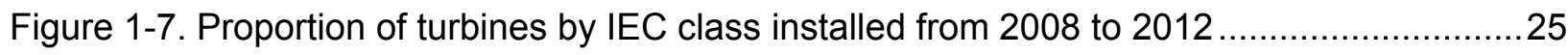

Figure 1-8. Average annual wind speed for projects installed from 2008 to 2012 ...................26

Figure 1-9. Full-load hours and capacity factor for projects installed from 2008 to 2012,

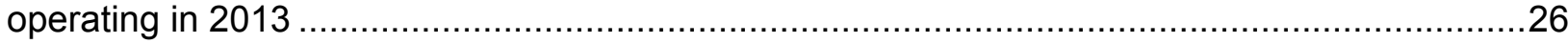

Figure 1-10. Investment costs for wind projects installed from 2008 to 2012 .......................27

Figure 1-11. LCOE, policy impact, and required revenue in Denmark in 2008 and 2012 ..........32

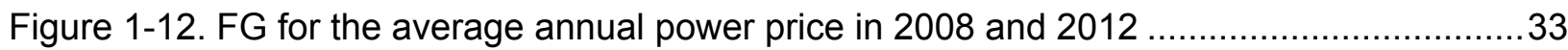

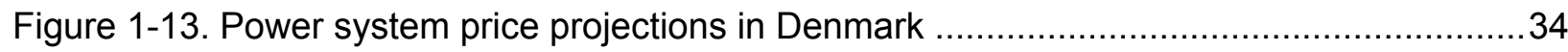

Figure 1-14. Average market price and wind power realized price projections to $2035 \ldots \ldots \ldots \ldots . . . .35$

Figure 2-1. Cumulative and annual wind installations in Germany ....................................49

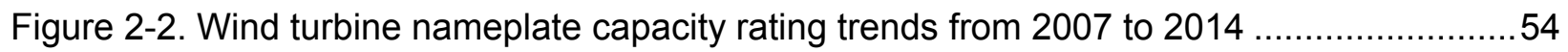

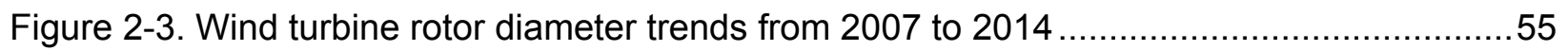

Figure 2-4. Wind turbine hub height trends from 2007 to 2014 ...........................................56

Figure 2-5. Wind turbine specific power trends from 2007 to 2014 .....................................57

Figure 2-6. Proportion of turbines by IEC class installed in Germany from 2007 to the first half of

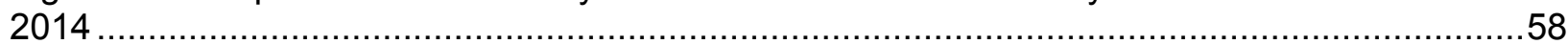

Figure 2-7. Full-load hours/capacity factor for projects installed from 2007 to $2011 \ldots \ldots \ldots \ldots \ldots . \ldots 59$

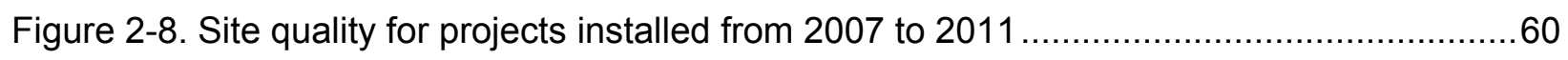

Figure 2-9. Investment costs for projects installed from 2008 to 2012 ..................................61

Figure 2-10. O\&M costs in the first year of operation for projects installed from 2008 to 2012 ...62

Figure 2-11. Wind energy revenue and policy incentives in Germany at a typical site in 2008 and at coastal and inland wind sites in 2012 
Figure 3-1. Cumulative and annual wind installations in the Republic of Ireland .....................76

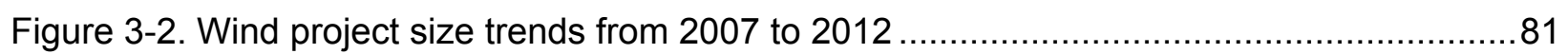

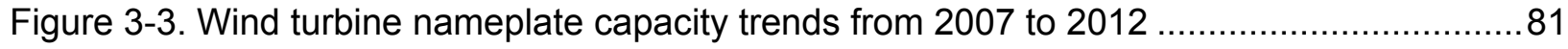

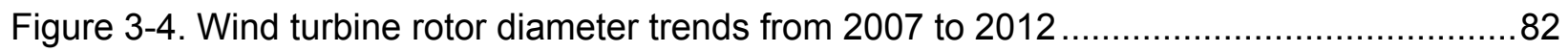

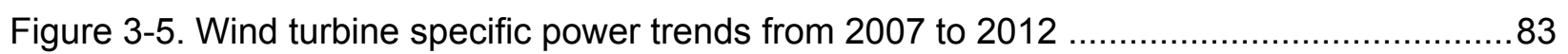

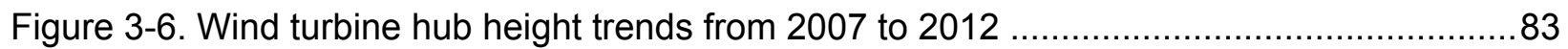

Figure 3-7. Proportion of turbines by IEC class installed from 2007 to 2012 .........................84

Figure 3-8. Annual average wind speed for projects installed from 2007 to 2012, operating in

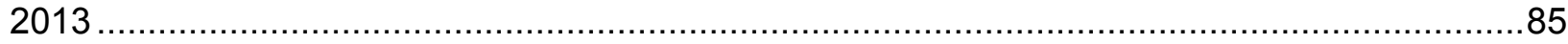

Figure 3-9. Full-load hours for projects installed from 2007 to 2012, operating in 2013 ............86

Figure 3-10. Investment costs for projects installed from 2007 to 2012 ................................ 87

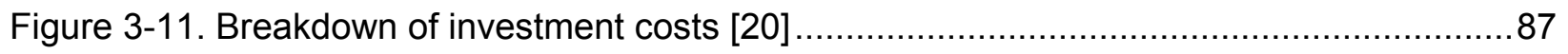

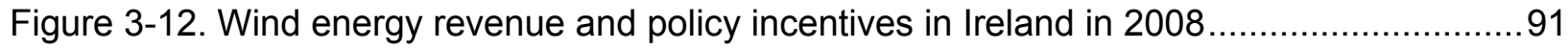

Figure 3-13. Wind energy revenue and policy incentives in Ireland in 2012 ...........................92

Figure 4-1. Cumulative and annual wind installations in Norway......................................102

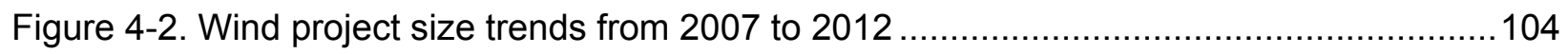

Figure 4-3. Wind turbine machine nameplate capacity trends from 2007 to $2012 \ldots \ldots \ldots \ldots \ldots . . . . .104$

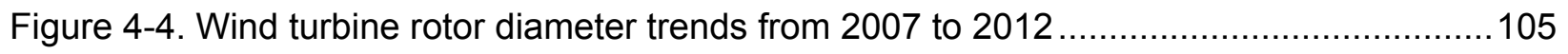

Figure 4-5. Wind turbine hub height trends from 2007 to 2012 ......................................... 106

Figure 4-6. Annual average wind speed for projects installed from 2007 to $2012 \ldots \ldots \ldots \ldots \ldots . . . .106$

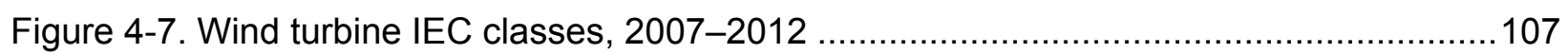

Figure 4-8. Full-load hours for projects installed from 2007 to 2011, operating in 2012 ..........108

Figure 4-9. Investment costs for projects installed from 2007 to 2012 ................................ 109

Figure 4-10. CAPEX breakdown, 2007-2012 ............................................................. 109

Figure 4-11. Estimated average breakdown of O\&M costs for projects installed from 2007 to

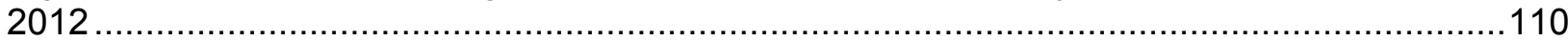

Figure 4-12. Wind energy revenue and policy incentives in Norway in 2008, 2012, and 2014.114 Figure 4-13. FG sensitivity analysis for 2008 and 2012 projects, and a 2014 reference project

Figure 5-1. Cumulative and annual wind installations in the EU and projections for 2015 and

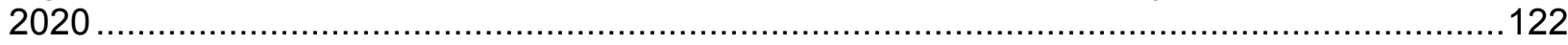

Figure 5-2. Evolution of average wind project size (MW) ............................................ 124

Figure 5-3. Turbine nameplate capacity rating (MW) in the EU, 2007-2012 .....................126

Figure 5-4. Evolution of the turbine rotor diameter in the EU, 2007-2012 ..........................127

Figure 5-5. Evolution of the specific power of wind turbines installed in the EU from 2007 to

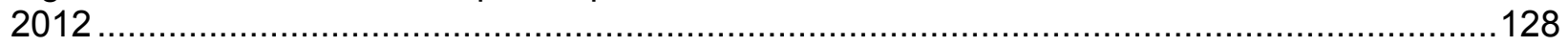

Figure 5-6. Evolution of the hub height in EU wind plants, 2007-2012 ….......................... 128

Figure 5-7. Summary of wind energy performance in the EU ..........................................130

Figure 5-8. Country-level performance in full-load hours per year.....................................130

Figure 5-9. Project investment costs in the EU, 2007-2012 ......................................131 
Figure 6-1. Cumulative and annual wind installations in the United States ........................... 139

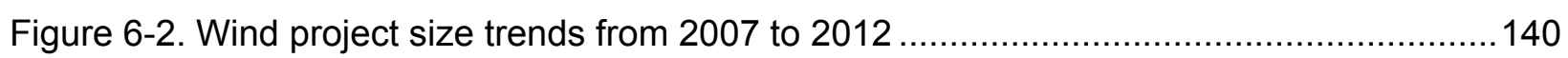

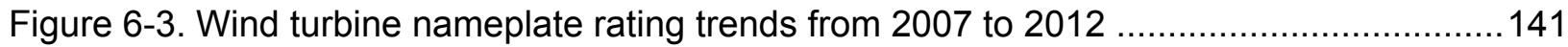

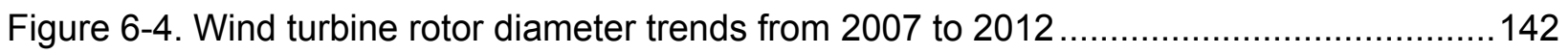

Figure 6-5. Wind turbine specific power trends from 2007 to 2012 .................................... 143

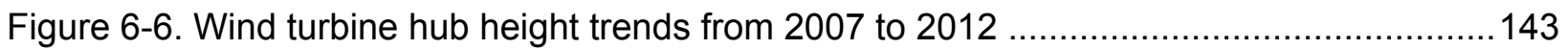

Figure 6-7. Proportion of turbines by IEC class installed from 2007 to $2012 \ldots \ldots \ldots \ldots \ldots \ldots \ldots \ldots . . . . . . . . .144$

Figure 6-8. Full-load hours and capacity factors for projects installed from 2007 to 2012 ,

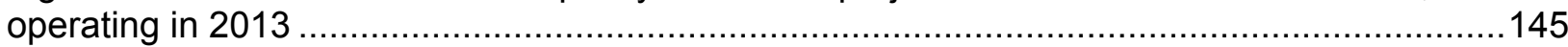

Figure 6-9. Annual average wind speed for projects installed from 2007 to 2012 ................. 146

Figure 6-10. Investment costs for projects installed from 2007 to 2012 ...............................147

Figure 6-11. Weighted Average Cost of Capital for projects installed from 2007 to 2012 ........ 149

Figure 6-12. LCOE for 2008 and 2012 wind plants, including required revenue and policy contributions relative to PPA price ranges....

\section{List of Tables}

Table 1. Primary Revenue and Policy Incentives for Wind Projects in 2012 ..........................15

Table 1-1. Cumulative and Annual Capacity Installed in Denmark ....................................... 19

Table 1-2. Annual Capacity (MW) Additions Installed in Denmark ......................................19

Table 1-3. Wind Energy Financing Terms in Denmark ....................................................29

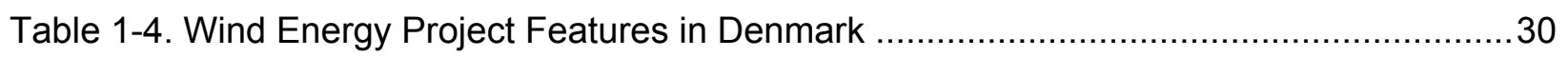

Table 1-5. Wind Energy Policy and Revenue Incentives in Denmark ................................... 31

Table 1-6. Financial Gap Estimates Based on Various Market Power Price Projections ............35

Table 1-7. LCOE, Policy Impact, and Required Revenue in Denmark for 2008 and 2012 .........36

Table 1-8. Comparison of the Impacts of the Different Subsidy Regimes on the Relative

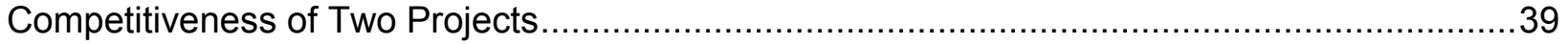

Table 1-9. Definitions and Sample Size for Denmark ...................................................... 43

Table 1-10. Wind Project Size Statistics ........................................................................ 44

Table 1-11. Wind Turbine Nameplate Capacity Rating Statistics .......................................44

Table 1-12. Wind Turbine Rotor Diameter Statistics......................................................... 44

Table 1-13. Wind Turbine Hub Height Statistics ............................................................ 45

Table 1-14. Wind Turbine Specific Power Statistics ............................................................ 45

Table 1-15. Wind Turbine IEC Class Statistics ............................................................... 45

Table 1-16. Average Annual Wind Speed Statistics ......................................................46

Table 1-17. Capacity Factor and Full Load Hour Statistics in 2013 .....................................46

Table 1-18. Investment Costs Statistics....................................................................4 4

Table 2-1. Cumulative and Annual Capacity (GW) Installed in Germany ...............................49

Table 2-2 Typical Wind Energy Financing Terms in Germany...........................................63

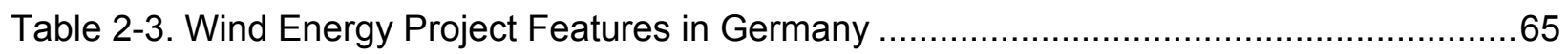


Table 2-4. Wind Energy Policy and Revenue Incentives in Germany ..................................65

Table 2-5. Wind Plant LCOE Summary with Policy and Revenue Components........................66

Table 2-6. Definitions and Sample Size for Germany ....................................................... 70

Table 2-7. Wind Turbine Nameplate Capacity Rating Statistics ........................................71

Table 2-8. Wind Turbine Rotor Diameter Statistics........................................................ 71

Table 2-9. Wind Turbine Hub Height Statistics ................................................................ 71

Table 2-10. Wind Turbine Specific Power Statistics ......................................................... 72

Table 2-11. Wind Turbine IEC Class Statistics .................................................................. 72

Table 2-12. Full Load Hours/Capacity Factors in 2012 Statistics ..........................................73

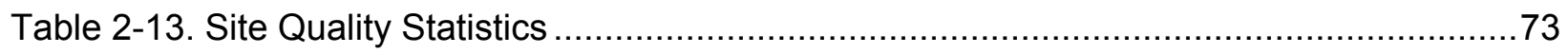

Table 2-14. Investment Costs Statistics....................................................................... 74

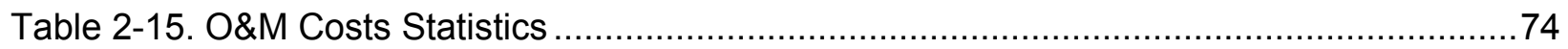

Table 3-1. Cumulative and Annual Capacity (MW) Installed in the Republic of Ireland.............76

Table 3-2. Wind Energy Financing Terms in Ireland ................................................... 88

Table 3-4. Wind Energy Project Features in Ireland .....................................................90

Table 3-5. Wind Energy Policy and Revenue Incentives in Ireland .....................................91

Table 3-6. Wind Plant LCOE Summary with Policy and Revenue Components.......................92

Table 3-7. Sample Size for Ireland ........................................................................ 95

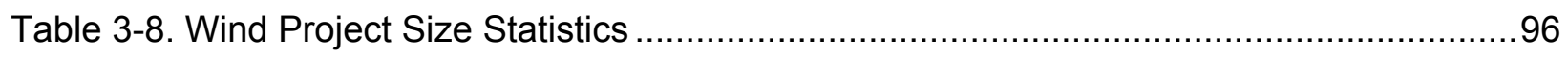

Table 3-9. Turbine Nameplate Capacity Statistics ......................................................... 96

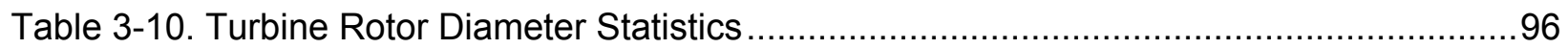

Table 3-11. Turbine Specific Power Statistics .......................................................... 97

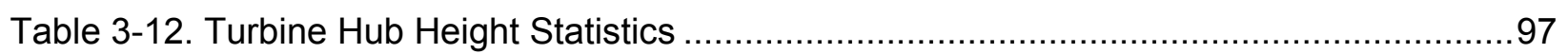

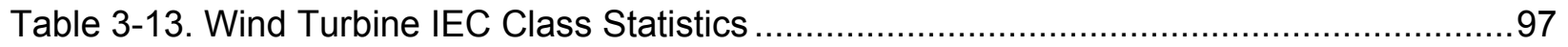

Table 3-14. Annual Average Wind Speed Statistics ....................................................... 98

Table 3-15. Full Load Hours/Capacity Factor Statistics ................................................98

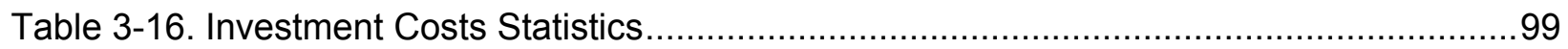

Table 4-1. Cumulative and Annual Capacity (GW) Installed in Norway............................... 102

Table 4-2. Wind Energy Project Features in Norway ..................................................... 112

Table 4-3. Wind Energy Financing Terms in Norway ........................................................ 112

Table 4-4. Wind Energy Policy and Revenue Incentives in Norway ..................................113

Table 4-5. LCOE, Revenue and Policy Incentives, and Financial Gap for 2008 and 2012......115

Table 4-6. Definitions and Sample Size for Norway .................................................... 117

Table 4-7. Wind Turbine Project Size Statistics ............................................................118

Table 4-8. Wind Turbine Nameplate Capacity Rating Statistics ..........................................118

Table 4-9. Wind Turbine Rotor Diameter Statistics........................................................ 118

Table 4-10. Wind Turbine Hub Height Statistics ......................................................... 119

Table 4-11. Average Annual Wind Speed Statistics ...................................................... 119

Table 4-12. Wind Turbine IEC Class Statistics ...........................................................119 
Table 4-13. Full Load Hours Statistics ................................................................... 120

Table 4-14. Investment Costs Statistics..................................................................... 120

Table 5-1. Cumulative Capacity (GW) Installed in the EU ........................................... 121

Table 5-2. Annual Capacity (GW) Installed in the EU ...................................................121

Table 5-3. EU Member States and Main Support Systems for Wind Energy ......................... 123

Table 5-4. Definitions and Sample Size for the EU ...................................................... 133

Table 5-5. Wind Project Size Statistics ....................................................................... 134

Table 5-6. Turbine Nameplate Capacity Rating Statistics ................................................ 134

Table 5-7. Turbine Rotor Diameter Statistics ................................................................... 134

Table 5-8. Turbine Specific Power Statistics ............................................................ 135

Table 5-9. Turbine Hub Height Statistics .................................................................. 135

Table 5-10. Project Investment Costs Statistics …..................................................... 136

Table 6-1. Cumulative and Annual Capacity (GW) Installed in the United States ..................139

Table 6-2. Example Wind Energy Project Financing Terms in the United States .................... 149

Table 6-3. Wind Energy Project Features in the United States ........................................ 151

Table 6-4. Wind Energy Policy and Revenue Incentives in the United States........................152

Table 6-5. Wind Plant LCOE Summary with Policy and Revenue Components...................... 152

Table 6-6. Sample Size for the United States .............................................................. 156

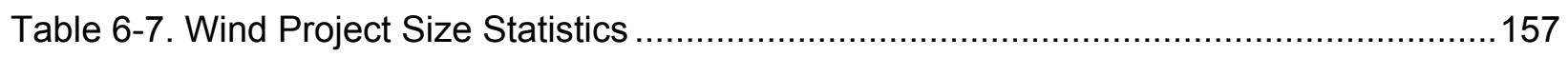

Table 6-8. Wind Turbine Nameplate Capacity Rating Statistics ........................................ 157

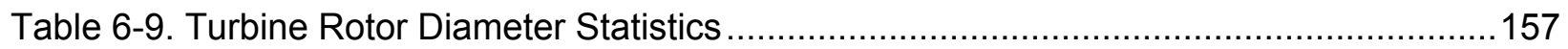

Table 6-10. Wind Turbine Specific Power Statistics .................................................. 158

Table 6-11. Wind Turbine Hub Height Statistics ........................................................ 158

Table 6-12. Proportion of Turbines Installed per IEC Class ............................................ 158

Table 6-13. Full Load Hours and Capacity Factor Statistics ..............................................159

Table 6-14. Average Annual Wind Speed Statistics ....................................................... 159

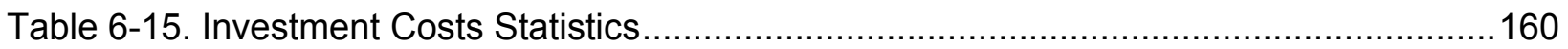

Table 6-16. Weighted Average Cost of Capital Statistics ................................................ 160

Table A1-1. Wind Energy Project Features Used to Estimate LCOE ...................................162

Table A1-2. Wind Energy Policy Incentives Used to Estimate Revenue Requirements ........... 163

Table A1-3. Cash Flow Model Outputs ........................................................................ 163 


\section{Overview}

The International Energy Agency Implementing Agreement for cooperation in Research, Development, and Deployment of Wind Energy Systems (IEA Wind) Task 26-The Cost of Wind Energy represents an international collaboration dedicated to exploring past, present and future cost of wind energy. This report provides an overview of recent trends in wind plant technology, cost, and performance in those countries that are currently represented by participating organizations in IEA Wind Task 26: Denmark, Germany, Ireland, Norway, and the United States as well as the European Union.

This report builds from a similar previous analysis (Schwabe et al., 2011) exploring the differences in cost of wind energy in 2008 among countries participating in IEA Wind Task 26 at that time. The levelized cost of energy (LCOE) is a widely recognized metric for understanding how technology, capital investment, operations, and financing impact the life-cycle cost of building and operating a wind plant. Schwabe et al. (2011) apply a spreadsheet-based cash flow model developed by the Energy Research Centre of the Netherlands (ECN) to estimate LCOE. This model is a detailed, discounted cash flow model used to represent the various cost structures in each of the participating countries from the perspective of a financial investor in a domestic wind energy project. This model is used for the present analysis as well, and comparisons are made for those countries who contributed to both reports, Denmark, Germany, and the United States.

Each country chapter in this report discusses three primary topics. ${ }^{1}$ The first section of each chapter describes the wind industry in terms of installed capacity along with near- and mediumterm projections if available. Revenue and policy incentives are also discussed. The second section details certain turbine- and project-level trends in the wind industry from 2007 (or 2008) to 2012, including wind plant size, turbine size, project performance, investment costs, operation and maintenance (O\&M) costs, and project financing. In each of these cases, a statistical representation of individual project data is provided to the extent possible. The third section reports the estimated LCOE for representative wind plants in 2008 and 2012, including discussion of typical power-sale prices for wind and the value of policy instruments.

Over this period from 2008 to 2012, installed capacity has increased in each country represented. The wind turbine size, as defined by rated capacity, rotor diameter and hub height has also grown as shown in Figure 1. In addition to scaling turbine size, the specific power, or ratio of machine rating $(\mathrm{W})$ to rotor swept area $\left(\mathrm{m}^{2}\right)$ has been decreasing in most countries. Both a reduction in specific power and increased hub height serve to increase energy capture for a given turbine. The larger rotor extracts more energy from the wind field while a taller tower places the rotor in a higher wind speed location which increases energy capture. Larger size components generally imply an increase in capital investment cost, but this incremental cost may be offset by the value of the increased energy capture. In the United States, reduced specific power has been a prominent trend; while in Europe, technology advances have generally emphasized higher hub height as shown in Figure 2. A box and whiskers format is used to represent the sample of turbines in a given year including the median (horizontal line), average (diamond), $25^{\text {th }}$ to $75^{\text {th }}$ percentile (box), and minimum and maximum (whiskers).

\footnotetext{
${ }^{1}$ The European Union chapter discusses recent trends. Cost of energy analysis is not included due to insufficient data.
} 

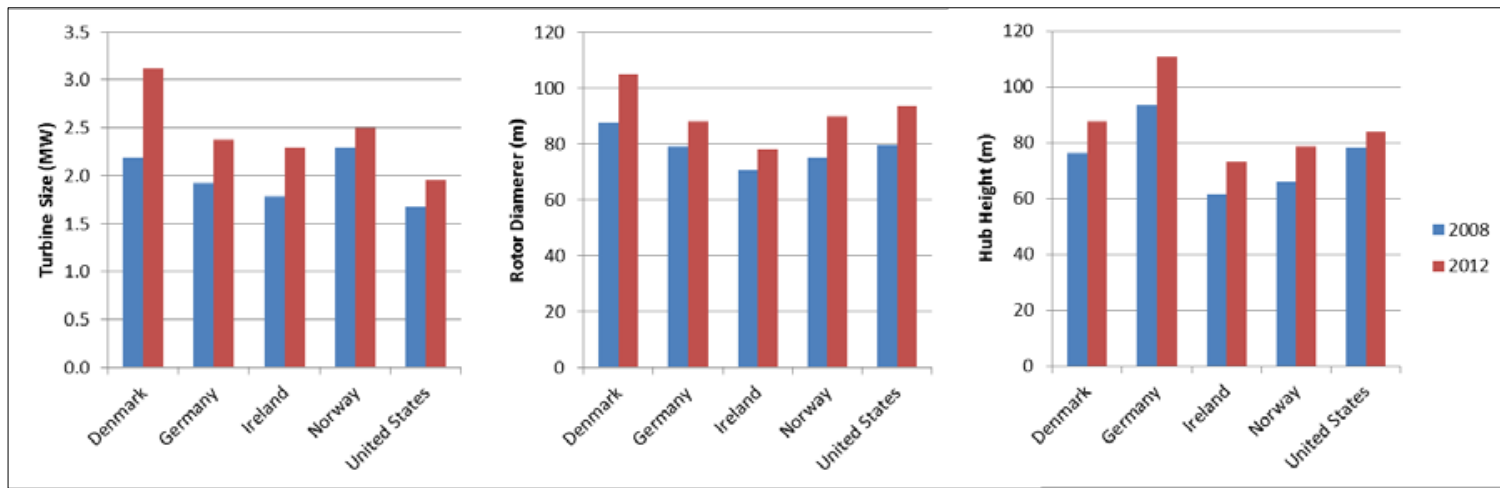

Figure 1. Average turbine size trends from 2008 to 2012

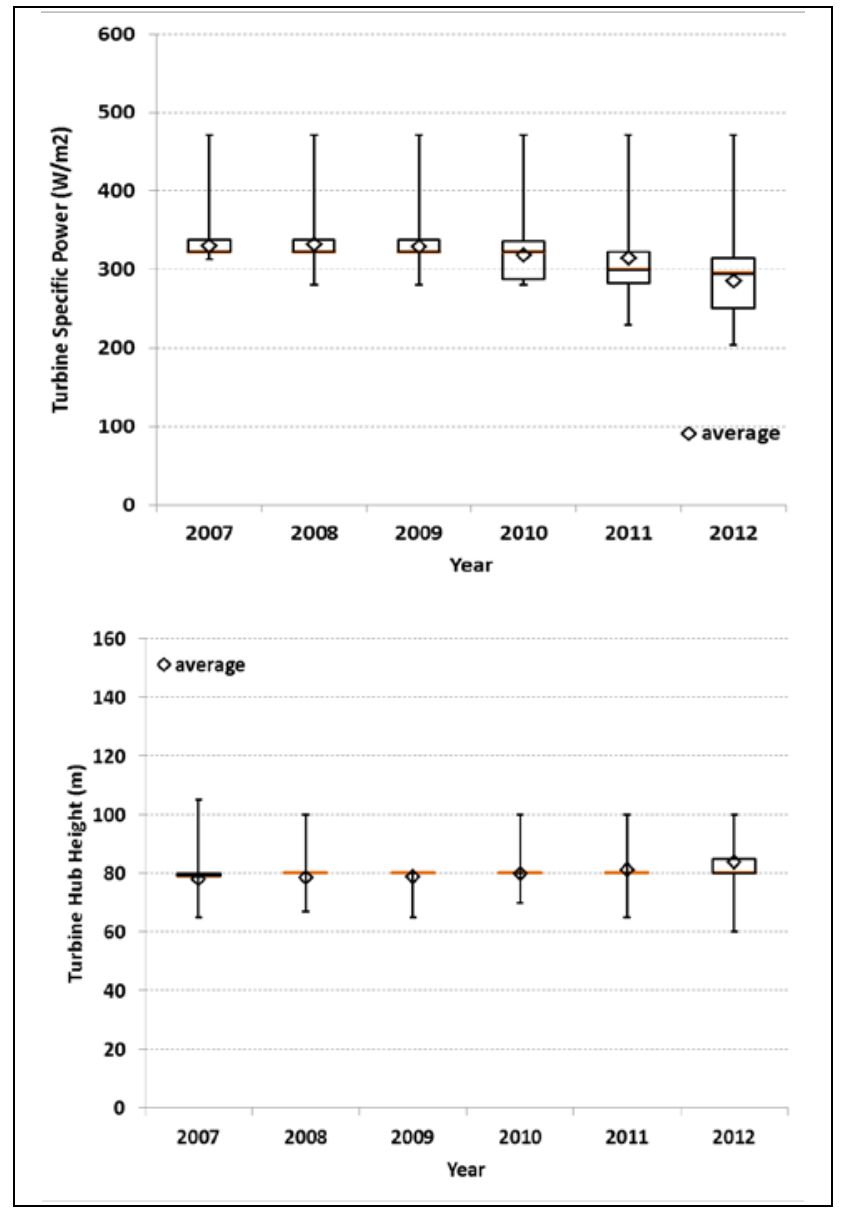

a) United States
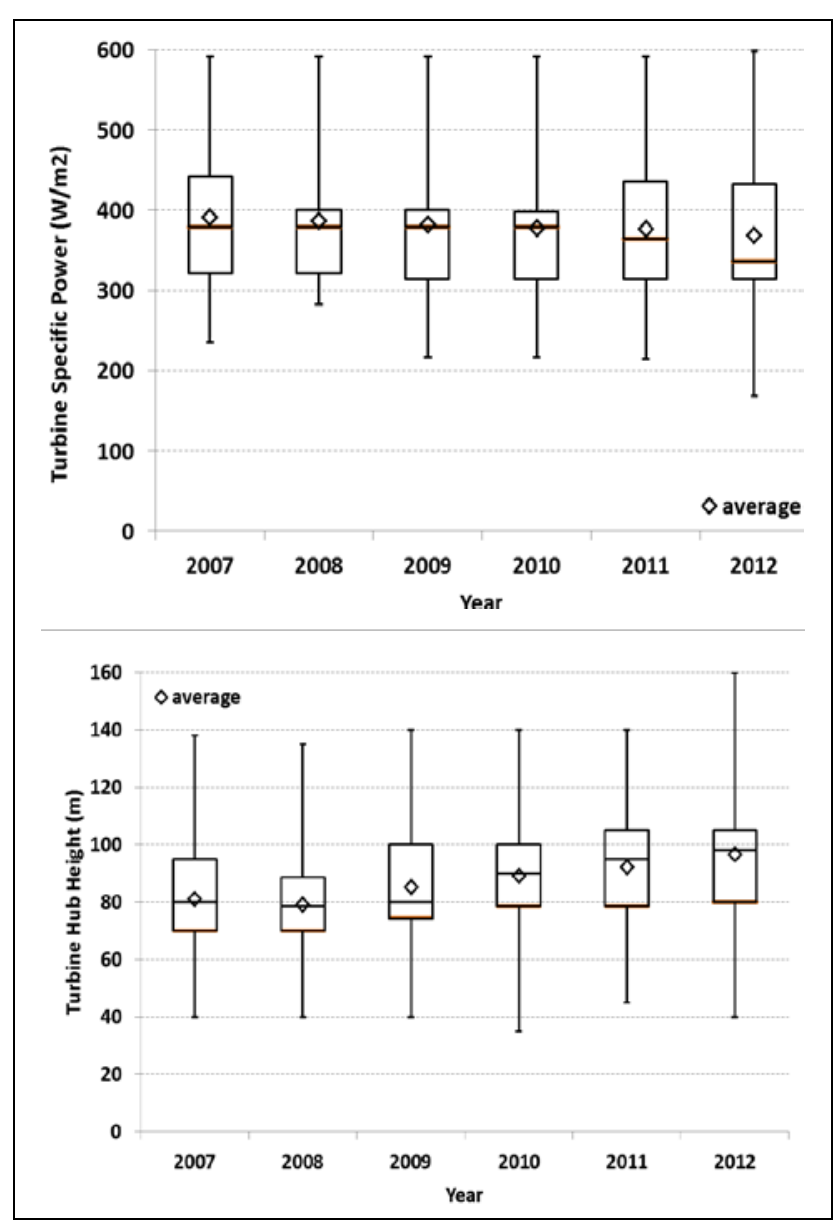

b) European Union

Figure 2. Trends in wind plant specific power and hub height from 2007 to 2012 in the United States (a) and the European Union (b)

The primary elements required to estimate LCOE include capital investment cost, expected annual energy production, expected annual operation costs, and project financing costs. The estimates presented in each chapter represent "typical" or "average" characteristics of projects 
installed in a given year. Each wind project is unique such that there is significant variation in all of the primary parameters and thereby significant variation in LCOE. However, these estimates provide an indication of general trends over the period from 2008 to 2012:

- Capital investment costs reached a peak around 2010 and have declined in most countries since then despite the increased wind turbine size. This trend is most evident in Denmark and the United States. Although Germany, Ireland and Norway do not demonstrate this decline in 2012, it may be realized in the near term and is expected based on estimates for 2014 projects in Norway.

- Energy capture increases for typical wind plants are reported by all countries, particularly for good or high wind speed locations. In some cases (e.g., Germany and the United States), utilization of lower quality resource sites offsets expected increases in full load hours or capacity factor.

- Operation and maintenance costs anticipated over the life of a wind plant are not well understood, and project cost data are lacking. It is not clear whether these costs are increasing or decreasing on average.

- Project finance costs expressed as the Weighted Average Cost of Capital (WACC) ${ }^{2}$ have generally remained flat over this period in Denmark, Ireland, and Norway. Germany and the United States report reduced WACC from 2008 to 2012.

As illustrated in Figure 3, LCOE based on the above high-level trends, results in a mixed picture for the countries represented in this analysis with both increasing and decreasing LCOE values from 2008 to 2012. Each chapter describes the technology trends behind these estimates. Initial indications since 2012 suggest a trend toward lower cost of energy through 2014. Note that these LCOE estimates do not reflect any revenue or policy incentives and assume a 20 -year depreciation schedule for comparison among countries.

A variety of revenue and policy incentives are utilized in each of the countries represented in this study. Table 1 summarizes the primary mechanisms employed in 2012 and notes potential changes to be implemented in 2014 and beyond. The feed-in tariff (FIT) was the predominant support scheme for wind energy in EU Member states during the 2008-2012 period. Recently, several countries have begun phasing out FIT schemes in favor of tender schemes or market certificate schemes. The United States continues to favor a tax-based policy although it is only available for projects that began construction before year-end 2014 .

This cost of energy analysis is restricted to land-based wind plants although some trends in offshore wind turbine technology are presented where relevant. All costs are presented in both U.S. dollars (USD or \$) and euros (EUR or $€$ ) and represent currency values for the year 2012. The World Bank currency conversion rates and gross domestic product (GDP) deflators are used to convert between currencies and to convert 2008 currency values to 2012 currency values to

\footnotetext{
${ }^{2}$ After-tax, nominal WACC $=(1-$ Debt share $) *$ Return on equity + Debt share*Return on debt* $(1-$ Corporate tax rate $) ;$ After-tax, real WACC $=((1+$ nominal $\mathrm{WACC}) /(1+$ inflation rate $))-1$
} 
adjust for inflation in a manner developed by the Intergovernmental Panel on Climate Change (Krey et al., 2014).

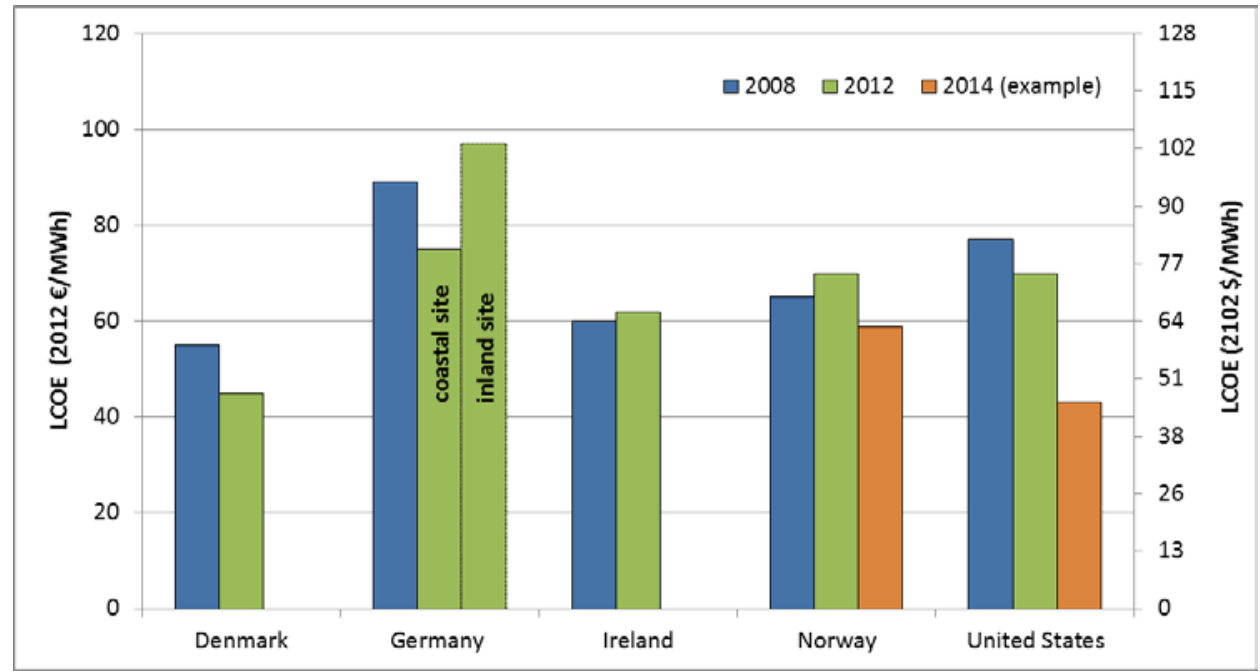

Figure 3. LCOE trend from 2008 to 2012 with some 2014 examples $^{3}$

In this document, onshore is equivalent to land-based; wind plant, wind project, and wind farm all refer to installations of multiple turbines; each country represents wind projects that are typical for installations in that country.

Table 1. Primary Revenue and Policy Incentives for Wind Projects in 2012

\begin{tabular}{|c|c|c|c|c|c|}
\hline Country & $\begin{array}{l}\text { Market } \\
\text { Price } \\
\text { Electricity }\end{array}$ & $\begin{array}{l}\text { Feed-in } \\
\text { Tariff (FIT) } \\
\text { or Feed-in } \\
\text { Premium } \\
\text { (FIP) }\end{array}$ & $\begin{array}{l}\text { Upfront } \\
\text { Capital or } \\
\text { Production- } \\
\text { Based } \\
\text { Incentive }\end{array}$ & $\begin{array}{l}\text { Accelerated } \\
\text { Depreciation }\end{array}$ & $\begin{array}{l}\text { Significant Changes for } 2014 \\
\text { and Beyond }\end{array}$ \\
\hline Denmark & $X$ & $\mathrm{X}$ & & $X$ & \\
\hline Germany & & $x$ & & $x$ & $\begin{array}{l}\text { FIT replaced with FIP and market } \\
\text { price electricity since August } 2014\end{array}$ \\
\hline Ireland & $X$ & $x$ & & & \\
\hline Norway & $x$ & & $x$ & & $\begin{array}{l}\text { Upfront capital subsidy replaced with } \\
\text { electricity market certificates in } \\
\text { combined Sweden/Norway certificate } \\
\text { market }\end{array}$ \\
\hline $\begin{array}{l}\text { United } \\
\text { States }\end{array}$ & $x$ & & $X$ & $x$ & $\begin{array}{l}\text { Production Tax Credit expired Dec. } \\
31,2014 \text { and not available for } \\
\text { projects beginning construction after } \\
2014 \text {. }\end{array}$ \\
\hline
\end{tabular}

\footnotetext{
${ }^{3}$ The LCOE estimate for Denmark is based on a wind project where grid connection costs are socialized; the estimate for Germany in 2008 represents a good average wind site rather than distinguishing between coastal or inland sites; the 2014 estimate for Norway represents wind plant technology anticipated for installation in 2014 and beyond; the 2014 estimate for the United States is an example of wind project characteristics associated with very low prices contracted in 2012-2013 for projects in the interior region of the country with relatively high annual average wind speed.
} 


\section{Chapter 1. Wind Energy Development in Denmark}

Author: Aisma Vitina (Ea Energy Analyses)

This chapter should be cited as: Vitina, A. (2015). "Wind Energy Development in Denmark," Chapter 1. Hand, M. M., ed., IEA Wind Task 26 - Wind Technology, Cost, and Performance Trends in Denmark, Germany, Ireland, Norway, the European Union, and the United States: 2007-2012. NREL/TP-6A20-64332. Golden, CO: National Renewable Energy Laboratory. pp. 16-47.

\section{Domestic Wind Energy Capacity, Production, and Targets}

Total installed wind capacity in Denmark at the end of 2012 was 4,163 megawatts (MW) $(3,241$ MW land-based and $922 \mathrm{MW}$ offshore). This is an increase of 5.3\% compared to the installed capacity at the end of 2011, and a $31.6 \%$ increase compared to the installed capacity in 2008 . In 2012, $224 \mathrm{MW}$ of turbine capacity was installed and turbines totaling $13 \mathrm{MW}$ were decommissioned. The cumulative installed wind power capacity at the end of 2013 reached 4,810 MW, comprised of 3,539 MW land-based and 1,271 MW offshore, respectively.

During the period from 2008 to 2012, four offshore wind plants were commissioned (Horns Rev II with 209 MW, Rødsand II with 207 MW, and Sprogø and Avedøre Holme with 21 MW and $11 \mathrm{MW}$, respectively) and one was under construction. The construction of the Anholt wind plant started in the beginning of 2012, and the $400 \mathrm{MW}$ project (111 Siemens SWT 3.6-120 turbines) was inaugurated in September 2013. The largest rated turbine to be installed by the end of 2012 was the $6 \mathrm{MW}$ Siemens SWT 6.0-154 at the Østerild test site. (A prototype of the $8 \mathrm{MW}$ Vestas V164-8.0 MW turbine was successfully put into operation in the beginning of 2014 at the Østerild test site.)

The new feed-in premium (FIP) introduced in 2008 renewed interest in land-based-wind-energy project development in Denmark following a period of inactivity from 2003 to 2007 caused by a significant reduction in the financial support program (Schwabe et al., 2011).

In 2012, wind power production in Denmark supplied nearly 30\% of total electricity consumption, a significant increase from the $19 \%$ share in 2008 . This proportion further increased to $32.5 \%$ in 2013 , and reached $39 \%$ in 2014 .

The Danish Energy Agreement as of March 22, 2012 (Folketinget, 2012) prescribes an expansion of Denmark's offshore wind capacity by an additional 1,500 MW by 2020 (Horns Rev 3 with $400 \mathrm{MW}$ in the North Sea and Kriegers Flak with $600 \mathrm{MW}$ in Baltic Sea, $450 \mathrm{MW}$ of near-shore capacity, and $50 \mathrm{MW}$ of near-shore test turbines).

The commitments expressed in the Danish Energy Agreement 2012 have been amended as of the launch of the Growth Plan 2014 on June 17, 2014 (Danish Ministry of Finance, 2014). The time frame for commissioning the Kriegers Flak offshore wind plant has been increased by two years (now due in $2022^{4}$ ), and the capacity of the near-shore wind plants to be tendered has been

\footnotetext{
${ }^{4}$ According to the installation schedule as per the Danish Public Service Obligation projections (Danish Energy Agency, 2014), $400 \mathrm{MW}$ of Kriegers Flak would be installed by 2020. This is the assumption used in estimating the projected offshore capacity for 2020 in this report.
} 
reduced by $100 \mathrm{MW}$. At the same time, the Danish Energy Agency accounts for the possibility of developing offshore projects within the 'open door' policy framework; i.e., under the standard land-based wind support scheme. An additional $150 \mathrm{MW}$ of offshore capacity is expected to be available by 2020 under this scheme (Danish Energy Agency, 2014).

Projections of land-based wind capacity development are less certain due to their dependence on the initiatives of private developers, municipal planning, and project approval. The analysis done by the Danish Energy Agency projects a net addition of $500 \mathrm{MW}$ to land-based capacity by 2020 (1,800 MW of new capacity installed and 1,300 MW of the existing capacity decommissioned). ${ }^{5}$

Upon completion of these plans (accounting for the amendments brought about by the Growth Plan 2014), the Danish offshore wind capacity will have increased by over $150 \%$ in 2020 compared to 2012 (Land-based capacity will only increase by $15 \%$, albeit from a much higher base).

The long-term goal of energy policies is $100 \%$ renewable energy in Denmark by 2050. Interim goals to a fossil-free economy entail $100 \%$ renewable energy-based power and heating sectors by 2035 and full phase-out of coal and heating oil by 2030.

There are, however, no politically agreed targets for wind capacity specifically in Denmark beyond 2020. The central analysis assumptions used by the national transmission system operator (TSO), Energinet.dk, are provided in this report to project long-term capacity. Further development of offshore capacity is projected to increase to $1,400 \mathrm{MW}$ by $2030,{ }^{6}$ combined with a very modest net growth in the land-based capacity of $250 \mathrm{MW}$ (Energinet.dk, 2014).

Figure 1-1 illustrates the cumulative and annual installations in Denmark until 2012, as well as projections for 2020 and $2030^{7}$.

Table 1-1 shows the cumulative wind capacity in gigawatts (GW) currently installed in Denmark, as well as future projections for 2020 and 2030. Table 1-2 shows annual additions to capacity in megawatts (MW).

The following overview and analysis will focus on land-based wind developments in Denmark over the period 2008 to 2012 (there were no utility-scale, land-based turbines installed in Denmark in 2007, and at the time of commencing this analysis, 2012 was the latest year for which complete data sets were available). Where possible, updates for more recent years have been provided (please see section Perspective Beyond 2012).

\footnotetext{
${ }^{5}$ Public Service Obligation expenditure projections analysis by the Danish Energy Agency (Danish Energy Agency, 2014) projects land-based wind capacity to be 3,694 MW in Denmark in 2020 (the estimate used in this report). This is based on the assumptions that the municipal planning-approved projects will be developed in 2014 and 2015; half of the known but not yet municipal planning-approved projects will be developed in 2014 and 2015; existing turbines will be decommissioned after a 22.5-year lifetime; half of the decommissioned turbines will be repowered within one year's period, yielding a higher capacity factor (3,000 full-load hours); and $50 \mathrm{MW}$ of new capacity (not related to decommissioning) will be developed annually.

${ }^{6}$ Adjusted for the 100-MW reduction in near-shore capacity and for the additional $150 \mathrm{MW}$ of 'open door' policy projects

${ }^{7}$ Based on data from Energistatistik 2013 (Danish Energy Agency, 2013)
} 


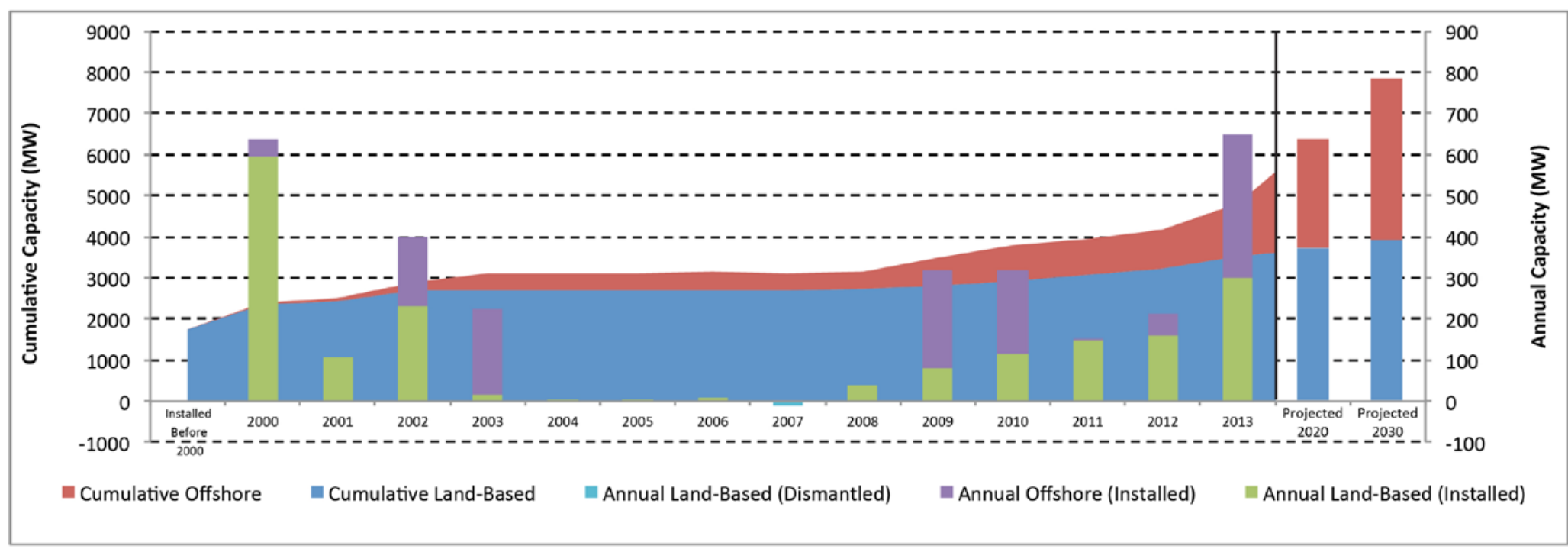

Figure 1-1. Cumulative and annual wind installations in Denmark 
Table 1-1. Cumulative and Annual Capacity Installed in Denmark

\begin{tabular}{|llllllllllllllll|} 
& $<2005$ & 2005 & 2006 & 2007 & 2008 & 2009 & 2010 & 2011 & 2012 & 2013 & 2014 & $\begin{array}{l}\text { Projected } \\
2020\end{array}$ & $\begin{array}{l}\text { Projected } \\
2030\end{array}$ \\
\hline Onshore & 2.7 & 2.7 & 2.7 & 2.7 & 2.7 & 2.8 & 2.9 & 3.1 & 3.2 & 3.5 & 3.6 & 3.7 & 4.0 & \\
\hline Offshore & 0.4 & 0.4 & 0.4 & 0.4 & 0.4 & 0.7 & 0.9 & 0.9 & 0.9 & 1.3 & 1.3 & 2.6 & 3.8 & \\
\hline
\end{tabular}

Table 1-2. Annual Capacity (MW) Additions Installed in Denmark

\begin{tabular}{|rrrrrrrrrrrrrrrr|r|r|} 
& 2000 & 2001 & 2002 & 2003 & 2004 & 2005 & 2006 & 2007 & 2008 & 2009 & 2010 & 2011 & 2012 & 2013 & 2014 \\
\hline Onshore & 597 & 107 & 233 & 16 & 4 & 4 & 8 & -11 & 39 & 82 & 113 & 147 & 160 & 298 & 75 \\
\hline Offshore & 40 & 0 & 164 & 209 & 0 & 0 & 0 & 0 & 0 & 238 & 207 & 4 & 50 & 349 & 0 \\
\hline
\end{tabular}

\section{Revenue and Policy Incentives}

The revenue and policy incentives have not changed in the period from 2008 to 2012.

According to the wind-power project support scheme introduced by the renewable energy law as of 2008, all new land-based wind-power projects and 'open door' offshore projects are to receive a nominal feed-in premium (FIP) of Danish krone (DKK) 0.25/kWh (€0.034/kilowatt-hour $[\mathrm{kWh}]$ or $\$ 0.043 / \mathrm{kWh}$ ) above and beyond the spot market price for the first 22,000 full-load hours. ${ }^{8}$ After the equivalent of 22,000 full-load hours has been generated, the project must rely on market price for power as its revenue source (Danish Energy Agency, 2015).

There is, however, an additional subsidy of DKK $0.0237 / \mathrm{kWh}(€ 0.0032 / \mathrm{kWh}$ or $\$ 0.004 / \mathrm{kWh})$ for the technical lifetime of the wind power project to cover balancing costs (Energinet.dk, 2015).

In addition, wind-power projects in Denmark benefit from wind turbine eligibility for accelerated depreciation rules. In the 2008-2012 period, wind turbines could be depreciated by $25 \%$ of their respective residual value annually. As of January $1^{\text {st }} 2013$, the rate has been decreased to $15 \%$ (Skatteministeriet, 2014).

The repowering subsidy scheme ${ }^{9}$ expired as of December 15,2011 . The repowering scheme entitled the wind-power project owner to an additional subsidy when replacing older and smaller wind turbines (under 450 kilowatts [kW]) with newer and more efficient turbines. The total capacity that could be decommissioned under the repowering scheme was $175 \mathrm{MW}$ (Danish Energy Agency, 2012). At the end of 2011, 146 new wind turbines (with a total capacity of 348 MW) had been installed fully or partially under the repowering scheme. Almost $50 \%$ of the landbased wind turbines installed from 2005 to the end of 2011 were a part of the repowering scheme. In capacity terms (MW), this proportion was almost 60\% (Danish Wind Turbine Owners' Association, 2012).

\footnotetext{
${ }^{8}$ See the Denmark country chapter in Schwabe et al. (2011) for examples and incentive analysis of the support scheme.

${ }^{9}$ See the Denmark country chapter in Schwabe et al. (2011) for more details on the repowering subsidy scheme.
} 
Repowering has also continued after the expiration of the repowering subsidy scheme. In some cases, removal of older turbines is a precondition for receiving the planning approval.

The Energy Agreement (Energiforliget) introduced along with the Promotion of Renewable Energy Act (VE-loven) as of January 1st, 2009, stipulates the following regulations (Danish Energy Agency, 2014):

1. Local citizens' option to purchase wind power project shares (The developer of a wind power project has a duty to offer at least $20 \%$ of the shares in the wind turbine to those with an option to purchase.)

2. Loss of value to real property due to the erection of wind turbines (The developer of a wind turbine has a duty to pay compensation for loss of value of real property following the installation of the wind turbine; the size of the loss of value is determined by the Valuation Commission.)

3. Green scheme to enhance local scenic and recreational values (Grant subsidies to municipalities for initiatives undertaken to promote local acceptance of the installation of new land-based wind turbines connected to a grid at an amount corresponding to DKK øre 0.4 (0.05C EUR; 0.07C USD) per kWh for 22,000 full-load hours for each wind turbine.)

4. Guarantee fund for loans by local wind turbine owners' associations to finance preliminary investigations, prepare applications, etc.

\section{Wind Energy Project Trends in Denmark since 2008}

The following section describes the wind energy trends in Denmark in the period 2008-2012.

The data hereby presented are based on capacity-weighted averages for projects planned (for cost parameters) or commissioned (for technical parameters) in the respective years reviewed. Data sources include:

1. The 'Core data registry' (Stamdataregister) published by the Danish Energy Agency based on monthly data reports from the Danish TSO, Energinet.dk, and the grid companies, detailing the characteristics and production data of each grid-connected wind turbine (Danish Energy Agency, 2014).

2. The 'Wind turbine project overview' (Vindmølleprojektoversigt) database hosted and updated by the Danish TSO, Energinet.dk, according to the requirements stipulated in the Promotion of Renewable Energy Act enacted on January 1st, 2009. The database (as of May 2014) contains data on grid-connection projects in the period March 2010December 2012 (Energinet.dk, 2014 ). These data, along with data provided by the Danish Nature Agency (Naturstyrelsen), are used to create the wind project size overview.

3. The wind energy project-share purchase information documents made public in accordance with the requirements of the 'Share purchase right' (Køberetsordning) regulation, detailing top-level, cost-price information of the project. It should be noted that the investment cost information from the Køberetsordning documents hereby 
presented is representative of the year when the investment decision was made (and share purchase made available to the local residents), not the year of installation.

For the purpose this study, the sample of the projects in question is delimited to those comprised

of 'utility-scale' wind turbines (unless explicitly stated otherwise). Utility-scale wind turbines are hereby defined as turbines with nameplate capacity equal or larger than $1 \mathrm{MW}$. It should also be noted that only three turbines (750-kW capacity each) were installed in 2007. Hence, due to the non-representative sample (and also the 1-MW or larger turbine capacity threshold), the data for 2007 generally are not reflected in the study. Appendix 1-A contains a definition and sample sizes for the graphs presented.

All cost data are in EUR (and USD in parenthesis) in real 2012 currency terms unless stated otherwise. The Intergovernmental Panel on Climate Change (IPCC) methodology is used for currency and annual inflation adjustments.

\section{Project Features}

The size of land-based wind projects has remained largely unchanged throughout the period 2008 to 2012. The average size of a wind energy project in Denmark in 2012 was in the range of three to six turbines.

Wind power projects in Denmark are generally small clusters ranging from 3 to 12 turbines. Planning guidelines recommend that wind power projects should be erected in clusters of at least three turbines arranged in a straight line or a gentle curve to avoid the prevalence of single turbines scattered throughout the landscape and reduce visual impact. There are a few examples of larger land-based wind plants in Denmark, but compared to projects in, for example, Spain or the United States, they are very small (Schwabe et al., 2011). As of 2013, the largest project is about 20 turbines with a total capacity of just over $70 \mathrm{MW}$.

Figure 1-2 illustrates the wind power plant size trends in the period 2008 to 2012. A box and whiskers format is used to represent the projects or turbines that achieved commercial operation in a given year including the median (horizontal line), average (diamond), $25^{\text {th }}$ to $75^{\text {th }}$ percentile (box), and minimum and maximum (whiskers).

The prevailing support scheme in Denmark from 2008 to 2012 (based on 22,000 full-load hours) favored turbines with large-rated power (Schwabe at al., 2011). Not surprisingly then, the rated capacity of turbines installed in Denmark from 2008 to 2012 is very high on average and increased throughout the period. 


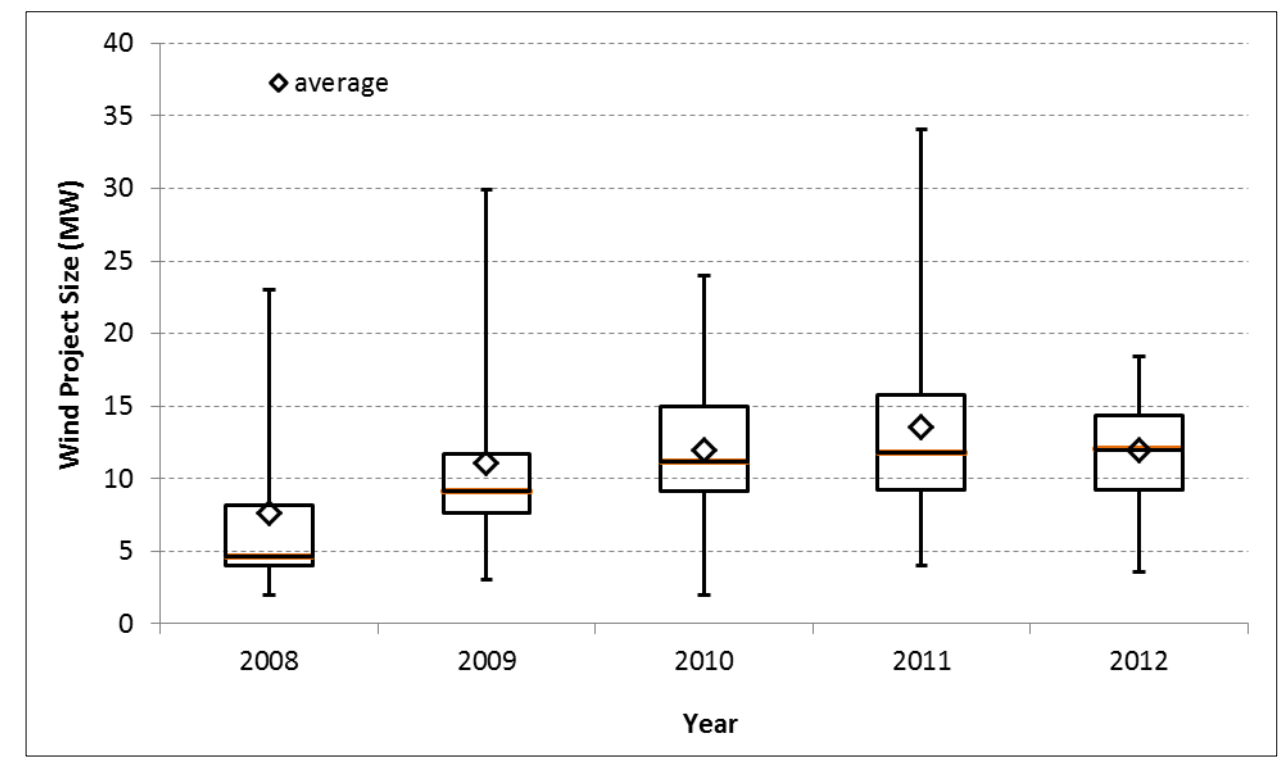

Figure 1-2. Wind project size trends ${ }^{10}$ from 2008 to 2012

The predominant capacity rating of the turbines in 2012 was $3 \mathrm{MW}$, a considerable increase compared to the average of 2-2.3-MW turbine nameplate capacity in 2008 (Figure 1-3). The most common turbine installed in 2012 was a 3-MW generator, with a hub height of 89.5 meters (m) and a rotor diameter of $101 \mathrm{~m}$.

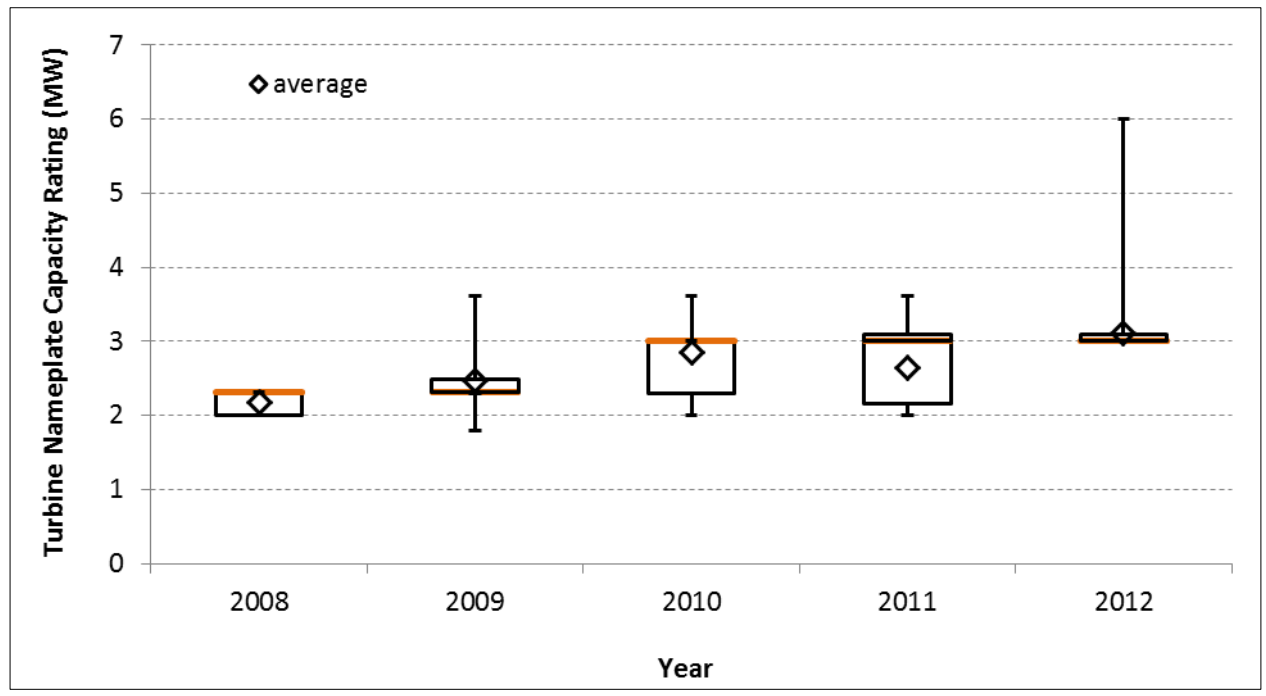

Figure 1-3. Wind turbine nameplate capacity rating trends from 2008 to 2012

Compared to 2008, there was also an increase in rotor diameter (Figure 1-4), a development in line with the increasing average turbine capacity.

\footnotetext{
${ }^{10}$ Historic project size data has been provided by the Danish Nature Agency (Naturstyrelsen).
} 


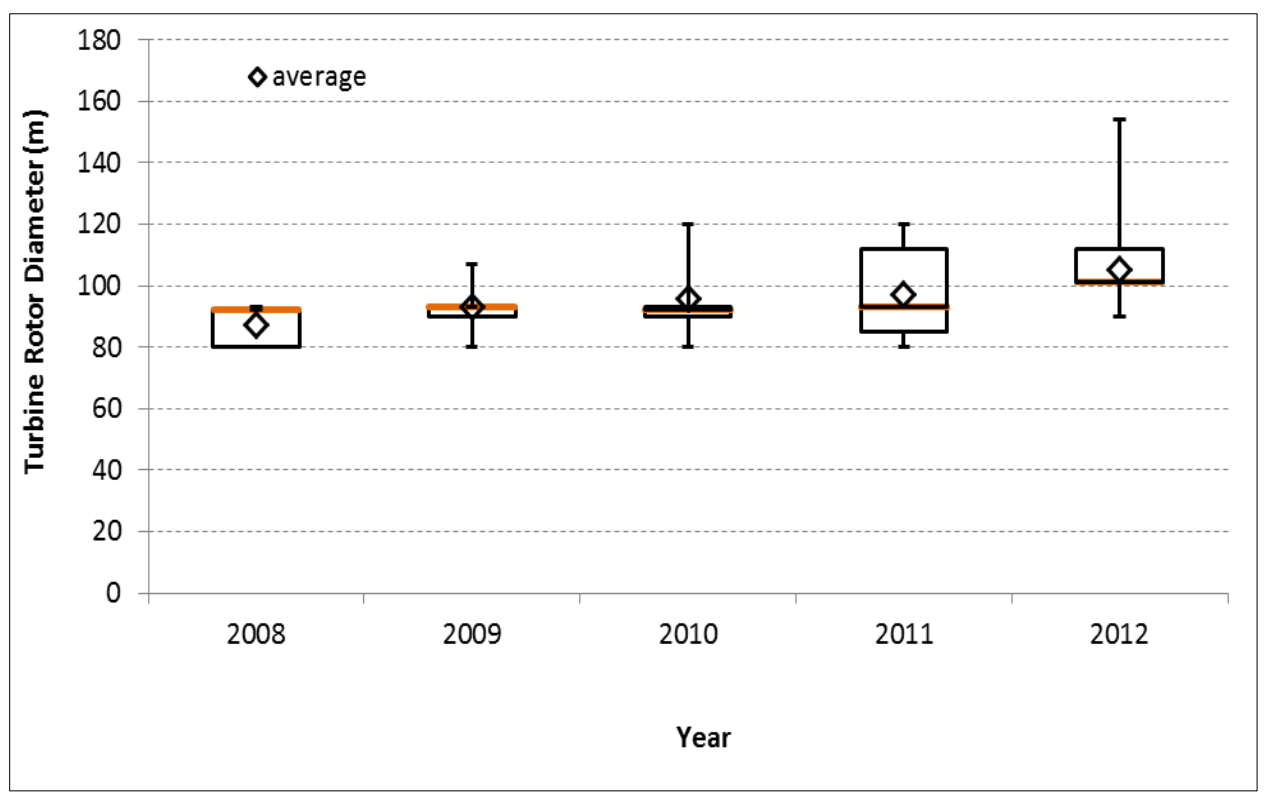

Figure 1-4. Wind turbine rotor diameter trends from 2008 to 2012

The same pattern occurs for turbine hub heights, as illustrated by Figure 1-5.

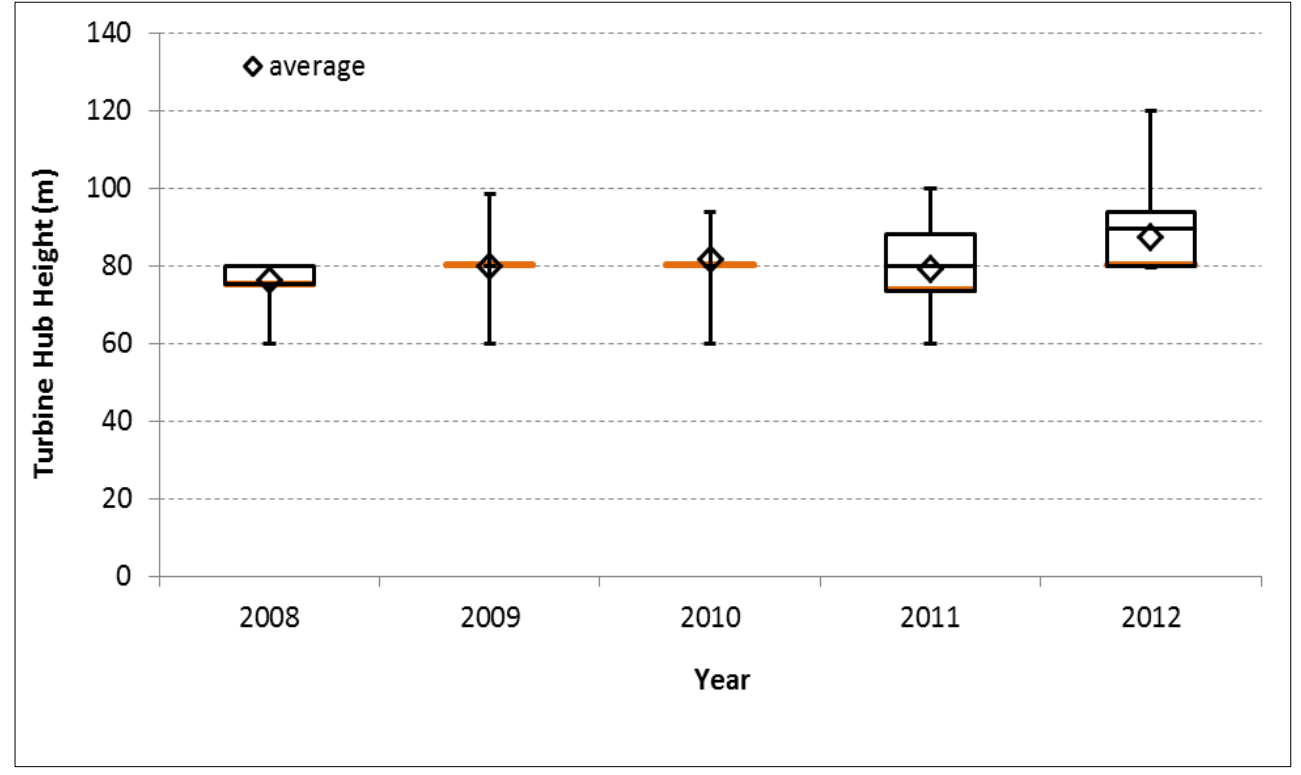

Figure 1-5. Wind turbine hub height trends from 2008 to 2012

There has been a negative trend in terms of turbine-specific power in Denmark starting around 2000 and leveling out around 2008 (the average specific power for newly installed turbines in Denmark was the same in 2008 as in 2012, with moderate fluctuations in between). This indicates that the rotor-swept area has been increasing faster than turbine capacity for a period of time; and turbines with lower specific power generally have a higher capacity factor, as more energy is captured by the rotors (at below rated-output wind speeds). 
Data from years 2008-2012, however, show that the decline in the average turbine specific power stopped; turbine specific power stayed relatively constant for that period (Figure 1-6), coinciding with the increasing homogeneity of the dimensions of the newly installed wind turbines in Denmark. As stated earlier, it should also be noted that the prevailing support scheme in the period reviewed favored turbines with large generators (and did not directly stipulate increase in rotor size). However, the support scheme reform as of January 1, 2014 is expected to alter this development.

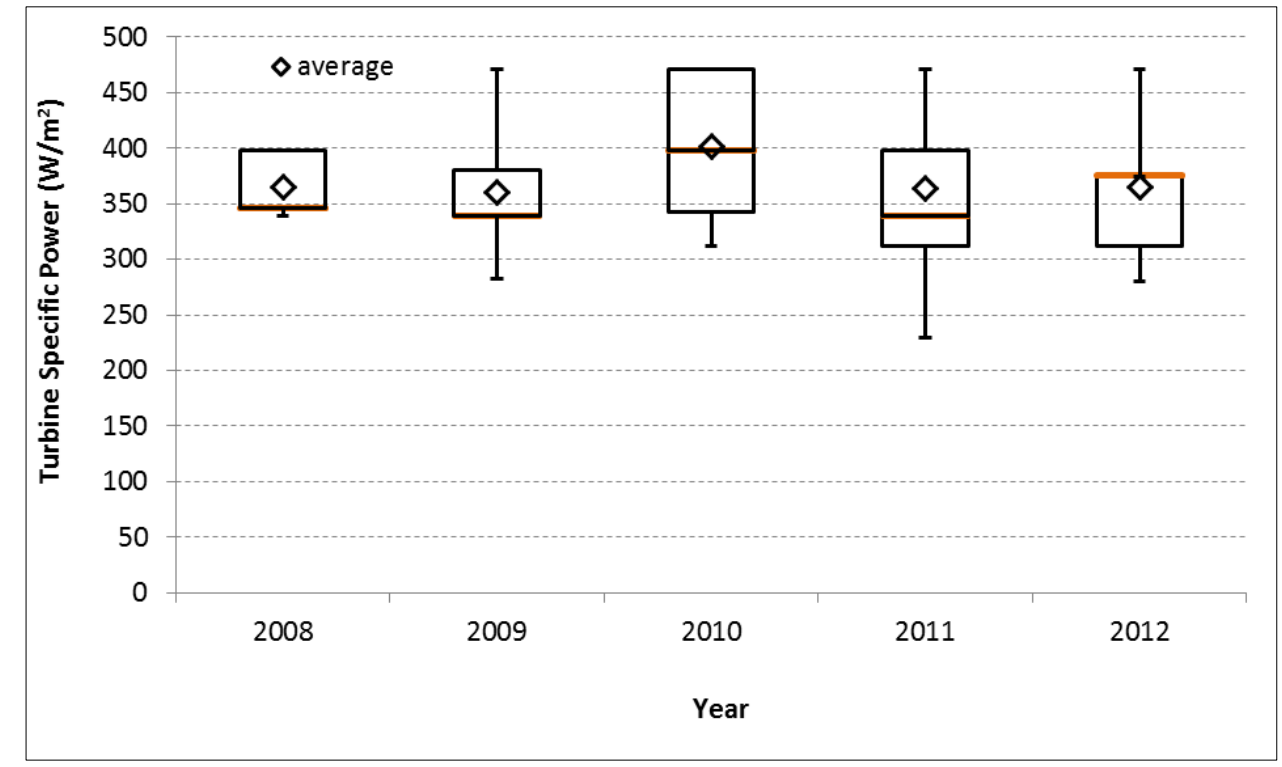

Figure 1-6. Wind turbine specific power for projects installed from 2008 to 2012

There has also been a development in the design parameter class of the newly installed turbines in Denmark in the period 2008 to 2012. The International Electro-Technical Commission (IEC) classification for wind turbines is based, among other things, on the average annual wind speed at the hub height for which the turbine is designed. A higher IEC class means that the turbine is designed for higher average annual wind speed and extreme wind gust conditions (e.g., Class I turbines are designed for higher wind speeds than Class II turbines and so forth).

Figure 1-7 illustrates the decreasing share of Class I turbines among newly installed projects in Denmark through 2012. Note that the availability of Class II and Class III turbines in the market was limited in the past.

Industry sources suggest that the prevalent support scheme in Denmark from 2008 to 2012 encouraged the use of higher class wind turbines even though the conditions of a particular site would not necessarily warrant it (this incentive changed with the support scheme reform as of January 1, 2014). 


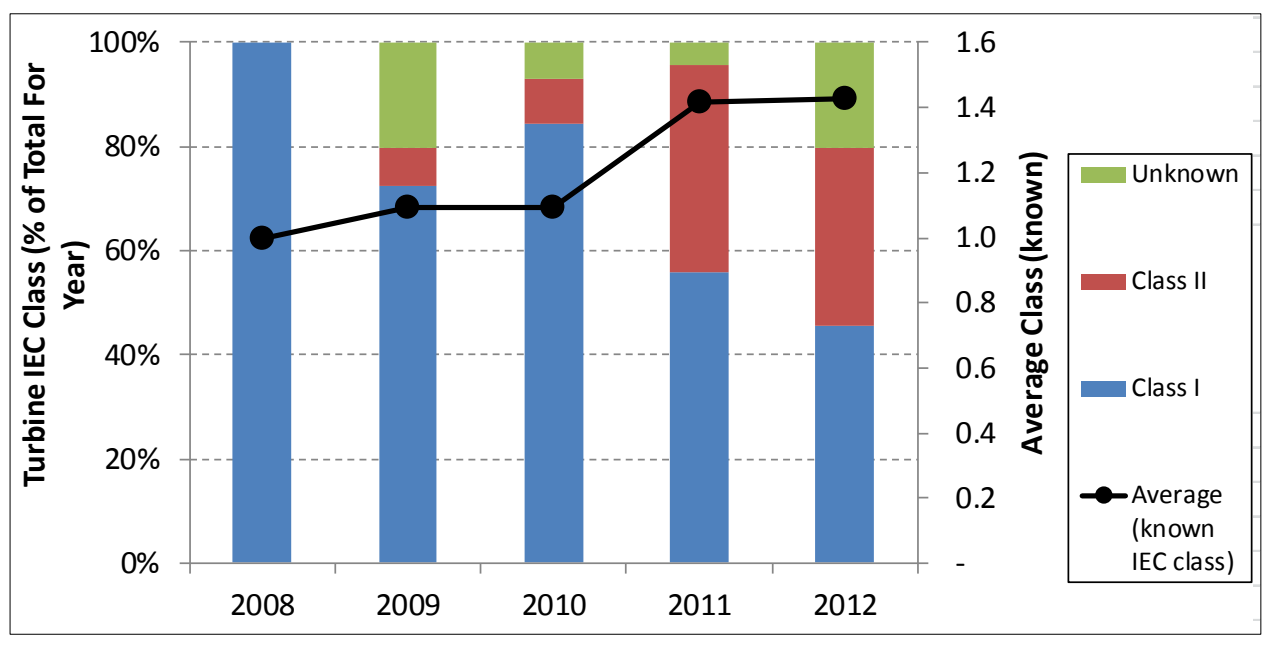

Figure 1-7. Proportion of turbines by IEC class ${ }^{11}$ installed from 2008 to 2012

\section{Project Performance}

The prevailing wind direction in Denmark is westerly, which makes sites along the North Sea coast the most attractive for wind turbines, and wind resources generally decline as one moves eastwards (Schwabe et al., 2011). For new 80-94-m hub height projects near the West coast, wind speeds of 7.5-9 m/second (s) are typical. (The large deviation is due to the high sensitivity to the distance from the coast.). For inland sites, wind speeds of $6.5-7 \mathrm{~m} / \mathrm{s}$ are typical for new 80-94-m hub height projects. There is not much variation in the inland site wind speeds due to the large hub heights.

In the period 2008-2012, the average wind resource at the sites stayed relatively unchanged, with a slight decrease in 2012, as illustrated by Figure 1-8. This is explained, among other things, by increasing scarcity of available locations for wind power siting in Denmark. At the same time, it has become increasingly common for developers to repower existing, older sites (with potentially more favorable wind resource availability). The latter entails the purchase of the original turbines on the site, however, which can significantly affect investment costs.

The generation-weighted average ${ }^{13}$ number of full-load hours in 2013 , for turbines installed in 2008 , is 2,866 . The 2013 wind resource in Denmark was $93.4 \%$ of a normal year ${ }^{14}$, indicating that the lifetime average number of full-load hours for turbines installed in 2008 is expected to be approximately 3,068. The average capacity factor of newly installed wind turbines in Denmark has been relatively high and very stable, exhibiting only slight variability in the period 20082012. The generation-weighted average full-load hours of projects installed in 2012 (based on

\footnotetext{
${ }^{11}$ Data source: 'Core data registry' (Stamdataregister) published by the Danish Energy Agency; information on the IEC class of turbine models provided by Vestas (covering all known manufacturers/turbines in the overview)

${ }^{12}$ Based on information provided by Per Nielsen, EMD

${ }^{13}$ Generation-weighted average represents the average performance of wind projects, weighted by each project's electricity production (as opposed to its capacity, as is the approach in capacity-weighted capacity factors).

${ }^{14}$ The wind energy index in Denmark (locally and nationally) has been calculated since 1979. It is available on a monthly and annual basis and provides the wind power production coefficient in the given period relative to expected production in a 'normal' wind energy year. Wind energy indices for Denmark are available at www.vindstat.dk, and the method is described in Nielsen (2013).
} 
2013 production data) was 2,842 ; which, once indexed to account for a typical wind year, reaches 3,042 full-load hours (or a capacity factor of almost 35\%).

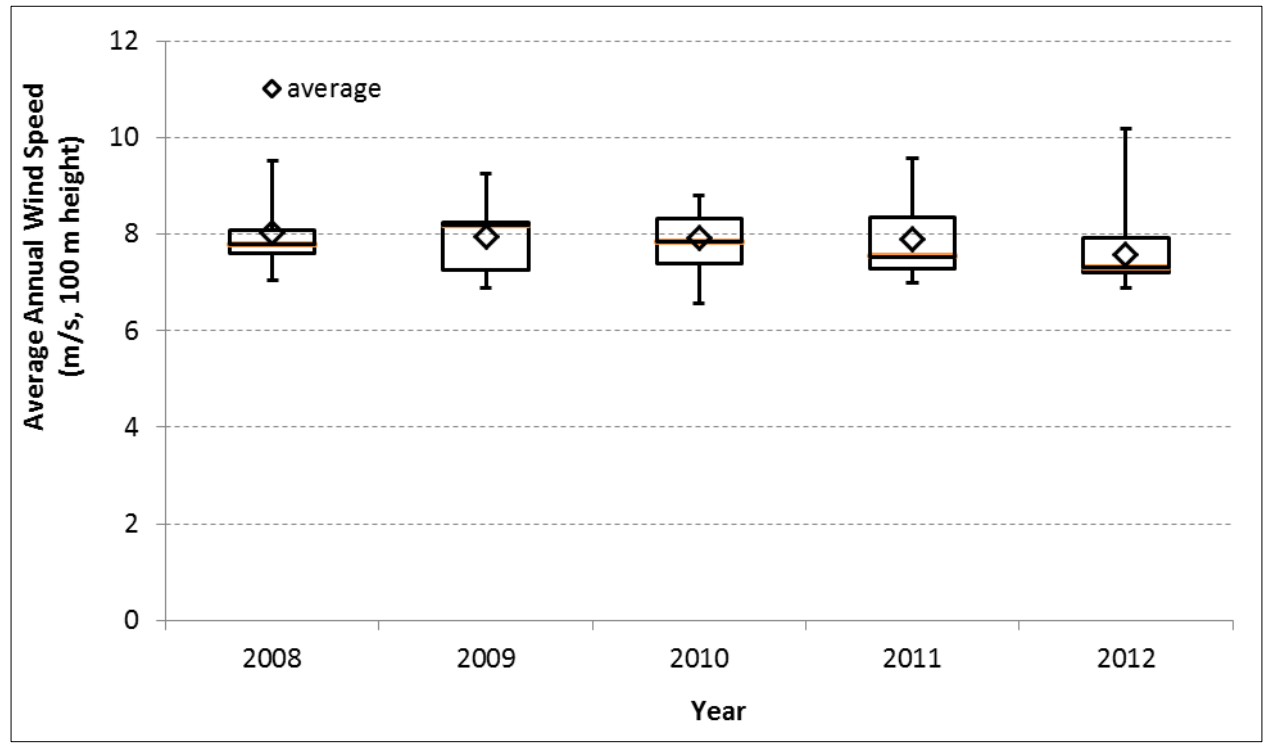

Figure 1-8. Average annual wind speed ${ }^{15}$ for projects installed from 2008 to 2012

Figure 1-9 provides an overview of full-load hours for projects installed in the period 2008-2012 and operating in 2013, indexed to a normal wind year.

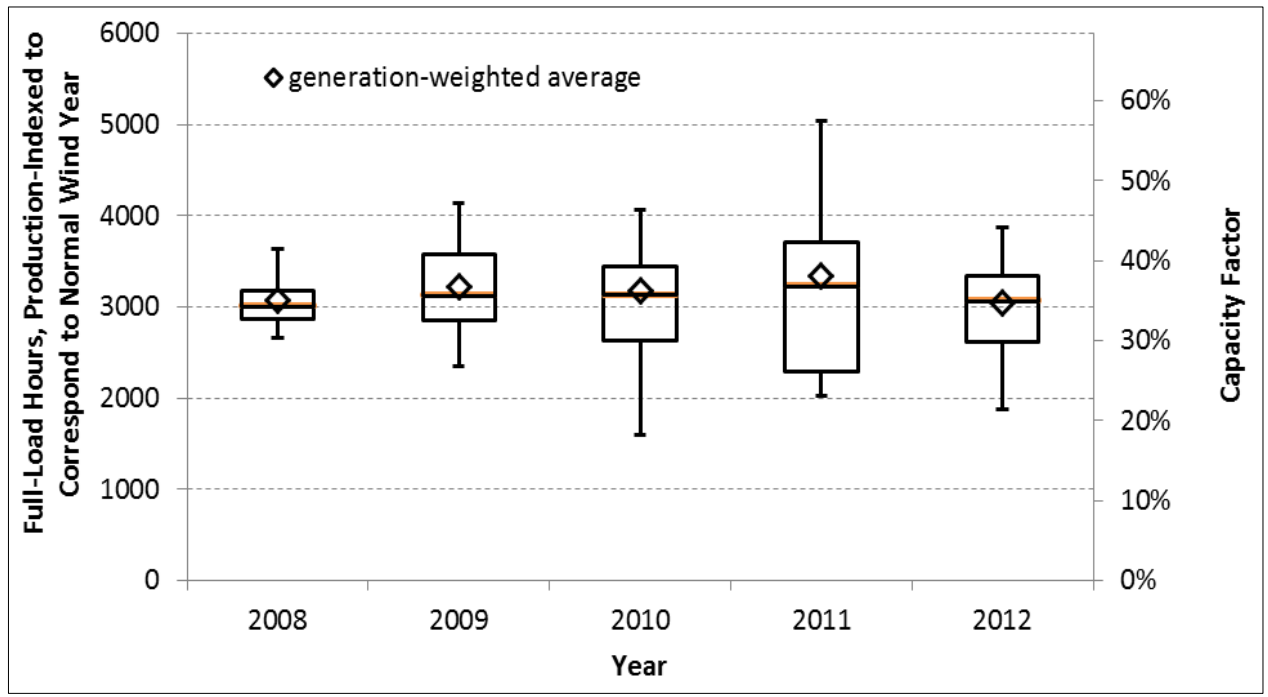

Figure 1-9. Full-load hours and capacity factor for projects installed from 2008 to 2012, operating in 2013

\footnotetext{
${ }^{15}$ Wind speed geographic information system data for Denmark was provided by the Danish Nature Agency (Naturstyrelsen). Individual turbine-level wind speed data are obtained by matching the wind speed and turbine coordinates (based on the Core Data Registry by Danish Energy Agency) at $1 \mathrm{~km}$ x $1 \mathrm{~km}$ resolution.
} 
It is important to note that the estimated full-load hours are generation-weighted and based on projects installed in the years reviewed that operated during 2013 - and not on the total Danish wind resource potential. In addition, the capacity factors have been normalized in accordance with the wind energy index, 93.4\% for 2013 (Danish Wind Turbine Owners' Association, 2014). This means, for example, that the full-load hours for projects installed in 2012 that are based on the 2013 production data are multiplied by 100/93.4 in order to provide a representative capacity factor corresponding to normal wind year conditions).

\section{Investment Costs}

Typical project investment costs ranged from $€ 1,158 /$ kilowatt $(\mathrm{kW})(\$ 1,488 / \mathrm{kW})$ to $€ 1,913 / \mathrm{kW}$ $(\$ 2,458 / \mathrm{kW})$ in 2008 with an average of $€ 1,475 / \mathrm{kW}(\$ 1,895 / \mathrm{kW})$. The prices peaked in 2008 and have gone down thereafter. Note that grid connection costs are included to a limited extent (i.e., from the turbine to the coupling, the only costs paid by the developer). All other grid connection costs are socialized and not hereby represented.

Loss-of-value compensation payments and expenditures related to repurchasing old turbines are also excluded from the sample to ensure consistency with the 2008 data (the loss of value for real property regulation began in January 2009). Loss-of-value compensation payments and the related additional administration expenses are estimated not to exceed $1 \%$ of the total wind power project costs on average during the 2009-2012 period $^{16}$ (Jensen \& Olsen, 2013).

The capacity-weighted average investment costs in Denmark in 2012 amounted to $€ 1,273 / \mathrm{kW}$ $(\$ 1,635 / \mathrm{kW})$, ranging from $€ 920 / \mathrm{kW}(\$ 1,181 / \mathrm{kW})$ to $€ 1,505 / \mathrm{kW}(\$ 1,934 / \mathrm{kW})$. Following the price decreases 2008 onwards, the average installation costs appear to be leveling out in 2011 and 2012.

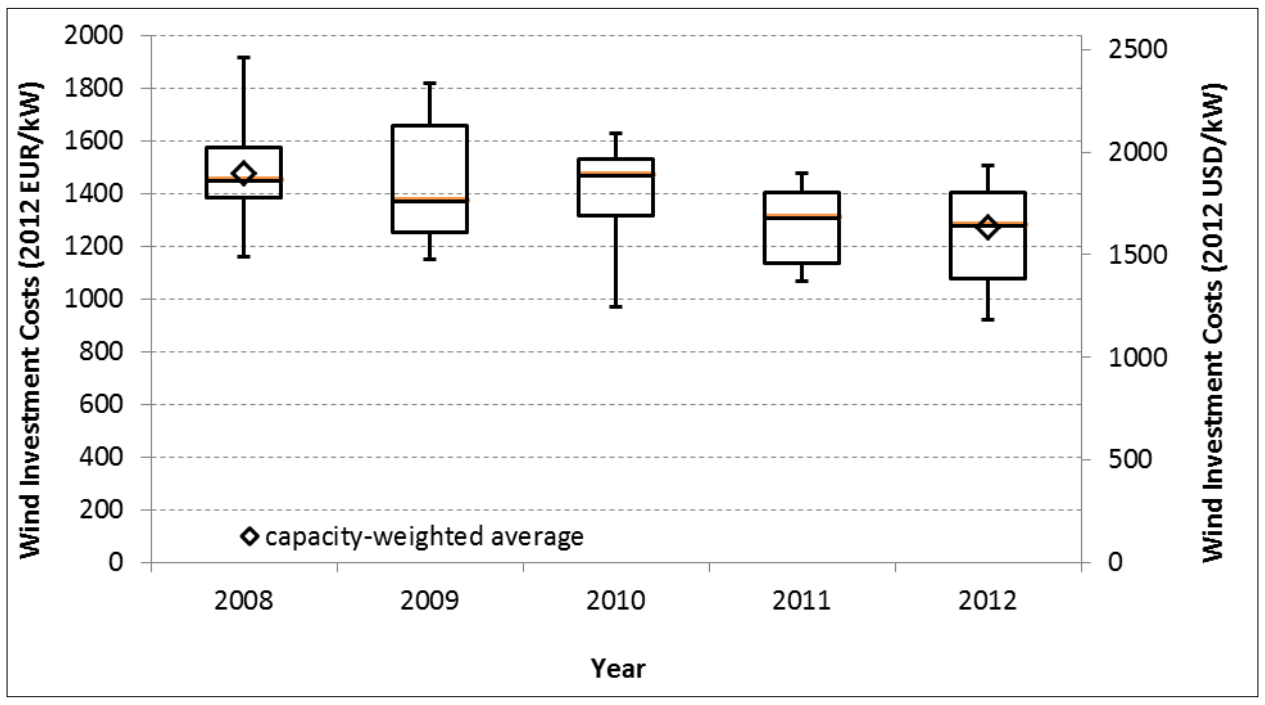

Figure 1-10. Investment costs for wind projects installed from 2008 to 2012

\footnotetext{
${ }^{16}$ Based on the rulings of the Valuation Commission on 527 loss-of-value applications by October 31, 2012
} 


\section{Operations and Maintenance Costs}

The expected lifetime costs for O\&M (consisting of insurance, repair, service agreement, and land rent/administration costs) for a wind project built in 2008 were reported to be around $€ 12.8 /$ megawatt-hour (MWh) (\$16.4/MWh) (Nielsen et al, 2010).

The components of O\&M costs for a typical wind power project established 2012 (or later) have been estimated as follows (Larsen, 2014):

- Producer service agreement for 20 years: 7-8 øre/kilowatt-hour (kWh) (€9.4-10.7/MWh; $\$ 12.1-13.8 / \mathrm{MWh})$

- Insurance: 1 øre/kWh (€1.3/MWh; $\$ 1.7 / \mathrm{MWh})$

- Administration: 0.5 øre/kWh (€0.7/MWh; \$0.9/MWh)

- Miscellaneous maintenance expenses not included in the service agreement: $0.5 \varnothing \mathrm{re} / \mathrm{kWh}$ (€0.7/MWh; \$0.9/MWh)

- After 15 years of operation, the O\&M costs are estimated to increase by $2 \%$

The average total expected lifetime costs for projects established in 2012 are estimated at 9-10 øre/kWh or $€ 12.1-13.4 / \mathrm{MWh}(\$ 15.5-17.3 / \mathrm{MWh})$, according to the Danish Wind Turbine Owners' Association (Larsen, 2014).

Note, however, that the cost components in the O\&M costs can vary. For example, land-lease payments for wind power projects in Denmark would typically be paid up front for a period of about 5 years. More recent projects would include examples of revenue-dependent annual landlease payments amounting to, for example, $6-8 \%$ of the annual power sales. ${ }^{17}$ Other cost components that can be allocated to either the investment costs or O\&M costs include insurance and service agreements (upfront payment for several years in advance, annual payments, or a combination thereof). Due to the data availability limitations, it has not always been possible to ensure consistent allocation of these cost components to either of the cost categories.

\section{Financing Costs}

Project financing with $80 \%$ annuity-based debt is typical for Denmark, and this financing structure has remained unchanged throughout the period 2008-2012. Industry sources suggest that the average payback time on loans to land-based wind projects is about 13 years.

Privately owned wind turbines in Denmark are generally financed with an overdraft facility. All income is placed in the overdraft facility and the wind turbine owners do not have direct access to the funds. All expenditure and payment of returns on investments must be approved by the creditor (Schwabe et al., 2011).

Interest rates for land-based wind power projects are generally low compared to many other business ventures because they are considered to have good liquidity. Wind turbines are

\footnotetext{
${ }^{17}$ Based on information provided by a representative of Ringkjøbing Landbobank, a wind power project financing institution
} 
considered low risk ventures as there are good facilities available for managing risk factors in wind power projects (Schwabe et al., 2011).

The cost of lending used in the projections for new wind energy projects in Denmark in 2012 has been very uniform at 5\% (nominal), unchanged from 2008.

Throughout the period 2008-2012, an equity rate in the range of 9 to $11 \%$ (nominal) has been typical for land-based wind power projects in Denmark. ${ }^{18}$ Compared to the historic (1983-2002) average risk premium on OMX 20 on the Danish stock exchange of $7.2 \%$, wind power projects are characterized with low risk premiums of about 5-7\% (Saabye (2003), cited in Schwabe et al. [2011]).

Table 1-3 summarizes wind power project financing terms for new projects in 2008 and 2012.

Table 1-3. Wind Energy Financing Terms in Denmark

\begin{tabular}{|l|l|c|c|}
\hline \multicolumn{2}{|l|}{} & $\mathbf{2 0 0 8}$ & $\mathbf{2 0 1 2}$ \\
\hline Return on equity & $\%$ & $11.0 \%$ & $11.0 \%$ \\
\hline Return on debt & $\%$ & $5.0 \%$ & $5.0 \%$ \\
\hline Equity share & $\%$ & $20 \%$ & $20 \%$ \\
\hline Debt share & $\%$ & $80 \%$ & $80 \%$ \\
\hline Loan duration & (years) & 13 & 13 \\
\hline Corporate tax rate & $\%$ & $25 \%$ & $25 \%$ \\
\hline FX rate & $($ DKK/€) & 7.353 & 7.44 \\
\hline FX rate & $($ USD/€) & 1.39 & 1.28 \\
\hline WACC (after-tax, nominal) & $\%$ & $5.2 \%$ & $5.2 \%$ \\
\hline
\end{tabular}

\section{Cost of Wind Energy Generation in Denmark in 2008 and 2012}

\section{Representative Wind Energy Project in 2008 and 2012}

The following section describes the characteristics of a 'typical' wind project in Denmark in 2008 and 2012. Data are based on capacity-weighted averages and the most common installed turbine types. Table 1-4 summarizes the features of wind energy projects in Denmark in 2008 and 2012.

\section{Model Input Assumptions}

To represent a typical wind power project in 2008, the model input assumptions from the earlier International Energy Agency (IEA) Wind Task 26 report (Schwabe et al., 2011) have been used. The investment costs have been updated based on a more complete dataset. The cost data for 2008 have been converted from 2008 EUR and USD values to 2012 EUR and USD values (by applying the corresponding inflation adjustments and currency exchange rates), respectively.

\footnotetext{
${ }^{18}$ Based on information provided by a representative of Ringkjøbing Landbobank and Danish Wind Turbine Owners' Association
} 
The 2012 typical project reflects the features of the wind turbine that has been the most common among installations in 2012, along with the capacity-weighted installation costs of projects planned in 2012 (as explained earlier, grid connection costs are only included to a limited extent, and loss-of-value compensation is excluded). The financing terms for 2012 come from industry representatives. ${ }^{19}$

Table 1-4. Wind Energy Project Features in Denmark

\begin{tabular}{|l|l|c|c|}
\hline \multicolumn{2}{|l|}{} & 2008 & 2012 \\
\hline Unit size & $\mathrm{MW}$ & 2.3 & 3 \\
\hline Number of turbines & $\mathrm{N}$ & 3 & 4 \\
\hline Rotor Diameter/Hub height & $\mathrm{m} / \mathrm{m}$ & $93 / 80$ & $101 / 90$ \\
\hline Annual Average Wind Speed at hub height & $\mathrm{m} / \mathrm{s}$ & 7 & 7 \\
\hline Production & (full-load hours) & 2,700 & 3,000 \\
\hline Economic life & (years) & 20 & 20 \\
\hline Investment costs & $€ / \mathrm{kW}(\$ / \mathrm{kW})$ & $1,475(1,895)$ & $1,273(1,635)$ \\
\hline O\&M costs fixed & $€ / \mathrm{kW}(\$ / \mathrm{kW})$ & - & - \\
\hline O\&M costs variable & $€ c e n t / \mathrm{kWh}(\$ c e n t / \mathrm{kWh})$ & $1.35(1.73)$ & $1.28(1.64)$ \\
\hline Decommission costs & $€ c e n t / \mathrm{kWh}(\$ c e n t / \mathrm{kWh})$ & - & - \\
\hline WACC $($ nominal/real) & $\%$ & $5.2 \% / 3.3 . \%$ & $5.2 \% / 3.3 . \%$ \\
\hline Corporate Tax Rate & $\%$ & $25 \%$ & $25 \%$ \\
\hline
\end{tabular}

In Denmark, typical wind power projects in 2012 feature larger turbines than in 2008 . The investment cost is considerably lower in 2012 than in 2008, as are O\&M costs. O\&M costs of $9.5 \varnothing \mathrm{re} / \mathrm{kWh}$ are representative ${ }^{20}$ for 2012, whereas the O\&M costs for 2008 have been adjusted upwards by 0.5 øre/kWh (in DKK 2008 currency terms) relative to the Schwabe et al. (2011) analysis equivalent to represent the additional miscellaneous expenses not included in the service agreement. $^{21}$

The financing terms have remained unchanged from 2008 to 2012. There are indications of lower return on equity and return on debt rates in the following years (e.g., for projects planned in 2014) of about $9 \%$ and $4 \%$, respectively. Real after-tax weighted average cost of capital (WACC) has been used in the LCOE calculation by applying a 1.8\% inflation rate per annum. This corresponds to the long-term consumer price inflation projection in Denmark (Finansministeriet, 2013) and is also in line with the European Central Bank's target inflation rate of below, but close to, $2 \%$ over the medium term (ECB, 2014).

The energy and policy incentives in Denmark have remained unchanged in the period 20082012 (Table 1-5), the nominal FIP rate remaining at DKK $0.25 / \mathrm{kWh}$ over the spot market price for the first 22,000 full-load hours. (The difference is due to conversion of the 2008 and 2012 nominal rates into 2012 real currency terms.)

\footnotetext{
${ }^{19}$ Based on information provided by a representative of Ringkjøbing Landbobank and Danish Wind Turbine Owners' Association

${ }^{20}$ The O\&M costs, as well as other project features, can vary greatly on an individual project basis.

${ }^{21}$ Based on feedback from the Danish Wind Turbine Owners' Association (Larsen, 2014)
} 
Table 1-5. Wind Energy Policy and Revenue Incentives in Denmark

\begin{tabular}{|c|c|c|c|}
\hline & & 2008 & 2012 \\
\hline Market price electricity & $€ /$ kWh $(\$ / k W h)$ & $0.047(0.06)$ & $0.031(0.04)$ \\
\hline FIP revenue 22 & $€ /$ kWh $(\$ / k W h)$ & $0.0396(0.051)$ & $0.0367(0.047)$ \\
\hline FIP policy period & Full-load hours & 22,000 & 22,000 \\
\hline FIP policy period & (years) & $8.15^{23}$ & 7.33 \\
\hline \multicolumn{4}{|l|}{ Upfront tax-based } \\
\hline subsidy before tax & $\%$ & N/A & N/A \\
\hline \multicolumn{4}{|l|}{ Production-based before } \\
\hline tax credits & $€ / k W h$ & N/A & N/A \\
\hline \multicolumn{4}{|l|}{ Production-based before } \\
\hline tax credit policy period & (years) & N/A & N/A \\
\hline Depreciation period & (years) & Max $25 \%$ annually & Max $25 \%$ annually \\
\hline Reactive power bonus & $€ /$ kWh & $\mathrm{N} / \mathrm{A}$ & $\mathrm{N} / \mathrm{A}$ \\
\hline Low-voltage ride-through bonus & $€ /$ kWh & N/A & N/A \\
\hline Market certificates & $€ / \mathrm{kWh}$ & N/A & $\mathrm{N} / \mathrm{A}$ \\
\hline
\end{tabular}

The average market price for electricity was substantially higher in 2008 than in 2012 . This is due to many factors, including significantly higher fossil fuel prices, $\mathrm{CO}_{2}$ prices, as well as power demand in 2008 as compared to 2012. Furthermore, there were considerable additions to the total wind and solar generation capacity in the NordPool region in the period from 2008 to 2012 , thereby increasing the supply of electricity with near-zero short-run marginal costs in 2012.

In the LCOE calculation, the future FIP revenue streams have been converted to real terms by applying the $1.8 \%$ inflation rate per annum explained earlier.

\section{LCOE, Policy Incentives, and Required Revenue}

The LCOE for the representative wind power projects in Denmark in 2008 and 2012 is estimated using the ECN cash flow model. Thereafter, the policy impact of each representative project, consisting of the combination of the prevailing $\mathrm{FIP}^{24}$ revenue and the accelerated depreciation allowances, has been estimated. Required revenue is the difference between the LCOE and the policy incentives; i.e., the minimum power market price level that enables the wind power producer to cover all costs and yield the required return on equity embedded in the WACC used in the cash flow model. Detailed description of the approach used in estimating the LCOE, policy impact, required revenue, and the financial gap is provided in Appendix 1 Methodology.

\footnotetext{
${ }^{22}$ The Deed-in-Premium (FIP) revenue scheme has remained the same (in nominal terms) from 2008 to 2012 , being comprised of a price supplement of DKK $0.25 / \mathrm{kWh}$ and an additional DKK $0.0237 / \mathrm{kWh}$ subsidy to cover balancing costs. There is, however, no inflation adjustment provision in the FIP scheme, so the subsidy was higher in real terms in 2008 than in 2012.

${ }^{23}$ In the ECN model for 2008, this is represented by applying a nine-year policy period, where the FIP revenue for the $9^{\text {th }}$ year is weighted with 0.15 . (For 2012, the 8 -year policy period and a 0.33 coefficient are used.)

${ }^{24}$ Combined with the balancing cost subsidy - yet the balancing costs and the balancing cost subsidy are assumed to cancel each other out. Hence, the balancing costs are set equal to the balancing cost subsidy in the ECN model
} 
Figure 1-11 provides an overview of the LCOE, policy impact, and required revenue values for a representative wind power project in Denmark in 2008 and 2012.

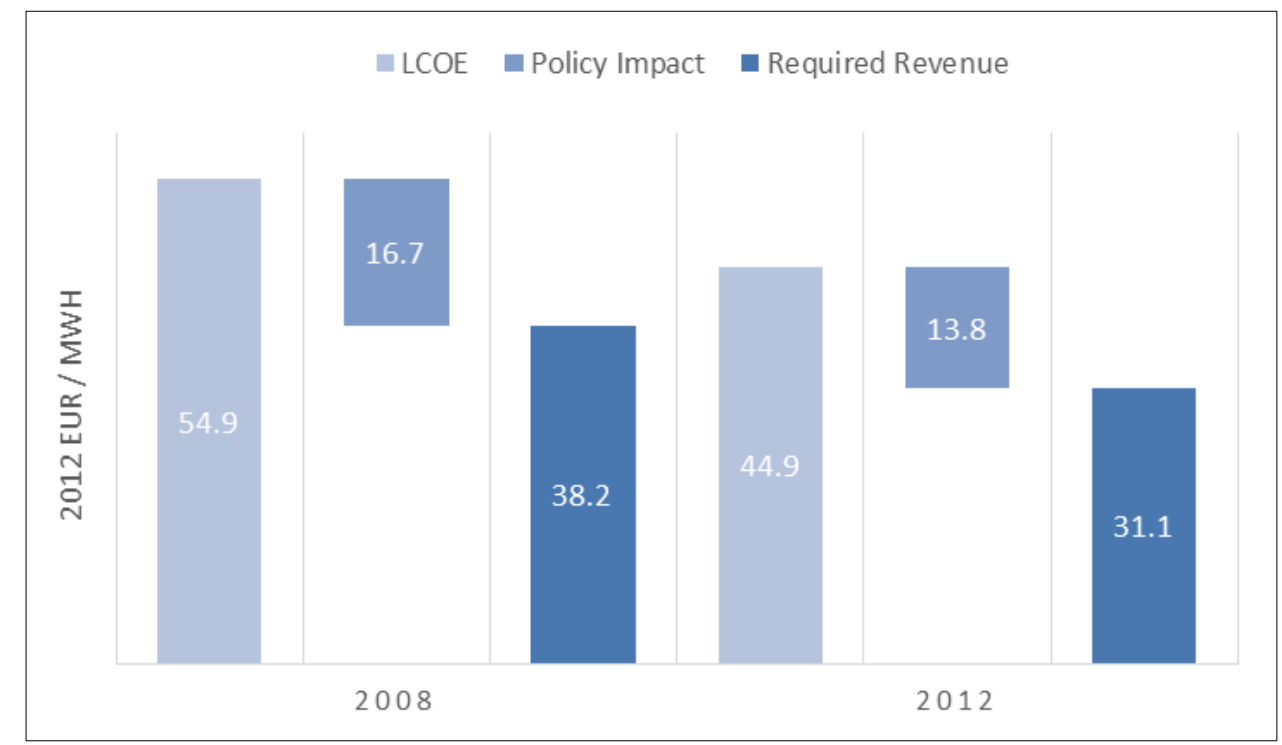

Figure 1-11. LCOE, policy impact, and required revenue in Denmark in 2008 and 2012

The results of the cash flow analysis indicate that the LCOE for wind power in Denmark decreased substantially from 2008 to 2012 . The required revenue also decreased in the same period despite a decrease in the policy impact in real terms.

It should, however, be noted that costs and revenues of wind power projects are always sitespecific and project-specific, and there can be considerable variations across projects. The average values used for the model calculation may not fully capture all of the project-specific variation and are only an estimate.

\section{Power Price Projections and the Financial Gap}

The design of the wind power support policy scheme in Denmark, consisting of FIP in addition to the power market price, makes the market price for power throughout the project's lifetime a critical determinant of the profitability of development and operation of wind power projects.

In this study, financial gap (FG) is the project costs not covered (or exceeded) by revenue streams throughout the lifetime of the wind power project. A positive FG value indicates insufficient revenues to cover all costs; whereas a negative FG value implies that the wind power project developer is yielding returns in excess of market average.

Provided that the LCOE and policy incentives are fixed, Financial Gap is then dependent on the power market price received by the wind power producer. Figure 1-12 illustrates this dependency by showing the FG as a function of average annual power price throughout project lifetime for representative projects as of 2008 and 2012. Values are expressed in 2012 EUR/megawatt-hour (MWh) in real terms. 


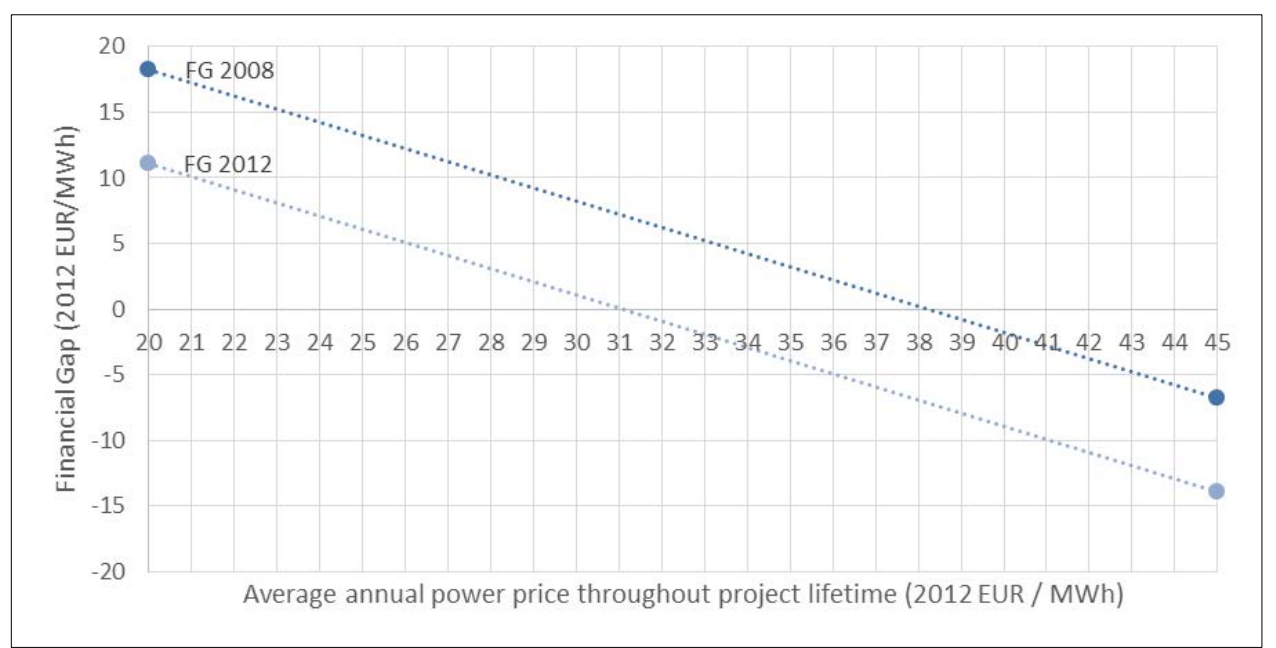

Figure 1-12. FG for the average annual power price in 2008 and 2012

The graph illustrates the sensitivity of the FG towards the realized power market price throughout project's lifetime. A high degree of uncertainty is associated with estimating an exact value for the FG.

First, power prices are volatile and projections thereof are inherently uncertain. Power prices in Denmark can be affected by a number of factors, among them supply and demand dynamics, weather variation (through the level of hydro power production in Norway or wind power production in Denmark and Northern Germany) and policies (renewable energy targets and carbon dioxide prices).

As illustrated by Figure 1-13, there is no consensus as to the development pathway of power prices in Denmark, largely due to the uncertainty associated with the development of critical price determinants in the future. ${ }^{25}$

Second, a distinction should be made between 'average market power prices' and 'average market power prices received by wind power producers' (the difference has been denoted 'price gap' in this analysis). Increased penetration of wind power reduces wholesale spot prices, known as the Merit-Order Effect (Pöyry, 2010). (Due to its low short-run marginal costs, wind power 'pushes out' sources of generation with higher short-run marginal costs.) This effect can have profound implications not only on wholesale power prices, but also on the revenues attained by individual power producers. Depending on, among other factors, the amount of wind power in a particular power market, wind power producers can yield significantly lower average power prices than the average annual market power price due to the production profile exhibited by wind power, which is governed by weather, as opposed to price-maximizing (e.g., it is common for more wind power to be produced during the night, when there is less demand and lower prices, thereby leading to wind power producers receiving a below-average spot price for a large part of the power produced).

\footnotetext{
${ }^{25}$ See the individual studies for more detail on the power price projection assumptions and methodology.
} 


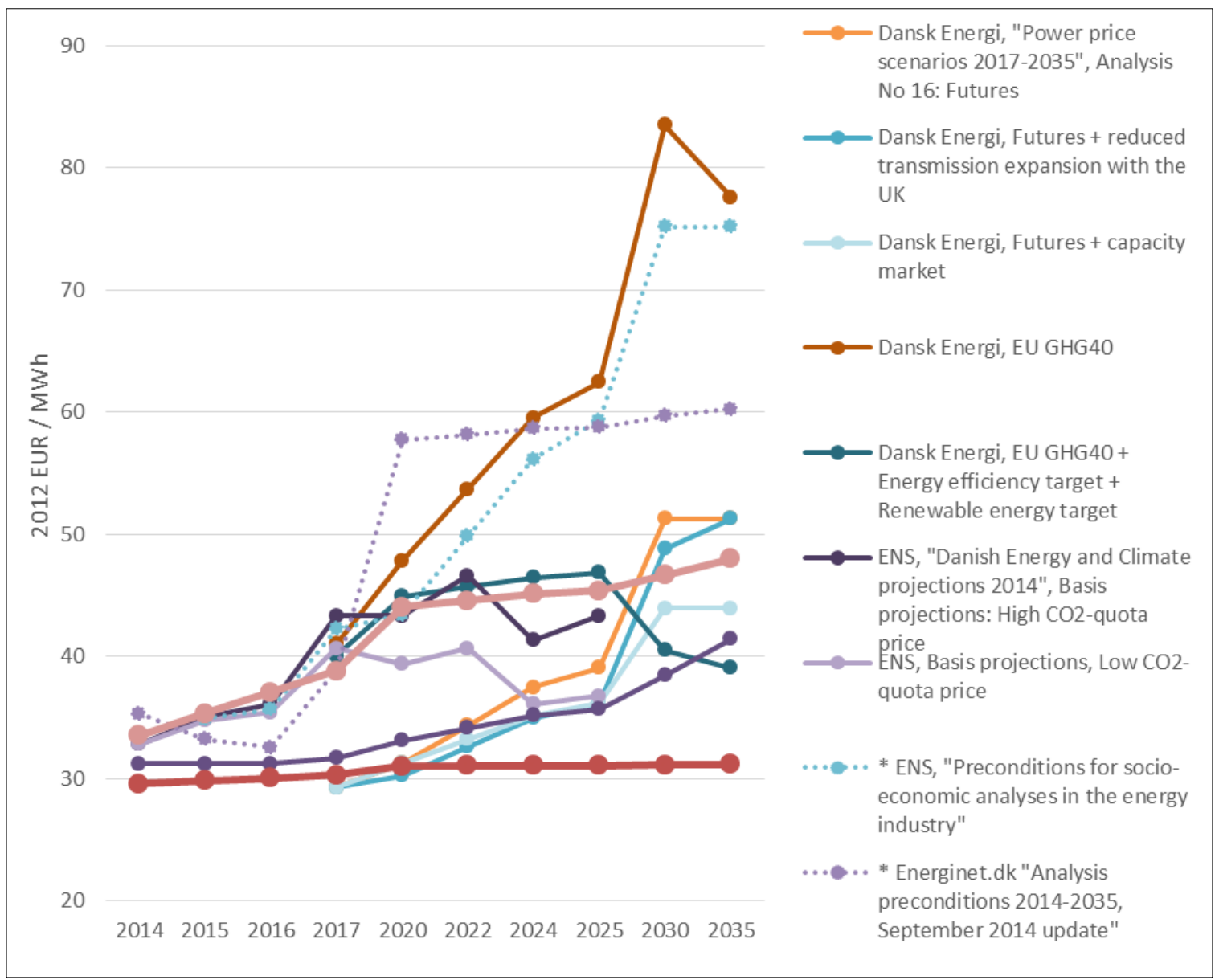

Note: These projections are subject to various preconditions ${ }^{26}$ and use real prices. (Hedegaard, 2014)

* Socio-economic projections (dashed), i.e., not directly comparable to market power prices

Figure 1-13. Power system price projections in Denmark

Analysis of the power market prices in Western Denmark over the period 2002 to 2014 reveals a considerable difference (price gap) in terms of the average annual power price in the market, and the average annual power price received by the wind power producers. The price received by the wind power producers has been consistently lower than the market average, the price gap ranging from $4 \%$ to $15 \%$ relative to the average market price. Based on the results of a system modelling analysis, this price gap is expected to increase considerably in the medium to long term, in line with increasing wind power penetration in Denmark and neighboring countries. The total wind power production in the region (Scandinavia, Germany, and the Netherlands) is projected to nearly double by 2020, and to quadruple by 2035, compared to 2014 levels (Ea Energy Analyses, 2014). The modeled average power market price and wind power producerrealized power price for all Denmark is presented in Figure 1-14 (also presented in Figure 1-13 for full context).

\footnotetext{
${ }^{26}$ Based on the following publications: Danish Energy Agency (Danmarks Energi- og Klimafremskrivning 2014), Danish Energy Agency (Forudsætninger for samfundsøkonomiske analyser på energiområdet), Dansk Energi (Elprisscenarier 2017-2035, Analyse nr. 16), Ea Energy Analyses (Vindintegration i Danmark), Energinet.dk (Energinet.dk's analyseforudsætninger 2014-2035, opdatering september 2014). Linear interpolation has been done if the projection results were not presented annually in the sources.
} 


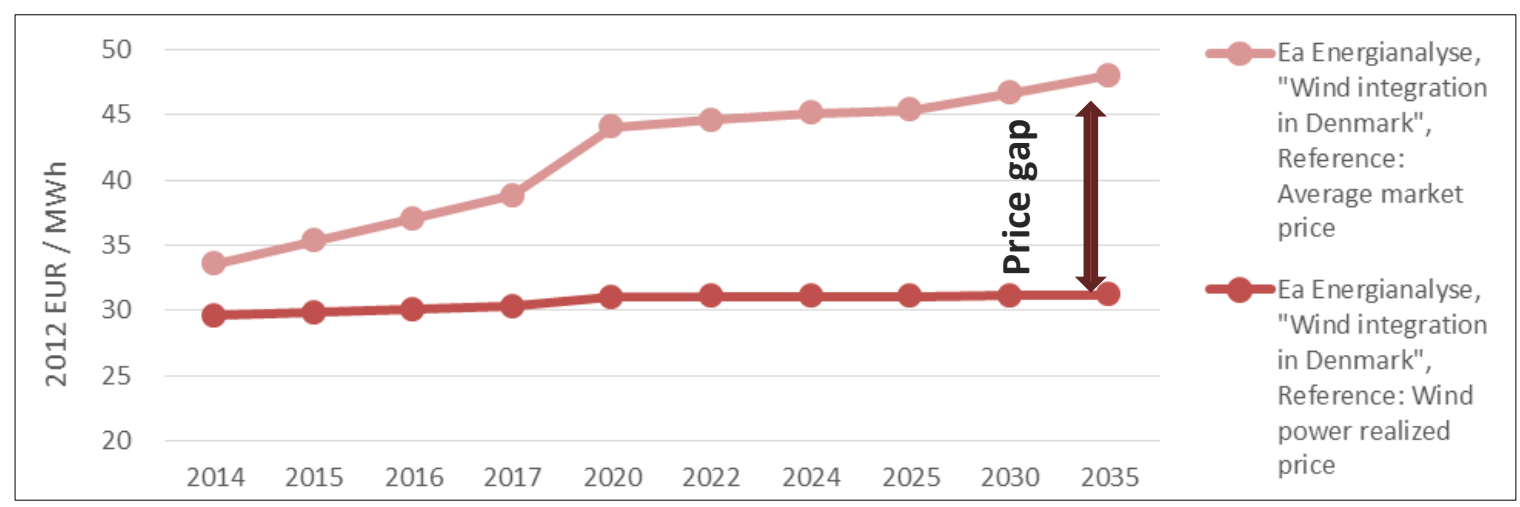

Note: Projections are based on system modeling analysis (Ea Energy Analyses, 2014).

Figure 1-14. Average market price and wind power realized price projections to 2035

The projected wind power realized price is considerably lower than the associated projected average market price (and that it is the lowest in the power price projection sample observed, as illustrated by Figure 1-14.

Table 1-6 presents the wide spectrum of FG estimates obtained based on the different power market price projections. ${ }^{27}$ The FG estimates are negative across all scenarios, generally indicating that the projected revenue streams should be sufficient to cover all wind power project costs (for a typical project installed in 2012) and provide return on investment. It should, however, be noted that some of the projections assume very ambitious national and international political commitments in terms of environment. It should also be noted that cash flow based on the wind power realized price projection yields an FG close to zero (-0.2 EUR/MWh; -0.26 USD/MWh).

Table 1-6. Financial Gap Estimates Based on Various Market Power Price Projections

\begin{tabular}{|lc|}
\multicolumn{1}{|c|}{ Market power price projection } & $\begin{array}{c}\text { Financial Gap } \\
2012 \text { EUR/MWh } \\
(\$ / M W h)\end{array}$ \\
\hline Dansk Energi, EU greenhouse gas (GHG)40 & $-21.3(-\$ 27.4)$ \\
\hline $\begin{array}{l}\text { Dansk Energi, "Power price scenarios 2017-2035", Analysis No } \\
\text { 16: Futures }\end{array}$ & $-5.6(-\$ 7.2)$ \\
\hline $\begin{array}{l}\text { Dansk Energi, Futures + reduced transmission expansion with } \\
\text { the UK }\end{array}$ & $-4.4(-\$ 5.7)$ \\
\hline Dansk Energi, Futures + capacity market & $-3.8(-\$ 4.9)$ \\
\hline $\begin{array}{l}\text { Project budgeting approach (2012 average price for 5 years, } \\
\text { thereafter 1.5\% increase p.a.) }\end{array}$ & $-2.7(-\$ 3.5)$ \\
\hline $\begin{array}{l}\text { Dansk Energi, EU GHG40 + Energy efficiency target + Renewable } \\
\text { energy target }\end{array}$ & $-10.6(-\$ 13.6)$ \\
\hline $\begin{array}{l}\text { Ea Energianalyse, "Wind integration in Denmark", Reference: } \\
\text { Average market price }\end{array}$ & $-10.2(-\$ 13.1)$ \\
\hline $\begin{array}{l}\text { Ea Energianalyse, "Wind integration in Denmark", Reference: } \\
\text { Wind power realized price }\end{array}$ & $\mathbf{- 0 . 2 ( - \$ 0 . 3 )}$ \\
\hline
\end{tabular}

\footnotetext{
${ }^{27}$ Only market power price (i.e., not socio-economic price) projections with a forecast period to 2035 are presented. The actual historic market power prices for 2012 and 2013 are used across all projections.
} 


\section{Summary of Wind Projects in Denmark 2008 to 2012}

The feed-in premium introduced in 2008 renewed interest in land-based wind energy project development in Denmark (following a period of inactivity from 2003 to 2007 caused by a significant reduction in the financial support program). There has been a significant increase in turbine sizes in Danish projects, along with an increase in the capacity factors, in the period 2008-2012. Investment costs were reduced substantially in 2012 compared to the decade-high of 2008; and, based on indications from an industry source; there has also been a decrease in the O\&M costs in real terms. (However, projections of O\&M costs over a wind turbine's lifetime are estimated with great uncertainty.) The average power market price situation, however, has been much more favorable in 2008 relative to 2012.

The prevailing support scheme from 2008 to 2012 was more favorable to operating turbines with larger generators, which is the likely cause for the very high (and increasing) average rated power capacity for newly installed projects in Denmark over the period reviewed. In 2012, the average (and dominant) utility-scale turbine installed in Denmark was $3 \mathrm{MW}$. Rotor sizes and hub heights have also been on the rise in the review period.

Industry sources suggest that more and more wind power projects in Denmark have been developed by professional developers (as opposed to being private initiative/cooperative projects) with the intention of selling them to the utility companies. The average project size and the financing costs have, however, remained largely unchanged in the 2008-2012 period.

The results of the cash flow analysis indicate that the LCOE for wind power in Denmark has decreased substantially from 2008 to 2012. The required revenue has also decreased in the same period despite a decrease in policy impact in real terms, as illustrated by Table 1-7.

Table 1-7. LCOE, Policy Impact, and Required Revenue in Denmark for 2008 and 2012

\begin{tabular}{|l|l|c|c|}
\hline & & $\mathbf{2 0 0 8}$ & $\mathbf{2 0 1 2}$ \\
\hline Levelized cost of energy & $€ / M W h(\$ / M W h)$ & $55(71)$ & $45(58)$ \\
\hline Policy impact & $€ / M W h(\$ / M W h)$ & $17(22)$ & $14(18)$ \\
\hline Required revenue & $€ / M W h(\$ / M W h)$ & $38(49)$ & $31(40)$ \\
\hline
\end{tabular}

The FG is highly dependent on the market prices for power throughout the wind power project's lifetime, and estimation thereof is associated with a high level of uncertainty, in line with the uncertainty of power price projections. The FG estimated for land-based wind power projects installed in 2008 by Schwabe et al. (2011) amounted to -6.7 EUR/MWh or -8.6 USD/MWh (converted to 2012 real currency terms). The FG estimates within the current study for landbased wind power projects installed in 2012 range from -2.7 to $-21.3 \mathrm{EUR} / \mathrm{MWh}(-3.5$ to -27.4 $\mathrm{USD} / \mathrm{MWh}$ ), depending on the market power price projection applied.

A specific manifestation of the Merit-Order Effect (combined with the weather-governed wind power production pattern and amplified by the high penetration of wind power in the generation mix) has been observed in Denmark, namely, a price gap between the average power market price, and the average price received by the wind power producers. Higher wind power penetration in the local and regional power system, among other factors, is projected to increase the price gap in the future. Once this effect is taken into account in the power price projections 
(the corresponding average market power prices being mid-range among the projection sample tested), the FG for wind power projects installed in Denmark in 2012 drops to nearly 0 (-0.2 EUR/MWh; -0.26 USD/MWh).

\section{Perspectives Beyond 2012}

One of the most notable developments in the Danish wind power landscape, following the 20082012 period reviewed in this report, is the land-based wind power support scheme reform. For wind power projects grid-connected as of January $1^{\text {st }}, 2014$, the nominal FIP still amounts to 25 øre $\mathrm{DKK} / \mathrm{kWh}$, yet a nominal price cap has been introduced on the sum of power market price and the FIP, amounting to 58 øre DKK/kWh ( 7.8 cents EUR/kWh and 10.3 cents USD/kWh based on 2014 average exchange rates respectively). This means that when the power market price exceeds 33 øre DKK/kWh (4.4 cents EUR/kWh; 5.9 cents USD/kWh), the FIP is being reduced proportionally. The supplement to cover balancing costs paid throughout a turbine's lifetime (described earlier) remains unchanged (Danish Energy Agency, 2014).

In addition, the power production eligible for FIP is, as of 2014, dependent both on the turbine generator size and the rotor size, and it is calculated using the following formula (replacing the earlier support scheme based on 22,000 full-load hours):

$$
\begin{aligned}
& \begin{array}{l}
\text { Power Production Eligible for FIP } \\
=30 \% \times \text { Turbine rated power }(\mathrm{MW}) \times 22,000 \text { Full load hours } \\
+70 \% \times 8,000 \mathrm{kWh} / \mathrm{m}^{2} \times \text { Rotor swept area }\left(\mathrm{m}^{2}\right)
\end{array} \\
& = \\
& \text { Turbine rated power }(\mathrm{MW}) \times 6,600 \mathrm{Full} \text { load hours }+ \text { Rotor swept area }\left(\mathrm{m}^{2}\right) \times \\
& 5.6 \mathrm{MWh} / \mathrm{m}^{2}
\end{aligned}
$$

For a 3 MW turbine with a 101-m rotor diameter, the power production eligible for FIP would then be:

$$
3 \times 6,600 \text { Full load hours }+\frac{\pi \times 101^{2}}{4} \times 5.6 \frac{M W h}{m^{2}}=64,666 \mathrm{MWh}
$$

The power production eligible for FIP expressed in full load hours (FLH) would then correspond to:

$$
\frac{64,666 M W h}{3 \mathrm{MW}}=21,555 F L H
$$

Provided the average annual production is equivalent to 3,000 full-load hours, this turbine would yield 21,555 full-load hours eligible for FIP (equivalent to 7.2 years of the FIP policy period). A 2-MW turbine with a 90-m rotor, in turn, would yield over 24,000 full-load hours eligible for FIP, equivalent to 8 years of the FIP policy period (based on 3,055 annual production full-load hours). 
In order to illustrate the potential impact of the new support regime, LCOE is calculated using the ECN cash flow model. The projects compared are:

1. A project with 2-MW turbines and a 90-m rotor diameter (based on an actual project in Denmark in 2013, converted to 2012 real prices)

2. The most typical project in Denmark in 2012 (described in detail in the earlier sections of this report)

Table 1-8 provides an overview of the project characteristics, the inputs used in the cash flow model (all other parameters are left unchanged), as well as the resulting policy impact and required revenue of the projects based on either support policy regime. It should be noted, however, that because the market power price input was omitted in the model, the impact of the price cap introduced in the 2014 support policy reform has not been captured.

As the results illustrate, the new support policy regime is relatively more favorable towards the 'smaller generator - larger rotor' 2-MW turbine project rather than the 3-MW turbine project (Required Revenue decreasing for the 2-MW turbine project and increasing for $3 \mathrm{MW}$, respectively). There is also a difference in the FIP policy support period in terms of full load hours of production, the 2-MW turbine project expected to yield relatively more FIP-supported full load hours of production under the new subsidy regime, whilst the opposite is the case for its $3 \mathrm{MW}$ counterpart, respectively. Further analysis would be required to arrive at more general conclusions or projections as to the expected impact of the support scheme reform (and this impact should be regarded taking into account other factors affecting the technological choice of turbines in Denmark, e.g. land availability, regulations, site conditions etc.), yet the analysis presented above provides an illustration of this potential impact on two different individual projects, ceteris paribus.

Other developments (not reflected in the cash flow analysis presented above) include changes in financing terms for wind power projects in Denmark. Whilst the financing terms have remained largely unchanged from 2008 to 2012, there are indications of lower return on equity and return on debt rates in the following years (e.g., for projects planned in 2014), at the nominal level of about $9 \%$ and $4 \%$, respectively (11\% and 5\% nominal for 2008-2012).

In addition, the Danish corporate tax rate will be gradually decreased to reach $22 \%$ by 2016 . It will go down one percentage point per year through 2016 (2013: 25\%, 2014: 24\%, 2015: 23\%, 2016: $22 \%$ ).

The most recent projects (especially in years following 2012) increasingly feature the purchase of the pre-existing turbines and/or real estate as a notable new cost category (excluded in the sample presented here). 
Table 1-8. Comparison of the Impacts of the Different Subsidy Regimes on the Relative Competitiveness of Two Projects

\begin{tabular}{|c|c|c|c|c|c|}
\hline & & \multicolumn{2}{|c|}{ 2-MW Turbine Project } & \multicolumn{2}{|c|}{ 3-MW Turbine Project } \\
\hline $\begin{array}{l}\text { Support } \\
\text { policy regime }\end{array}$ & & 2008-2012 & $\begin{array}{c}2014 \\
\text { onwards }\end{array}$ & 2008-2012 & $\begin{array}{c}2014 \\
\text { onwards }\end{array}$ \\
\hline $\begin{array}{l}\text { Rotor } \\
\text { diameter/hub } \\
\text { height }\end{array}$ & $(\mathrm{m} / \mathrm{m})$ & $90 / 80$ & $90 / 80$ & $101 / 90$ & $101 / 90$ \\
\hline Production & $\begin{array}{l}\text { (full-load } \\
\text { hours) }\end{array}$ & 3,055 & 3,055 & 3,000 & 3,000 \\
\hline $\begin{array}{l}\text { Investment } \\
\text { costs }\end{array}$ & $€ / \mathrm{kW}(\$ / \mathrm{kW})$ & $1,340(\$ 1722)$ & $\begin{array}{c}1,340 \\
(\$ 1,722)\end{array}$ & $1,273(\$ 1,636)$ & $\begin{array}{c}1,273 \\
(\$ 1,636)\end{array}$ \\
\hline $\begin{array}{l}\text { FIP policy } \\
\text { period }\end{array}$ & $\begin{array}{l}\text { (full-load } \\
\text { hours) }\end{array}$ & 22,000 & 24,413 & 22,000 & 21,555 \\
\hline $\begin{array}{l}\text { FIP policy } \\
\text { period }\end{array}$ & (years) & 7.2 & 8.0 & 7.3 & 7.2 \\
\hline $\begin{array}{l}\text { Levelized } \\
\text { cost of } \\
\text { energy }\end{array}$ & $(€ / M W h)$ & $46(\$ 59)$ & $46(\$ 59)$ & $45(\$ 58)$ & $45(\$ 58)$ \\
\hline Policy impact & $(€ / \mathrm{MWh})$ & $14(\$ 18)$ & $15(\$ 19)$ & $14(\$ 18)$ & $12(\$ 15)$ \\
\hline $\begin{array}{l}\text { Required } \\
\text { revenue }\end{array}$ & $(€ / \mathrm{MWh})$ & $32(\$ 42)$ & $31(\$ 40)$ & $31(\$ 40)$ & $33(\$ 43)$ \\
\hline
\end{tabular}

Finally, the accelerated depreciation regime for wind power projects has become less favorable as of 2013. The new rules mandate a maximum of $15 \%$ residual value depreciation per annum on wind turbines instead of the earlier $25 \%$ rate.

\section{References for Chapter 1}

Danish Energy Agency. (2012). Energistyrelsen. Retrieved from Skrotningsordningen - udløb den 15. december 2011: http://www.ens.dk/undergrund-forsyning/vedvarendeenergi/vindkraft-vindmoller/vindmoller-pa-land/skrotningsordningen

Danish Energy Agency. (2013). Energy Statistics 2013. Danish Energy Agency.

Danish Energy Agency. (2013). New Offshore Wind Tenders in Denmark. Copenhagen: Danish Energy Agency. Retrieved from http://www.ens.dk/sites/ens.dk/files/dokumenter/publikationer/downloads/new_offshore wind_tenders_in_denmark_final.pdf

Danish Energy Agency. (2014, March ). Danish Energy Agency. Retrieved from Core Data Registry: http://www.ens.dk/info/tal-kort/statistik-noegletal/oversigtenergisektoren/stamdataregister-vindmoller

Danish Energy Agency. (2014). Danmarks Energi- og Klimafremskrivning 2014. Copenhagen: Energistyrelsen. Retrieved from https://www.google.dk/url?sa $=$ t\&rct=j\&q=\&esrc=s\&source=web\&cd=1\&cad=rja\&uact $=$ $8 \&$ ved $=0 \mathrm{CCIQFjAA \& url=http} \% 3 \mathrm{~A} \% 2 \mathrm{~F} \% 2 \mathrm{Fwww}$. ens.dk $\% 2 \mathrm{Fsites} \% 2 \mathrm{Fens} . \mathrm{dk} \% 2 \mathrm{Ffiles} \%$ 2Fdokumenter\%2Fpublikationer\%2Fdownloads\%2Fdanmarks_energi_og_klimafremskri vning_2014.pdf\&ei=Uji1VJePGMv_Ut7Jg 
Danish Energy Agency. (2014, May 5). Energistyrelsen. Retrieved from Onshore Wind Power: http://www.ens.dk/en/supply/renewable-energy/wind-power/onshore-wind-power

Danish Energy Agency. (2014). Energistyrelsen. Retrieved from Afregning og tilskud til vindmøller: http://www.ens.dk/undergrund-forsyning/el-naturgas-

varmeforsyning/elforsyning/elproduktion/stotte-vedvarende-energi-2

Danish Energy Agency. (2014). Forudscetninger for samfundsøkonomiske analyser på energiområdet. Copenhagen: Energistyrelsen. Retrieved from http://www.ens.dk/sites/ens.dk/files/info/tal-kort/fremskrivninger-analysermodeller/samfundsoekonomiske-beregningsforudsaetninger/2014/braendselsprispublikation_2014___20141209_-_komprimeret.pdf

Danish Energy Agency. (2014). FREMSKRIVNING AF PSO-UDGIFTER. Copenhagen:

Energistyrelsen. Retrieved from http://www.ens.dk/sites/ens.dk/files/energistyrelsen/Nyheder/2014/psofremskrivning_2014_19052014.pdf

Danish Energy Agency. (2015, February 25). Energistyrelsen. Retrieved from Procedures and permits for offshore wind parks: http://www.ens.dk/en/supply/renewable-energy/windpower/offshore-wind-power/procedures-permits-offshore-wind-parks

Danish Ministry of Finance. (2014). Appendix I: Overview of the Individual Inititatives in the Common Understanding between the Government and the Party of the Left. Copenhagen: Ministry of Finance. Retrieved July 2, 2014, from http://www.fm.dk/nyheder/pressemeddelelser/2014/06/mere-end-90-initiativer-skaltraekke-danmark-helt-fri-afkrisen/ /media/Files/Nyheder/Pressemeddelelser/2014/06/Bilag\%201\%20$\% 20$ Oversigt $\% 20$ over $\% 20$ de $\% 20$ enkelte $\% 20$ initiativer $\% 20 \mathrm{i} \% 20 \mathrm{f} \% \mathrm{C} 3 \%$ A6lles $\% 20$ forst $\% \mathrm{C} 3 \% \mathrm{~A} 5$

Danish Wind Turbine Owners' Association. (2012). Status for vindkraftudbygningen i Danmark. Aarhus: Danmarks Vindmølleforening. Retrieved from http://www.dkvind.dk/html/nogletal/pdf/statusnotat_0112.pdf

Danish Wind Turbine Owners' Association. (2014, March). Danmarks Vindmølleforening. Retrieved from Key indices March 2014 (Nøgletal marts 2014): http://dkvind.dk/html/nogletal/pdf/energiindhold/denne_maaned.pdf

Dansk Energi. (2014). Elprisscenarier 2017-2035, Analyse $n r .16$. Dansk Energi. Retrieved from https://www.google.dk/url?sa=t\&rct=j\&q=\&esrc=s\&source=web\&cd=2\&cad=rja\&uact $=$ $8 \&$ ved $=0 \mathrm{CCsQFjAB \& url=http} \% 3 \mathrm{~A} \% 2 \mathrm{~F} \% 2 \mathrm{Fwww}$. ienergi.dk\%2FNyhed $\% 2 \mathrm{~F} 2014 \% 2 \mathrm{~F} \sim$ \%2Fmedia\%2FDE MJE\%2FAnalyser\%2FAnalyse16-Elprisscenarier20172035.ashx\&ei=UDm1VLi9McvraIXZgrgO\&usg=AFQjCNEQa0zQ-O

Ea Energy Analyses. (2014). Installation cost update for 2013 based Local Residents' Purchase Right (Køberetsordning) data.

Ea Energy Analyses. (2014). Vindintegration i Danmark. Danmarks Vindmølleforening. Retrieved from http://www.dkvind.dk/html/nyheder/2014/pdf/041114_rapport.pdf

ECB. (2014, October 6). European Central Bank. Retrieved from Monetary Policy: https://www.ecb.europa.eu/mopo/html/index.en.html

EMD. (2014, March 10). (A. Vitina, Interviewer)

Energinet.dk. (2014, May ). Energinet.dk. Retrieved from Wind Turbine Project Overview database (Vindmølleprojektoversigt): http:/www.energinet.dk/DA/El/Vindmoeller/Defire-VE-ordninger/Sider/Vindmolleprojektoversigt.aspx?utm_source=Nyhedsbrev+- 
+De+Fire+Vindm\%u00f81leordninger\&utm_campaign $=6 \mathrm{~b} 49251 \mathrm{f59}$ -

DFV_Nyhedsbrev_Ny_Vindmoelleprojektoversigt\&utm_medium $=$ email\&utm_term $=0 \_a$ 926

Energinet.dk. (2014). Energinet.dk's analyseforudscetninger 2014-2035, opdatering september 2014. Fredericia: Energinet.dk. Retrieved from http://energinet.dk/SiteCollectionDocuments/Danske\%20dokumenter/El/13-79887-

$18 \% 20$ Energinet $\% 20 \mathrm{dk} \% 27 \mathrm{~s} \% 20$ analyseforuds $\% \mathrm{C} 3 \%$ A6tninger $\% 202014$ 2035\%2c\%20opdatering\%20september\%202014.pdf

Energinet.dk. (2015, February 25). Energinet.dk. Retrieved from Afregning: http://www.energinet.dk/DA/El/Vindmoeller/Afregning/Sider/Afregning.aspx

Finansministeriet. (2013). Vokstplan DK Teknisk baggrundsrapport 2013. Copenhagen: Ministry of Finance of Denmark. Retrieved from http://www.fm.dk/publikationer/2013/vaekstplan-dk-staerke-virksomheder-flerejob/ /media/Publikationer/Imported/2013/V\%C3\%A6kstplan\%20DK/V\%C3\%A6kstplan $\% 20 \mathrm{DK}$ teknisk\%20baggrundsrapport.pdf

Folketinget. (2012). Aftale mellem regeringen (Socialdemokraterne, Det Radikale Venstre, Socialistisk Folkeparti) og Venstre, Dansk Folkeparti, Enhedslisten og Det Konservative Folkeparti om den danske energipolitik 2012-2020. Copenhagen: Energistyrelsen. Retrieved from http://www.ens.dk/sites/ens.dk/files/politik/dansk-klimaenergipolitik/politiske-aftaler-paa-energiomraadet/energiaftalen-22-marts2012/Aftale 22-03-2012_FINAL_ren.doc.pdf

Hedegaard, K. (2014). Ea Energy Analyses internal analysis. Copenhagen: Ea Energy Analyses. Jensen, S. I., \& Olsen, L. M. (2013). Opscetning af nye vindmøller-erstatninger til naboer. En undersøgelse af Taksationsmyndighedens afgørelser. Aarhus: Aarhus Universitet. Retrieved from http://pure.au.dk/portal-asbstudent/files/52882729/Ops_tning_af_nye_vindm_ller_erstatninger_til_naboer.pdf

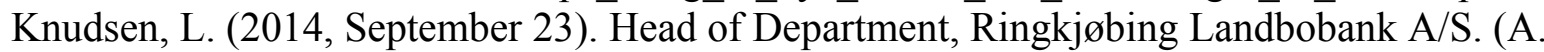
Vitina, Interviewer)

Larsen, J. (2014). Regionale møder "Økonomi og teknik" efterår 2014. Danish Wind Turbine Owners' Association (Danmarks Vindmølleforening). Retrieved from http://www.dkvind.dk/fakta/T2.pdf

Ministry of Climate, Energy and Building. (2013). Energipolitisk redegørelse 2013. Copenhagen: Klima-, energi- og bygningsministeriet.

Nielsen et al. (2010). Economy of Wind Turbines (Original title: Vindmøllers Økonomi). Copenhagen: EUDP .

Nielsen, P. (2013). Danish Wind energy index ver.13 update. Aalborg: EMD International AS. Retrieved from http://www.vindstat.dk/PDF_sider/Windindex_DK_ver\%2013_update.pdf

Pöyry. (2010). Wind Energy and Electricity Prices - Exploring the 'merit order effect'. European Wind Energy Association. Retrieved from http://www.ewea.org/fileadmin/files/library/publications/reports/MeritOrder.pdf Saabye, N. (2003). Risikoprcemie på aktier. Copenhagen: National Bank of Denmark. Schwabe, P., Lensink, S., \& Hand, M. (2011). IEA Wind Task 26: Multi-national Case Study of the Financial Cost of Wind Energy. Golden: National Renewable Energy Laboratory. 
Serrano-González, J., \& Lacal-Arántegui, R. (2015). The regulatory framework for wind energy in EU Member States. Part 1 of the study on the social and economic value of wind energy - WindValueEU. Luxembourg: Publications Office of the European Union.

Skatteministeriet. (2014, September 9). Retsinformation. Retrieved from Bekendtgørelse af lov om skattemæssige afskrivninger (afskrivningsloven):

https://www.retsinformation.dk/Forms/R0710.aspx?id=164300\#P5

\section{Appendix 1-A. Sample Size and Project Data for Denmark}

This appendix contains statistics representing wind project characteristics that are illustrated in the chapter. Table 1-9 describes the sample size of data represented in the subsequent tables. The values in the table correspond to the installed wind project capacity in a given year, or the percentage of annual installed capacity, that is included in the database. For example, an entry of $100 \%$ for Wind Turbine Hub Height means that the statistics shown in the corresponding table and figure for hub height represent $100 \%$ of the turbines installed in that year. 
Table 1-9. Definitions and Sample Size for Denmark

\section{COUNTRY: DENMARK}

\section{DEFINITION OF UTILITY SCALE WIND}

All land-based wind projects equal to or over $1 \mathrm{MW}$ ( $0.5 \mathrm{MW}$ provided where possible)

in size; with all turbines in the project also equal to or over $1 \mathrm{MW}(0.5 \mathrm{MW}$ where

\section{YEAR DATA AGGREGATION}

No data aggregation has been done

\section{OTHER NOTES}

$O$ \& M costs: insufficient data for 'box \& whiskers' chart.

Financing costs: insufficient data for 'box \& whiskers' chart.

\begin{tabular}{|c|c|c|c|c|c|}
\hline \multirow[t]{2}{*}{ SAMPLE (Turbine capacity $1 \mathrm{MW}+$ ) } & \multicolumn{5}{|c|}{ Capacity (Megwatts) } \\
\hline & 2008 & 2009 & 2010 & 2011 & 2012 \\
\hline \multicolumn{6}{|c|}{ Annual Installations -- Land-Based, Utility-Scale Only } \\
\hline Total Wind Power Additions & 61 & 99 & 157 & 188 & 171 \\
\hline \multicolumn{6}{|l|}{ Sample Size -- Land-Based, Utility-Scale Only } \\
\hline Wind Project Size & 61 & 111 & 144 & 190 & 168 \\
\hline Wind Turbine Nameplate Capacity Rating & 61 & 99 & 157 & 188 & 171 \\
\hline Wind Turbine Rotor Diameter & 61 & 99 & 157 & 188 & 171 \\
\hline Wind Turbine Hub Height & 61 & 99 & 157 & 188 & 171 \\
\hline Wind Turbine Specific Power & 61 & 99 & 157 & 188 & 171 \\
\hline Wind Turbine IEC Class & 61 & 79 & 146 & 180 & 136 \\
\hline Annual Average Wind Speed & 61 & 99 & 157 & 188 & 171 \\
\hline Full Load Hours (generation in 2012) & 61 & 99 & 157 & 188 & 171 \\
\hline Investment Costs & na & na & na & na & 127 \\
\hline \multicolumn{6}{|l|}{ Operations and Maintenance Costs } \\
\hline \multicolumn{6}{|l|}{ Financing Costs } \\
\hline \multicolumn{6}{|l|}{ Sample Size (\%) -- Land-Based, Utility-Scale Only } \\
\hline Wind Project Size & $100 \%$ & $112 \%$ & $92 \%$ & $101 \%$ & $98 \%$ \\
\hline Wind Turbine Nameplate Capacity Rating & $100 \%$ & $100 \%$ & $100 \%$ & $100 \%$ & $100 \%$ \\
\hline Wind Turbine Rotor Diameter & $100 \%$ & $100 \%$ & $100 \%$ & $100 \%$ & $100 \%$ \\
\hline Wind Turbine Hub Height & $100 \%$ & $100 \%$ & $100 \%$ & $100 \%$ & $100 \%$ \\
\hline Wind Turbine Specific Power & $100 \%$ & $100 \%$ & $100 \%$ & $100 \%$ & $100 \%$ \\
\hline Wind Turbine IEC Class (known) & $100 \%$ & $80 \%$ & $93 \%$ & $96 \%$ & $80 \%$ \\
\hline Annual Average Wind Speed & $100 \%$ & $100 \%$ & $100 \%$ & $100 \%$ & $100 \%$ \\
\hline Full Load Hours (generation in 2012/2013) & $100 \%$ & $100 \%$ & $100 \%$ & $100 \%$ & $100 \%$ \\
\hline Investment Costs & na & na & na & na & $74 \%$ \\
\hline Operations and Maintenance Costs & $0 \%$ & $0 \%$ & $0 \%$ & $0 \%$ & $0 \%$ \\
\hline Financing Costs & $0 \%$ & $0 \%$ & $0 \%$ & $0 \%$ & $0 \%$ \\
\hline
\end{tabular}


Table 1-10. Wind Project Size Statistics

\begin{tabular}{|l|r|r|r|r|r|r|}
\hline Wind Project Size (MW) & \\
\hline & 2007 & 2008 & 2009 & 2010 & 2011 & 2012 \\
\hline $\mathrm{n}$ (\# projects) & & 28 & 46 & 51 & 69 & 54 \\
\hline median & & 4.6 & 9.1 & 11.2 & 11.8 & 12.0 \\
\hline 25th percentile & & 4.0 & 7.7 & 9.2 & 9.2 & 9.2 \\
\hline 75th percentile & & 8.2 & 11.7 & 15.0 & 15.8 & 14.3 \\
\hline minimum & & 2.0 & 3.0 & 2.0 & 4.0 & 3.6 \\
\hline maximum & & 23.0 & 29.9 & 24.0 & 34.1 & 18.5 \\
\hline average & & 7.6 & 11.1 & 12.0 & 13.6 & 12.0 \\
\hline
\end{tabular}

Salient Notes: All turbines with a known capacity >= $1 \mathrm{MW}$. Source: data provided by the Nature Agency of the Danish Ministry of the Environment

Table 1-11. Wind Turbine Nameplate Capacity Rating Statistics

\begin{tabular}{|l|r|r|r|r|r|r|} 
Wind Turbine Nameplate Capacity Rating (MW) \\
\hline & 2007 & 2008 & 2009 & 2010 & 2011 & 2012 \\
\hline $\mathrm{n}$ (\# turbines) & & 28 & 40 & 55 & 71 & 55 \\
\hline median & & 2.3 & 2.3 & 3 & 3 & 3 \\
\hline 25th percentile & & 2 & 2.3 & 2.3 & 2.2 & 3 \\
\hline 75th percentile & & 2.3 & 2.5 & 3 & 3.1 & 3.1 \\
\hline minimum & & 2 & 1.8 & 2 & 2 & 3 \\
\hline maximum & & 2.3 & 3.6 & 3.6 & 3.6 & 6 \\
\hline average & & 2.2 & 2.5 & 2.9 & 2.6 & 3.1 \\
\hline
\end{tabular}

Salient Notes: All turbines with a known capacity >= $1 \mathrm{MW}$

Table 1-12. Wind Turbine Rotor Diameter Statistics

\begin{tabular}{|c|c|c|c|c|c|c|}
\hline \multicolumn{7}{|c|}{ Wind Turbine Rotor Diameter (m) } \\
\hline & 2007 & 2008 & 2009 & 2010 & 2011 & 2012 \\
\hline n (\# turbines) & & 28 & 40 & 55 & 71 & 55 \\
\hline median & & 92 & 93 & 92 & 93 & 101 \\
\hline 25th percentile & & 80 & 90 & 90 & 85 & 101 \\
\hline 75th percentile & & 92 & 93 & 93 & 112 & 112 \\
\hline minimum & & 80 & 80 & 80 & 80 & 90 \\
\hline maximum & & 93 & 107 & 120 & 120 & 154 \\
\hline average & & 87.5 & 93.1 & 95.6 & 96.9 & 105.0 \\
\hline
\end{tabular}

Salient Notes: All turbines with a known capacity $>=1 \mathrm{MW}$ 
Table 1-13. Wind Turbine Hub Height Statistics

\begin{tabular}{|l|r|r|r|r|r|r|} 
Wind Turbine Hub Height (m) & & & \\
\hline & 2007 & 2008 & 2009 & 2010 & 2011 & 2012 \\
\hline $\mathrm{n}$ (\# turbines) & & 28 & 40 & 55 & 71 & 55 \\
\hline median & & 80 & 80 & 80 & 80 & 89.5 \\
\hline 25th percentile & & 75.25 & 80 & 80 & 73.5 & 80 \\
\hline 75 th percentile & & 80 & 80 & 80 & 88 & 94 \\
\hline minimum & & 60 & 60 & 59.9 & 60 & 79.5 \\
\hline maximum & & 80 & 98.5 & 94 & 100 & 120 \\
\hline average & & 76.2 & 80.0 & 81.7 & 79.2 & 87.5 \\
\hline
\end{tabular}

Salient Notes: All turbines with a known capacity >= $1 \mathrm{MW}$

Table 1-14. Wind Turbine Specific Power Statistics

\begin{tabular}{|l|r|r|r|r|r|r|} 
Wind Turbine Specific Power $\left(\mathbf{W} / \mathbf{m}^{2}\right)$ \\
\hline $\mathrm{n}$ (\# turbines) & 2007 & 2008 & 2009 & 2010 & 2011 & 2012 \\
\hline Median & & 28 & 40 & 55 & 71 & 55 \\
\hline 25th percentile & & 346 & 339 & 398 & 339 & 374 \\
\hline 75th percentile & & 346 & 339 & 342 & 312 & 312 \\
\hline Minimum & & 398 & 380 & 472 & 398 & 374 \\
\hline Maximum & & 339 & 283 & 312 & 229 & 280 \\
\hline Average & & 398 & 472 & 472 & 472 & 472 \\
\hline
\end{tabular}

Salient Notes: All turbines with a known capacity >= $1 \mathrm{MW}$

Table 1-15. Wind Turbine IEC Class Statistics

Wind Turbine IEC Class - Average Class (proportion of installed
capacity)
\begin{tabular}{|l|r|r|r|r|r|r|}
\hline & 2007 & 2008 & 2009 & 2010 & 2011 & 2012 \\
\hline Class I & & $100 \%$ & $73 \%$ & $84 \%$ & $56 \%$ & $46 \%$ \\
\hline Class II & & $0 \%$ & $7 \%$ & $9 \%$ & $40 \%$ & $34 \%$ \\
\hline Unknown & & $0 \%$ & $20 \%$ & $7 \%$ & $4 \%$ & $20 \%$ \\
\hline Average (known IEC class) & & 1.0 & 1.1 & 1.1 & 1.4 & 1.4 \\
\hline n (\# turbines) & & 28 & 40 & 55 & 71 & 55 \\
\hline n (\# turbines, known IEC class) & & 28 & 34 & 52 & 67 & 45 \\
\hline
\end{tabular}

Salient Notes: All turbines with capacity $>=1 \mathrm{MW}$, for all projects $>=1 \mathrm{MW}$. "Average" class is defined for the purpose of showing trends in the average IEC Class 
Table 1-16. Average Annual Wind Speed Statistics

Average Annual Wind Speed @
\begin{tabular}{|l|r|r|r|r|r|r|}
\hline $100 \mathrm{~m}$ \\
\hline & 2007 & 2008 & 2009 & 2010 & 2011 & 2012 \\
\hline $\mathrm{n}$ (\# turbines) & & 28 & 40 & 55 & 71 & 55 \\
\hline median & & 7.77 & 8.18 & 7.84 & 7.53 & 7.29 \\
\hline 25th percentile & & 7.60 & 7.27 & 7.40 & 7.29 & 7.20 \\
\hline 75th percentile & & 8.07 & 8.23 & 8.32 & 8.34 & 7.91 \\
\hline minimum & & 7.05 & 6.88 & 6.57 & 7.00 & 6.90 \\
\hline maximum & & 9.50 & 9.24 & 8.81 & 9.58 & 10.19 \\
\hline average & & 8.04 & 7.94 & 7.92 & 7.89 & 7.57 \\
\hline
\end{tabular}

Salient Notes:

All turbines with a known capacity of $1 \mathrm{MW}+$.

Wind speed areas divided into ca. $1 \mathrm{sq}-\mathrm{km}$ segments (based on data provided by the Danish Nature Agency, created by the EMD).

Wind speed segments matched to the coordinates of each individual wind turbine based on data from the Stamdataregister

Wind speed data was available for $70 \mathrm{~m}$ and $100 \mathrm{~m}$ heights for each segment.

Table 1-17. Capacity Factor and Full Load Hour Statistics in 2013

\begin{tabular}{|c|c|c|c|c|c|c|}
\hline Full Load Hours in 2013, normal wi & ear $(e$ & ent to & city fac & $* 8784$ & & \\
\hline Project COD & 2007 & 2008 & 2009 & 2010 & 2011 & 2012 \\
\hline median & - & 3,004 & 3,121 & 3,125 & 3,222 & 3,061 \\
\hline 25th percentile & - & 2,869 & 2,845 & 2,628 & 2,286 & 2,613 \\
\hline 75th percentile & - & 3,170 & 3,569 & 3,444 & 3,714 & 3,336 \\
\hline minimum & - & 2,656 & 2,349 & 1,590 & 2,017 & 1,873 \\
\hline maximum & - & 3,627 & 4,139 & 4,056 & 5,044 & 3,866 \\
\hline generation-weighted average & - & 3,068 & 3,228 & 3,173 & 3,339 & 3,043 \\
\hline
\end{tabular}

Capacity Factor in 2013, normal wind year (equivalent to full load hours divided by 8784)

\begin{tabular}{|l|r|r|r|r|r|r|}
\hline & 2007 & 2008 & 2009 & 2010 & 2011 & 2012 \\
\hline median & $0.0 \%$ & $34.2 \%$ & $35.5 \%$ & $35.6 \%$ & $36.7 \%$ & $34.9 \%$ \\
\hline 25th percentile & $0.0 \%$ & $32.7 \%$ & $32.4 \%$ & $29.9 \%$ & $26.0 \%$ & $29.7 \%$ \\
\hline 75th percentile & $0.0 \%$ & $36.1 \%$ & $40.6 \%$ & $39.2 \%$ & $42.3 \%$ & $38.0 \%$ \\
\hline minimum & $0.0 \%$ & $30.2 \%$ & $26.7 \%$ & $18.1 \%$ & $23.0 \%$ & $21.3 \%$ \\
\hline maximum & $0.0 \%$ & $41.3 \%$ & $47.1 \%$ & $46.2 \%$ & $57.4 \%$ & $44.0 \%$ \\
\hline generation-weighted average & $0.0 \%$ & $34.9 \%$ & $36.7 \%$ & $36.1 \%$ & $38.0 \%$ & $34.6 \%$ \\
\hline
\end{tabular}


Table 1-18. Investment Costs Statistics

\begin{tabular}{|c|c|c|c|c|c|c|}
\hline \multicolumn{7}{|c|}{ Wind Project Investment Costs (2012 EUR per kW) } \\
\hline & 2007 & 2008 & 2009 & 2010 & 2011 & 2012 \\
\hline median & & 1448.40 & 1371.06 & 1467.38 & 1307.97 & 1278.64 \\
\hline 25th percentile & & 1385.99 & 1252.00 & 1317.39 & 1135.04 & 1074.79 \\
\hline 75th percentile & & 1571.51 & 1655.12 & 1529.85 & 1403.47 & 1402.97 \\
\hline minimum & & 1158.71 & 1151.31 & 969.42 & 1068.01 & 919.938 \\
\hline maximum & & 1913.69 & 1819.26 & 1628.26 & 1474.25 & 1505.11 \\
\hline capacity-weighted average & & 1474.99 & & & & 1273.05 \\
\hline
\end{tabular}

\begin{tabular}{|c|c|c|c|c|c|c|}
\hline ind Project Investment & $(2012)$ & SD per $k$ & & & & \\
\hline & 2007 & 2008 & 2009 & 2010 & 2011 & 2012 \\
\hline median & & 1860.99 & 1761.62 & 1885.39 & 1680.56 & 1642.88 \\
\hline 25th percentile & & 1780.80 & 1608.64 & 1692.67 & 1458.38 & 1380.96 \\
\hline 75th percentile & & 2019.17 & 2126.60 & 1965.65 & 1803.27 & 1802.63 \\
\hline minimum & & 1488.79 & 1479.28 & 1245.57 & 1372.24 & 1182.00 \\
\hline maximum & & 2458.83 & 2337.50 & 2092.09 & 1894.21 & 1933.87 \\
\hline capacity-weighted average & & 1895.16 & & & & 1635.70 \\
\hline
\end{tabular}




\section{Chapter 2. Wind Energy Development in Germany}

Authors: Silke Lüers (Deutsche WindGuard), Anna-Kathrin Wallasch (Deutsche WindGuard), Volker Berkhout (Fraunhofer IWES)

This chapter should be cited as: Lüers, S.; Wallasch, A.; and V. Berkhout (2015). "Wind Energy Development in Germany," Chapter 2. Hand, M. M., ed., IEA Wind Task 26 - Wind Technology, Cost, and Performance Trends in Denmark, Germany, Ireland, Norway, the European Union, and the United States: 2007-2012. NREL/TP-6A20-64332. Golden, CO: National Renewable Energy Laboratory. pp. 48-74.

\section{Domestic Wind Energy Capacity, Production, and Targets}

The following describes the German wind energy development and targets. Figure 2-1 indicates land-based and offshore cumulative and annual capacity installations, projections of near-term and long-term targets by year. ${ }^{28}$

Wind energy development in Germany commenced in the early 1990's when the "Stromeinspeisungsgesetz" (Act on the Sale of Electricity to the Grid) was established and started to support the generation and feed-in of renewable energy, and was continued by the EEG - Erneuerbare Energien Gesetz (Renewable Energy Law). Since then, 35 GW of land-based wind energy capacity has been installed across Germany. Annual installed capacity remained in a range from $1.4 \mathrm{GW}$ to $4.8 \mathrm{GW}$ over a 15 -year period from 1999. After a steep increase to up to $3.2 \mathrm{GW}$ of land-based capacity installations after inception of the German renewable energy law (details below), annual installations decreased to $1.4 \mathrm{GW}$ from 2002 to 2010. Installation numbers started growing again in 2010. In 2014, a capacity of $4.8 \mathrm{GW}$ was added. For the coming years, the government defined a net capacity addition target (capacity additions minus decommissioned capacity) of $2.5 \mathrm{GW}$ annually. Up to the end of 2016, the installations presumably will be higher due to anticipatory effects caused by the expected tendering system (starting in 2017).

The first German offshore wind plant, the test site alpha ventus, started operation in 2010. By the end of 2014, eight projects were connected to the grid and started feeding-in. Several more are under construction. By the end of 2014, 1.0 GW of offshore wind energy capacity was installed and operating. The total offshore wind energy capacity is expected to increase to about $3 \mathrm{GW}$ by 2015, taking the wind plants under construction in 2014 into account. The offshore wind energy development target of the German Federal Government was lowered in 2014 from $10 \mathrm{GW}$ to $6.5 \mathrm{GW}$ by 2020 and from $25 \mathrm{GW}$ to $15 \mathrm{GW}$ by 2030 .

Wind energy yield increased from 40.6 terawatt-hours (TWh) in 2008 to 50.7 TWh in 2012. In 2012 wind energy provided for $8.4 \%$ of electricity produced in Germany. The share of renewable energy in electricity production was approximately $23.6 \%$ in 2012.

\footnotetext{
${ }^{28}$ Projections are derived from governmental targets. Long-term projection targets in particular might change with time.
} 


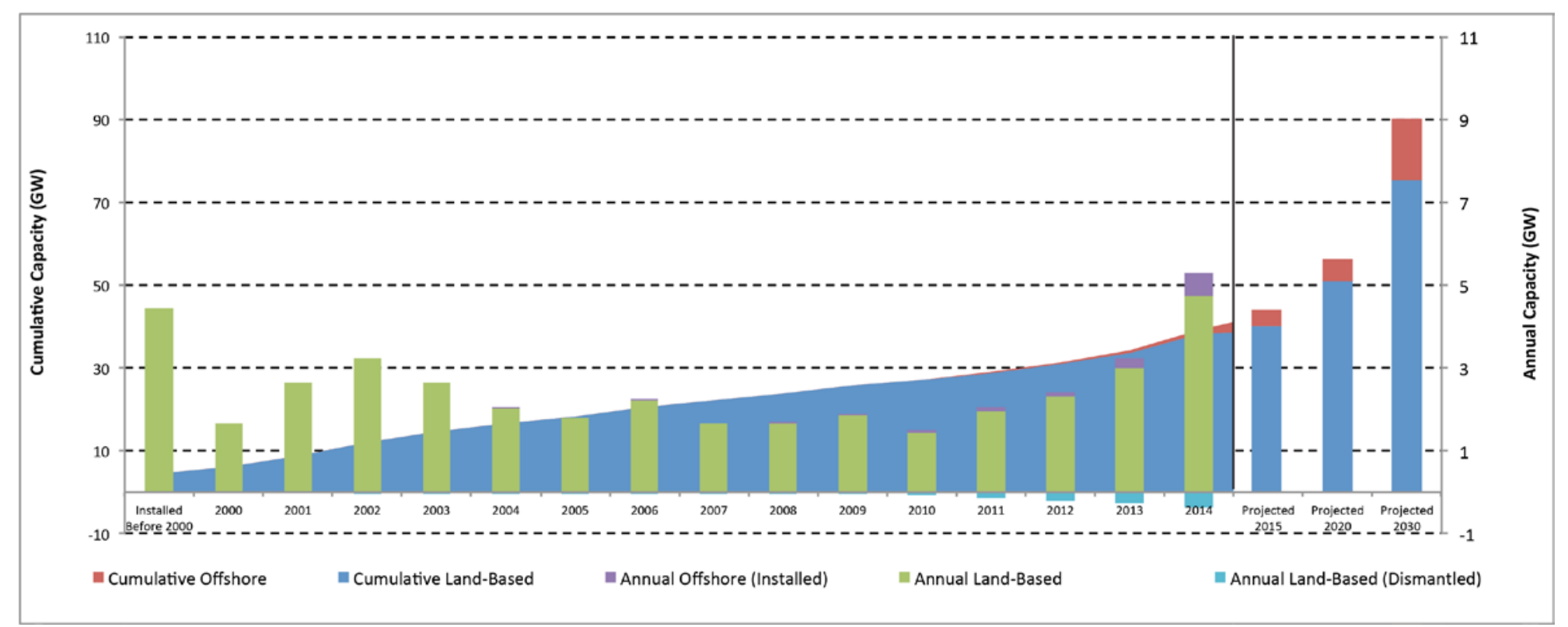

Figure 2-1. Cumulative and annual wind installations in Germany

Table 2-1. Cumulative and Annual Capacity (GW) Installed in Germany

Wind Project Capacity and Targets (GW)

PROJECTIONS

\begin{tabular}{|c|c|c|c|c|c|c|c|c|c|c|c|c|c|c|c|c|c|c|c|c|}
\hline & & $<2000$ & 2000 & 2001 & 2002 & 2003 & 2004 & 2005 & 2006 & 2007 & 2008 & 2009 & 2010 & 2011 & 2012 & 2013 & 2014 & 2015 & 2020 & 2030 \\
\hline Cumulative & Land-Based & 4.4 & 6.1 & \begin{tabular}{|l|}
8.8 \\
\end{tabular} & 12.0 & 14.6 & 16.6 & 18.4 & 20.6 & 22.2 & 23.8 & 25.6 & 27.0 & \begin{tabular}{|l|}
28.9 \\
\end{tabular} & \begin{tabular}{|c|}
31.0 \\
\end{tabular} & 33.7 & 38.1 & 38.7 & 51.2 & \\
\hline Cumulative & Offshore & 0.0 & 0.0 & 0.0 & 0.0 & 0.0 & 0.0 & 0.0 & 0.0 & 0.0 & 0.0 & 0.0 & 0.1 & 0.2 & 0.3 & 0.5 & 1.0 & 2.4 & 6.5 & 80 \\
\hline Annual & Land-Based (Inst & 4.4 & 1.7 & 2.7 & 3.2 & 2.6 & 2.0 & 1.8 & 2.2 & 1.7 & 1.7 & 1.9 & 1.4 & 1.9 & 2.3 & 3.0 & 4.8 & 2.5 & 2.5 & \\
\hline Annual & Offshore (Installed) & 0.0 & 0.0 & 0.0 & 0.0 & 0.0 & 0.0 & 0.0 & 0.0 & 0.0 & 0.0 & 0.0 & 0.1 & 0.1 & 0.1 & 0.2 & 0.5 & & & \\
\hline
\end{tabular}




\section{Revenue and Policy Incentives}

The first regulations for wind energy feed-in tariffs (FITs) ${ }^{29}$ in Germany were enacted in the "Stromeinspeisungsgesetz" (Act on the Sale of Electricity to the Grid) in 1991. In 2000, the law was replaced by the "Erneuerbare Energien Gesetz (EEG)" (Renewable Energy Act). Since then, the EEG has been the primary support scheme for renewable energy in Germany. The latest amendment (EEG 2014) came into effect on August 1, 2014. The general outline of the law is described below. Important aspects of the current and preceding versions relevant to the observed period (2007-2012) are also described (EEG 2004, EEG 2009, and EEG 2012).

The EEG regulates the support of all types of renewable energy, including land-based and offshore wind. Onshore wind terms are described in the following.

The EEG defines two different FITs, a basic tariff and a higher initial tariff. Each wind energy project supported by the EEG receives the higher initial tariff for at least 5 years. The duration of the claim for the initial tariff can be extended up to 20 years, depending on the quality of the wind site. This claim duration is calculated for each installed wind turbine after five years of operation dependent on its received energy yield in that time based on the "reference yield model".

For every wind turbine type, a specific reference yield is defined. The reference yield is the energy production of a turbine type on a reference site with an average annual wind speed of 5.5 $\mathrm{m} / \mathrm{s}$ at a height of $30 \mathrm{~m}$ above ground, a logarithmic wind profile, a roughness length of $0.1 \mathrm{~m}$, and a Rayleigh distribution. The quality of the reference site is defined to be $100 \%$.

The energy yield of an actual wind turbine is compared to the reference yield of that turbine type and hence the quality of the actual wind site can be calculated (as a percentage of the reference site quality). Turbines with a very high site quality receive no more than five years of the initial tariff and 15 years of the basic tariff. Turbines with lower site quality get an extension of the claim duration for the initial tariff up to 20 years. Most of the turbines installed in Germany, especially those in the inland are eligible for close to 20 years of the high initial tariff because very good wind sites are rare. This system was set up to enable wind energy installation not only in the coastal areas but all over Germany.

\section{EEG 2004}

The EEG 2004 replaced the original version of the law (EEG 2000) on August 1, 2004. The general baseline of the law did not change. The basic tariff in the EEG 2004 was lowered to $€ 55 / \mathrm{MWh}$ and the initial tariff was set at $€ 87 / \mathrm{MWh}$. Both tariffs decreased at an annual rate of $2 \%$. This means, a turbine installed in 2005 receives a $2 \%$ higher tariff than a turbine installed in 2006. For repowering projects, the duration of the initial tariff was prolonged by an additional extension factor (depending on the site quality) as an incentive to replace old turbines.

\footnotetext{
${ }^{29}$ The FITs in this chapter are not displayed in $2012 €$ because the values are fixed in the law.
} 


\section{EEG 2009}

The EEG 2009 replaced the EEG 2004 on January 1, 2009. The basic tariff in the EEG 2009 was $€ 50.2 / \mathrm{MWh}$ and the initial tariff was set at $€ 92 / \mathrm{MWh}$. Both tariffs decreased at an annual rate of $1 \%$. In addition to the feed-in tariff, a wind energy project can receive different bonuses if it fulfills specific requirements. The EEG 2004 repowering incentive was replaced by a repowering bonus system. The repowering bonus, amounting to $€ 5 / \mathrm{MWh}$ in 2009 , was paid if the new turbine was replacing an old turbine at the turbine location or nearby (neighboring commune or administrative district). The ancillary services bonus ( $€ 5 / \mathrm{MWh}$ in 2009$)$ was paid if the turbines had the capability to deliver system services like low-voltage ride-though capabilities to the grid. For turbines installed in July 2010 or later, the fulfilment of the ancillary service requirements is mandatory, but they still receive a bonus. Both bonuses are paid for the initial FIT duration ( 5 to 20 years).

\section{EEG 2012}

The EEG 2012 came into effect January 1, 2012. The basic tariff in the EEG 2012 was $€ 48.7 / \mathrm{MWh}$, and the initial tariff was set at $€ 89.3 / \mathrm{MWh}$ in 2012 . The tariffs decreased annually at a rate of $1.5 \%$. The repowering and ancillary services bonuses persisted and were set at $€ 5 / \mathrm{MWh}$ for repowering and $€ 4.8 / \mathrm{MWh}$ in 2012 for ancillary services, paid as long as the initial FIT.

One important change which came in place with the EEG 2012 is the introduction of the market premium scheme: Wind turbine operators can voluntarily participate in that scheme and use direct marketing instead of selling the energy to the TSO. When using direct marketing, the operator does not get the usual feed-in tariff anymore but gets paid the difference between the feed-in tariff (plus bonuses applying for the specific turbine) and the average energy market price as a feed-in premium. Furthermore, an incentive is set via an additional bonus the plant operator gets in that system: the management bonus, which should balance the additional marketing costs and which amounts to $€ 12 / \mathrm{MWh}$ in 2012 and was reduced to $€ 6.5-7.5 / \mathrm{MWh}$ in 2013.

\section{EEG 2014}

The EEG 2014, which came into effect on August 1, 2014, included several major changes. Direct marketing became mandatory, bonus payments were abolished and a systematic change to a tendering model as required by the Guidelines on State aid for environmental protection and energy 2014-2020 from the European Commission (EC 2014), which will be introduced by 2017.

The shift to direct marketing means that plant operators do not receive a fixed FIT anymore. Instead they receive the difference between the average wind energy market price and the FIT as a feed-in premium (FIP) on top of the price they received for their energy on the wholesale market. (The difference is calculated individually for each turbine.)

The new basic tariff in the EEG 2014 is $€ 49.5 / \mathrm{MWh}$ and the initial tariff was set at $€ 89 / \mathrm{MWh}$ in 2014. The degression rate is flexible and depends on the annual additional net wind energy capacity. If more capacity than the annual target of 2,500 MW ( $\pm 100 \mathrm{MW})$ was added during a year before the regression date (January 1, April 1, July 1, and October 1 for every year starting 
on January 1, 2016), the regression will increase. In the case of very low capacity additions (less than 1,800 MW), the regression rate turns negative and, therefore, leads to increasing tariffs. This results in a span of the degression rate for every quarter of $-0.4 \%$ to $1.2 \%$.

The repowering bonus and ancillary services bonus were canceled in the EEG 2014. The next amendment of the Renewable Energy Act is expected by the end of 2016, because, according to the EEG 2014, a tendering model for wind energy (among other renewable energies) is going to be implemented by 2017 .

\section{KfW Loans}

Another indirect incentive for the development of wind energy in Germany are "Kreditanstalt für Wiederaufbau" (KfW) loans. In Germany the KfW offers loans with special conditions for defined purposes, among others the financing of renewable energy projects. Most of the German land-based wind energy projects are financed through project financing and use the KfW loans as a part of the financing.

\section{Wind Energy Project Trends in Germany since 2007}

This section describes the typical German wind energy projects features, project performances and project costs. Although the focus is on development from 2007 to 2012, data for 2013 and 2014 are included in the analysis if available in order to provide an up-to-date perspective.

Wind energy turbines installed in Germany have substantially increased in size since 2007. This growth affects rotor diameters, as well as hub heights and capacity ratings. The main turbine size for new installations has increased from 2-MW to 3-MW class.

As many wind sites in low-wind areas of Germany are being developed, new turbine models with lower specific power for weak wind conditions are being developed and introduced into the market. The turbines are characterized by large rotor diameters and hub heights and a comparatively small generator. Therefore, the model range available to wind developers has been diversified with specific turbine characteristics for the individual site, ranging from turbines for strong wind sites to low wind speed turbines.

The data used for the analysis are mainly taken from the German operator's database (Betreiber Datenbasis [BDB]) and Deutsche WindGuard statistical data (DWG 2012ff). The BDB provides turbine and installation master data on wind energy projects in Germany, and it also gives the production data of turbines for a much smaller sample size. Deutsche WindGuard statistical wind energy development data have been collected since 2012 and provides turbine installation and configuration data. Fraunhofer IWES adds turbine master data; e.g., for the International ElectroTechnical Commission (IEC) IEC class analysis of installations. The IEC classification for a wind turbine is governed, in part, by the annual average wind speed for the turbine design. These data are used to represent turbine configurations for 2012 and the years following.

Deutsche WindGuard implemented data surveys on the actual wind energy project costs of German manufacturers, project developers, and operators (DWG 2009, DWG 2009, DWG 2013). These data are used for the CAPEX and OPEX analysis. 
Data are limited to projects on a commercial scale. For installations in Germany, this means that all data analysis includes turbines starting from 500-kW nameplate capacity.

\section{Project Features}

Wind energy projects can be described by many different parameters. The project size, turbine capacity, rotor diameter, hub height, specific power, and IEC class of installed turbines in German wind energy projects are outlined in the following subsections. If available, average, minimum, $25^{\text {th }}$ percentile, median, $75^{\text {th }}$ percentile and maximum project feature values of landbased turbines installed from 2007 to 2014 are depicted in charts.

Because Germany is a rather densely populated country, the project size for wind plants is comparatively low. Detailed figures are difficult to find in literature or through industry sources. Wind energy projects include newly built plants as well as existing plants where one or two turbines are being added or replaced. The available data are not sufficient to allow for a quantitative, reliable analysis.

The size of wind plants in Germany mainly depends on the available area for wind plant development, which is provided and defined by the federal state's regional and land use planning. The main factor limiting the available area is the distance to residential areas. As there is also the need for good wind conditions at a site, it is even harder to locate large, good wind sites in the more complex terrain in central and southern Germany.

An analysis conducted by Deutsche WindGuard proves that the average wind plant in Germany consists of three turbines. About 14\% of turbines erected in 2013 and the first half of 2014 have been installed as single turbine projects (which include the addition to existing plants of older turbines or larger projects split into subsidiaries because of multiple project stakeholders). Fortyfive percent of installed turbines are part of two to five turbine projects, and $25 \%$ are part of $6-$ 10 turbine projects. Only $16 \%$ of turbines have been installed within plants consisting of more than 10 turbines. $^{30}$

There is an increasing trend in the nameplate capacity between 2007 and 2014, as depicted in Figure 2-2. A box and whiskers format is used to represent the projects or turbines that achieved commercial operation in a given year including the median (horizontal line), average (diamond), 25 th to 75 th percentile (box), and minimum and maximum (whiskers). While during 2007 to 2009 , turbines of the 2.0-MW class dominated the German market (market share of more than $50 \%$ ), the importance of 2.3-MW turbines grew from 2010 to 2012. The average nameplate capacity of a turbine installed in 2012 was $2.4 \mathrm{MW}$. After 2012 the installation of 3-MW turbines became more common, leaving the old standard 2.0-MW turbines behind.

The average turbine capacity rose by $26 \%$ from 1.9 to $2.4 \mathrm{MW}$ between 2007 and 2012 . While in 2014 , the average turbine size was at 2.7 MW. This development is driven by the technical innovations and the entrance of larger turbines into the market. In Germany, where available sites for wind energy development are limited, larger turbines contribute to an efficient deployment of wind energy generation capabilities. Considering planning periods, German wind

\footnotetext{
${ }^{30}$ Analysis of 2013 and first half of 2014 statistical data is from Deutsche WindGuard.
} 
plant developers and operators shifted to the utilization of new turbine classes relatively quickly after new turbine models became available.

The smallest utility-scale turbines installed on land in Germany remained at $600 \mathrm{~kW}$, while the largest turbine installed in Germany was rated at $6 \mathrm{MW}$ and then uprated to $7.5 \mathrm{MW}$ in 2010 with an rotor diameter of $126 \mathrm{~m}$. Turbines of $2 \mathrm{MW}$ or less had a share of only $8 \%$ of the installed turbines in 2014. The biggest share of turbines installed in 2014 (59\%) have a nameplate capacity above $2 \mathrm{MW}, 32 \%$ range from more than $3 \mathrm{MW}$ to $4 \mathrm{MW}$. Turbines with a capacity of more than $4 \mathrm{MW}$ had a share of only $1 \%$ in 2014.

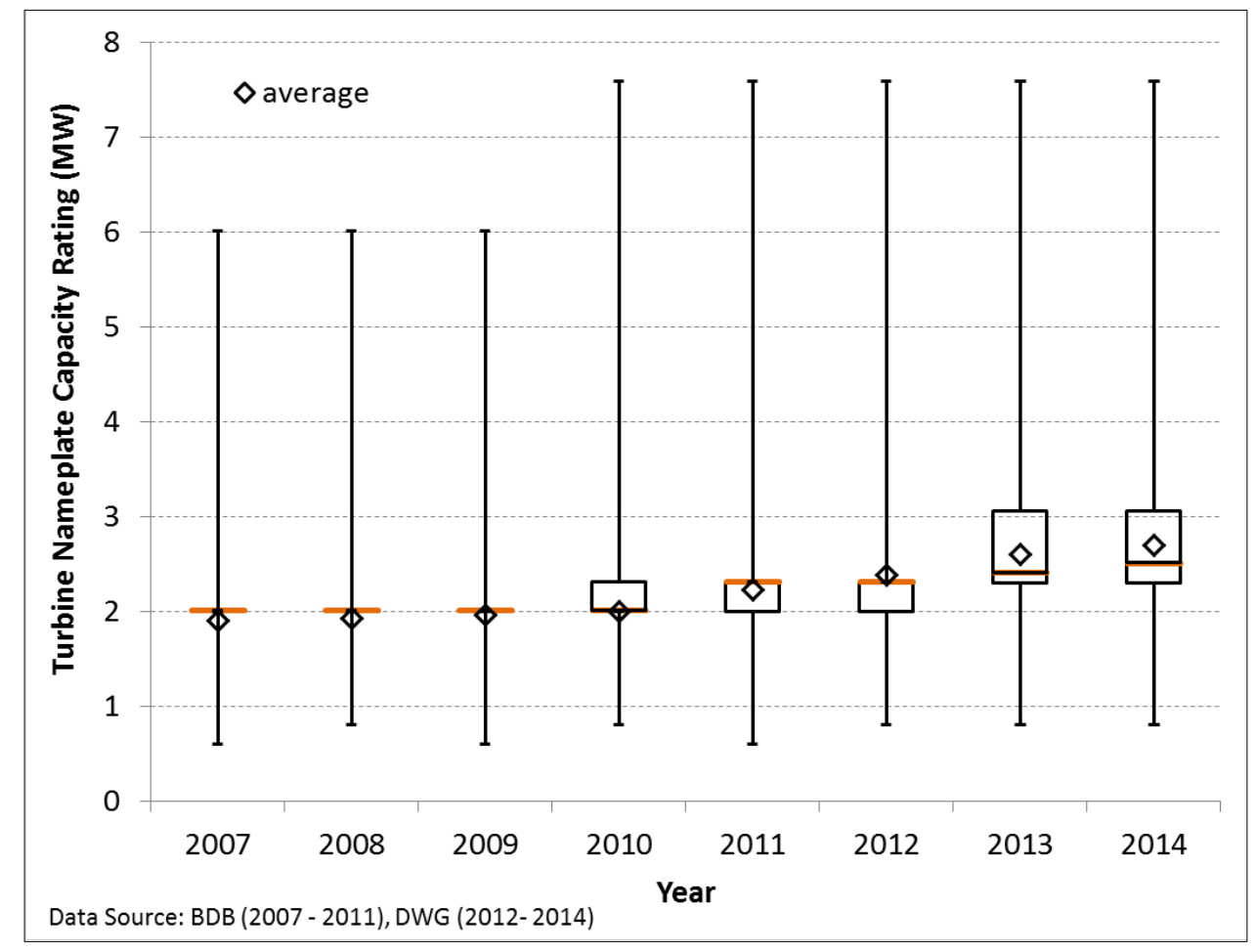

Figure 2-2. Wind turbine nameplate capacity rating trends from 2007 to 2014

The rotor diameter development from 2007 to 2014 demonstrates an increasing trend, which is illustrated in Figure 2-3. While from 2007 to 2009, no significant changes were observed, an obvious increase in the size of rotor diameters occurred in the years after. The average rotor diameter increased from $77.5 \mathrm{~m}$ in 2007 to $88 \mathrm{~m}$ in 2012 and significantly more to $99 \mathrm{~m}$ in 2014 . This is more than a $60 \%$ increase of the average rotor area from 2007 to 2014. Minimum and maximum values correspond to the smallest and largest turbine types in capacity rating.

Rotor diameters have been specifically adjusted to site specifications in Germany. Rotor diameters from $70 \mathrm{~m}$ to $90 \mathrm{~m}$ have been common at coastal sites with good wind resources from 2007 to 2012. A major increase in rotor size came with optimized turbines for lower wind sites, which were seen in installations in 2013. The larger rotors with more than 100-m rotor diameter have been introduced with the 3-MW models. Turbines with larger rotor diameters and lower capacity rating entered the market, especially for low wind sites in central Germany. Models of this trend with rotor diameters above $115 \mathrm{~m}$ have gained prevalence from $2011 \mathrm{on}$. The higher 
specialization for different wind conditions led to better utilization of the available wind energy sites.

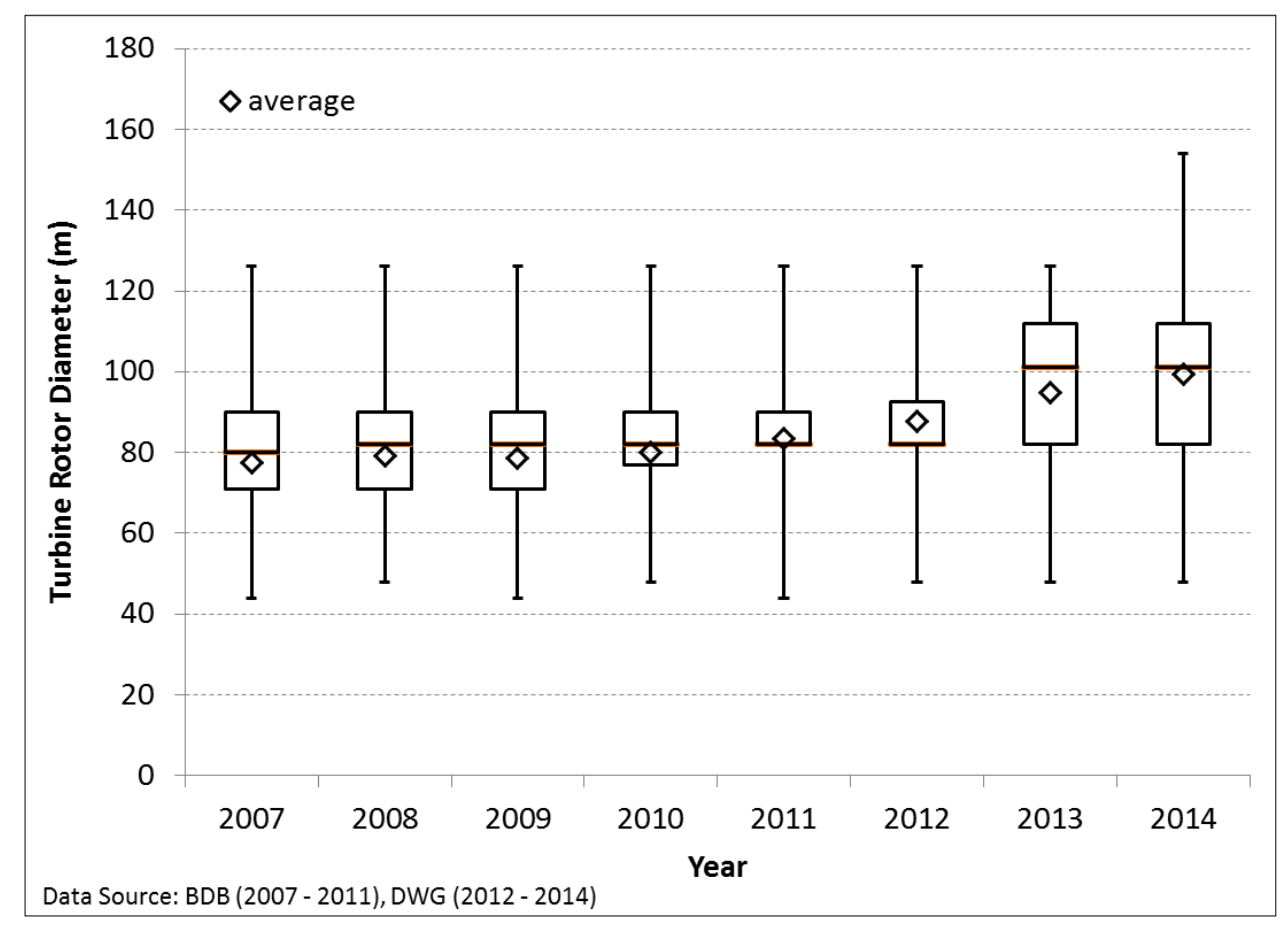

Figure 2-3. Wind turbine rotor diameter trends from 2007 to 2014

As expected, there was a trend of increasing hub heights installed from 2007 to 2014, as shown in Figure 2-4. While the average hub height was $91 \mathrm{~m}$ in 2007, it grew to $111 \mathrm{~m}$ in 2012 and $116 \mathrm{~m}$ in 2014. A slight decrease in hub height can be observed in 2014 because of the strong wind energy development in the very northern German state, Schleswig-Holstein, where turbines of much lower hub height than anywhere else in Germany are installed. The highest lattice tower installed in Germany was erected in 2006 and reaches up to $160 \mathrm{~m}$. Turbines of a specific type are available with different hub height configurations to suit a lot of site requirements. Common configurations in 2013 use steel towers $<100 \mathrm{~m}$ at coastal sites and $>120 \mathrm{~m}$ in the midlands. The highest available towers have heights from $138 \mathrm{~m}$ to $149 \mathrm{~m}$ and are built as steel/concrete hybrids.

In terms of hub height, there are two categories of sites for German wind installations. At coastal sites with high wind resources and low roughness, the towers are smaller compared to sites in forested low mountain regions that are found in the German interior. To exploit higher wind speeds at sites in complex terrain in the German midlands, the hub height of turbines has increased from 2007 to 2014. The general trend to larger turbines with larger rotor diameter adds to this development, because in complex terrain an increased hub height leads to significantly higher wind speeds at rotor level.

The hub heights of turbines installed in Germany depends mainly on the terms of approval. Often such terms are determined within the regional planning. Different regulative authorities and communities have loosened height limits with more recent wind energy planning initiatives. Today, total wind turbine heights of $150 \mathrm{~m}$ up to $200 \mathrm{~m}$ are often approved. In 2014, a so called 
"Länderöffnungsklausel" was implemented. This new law allows German states to set their own rules for distance of wind energy turbines to residential buildings. This might again lead to stronger regulations of turbine heights.

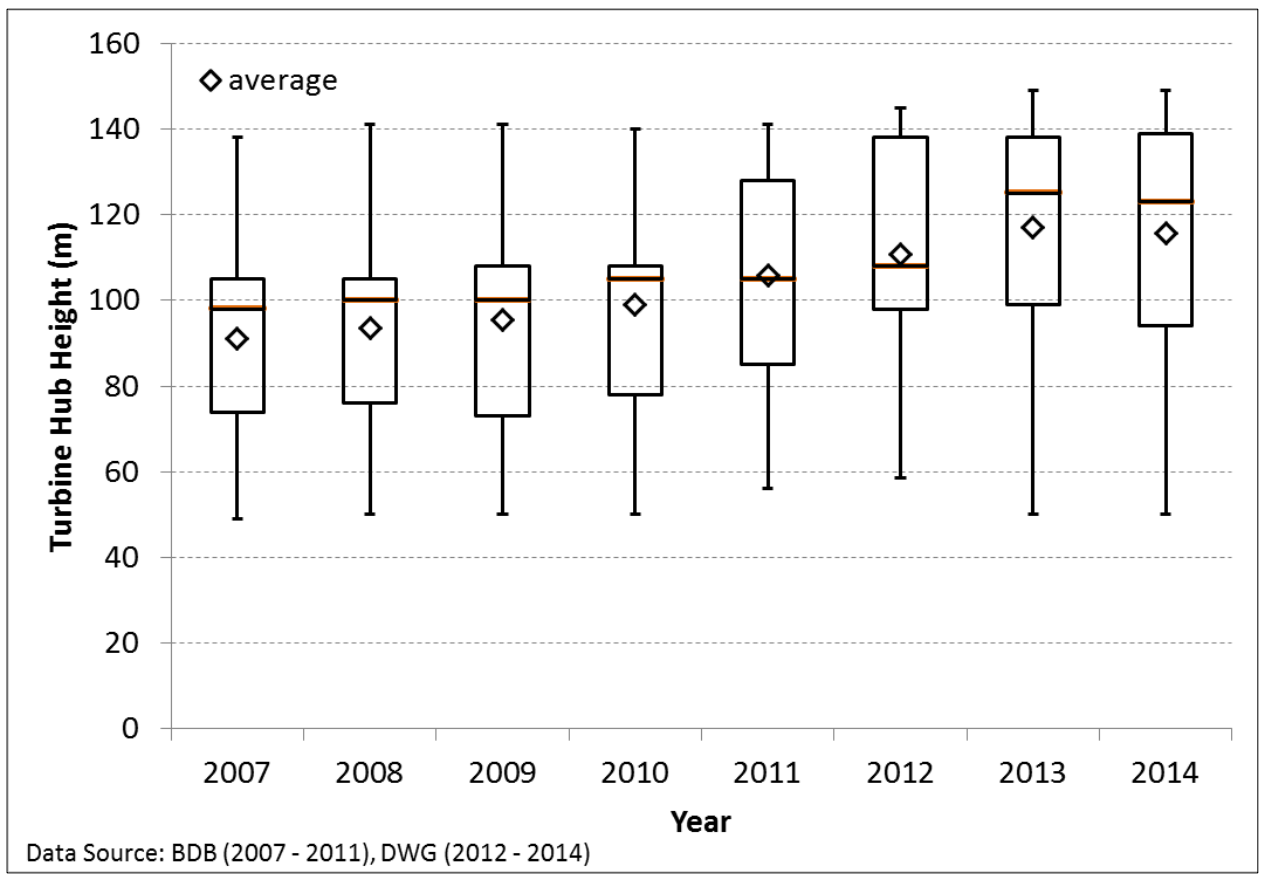

Figure 2-4. Wind turbine hub height trends from 2007 to 2014

The development of specific power of turbines installed in Germany from 2007 to 2014 shows a slight trend toward lower specific power as depicted in Figure 2-5. While from 2007 to 2011 , mean and average values fluctuated, the $75^{\text {th }}$ percentile showed a decrease from 2007 to 2011 . From 2011 to 2014, average and median values started decreasing, as well as the $25^{\text {th }}$ percentile. The notable lowering of minimum values in 2011 was caused by the adaptation of turbine configurations to the needs of low-wind sites in inner Germany.

The full upscaling of turbine configuration to the regular 3-MW Class (higher capacity and higher rotor diameter) leads to slightly lower specific power figures. These turbines are made for high and middle wind speeds (coastal and lowland areas). The trend for low-wind-speed areas, which are available in Germany, is different. Here turbines with larger rotor diameters $(>110 \mathrm{~m})$ and comparably lower capacity $(2.5 \mathrm{MW})$ are used. These turbines are characterized by high efficiency even with low wind speeds (inland sites).

The maximum value is determined by a high turbine capacity per swept rotor area with slightly over 600 watts per square meter $\left(\mathrm{W} / \mathrm{m}^{2}\right)$ for strong wind areas. The lowest specific power turbines installed in Germany with under $225 \mathrm{~W} / \mathrm{m}^{2}$ are specialized low-wind turbines. 


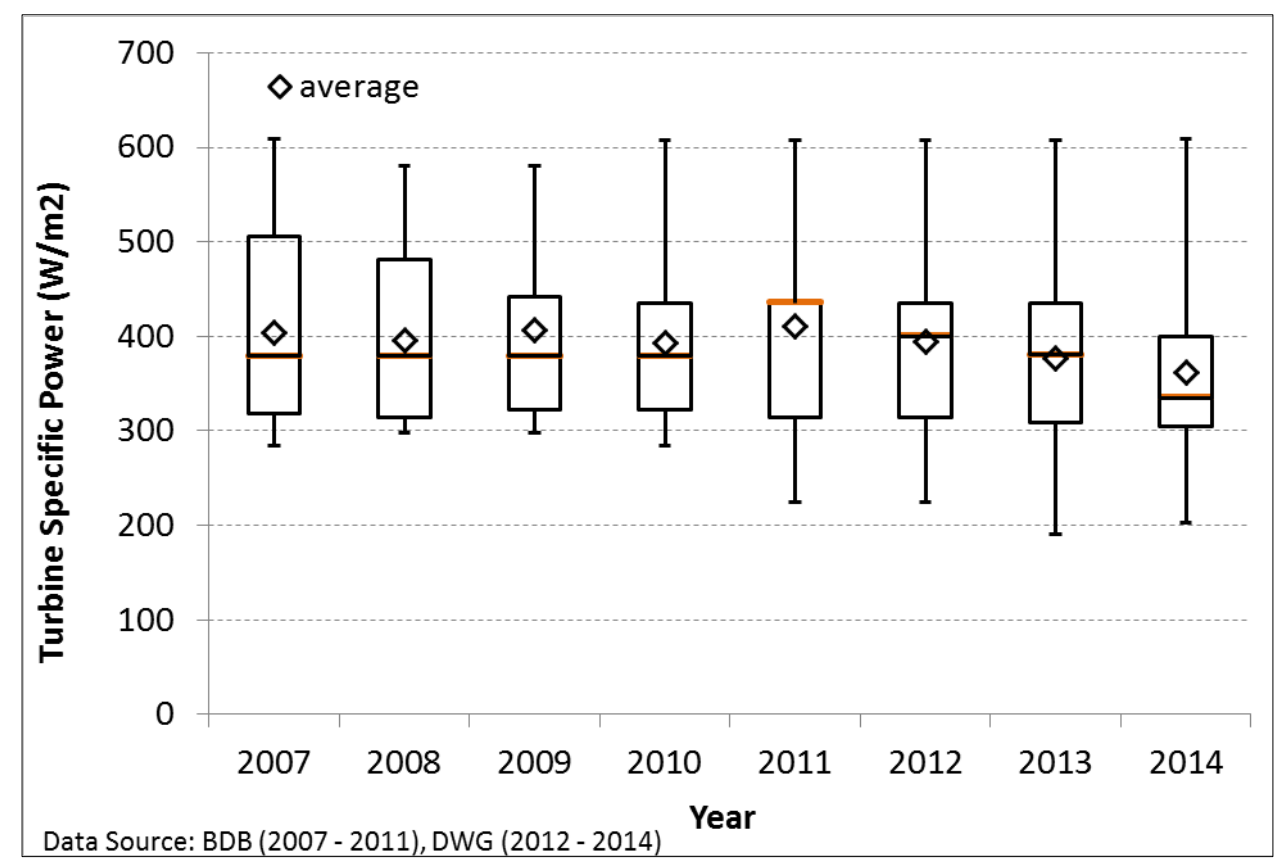

Figure 2-5. Wind turbine specific power trends from 2007 to 2014

In Figure 2-6 shows IEC classes of wind turbines installed from 2007 to first half of 2014. The IEC classification for a wind turbine is specified, in part, by the annual average wind speed for the turbine design. In general, Class I turbines are designed for higher annual average wind speeds than Class III turbines. IEC wind turbine class I/II and II/III apply for turbine models that are available with different wind classes, depending on the hub height.

IEC wind turbine classes installed in Germany have changed from a large share of Class I-II turbines to mainly Class II turbines. The large share of IEC Class I/II and IEC Class II/III turbines is due to the wide range of hub heights offered with a lot of turbines. The same turbine often is certified for a higher wind class when mounted on a lower tower.

On average, turbines installed in Germany are increasingly certified for IEC wind Class II. This is mainly due to changes in the certification of typically installed turbine models. New models certified for IEC wind Class II are being phased in to replace older models certified for IEC wind Class I-II (depending on the hub height). The main 3-MW models for the German market also target the wind Classes II and II-III. Therefore, the proportions may remain similar over the next $3-5$ years.

The share of Class I-II turbines in 2012 and 2013 corresponds with the number of turbines installed at coastal sites within $5 \mathrm{~km}$ of the coast, which is around $20 \%$. The trend to Class II and above turbines also reflects the increasing number of sites that have been developed in lowmountain regions in Germany and have been gaining momentum from 2009 onwards. 


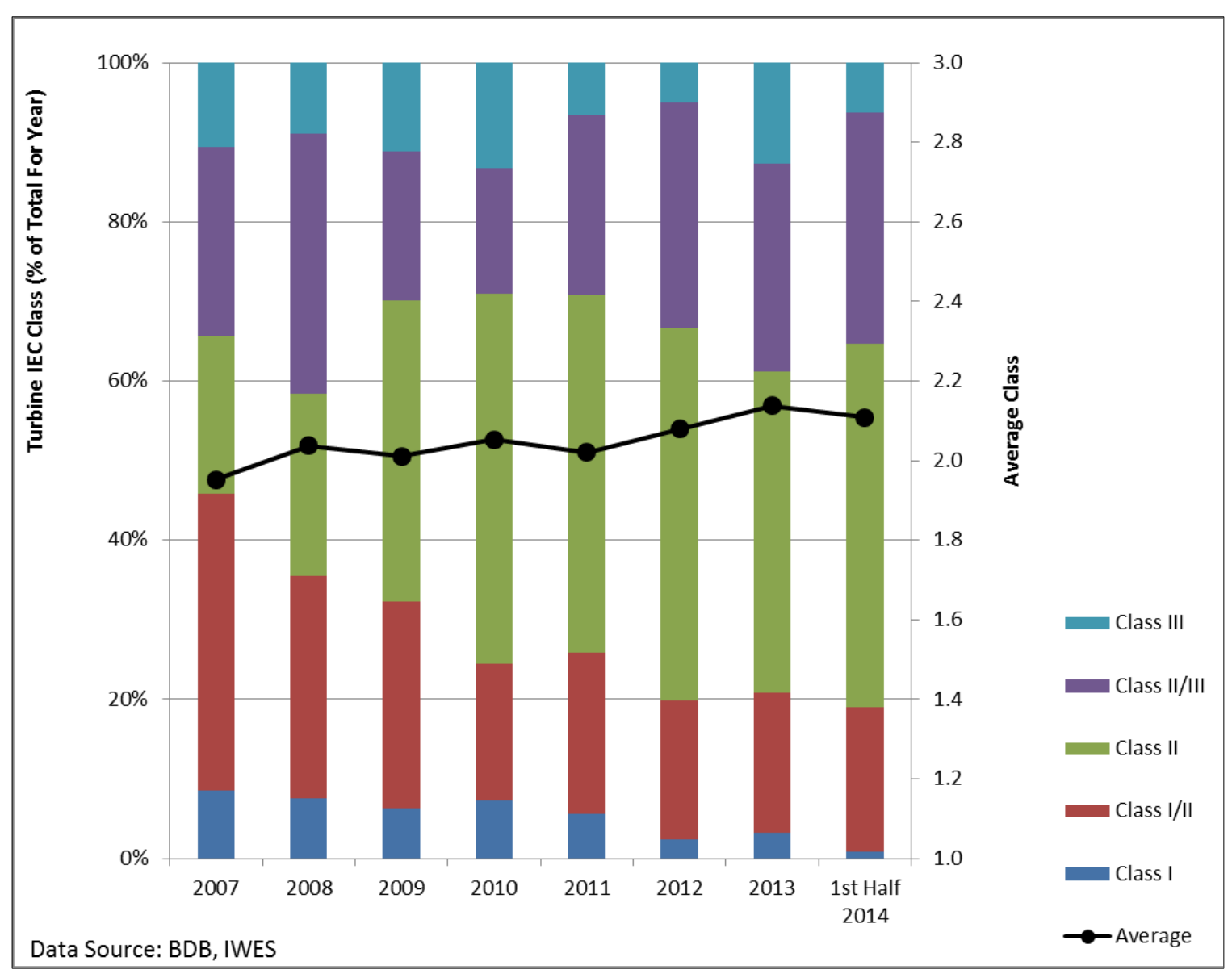

Figure 2-6. Proportion of turbines by IEC class installed in Germany from 2007 to the first half of 2014

\section{Project Performance}

To evaluate the project performance of turbines installed in Germany, various indicators can be investigated. Since annual average wind speed data are not widely available for wind projects in Germany ${ }^{31}$, the focus is on full-load hours and the Germany-specific indicator of site quality. The full-load hours of wind plants based on 2012 production data are used to provide an indication of the performance of projects built between 2007 and 2011. The site quality is a measure within the FIT system in Germany that rates the quality of a wind site based on the fiveyear wind energy yields compared to a calculated generic yield of the turbine with the same height at a reference site with given wind conditions. Both indicators, full-load hours and site quality, are analyzed in the following discussion.

The analysis of the full-load hours of German wind installations suffers due to the lack of good production data sources for turbines installed from 2007 to 2012 and, thus, a very small sample size. This might lead to some distortions. The production data are taken from the year 2012

\footnotetext{
${ }^{31}$ Wind indexes have been calculated for Germany (e.g., by BDB and IWR). For 2012, IWR published a wind energy yield index of $94.2 \%$ for coastal areas and 99.6 for interior areas compared to the preceding ten years. [IWR 2013]
} 
without any index normalization. As site conditions differ a lot throughout Germany, normalization would require a site-specific wind index, which is not available in detail for this analysis. Only turbines with a complete monthly track record in 2012 were analyzed.

Development of typical full-load hours and capacity factor are depicted in Figure 2-7. The capacity factor can be derived from annual full-load hours as it indicates the share of a specific time frame in which a power plant operates at full capacity.

Over the installation years from 2008 to 2010, there was a slight increase in full-load hours and, consequently, capacity factor, driven largely by the higher hub heights of turbines. Full-load hours/capacity factor for inland sites are generally lower than at coastal sites. For the operating year 2012, figures range from an average of about 1,860 to 2,130 full-load hours in the years 2007 to 2012. This equals an average capacity factor from $21 \%$ to $24 \%$. The low-average fullload hours/capacity factor again shows the need for optimized turbine technologies to realize wind energy projects in these conditions. The dip for turbines installed in 2011 may be due to increased operations and maintenance efforts and testing in the first year of operation. The figure may also be affected by statistical effects caused by the small sample size.

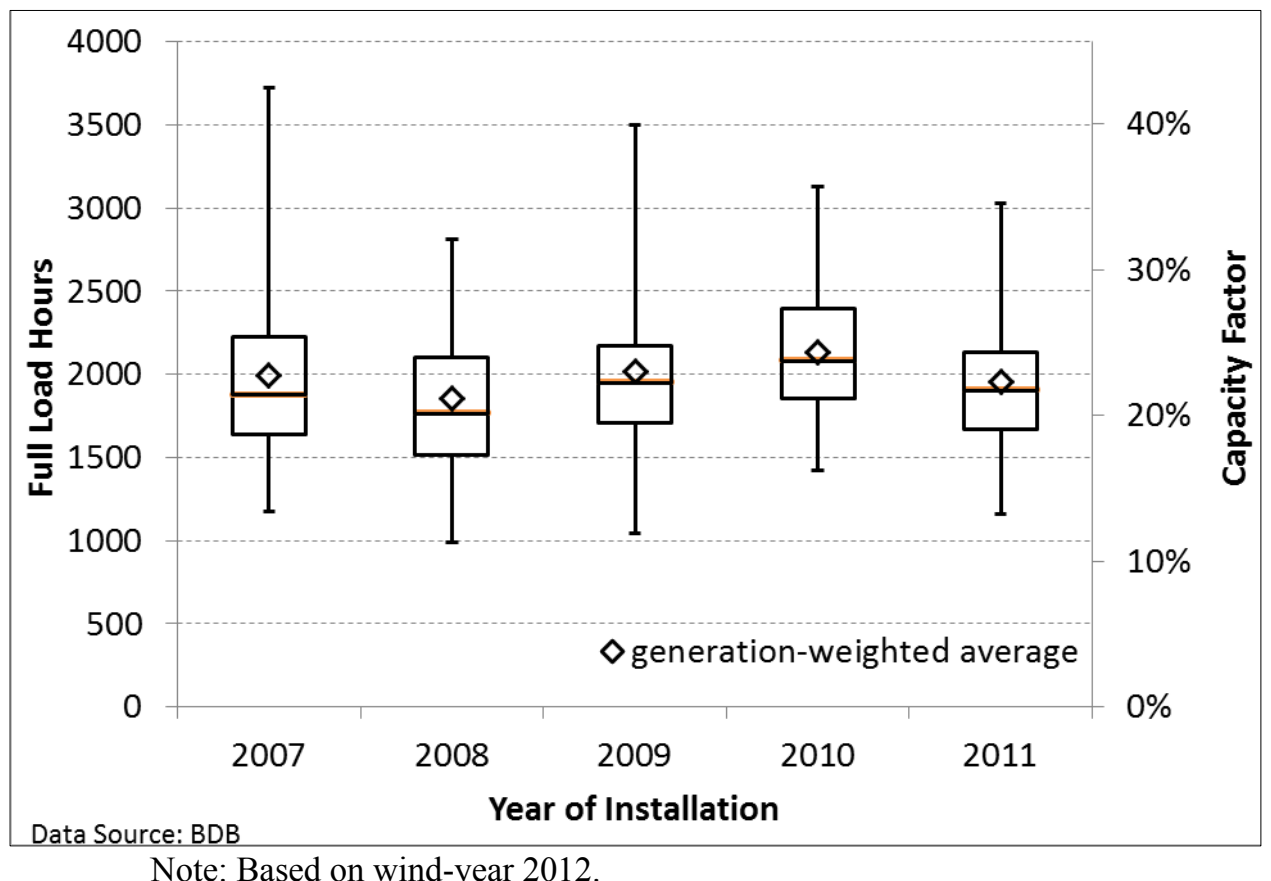

Note: Based on wind-year 2012.

Figure 2-7. Full-load hours/capacity factor for projects installed from 2007 to 2011

The site quality is a performance indicator in the German FIT system. The duration of the higher initial remuneration for wind energy depends on the site quality. Sites with lower winds can profit longer from the initial remuneration. The site quality is calculated by comparing the wind energy production of the first five years to a generic yield for the same turbine at a reference site with given wind conditions. ${ }^{32}$ This figure can be calculated from the turbine models, hub heights, and production data available.

\footnotetext{
${ }^{32} \mathrm{FGW}$
} 
For Figure 2-8, the same data are used as for the full-load hour analysis. The data are unadjusted to a wind index and compared to the reference yield for an average year.

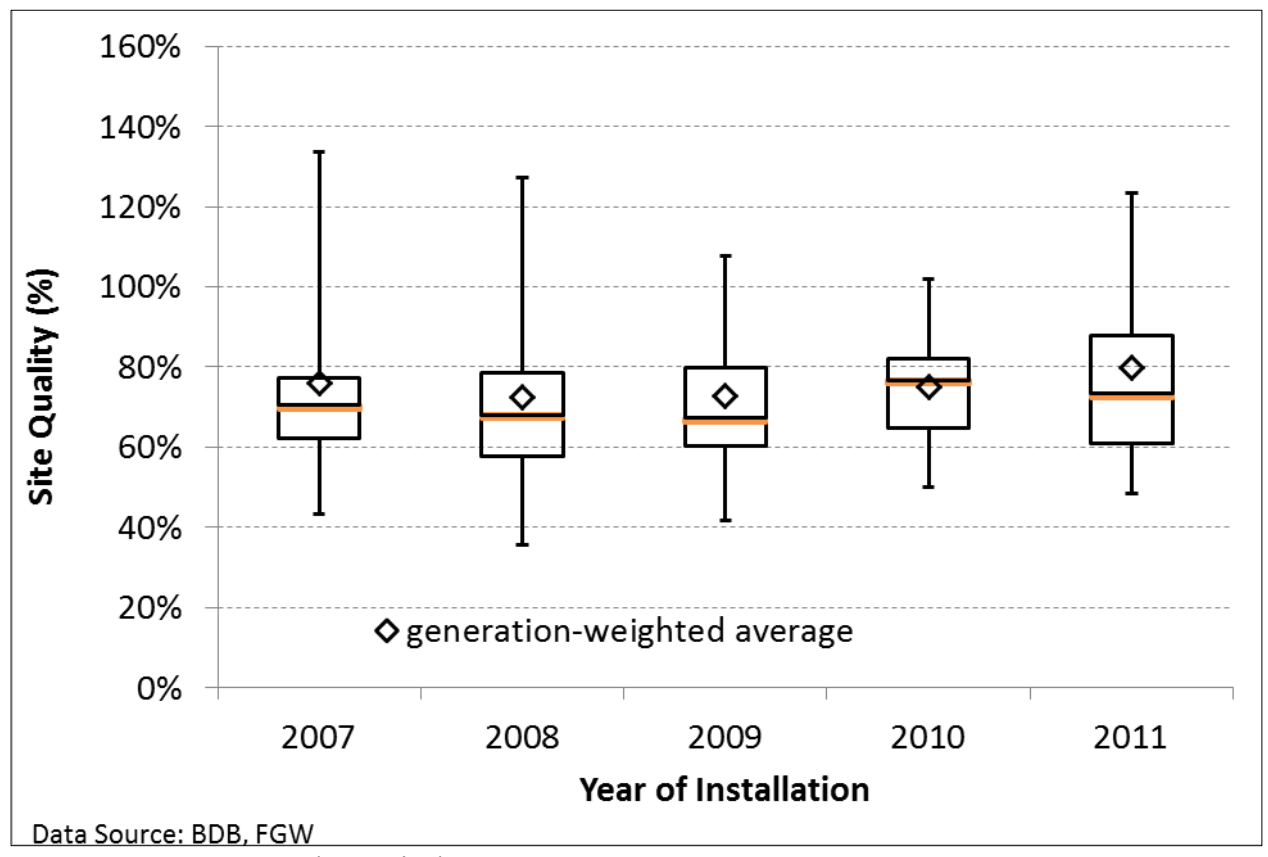

Note: Based on wind-year 2012.

Figure 2-8. Site quality for projects installed from 2007 to 2011

The average wind energy site quality for projects built from 2007 to 2011 is valued between $70 \%$ and $80 \%$. This means that at a typical wind site $70 \%$ to $80 \%$ of the yield of exactly that turbine at a reference site (average annual wind speed of $5.5 \mathrm{~m} / \mathrm{s}$ at a height of $30 \mathrm{~m}$ above ground, a logarithmic wind profile, a roughness length of $0.1 \mathrm{~m}$, and a Rayleigh distribution) is achieved. Most of the wind energy projects are realized at site qualities of 60-90\%, which shows that many sites with comparatively low wind speeds are used.

Due to the small sample size, no obvious trend can be identified and no significant changes in time are observed. In 2007, wind energy development in Germany had also already reached lower wind sites inland. That means the regional distribution of sites did not change in the time frame considered here.

\section{Investment Costs}

The average investment costs for German wind energy projects are depicted in Figure 2-9. Average costs for different turbine configurations are shown by the colored diamonds, the framed diamond represents an average calculated from the annually installed capacity and the average costs of corresponding turbines ${ }^{33}$ (depending on nameplate capacity, hub height, and year of installation).

\footnotetext{
${ }^{33}$ Based on DWG 2008, 2011, and 2013 survey data
} 


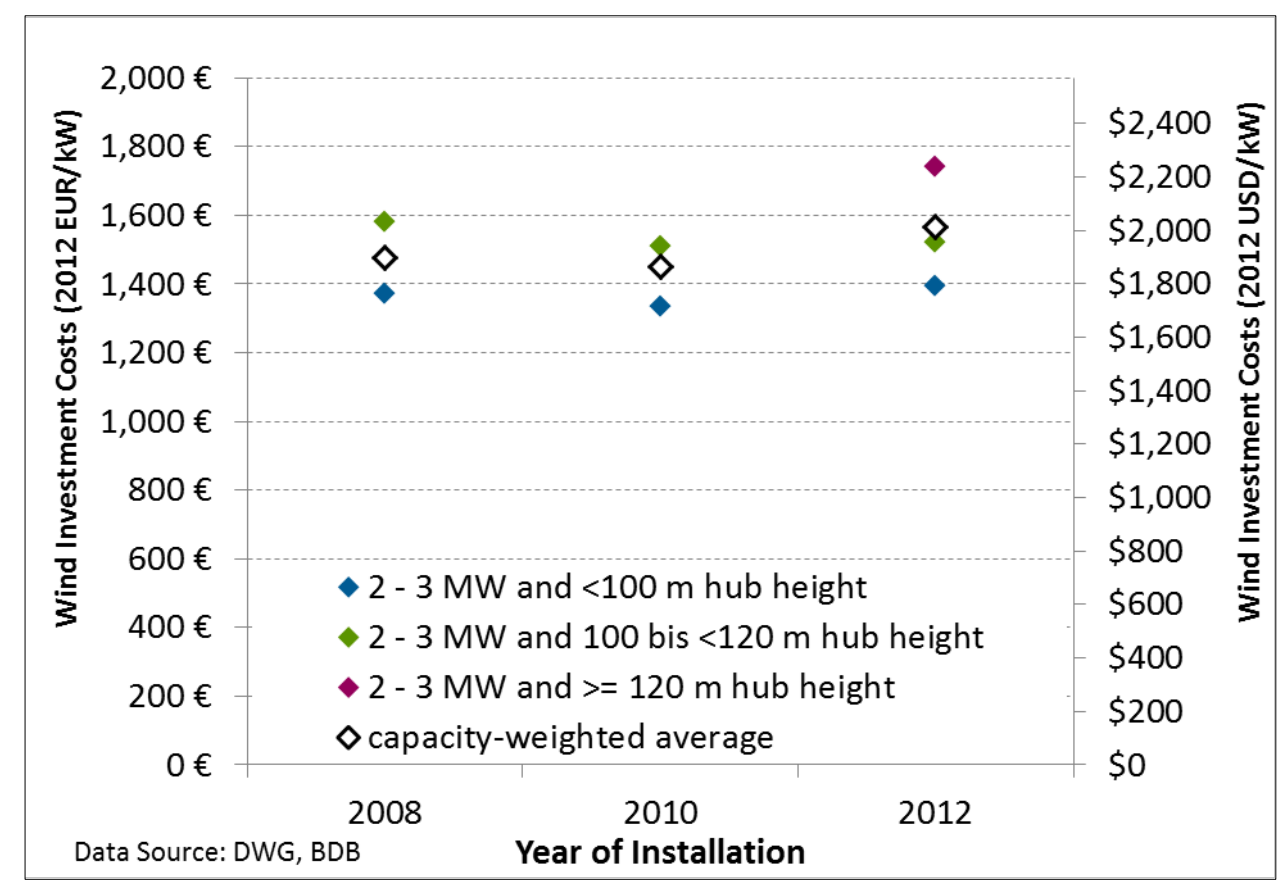

Figure 2-9. Investment costs for projects installed from 2008 to 2012

The investment costs of wind energy projects include the turbine itself, as well as additional costs which occur to achieve a grid-connected, energy-producing wind turbine. The turbine costs, which, besides rotor, nacelle, and tower, include transportation and installation of the turbine, account for about $70-75 \%$ (depending on the turbine configuration) of the investment costs. Looking at typical turbine configurations in Germany (2- to 3-MW) and a hub height of 100 to $120 \mathrm{~m}$ for wind turbines in Germany for the years 2008, 2010, and 2012, average specific turbine costs of about $€ 1,260 / \mathrm{kW}, € 1,130 / \mathrm{kW}$ and $€ 1,150 / \mathrm{kW}$ are observed. ${ }^{34}$

While costs per kilowatt dropped from 2008 to 2010 by $10 \%$, they grew again by $2 \%$ from 2010 to 2012. The recent, rather unpleasant development can be qualified by looking at the costs per square meter swept rotor area. In Germany, sites with comparatively low wind speeds are increasingly used for wind energy development, and optimized turbine types for these meteorological conditions have been developed. In particular, rotor diameters have been growing significantly in recent years. Therefore, the costs per square meter of swept rotor area are the more important indicators for evaluating wind energy costs in Germany, which decreased from 2008 to 2012. A 2- to 3-MW turbine with a hub height of 100 to $120 \mathrm{~m}$ cost about $€ 470 / \mathrm{m}^{2}$ in 2008 and $€ 390 / \mathrm{m}^{2}$ on average in 2012. Similar development can be surveyed for turbines with hub heights below $100 \mathrm{~m}$, whereby costs increase with the hub height.

Twenty-five to $30 \%$ of the investment costs are additional costs. They amount to about $€ 320 / \mathrm{kW}$ in $2008, € 380 / \mathrm{kW}$ in 2010 and $€ 370 / \mathrm{kW}$ in 2012 on average. They consist of foundation costs, grid connection costs, infrastructure costs, planning costs, and other costs.

\footnotetext{
${ }^{34}$ All $€$ values in this and following chapters are inflation-adjusted to $2012 €$.
} 
On average, $25 \%$ of the additional costs are planning costs. The typical planning period for German land-based wind energy projects is about three to five years. Planning costs include building permissions and various expert reports. Twenty percent of the additional costs are needed for internal plant cabling and grid connection. In Germany, the connection to the grid connection point is paid for by the wind plant developer. The grid connection point is the closest or economically most reasonable access point to the grid. Any necessary strengthening of the grid itself is paid for by the TSO and is not included in the data. Eighteen percent of the additional costs go to the foundation, and $11 \%$ are used to build up the infrastructure. The last $26 \%$ of other additional costs are very project-specific and may contain different types of costs like costs for compensation areas as an adequate alternative for encroachments in the environment at the project site, for example. In conclusion, it should be noted that additional costs have a wide project-specific range due to a lot of project-specific factors.

\section{Operations and Maintenance Costs}

In Figure 2-10, O\&M costs are represented as average values for the first and the second decade of a turbine's operational lifetime. ${ }^{35}$ Due to increased maintenance and repair for wind turbines after several years of operation, O\&M costs are higher in the second decade of operation.

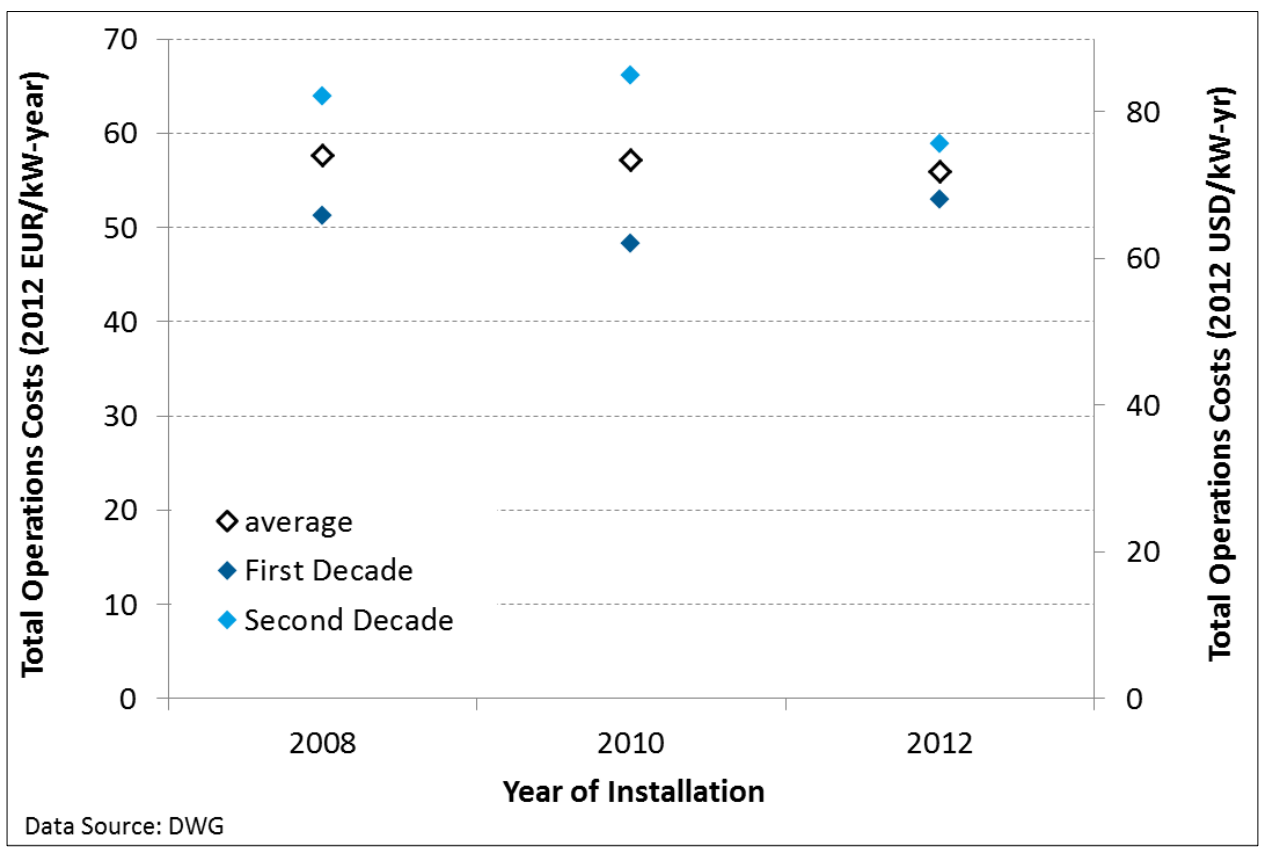

Figure 2-10. O\&M costs in the first year of operation for projects installed from 2008 to 2012

O\&M costs include maintenance and repair, land lease, technical and commercial administration, insurance, reserves for contingencies and dismantling, and other operational costs. They amount to $€ 57.6 / \mathrm{kW}$ in $2008, € 57.2 / \mathrm{kW}$ in 2010 , and $€ 55.9 / \mathrm{kW}$ in 2012 . The largest shares of the O\&M costs are the maintenance and repair costs. Depending on the decade of operation, on average 44 to $55 \%$ of the O\&M costs are paid for maintenance contracts which are, in general, provided by the turbine manufacturers. Survey results for the year 2012 show that most of the project

\footnotetext{
${ }^{35}$ Based on project developer estimates for operation costs for first and second decade of turbine operational time as in DWG 2008, 2011, and 2013 survey data
} 
developers use full maintenance contracts (98\% of 59 projects). With 19 to $22 \%$ of the O\&M costs, land lease is another expensive position. Technical and commercial administration is responsible for 13 to $17 \%$ of the O\&M costs. Insurance, reserves for contingencies and dismantling and other operational costs have a share of 3 to $8 \%$ each.

\section{Financing Costs}

Most of the German land-based wind energy projects are funded by project financing. Financing Costs result from share of equity and debt, as well as the underlying rate of return and interest rate. In Germany, with the first release of the EEG, the financial risk of wind energy project development became relatively low, and the share of equity was as low as $30 \%$ in 2008 and $22 \%$ in 2012 . The average share of debt is about $70 \%$ for a typical wind energy project in 2008 , and $78 \%$ for 2012 projects. The further increase of the debt share is related to the effects of the financial crisis and the decreasing key interest rate. Wind energy projects in Germany have been relatively safe and rentable investments.

The rate of return can be assumed to be between $8.75 \%$ and $11.0 \%$ in 2012 . The interest rate of debt, which was about 5.5\% in 2007, sank to about $3.8 \%$ on average according to project developers. Bankers and the development of the interest rate of $\mathrm{KfW}$ loans (special condition loans for renewable energy projects) confirm these numbers. Average wind energy financing terms are indicated in Table 2-2.

Table 2-2 Typical Wind Energy Financing Terms in Germany

\begin{tabular}{|l|l|r|r|r|}
\hline & & 2008 & $\begin{array}{c}2012 \\
\text { Coastal Site }\end{array}$ & $\begin{array}{c}2012 \\
\text { Inland Site }\end{array}$ \\
\hline Return on equity & $\%$ & 9.5 & 9.75 & 9.0 \\
\hline Return on debt & $\%$ & 5.5 & 3.6 & 3.6 \\
\hline Equity share & $\%$ & 30 & 22 & 22 \\
\hline Debt share & $\%$ & 70 & 78 & 78 \\
\hline Loan duration & (years) & 13 & 16 & 16 \\
\hline Corporate tax rate & $\%$ & 29.8 & 29.6 & 29.6 \\
\hline FX rate & $(\mathrm{US} \$ / €)$ & 1.39 & 1.28 & 1.28 \\
\hline WACC (after tax, nominal) & $\%$ & 5.6 & 4.1 & 4.0 \\
\hline
\end{tabular}

The high share of debt, which results from low risks due to EEG regulations is not taken into account as policy incentive due to lack of data. Assumptions about how share of debt and equity would level off without EEG regulation have not been made.

Revenue is generated from the feeding of electric energy from the turbine to the grid and the related tariff in the year of turbine installation. For turbines installed in 2007, the initial tariff was $€ 81.9 / \mathrm{MWh}$, and the basic tariff was $€ 51.8 / \mathrm{MWh}$. Turbines installed in 2012 receive an initial tariff of $€ 89.3 / \mathrm{MWh}$ plus the ancillary services bonus of $€ 4.8 / \mathrm{MWh}$ and a basic tariff of $€ 48.7 / \mathrm{MWh}$. Compared to 2007, the initial bonus increased while the basic tariff decreased. Since the claim duration for the initial tariff depends on the site quality (a low-wind site leads to a longer duration of claim of the initial tariff), the prolongation of tariffs gives an advantage to interior low-wind sites, which are typical for Germany. Further details on the EEG are given in the section titled Revenue and Policy Incentives. 


\section{Cost of Wind Energy Generation in Germany in 2008 and 2012}

The calculation of levelized cost of energy (LCOE) is used to represent lifetime cost of energy generation for different technologies and framework conditions. In this case, LCOE for wind energy projects in Germany in 2008 and 2012 is calculated with a cash flow model. ${ }^{36}$ To ensure the comparability to other countries within this study, the ECN model is used, even though similar analyses have been made for Germany before (DWG 2008, DWG 2011, and DWG 2013) with similar (not identical) input parameters by application of a net-present-value method base model, which leads to slightly different outputs.

\section{Representative Wind Energy Projects in 2008 and 2012}

A rather good average wind site was chosen to reflect a German wind energy project in $2008 .{ }^{37}$ The analyzed wind project has a site quality ${ }^{38}$ of $90 \%$ of the reference yield. In 2012 , due to the wide-ranging site specifics found in Germany (from coastal sites in Lower Saxony and Schleswig-Holstein to low-wind sites in the rangy woodlands of inland sites in mid and south Germany), two different sites are chosen. The first site is a coastal site with a site quality of $100 \%$. Better sites are available but very rare. The second site reflects an average inland site with a site quality of $70 \%$. Sites like this can be found all over Germany and reflect, compared to other countries, the special low-wind conditions German wind energy developers have to face. As explained before, the German revenue incentive system takes this into account and offers better revenues to low-wind sites to enable inland wind energy development. The aim with this approach is to alleviate the concentration of wind energy development in the northern regions of Germany.

The chosen model projects reflect the technology and cost status of 2012. Analyzing the technology trends after 2012, development of higher turbines with larger rotor diameter and lower specific power is observed. This change in project features led to a higher efficiency of turbines at similar wind sites. Optimized turbines reach more full-load hours and a more stable energy output. This has a cost-cutting effect on wind energy projects. A contrary effect may result from the cost side, as larger turbines (hub height and rotor diameter) are expected to be more expensive. Due to the lack of 2014 cost data, an LCOE analysis of a typical 2014 project is not included in this report.

Model Input Assumptions In the following, the modeling assumptions ${ }^{39}$ used in the LCOE analyses are presented. For project features, see Table 2-3. Policies are noted in Table 2-4.

\footnotetext{
${ }^{36}$ The cash flow model for LCOE calculations was developed by ECN to be used in IEA wind Task 26 (Schwabe et al., 2011)

${ }^{37}$ Scenario as in IEA 2011 (Schwabe et al., 2011)

${ }^{38}$ Site quality as defined in EEG (see the Chapter 2, Development of Revenue and Policy Incentives)

${ }^{39}$ All input parameters are shown in $2012 €$.
} 
Table 2-3. Wind Energy Project Features in Germany

\begin{tabular}{|l|l|r|r|r|}
\hline & & 2008 & $\begin{array}{c}2012 \\
\text { Coastal Site }\end{array}$ & $\begin{array}{c}2012 \\
\text { Inland } \\
\text { Site }\end{array}$ \\
\hline Unit size & $\mathrm{MW}$ & 2 & 2.5 & 2.5 \\
\hline Number of turbines & $\mathrm{N}$ & 5 & 4 & 3 \\
\hline Rotor Diameter/hub height & $\mathrm{m} / \mathrm{m}$ & $75 / 100$ & $90 / 110$ & $100 / 130$ \\
\hline Site quality & $\mathrm{m} / \mathrm{s}$ & $90 \%$ & $100 \%$ & $70 \%$ \\
\hline Production & $($ full-load hours) & 2,260 & 2,880 & 2,220 \\
\hline Economic life & $($ years $)$ & 20 & 20 & 20 \\
\hline Investment costs & $\left(€_{2012} / \mathrm{kW}\right)$ & 1,440 & 1,590 & 1,780 \\
\hline O\&M costs fixed & $\left(€_{2012} / \mathrm{kW}\right)$ & 48.7 & & \\
\hline Average O\&M costs variable & $\left(€_{2012} / \mathrm{kWh}\right)$ & & 2.5 & 2.5 \\
\hline Decommission costs & $\left(€ \mathrm{ct}_{2012} / \mathrm{kWh}\right)$ & 1.6 & & \\
\hline WACC (after tax, nominal) & $\%$ & 5.6 & 4.1 & 4.0 \\
\hline Corporate tax rate & $\%$ & 29.8 & 29.6 & 29.6 \\
\hline
\end{tabular}

Table 2-4. Wind Energy Policy and Revenue Incentives in Germany

\begin{tabular}{|c|c|c|c|c|}
\hline & & 2008 & $\begin{array}{c}2012 \\
\text { Coastal } \\
\text { Site }\end{array}$ & $\begin{array}{l}2012 \\
\text { Inland } \\
\text { Site }\end{array}$ \\
\hline Market price electricity & $\begin{array}{l}€_{2012} / \mathrm{MW} \\
\mathrm{h}\end{array}$ & - & - & - \\
\hline Average FIT revenue & $\begin{array}{l}€_{2012} / \mathrm{MW} \\
\mathrm{h}\end{array}$ & 82 & 81 & 89 \\
\hline FIT policy period & (years) & 20 & 20 & 20 \\
\hline Upfront tax-based subsidy before tax & $\%$ & & - & - \\
\hline Production-based before tax credits & $€ /$ kWh & & - & - \\
\hline Production-based before tax credit policy period & (years) & & - & - \\
\hline Depreciation period & (years) & 16 & 16 & 16 \\
\hline Reactive power bonus & $\epsilon_{2012} / \mathrm{kWh}$ & - & - & - \\
\hline Ancillary services bonus (incl. low voltage ride through) & $\begin{array}{l}\epsilon_{2012} / \mathrm{MW} \\
\mathrm{h}\end{array}$ & - & 3.9 & 4.8 \\
\hline Market certificates & $€_{2012} / \mathrm{kWh}$ & - & - & - \\
\hline
\end{tabular}

Due to analytic reasons and data availability, the application of the FIT model from the EEG 2012 (non-direct marketing) has been assumed, even though about $80 \%$ of the wind energy produced uses direct marketing as of the end of 2012. ${ }^{40}$ The sum of revenue, FIP, and management bonus might be slightly different, but this is case-specific and depends on the direct marketing contracts held by a wind plant operator.

The average FIT for 2012 includes the ancillary services bonus because the fulfillment of ancillary services requirements is compulsory.

${ }^{40}$ IWES 2013 


\section{LCOE, Policy Incentives, and Required Revenue}

By applying the cash flow model on the input parameter defined above, LCOE for each site and year is calculated. ${ }^{41}$ The LCOE is compared to the value of the policy by also showing the deviation between the values in Table 2-5 and Figure 2-11. LCOE can be directly compared to the EEG revenue. LCOE, EEG-revenue (FIT + bonus), and the deviation between these values are displayed in Table 2-5 for the three model cases.

The red bar shows the deviation between levelized cost of energy and EEG revenue. Projects with a deviation have a financial gap and can only be conducted with reduced return on investment compared to the model case. If the EEG-revenue is higher than the levelized cost of energy in the model case, no financial gap exists. In the figure, this is shown by a negative deviation, which means the return on investment is higher than the assumed value in the model case. All assumptions are based on average values; results reflect averages as well.

Table 2-5. Wind Plant LCOE Summary with Policy and Revenue Components

\begin{tabular}{|l|l|r|r|r|}
\hline & & 2008 & 2012 & 2012 \\
& & & Coastal Site & $\begin{array}{c}2012 \\
\text { Inland Site }\end{array}$ \\
\hline Levelized cost of energy & $\left(€ \mathrm{ct}_{2012} / \mathrm{kWh}\right)$ & 89 & 75 & 97 \\
\hline EEG-revenue & $\left(€ \mathrm{ct}_{2012} / \mathrm{kWh}\right)$ & 83 & 90 & 94 \\
\hline Deviation & $\left(€ \mathrm{ct}_{2012} / \mathrm{kWh}\right)$ & 6 & -15 & 3 \\
\hline
\end{tabular}

The levelized cost of energy generated in a typical 2008 project on average could not be financed without reducing the expected return on investment of the site for the project developer. By 2012, the situation changed. On average projects at good coastal sites obtained a surplus due to the lowered cost. Even turbines at inland sites with lower wind conditions obtained economic efficiency, with only a minor deviation between LCOE and EEG-revenue.

The main reasons for the good economic feasibility in 2012 besides an increased FIT (plus a bonus) are higher utilization rates of the wind turbines and the reduction of financing cost. A high share of debt with very low return on debt has led to a comparably low WACC. The EEG support rates are fixed in the EEG amendment which applies to the specific wind energy project based on its commissioning date. They are not amended steadily but are dependent on the development of financing conditions or inflation rate.

As can be expected, good wind sites are more profitable than low-wind sites. The design of the EEG (additional support of low-wind sites by reference site model) aims at enabling wind energy development in German inland. Nevertheless, the EEG consciously grants higher profitability for high-wind sites to ensure economically efficient wind energy development.

${ }^{41}$ Compare with Appendix 1 Methodology 


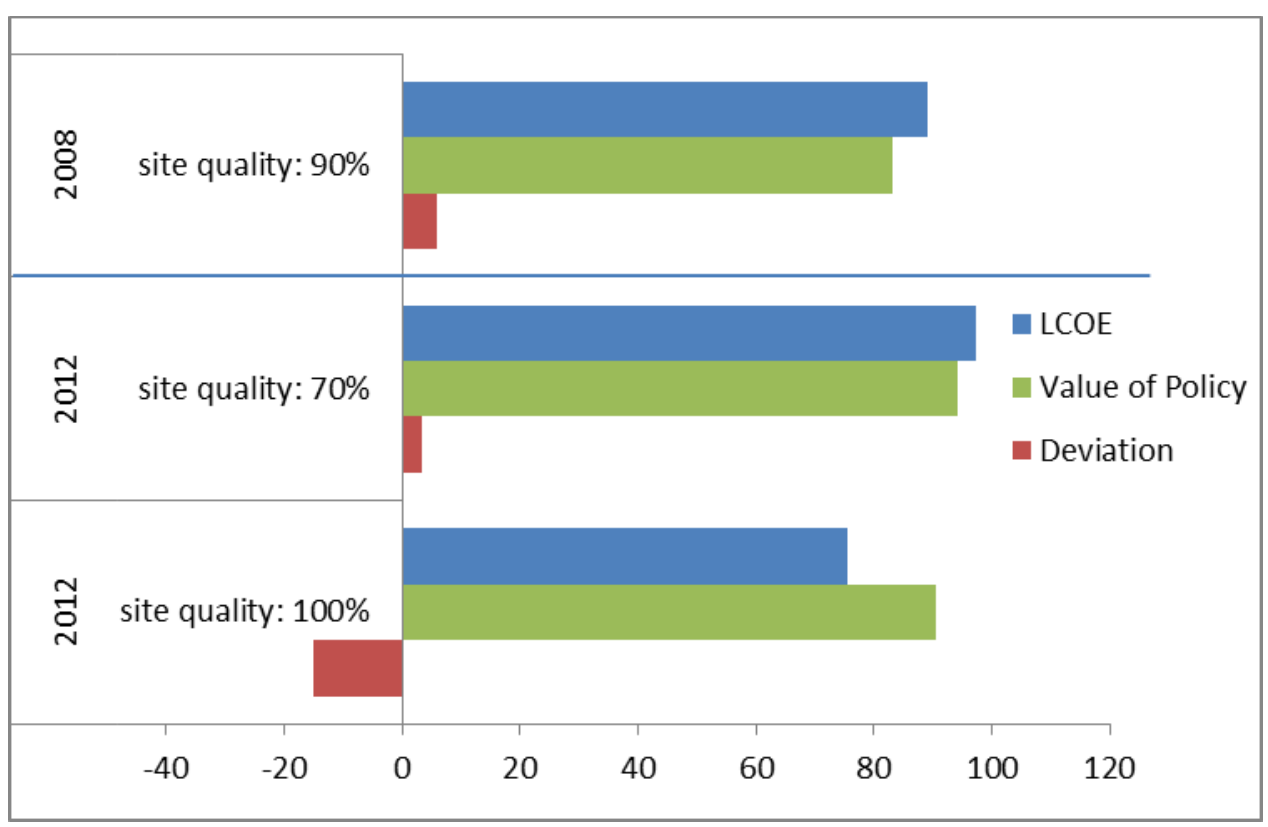

Figure 2-11. Wind energy revenue and policy incentives in Germany at a typical site in 2008 and at coastal and inland wind sites in 2012

\section{Summary of Wind Projects in Germany 2008 to 2014}

From 2008 to 2014, several trends in wind energy development are identified. The turbine capacity, as well as rotor diameter and hub height, grew from 2008 to 2014. The turbines became more efficient and are able to deliver ancillary services. Due to the higher utilization rates, lower cost of financing, and other effects, increased investment cost did not lead to increased LCOE.

The LCOE depends heavily on the site quality of the turbine location. LCOE is much lower if a high capacity factor can be achieved. The average LCOE of wind energy projects in Germany therefore depends strongly on the distribution of wind energy development across the country.

The EEG revenue (FIT + bonus) increased from 2008 to 2012 because of higher requirements for turbine capabilities concerning ancillary services. High FIT and reduced financing costs led to good profitability of 2012 wind projects (especially for medium and good wind sites with from $80 \%$ to $130 \%$ site quality).

The FIT defined in the renewable energy law (EEG) is not bound to the development of interest rates, etc. Therefore, updating the law on regular basis is necessary. The latest amendment of the EEG not only affected the value of FIP (FIT is no longer available for new wind energy projects) but also changed the embodiment of the site-differentiated incentive methodology. The new design aims to reflect the cost structure in a more realistic way, support inland sites, and grant good profitability to good coastal wind sites considering the utilization of optimized technologies. 


\section{References for Chapter 2}

BDB Betreiber-Datenbasis: Database on German wind turbines (installation, configuration, production, etc.) since 1988

BDEW Energie-Info Bundesverband der Energie- und Wasserwirtschaft e.V.: Erneuerbare Energien und das EEG: Zahlen, Fakten, Grafiken (2014). Berlin 2014

Destatis Statistisches Bundesamt: www.destatis.de. last access September 2014

DWG 2008

Deutsche WindGuard (Rehfeldt, Wallasch): Vorbereitung und Begleitung der Erstellung des Erfahrungsberichtes 2007 gemäß § 20 EEG - Kapitel 6 Stromerzeugung aus Windenergie. 2008

DWG 2011 Deutsche WindGuard (Rehfeldt, Wallasch, Wallasch): Vorbereitung und Begleitung der Erstellung des Erfahrungsberichtes 2011 gemäß § 65 EEG - Vorhaben IIe Windenergie. 2011

DWG 2012ff Deutsche WindGuard (Lüers, Rehfeldt, Rehfeldt, Wallasch): Status of Land-Based and Offshore Wind Energy Development in Germany.

Published semiannually since 2012

DWG 2013 Deutsche WindGuard (Wallasch, Lüers, Rehfeldt, Ekkert):

Kostensituation der Windenergie an Land in Deutschland. 2013

DEWI DEWI Magazin No. 40, C. Ender; DEWI GmbH: Wind Energy Use in Germany Status 31.12.2011. 2012

EC $2014 \quad$ European Commision: Official Journal of the European Union: Guidelines on State aid for environmental protection and energy 2014-2020 (2014/C 200/01). 2014

EEG $2004 \quad$ Deutscher Bundestag: Erneuerbare-Energien-Gesetz vom 21. Juli 2004 (BGB1. I S. 1918). 2004

EEG 2009 Deutscher Bundestag: Erneuerbare-Energien-Gesetz vom 25. Oktober 2008 (BGBl. I S. 2074). 2008

EEG 2012 Deutscher Bundestag : Erneuerbare-Energien-Gesetz vom 25. Oktober 2008 (BGB1. I S. 2074), zuletzt geändert durch Artikel 1 des Gesetzes zur Änderung des Rechtsrahmens für Strom aus solarer Strahlungsenergie und zu weiteren Änderungen im Recht der erneuerbaren Energien vom 17. August 2012 (BGB1. I S. 1754). 2012

EEG 2014 Deutscher Bundestag: Erneuerbare-Energien-Gesetz vom 21. Juli 2014 (BGBl. I S. 1066). 2014

FGW Fördergesellschaft Windenergie: Lists of reference wind energy yields for turbines, www.wind-fgw.de/eeg referenzertrag.htm. 2014

IEA $2011 \quad$ IEA wind Task 26 (Leading authors: Schwabe, Lensink, Hand): IEA Wind Task 26 - Multi-National Case Study of the Financial Cost of Wind Energy. 2011

IWR 2013 Internationales Wirtschaftsforum Regenerative Energien (IWR): Der IWR-Windertragsindex ${ }^{\circledR}$ für Regionen - 10-jähriger Index 2012. 01/2013 

(IWES): Wind energy report 2012. 2013

IWES $2014 \quad$ Fraunhofer institute for wind energy and energy system technology (IWES): Wind energy report 2013. 2014

Schwabe, P.; Lensink, S.; Hand, M. (2011). IEA Wind Task 26 - Multi-national Case Study of the Financial Cost of Wind Energy; Work Package 1 Final Report. 122 pp.; NREL Report No. TP-6A20-48155.

\section{Appendix 2-A Sample Size and Project Data for Germany}

This appendix contains statistics representing wind project characteristics that are illustrated in the chapter. Table 2-6 describes the sample size of data represented in the subsequent tables. The values in the table correspond to the installed wind project capacity in a given year, or the percentage of annual installed capacity, that is included in the database. For example, an entry of $100 \%$ for Wind Turbine Hub Height means that the statistics shown in the corresponding table and figure for hub height represent $100 \%$ of the turbines installed in that year. 
Table 2-6. Definitions and Sample Size for Germany

COUNTRY: Germany

DEFINITION OF UTILTY SCALE WIND

All land-based wind projects equal to or over $500 \mathrm{~kW}$ in size; with all turbines in the project also equal to or over $500 \mathrm{~kW}$.

YEAR DATA AGGREGATION

Cost data has been taken DWG wind energy cost analyses based on survey results. (DWG 2008, 2011 and 2013)

\section{OTHER NOTES}

Sample size may exceed $100 \%$ due to slight difference between databases used for analysis. Total Wind Power Additions are based on DWG statistics.

Wind Project Size, Annual Average Wind Speed, Cost: insufficient data for "box \& whiskers" chart.

\begin{tabular}{|c|c|c|c|c|c|c|c|c|}
\hline \multirow[t]{2}{*}{ SAMPLE } & \multicolumn{8}{|c|}{ Capacity (Megawatts) } \\
\hline & 2007 & 2008 & 2009 & 2010 & 2011 & 2012 & 2013 & 2014 \\
\hline \multicolumn{9}{|c|}{ Annual Installations -- Land-Based, Utility-Scale Only } \\
\hline Total Wind Power Additions & 1,667 & 1,652 & 1,856 & 1,433 & 1,942 & 2,324 & 2,998 & 4,750 \\
\hline \multicolumn{9}{|l|}{ Sample Size -- Land-Based, Utility-Scale Only } \\
\hline Wind Project Size & - & - & - & - & - & - & - & - \\
\hline Wind Turbine Nameplate Capacity Rating & 1,654 & 1,549 & 1,806 & 1,414 & 1,925 & 2,324 & 2,998 & 4,750 \\
\hline Wind Turbine Rotor Diameter & 1,654 & 1,549 & 1,806 & 1,414 & 1,925 & 2,324 & 2,998 & 4,750 \\
\hline Wind Turbine Specific Power & 1,654 & 1,549 & 1,654 & 1,654 & 1,654 & 1,654 & 1,654 & 1,654 \\
\hline Wind Turbine IEC Class & 861 & 803 & 919 & 709 & 865 & 934 & 1,127 & 478 \\
\hline Annual Average Wind Speed & na & na & na & na & na & na & na & na \\
\hline Site Quality & 403 & 338 & 302 & 143 & 123 & na & na & na \\
\hline Full Load Hours (generation in 2012) & 455 & 342 & 312 & 150 & 131 & na & na & na \\
\hline Investment Costs & na & survey based & na & survey based & na & survey based & na & na \\
\hline Operations and Maintenance Costs & na & survey based & na & survey based & na & survey based & na & na \\
\hline Financing Costs & na & na & na & na & na & na & na & na \\
\hline \multicolumn{9}{|l|}{ Sample Size (\%) -- Land-Based, Utility-Scale Only } \\
\hline Wind Project Size & $0 \%$ & $0 \%$ & $0 \%$ & $0 \%$ & $0 \%$ & $0 \%$ & $0 \%$ & $0 \%$ \\
\hline Wind Turbine Nameplate Capacity Rating & $99 \%$ & $94 \%$ & $97 \%$ & $99 \%$ & $99 \%$ & $100 \%$ & $100 \%$ & $100 \%$ \\
\hline Wind Turbine Rotor Diameter & $99 \%$ & $94 \%$ & $97 \%$ & $99 \%$ & $99 \%$ & $100 \%$ & $100 \%$ & $100 \%$ \\
\hline Wind Turbine Hub Height & $99 \%$ & $94 \%$ & $97 \%$ & $98 \%$ & $99 \%$ & $100 \%$ & $100 \%$ & $100 \%$ \\
\hline Wind Turbine Specific Power & $99 \%$ & $100 \%$ & $89 \%$ & $115 \%$ & $85 \%$ & $71 \%$ & $55 \%$ & $35 \%$ \\
\hline Wind Turbine IEC Class & $52 \%$ & $49 \%$ & $50 \%$ & $49 \%$ & $45 \%$ & $40 \%$ & $38 \%$ & $10 \%$ \\
\hline Annual Average Wind Speed & na & na & na & na & na & na & na & na \\
\hline Site Quality & $24 \%$ & $20 \%$ & $16 \%$ & $10 \%$ & $6 \%$ & na & na & na \\
\hline Full Load Hours (generation in 2012/2013) & $27 \%$ & $21 \%$ & $17 \%$ & $10 \%$ & $7 \%$ & na & na & na \\
\hline Investment Costs & na & survey based & na & survey based & na & survey based & na & na \\
\hline Operations and Maintenance Costs & na & survey based & na & survey based & na & survey based & na & na \\
\hline Financing Costs & na & na & na & na & na & na & na & na \\
\hline
\end{tabular}


Table 2-7. Wind Turbine Nameplate Capacity Rating Statistics

Wind Turbine Nameplate Capacity Rating (MW)
\begin{tabular}{|l|r|r|r|r|r|r|r|r|}
\hline & 2007 & 2008 & 2009 & 2010 & 2011 & 2012 & 2013 & 2014 \\
\hline n (\# turbines) & 873.0 & 805.0 & 922.0 & 709.0 & 866.0 & 978.0 & 1154.0 & 1766.0 \\
\hline Median & 2.0 & 2.0 & 2.0 & 2.0 & 2.3 & 2.3 & 2.4 & 2.5 \\
\hline $\begin{array}{l}\text { 25th } \\
\text { percentile }\end{array}$ & 2.0 & 2.0 & 2.0 & 2.0 & 2.0 & 2.0 & 2.3 & 2.3 \\
\hline $\begin{array}{l}\text { 75th } \\
\text { percentile }\end{array}$ & 2.0 & 2.0 & 2.0 & 2.3 & 2.3 & 2.3 & 3.1 & 3.1 \\
\hline Minimum & 0.6 & 0.8 & 0.6 & 0.8 & 0.6 & 0.8 & 0.8 & 0.8 \\
\hline Maximum & 6.0 & 6.0 & 6.0 & 7.6 & 7.6 & 7.6 & 7.6 & 7.6 \\
\hline Average & 1.9 & 1.9 & 2.0 & 2.0 & 2.2 & 2.4 & 2.6 & 2.7 \\
\hline n (MW) & 1653.6 & 1548.7 & 1806.2 & 1413.6 & 1924.7 & 2323.8 & 2998.4 & 4750.3 \\
\hline
\end{tabular}

Salient Notes: All turbines with a known capacity $>=0,5 \mathrm{MW}$, Data from

Betreiberdatenbasis (BDB) and from Deutsche WindGuard Statistics [DWG)

Table 2-8. Wind Turbine Rotor Diameter Statistics

\begin{tabular}{|l|r|r|r|r|r|r|r|r|} 
Wind Turbine Rotor Diameter $(\mathbf{m})$ \\
\hline & 2007 & 2008 & 2009 & 2010 & 2011 & 2012 & 2013 & 2014 \\
\hline $\mathrm{n}$ (\# turbines) & 873.0 & 805.0 & 922.0 & 709.0 & 866.0 & 978.0 & 1154.0 & 1766.0 \\
\hline median & 80.0 & 82.0 & 82.0 & 82.0 & 82.0 & 82.0 & 101.0 & 101.0 \\
\hline 25th percentile & 71.0 & 71.0 & 71.0 & 77.0 & 82.0 & 82.0 & 82.0 & 82.0 \\
\hline 75th percentile & 90.0 & 90.0 & 90.0 & 90.0 & 90.0 & 92.5 & 112.0 & 112.0 \\
\hline minimum & 44.0 & 48.0 & 44.0 & 48.0 & 44.0 & 48.0 & 48.0 & 48.0 \\
\hline maximum & 126.0 & 126.0 & 126.0 & 126.0 & 126.0 & 126.0 & 126.0 & 154.0 \\
\hline average & 77.5 & 79.1 & 78.6 & 79.9 & 83.5 & 87.9 & 94.9 & 99.3 \\
\hline $\mathrm{n}$ (MW) & 1653.6 & 1548.7 & 1806.2 & 1413.6 & 1924.7 & 2323.8 & 2998.4 & 4750.3 \\
\hline
\end{tabular}

Salient Notes: All turbines with a known capacity $>=0,5 \mathrm{MW}$, Data from Betreiberdatenbasis (BDB) and from Deutsche WindGuard Statistics [DWG)

Table 2-9. Wind Turbine Hub Height Statistics

Wind Turbine Hub
Height (m)
\begin{tabular}{|l|r|r|r|r|r|r|r|r|}
\hline & 2007 & 2008 & 2009 & 2010 & 2011 & 2012 & 2013 & 2014 \\
\hline $\mathrm{n}$ (\# turbines) & 873.0 & 805.0 & 922.0 & 707.0 & 866.0 & 978.0 & 1154.0 & 1766.0 \\
\hline median & 98.0 & 100.0 & 100.0 & 105.0 & 105.0 & 108.0 & 125.0 & 123.0 \\
\hline 25th percentile & 74.0 & 76.0 & 73.0 & 78.0 & 85.0 & 98.0 & 99.0 & 94.0 \\
\hline 75th percentile & 105.0 & 105.0 & 108.0 & 108.0 & 128.0 & 138.0 & 138.0 & 139.0 \\
\hline minimum & 49.0 & 50.0 & 50.0 & 50.0 & 56.0 & 58.6 & 50.0 & 50.0 \\
\hline maximum & 138.0 & 141.0 & 141.0 & 140.0 & 141.0 & 145.0 & 149.0 & 149.0 \\
\hline average & 91.0 & 93.6 & 95.3 & 99.0 & 105.7 & 110.8 & 117.0 & 115.6 \\
\hline $\mathrm{n}$ (MW) & 1653.6 & 1548.7 & 1806.2 & 1410.6 & 1924.7 & 2323.8 & 2998.4 & 4750.3 \\
\hline
\end{tabular}

Salient Notes: All turbines with a known capacity $>=0,5 \mathrm{MW}$, Data from

Betreiberdatenbasis (BDB) and from Deutsche WindGuard Statistics [DWG) 
Table 2-10. Wind Turbine Specific Power Statistics

Wind Turbine Specific
Power (W/m ${ }^{2}$ )
\begin{tabular}{|l|r|r|r|r|r|r|r|r|}
\hline & 2007 & 2008 & 2009 & 2010 & 2011 & 2012 & 2013 & 2014 \\
\hline n (\# turbines) & 873.0 & 805.0 & 922.0 & 709.0 & 866.0 & 978.0 & 1154.0 & 1766.0 \\
\hline median & 378.7 & 378.7 & 378.7 & 378.7 & 435.5 & 400.2 & 380.7 & 335.0 \\
\hline 25th percentile & 318.3 & 314.4 & 322.1 & 322.1 & 314.4 & 314.4 & 308.4 & 304.5 \\
\hline 75th percentile & 505.2 & 481.2 & 442.1 & 435.5 & 435.5 & 435.5 & 435.5 & 400.2 \\
\hline minimum & 284.0 & 297.6 & 297.6 & 284.0 & 224.0 & 224.0 & 191.1 & 203.4 \\
\hline maximum & 609.0 & 580.9 & 580.9 & 607.9 & 607.9 & 607.9 & 607.9 & 609.0 \\
\hline average & 404.0 & 396.1 & 406.4 & 393.5 & 410.3 & 394.8 & 376.0 & 361.2 \\
\hline n (MW) & 1653.6 & 1548.7 & 1806.2 & 1413.6 & 1924.7 & 2324.4 & 2998.4 & 4750.3 \\
\hline
\end{tabular}

Salient Notes: All turbines with a known capacity $>=0,5 \mathrm{MW}$, Data from Betreiberdatenbasis and DWG

Table 2-11. Wind Turbine IEC Class Statistics

Wind Turbine IEC Class -
Average Class
\begin{tabular}{|l|r|r|r|r|r|r|r|r|}
\hline & 2007 & 2008 & 2009 & 2010 & 2011 & 2012 & 2013 & 1 st Half 2014 \\
\hline Class I & $8 \%$ & $8 \%$ & $6 \%$ & $7 \%$ & $6 \%$ & $2 \%$ & $3 \%$ & $1 \%$ \\
\hline Class I/II & $37 \%$ & $28 \%$ & $26 \%$ & $17 \%$ & $20 \%$ & $17 \%$ & $17 \%$ & $18 \%$ \\
\hline Class II & $20 \%$ & $23 \%$ & $38 \%$ & $47 \%$ & $45 \%$ & $47 \%$ & $40 \%$ & $46 \%$ \\
\hline Class II/III & $24 \%$ & $33 \%$ & $19 \%$ & $16 \%$ & $23 \%$ & $28 \%$ & $26 \%$ & $29 \%$ \\
\hline Class III & $11 \%$ & $9 \%$ & $11 \%$ & $13 \%$ & $6 \%$ & $5 \%$ & $13 \%$ & $6 \%$ \\
\hline Average & 2.0 & 2.0 & 2.0 & 2.1 & 2.0 & 2.1 & 2.1 & 2.1 \\
\hline n (\# turbines) & 1640 & 1546 & 1804 & 1414 & 1924 & 2237 & 2935 & 1239 \\
\hline n [MW] & 861 & 803 & 919 & 709 & 865 & 934 & 1127 & 478 \\
\hline
\end{tabular}

Salient Notes: All turbines with a known IEC class (i.e., not missing) and capacity >= $1 \mathrm{MW}$, for all projects $>=0.5 \mathrm{MW}$. Turbines rated as spanning two classes are identified as such (e.g., Class II/III) and an "average" class is defined for the purpose of showing trends in the average IEC Class (e.g., a Class II/III machine is given an average class of 2.5) 
Table 2-12. Full Load Hours/Capacity Factors in 2012 Statistics

\begin{tabular}{|c|c|c|c|c|c|c|}
\hline \multicolumn{7}{|c|}{ Full Load Hours in 2012 (equivalent to capacity factor * 8784) } \\
\hline Project COD & 2007 & 2008 & 2009 & 2010 & 2011 & 2012 \\
\hline median & 1,874 & 1,765 & 1,951 & 2,081 & 1,904 & \\
\hline 25th percentile & 1,636 & 1,513 & 1,711 & 1,853 & 1,669 & \\
\hline 75th percentile & 2,224 & 2,105 & 2,171 & 2,399 & 2.135 & \\
\hline minimum & 1,171 & 988 & 1,043 & 1,423 & 1,159 & \\
\hline maximum & 3,724 & 2,812 & 3,497 & 3,132 & 3,030 & \\
\hline generation-weighted average & 1,991 & 1,857 & 2,019 & 2,133 & 1,955 & \\
\hline $\mathrm{n}$ [\# of turbines] & 225 & 174 & 162 & 77 & 61 & \\
\hline $\mathrm{n}[\mathrm{MW}]$ & 455 & 342 & 312 & 150 & 131 & \\
\hline
\end{tabular}

\begin{tabular}{|c|c|c|c|c|c|c|}
\hline \multicolumn{7}{|c|}{ Capacity Factor in 2012 (equivalent to full load hours divided by 8784) } \\
\hline & 2007 & 2008 & 2009 & 2010 & 2011 & 2012 \\
\hline median & $21.3 \%$ & $20.1 \%$ & $22.2 \%$ & $23.7 \%$ & $21.7 \%$ & $0.0 \%$ \\
\hline 25th percentile & $18.6 \%$ & $17.2 \%$ & $19.5 \%$ & $21.1 \%$ & $19.0 \%$ & $0.0 \%$ \\
\hline 75th percentile & $25.3 \%$ & $24.0 \%$ & $24.7 \%$ & $27.3 \%$ & $24.3 \%$ & $0.0 \%$ \\
\hline minimum & $13.3 \%$ & $11.2 \%$ & $11.9 \%$ & $16.2 \%$ & $13.2 \%$ & $0.0 \%$ \\
\hline maximum & $42.4 \%$ & $32.0 \%$ & $39.8 \%$ & $35.7 \%$ & $34.5 \%$ & $0.0 \%$ \\
\hline generation-weighted average & $22.7 \%$ & $21.1 \%$ & $23.0 \%$ & $24.3 \%$ & $22.3 \%$ & $0.0 \%$ \\
\hline
\end{tabular}

Table 2-13. Site Quality Statistics

\begin{tabular}{|l|r|r|r|r|r|}
\hline Site Quality & & & & & \\
\hline & 2007 & 2008 & 2009 & 2010 & 2011 \\
\hline $\mathrm{n}$ (\# turbines) & 205 & 172 & 159 & 74 & 58 \\
\hline median & $69 \%$ & $67 \%$ & $66 \%$ & $76 \%$ & $72 \%$ \\
\hline 25th percentile & $62 \%$ & $58 \%$ & $60 \%$ & $65 \%$ & $61 \%$ \\
\hline 75 th percentile & $76 \%$ & $77 \%$ & $79 \%$ & $81 \%$ & $87 \%$ \\
\hline minimum & $43 \%$ & $36 \%$ & $42 \%$ & $50 \%$ & $48 \%$ \\
\hline maximum & $133 \%$ & $126 \%$ & $107 \%$ & $101 \%$ & $122 \%$ \\
\hline generation-weighted & $76 \%$ & $73 \%$ & $73 \%$ & $75 \%$ & $80 \%$ \\
\hline caverage & $72 \%$ & $70 \%$ & $71 \%$ & $73 \%$ & $77 \%$ \\
\hline average & $72 \%$ & $69 \%$ & $70 \%$ & $73 \%$ & $75 \%$ \\
\hline n (MW) & 403 & 338 & 302 & 143 & 123 \\
\hline
\end{tabular}


Table 2-14. Investment Costs Statistics

Wind Project Investment Costs (2012 EUR per kW)
\begin{tabular}{|l|r|r|r|}
\hline & 2008 & 2010 & 2012 \\
\hline capacity-weighted average & $1,477 €$ & $1,450 €$ & $1,564 €$ \\
\hline$<2 \mathrm{MW}$ und $<100 \mathrm{~m}$ hub height & $1,427 €$ & $1,546 €$ & $1,461 €$ \\
\hline$<2 \mathrm{MW}$ und 100 bis $<120 \mathrm{MW}$ hub height & $1,540 €$ & & $1,574 €$ \\
\hline $2-3 \mathrm{MW}$ and $<100 \mathrm{~m}$ hub height & $1,373 €$ & $1,333 €$ & $1,395 €$ \\
\hline $2-3 \mathrm{MW}$ and 100 bis $<120 \mathrm{~m}$ hub height & $1,581 €$ & $1,510 €$ & $1,520 €$ \\
\hline $2-3 \mathrm{MW}$ and $>=120 \mathrm{~m}$ hub height & & & $1,743 €$ \\
\hline
\end{tabular}

\section{Wind Project Investment Costs (2012 USD per kW)}

\begin{tabular}{|l|rr|rr|rr|}
\hline & & 2008 & & 2010 & 2012 \\
\hline capacity-weighted average & $\$$ & 1,898 & $\$$ & 1,863 & $\$$ & 2,010 \\
\hline$<2 \mathrm{MW}$ und $<100 \mathrm{~m}$ hub height & $\$$ & 1,833 & $\$$ & 1,987 & $\$$ & 1,877 \\
\hline$<2 \mathrm{MW}$ und 100 bis $<120 \mathrm{MW}$ hub height & $\$$ & 1,979 & $\$$ & - & $\$$ & 2,022 \\
\hline $2-3 \mathrm{MW}$ and $<100 \mathrm{~m}$ hub height & $\$$ & 1,764 & $\$$ & 1,713 & $\$$ & 1,792 \\
\hline $2-3 \mathrm{MW}$ and 100 bis $<120 \mathrm{~m}$ hub height & $\$$ & 2,032 & $\$$ & 1,940 & $\$$ & 1,954 \\
\hline $2-3 \mathrm{MW}$ and $>=120 \mathrm{~m}$ hub height & $\$$ & - & $\$$ & - & $\$$ & 2,239 \\
\hline
\end{tabular}

Table 2-15. O\&M Costs Statistics

\begin{tabular}{|c|c|c|c|c|c|c|}
\hline \multicolumn{7}{|c|}{ Operation and Maintenance Costs (2012 EUR per kW-year) } \\
\hline & 2007 & 2008 & 2009 & 2010 & 2011 & 2012 \\
\hline First Decade & & 51 & & 48 & & 53 \\
\hline Second Decade & & 64 & & 66 & & 59 \\
\hline Average & & 58 & & 57 & & 56 \\
\hline
\end{tabular}

Operation and Maintenance Costs (2012 USD per kW-year)
\begin{tabular}{|l|r|r|r|r|r|r|}
\hline & 2007 & 2008 & 2009 & 2010 & 2011 & 2012 \\
\hline First Decade & & 66 & & 66 & & 68 \\
\hline Second Decade & & 82 & & 82 & & 76 \\
\hline Average & & 74 & & 73 & & 72 \\
\hline
\end{tabular}




\section{Chapter 3. Wind Energy Development in Ireland}

Authors: Aidan Duffy (Dublin Institute of Technology and Dublin Energy Lab), Brendan Cleary (Dublin Institute of Technology and Dublin Energy Lab)

This chapter should be cited as: Duffy, A., Cleary, B. (2015). "Wind Energy Development in the Ireland," Chapter 3. Hand, M. M., ed., IEA Wind Task 26 - Wind Technology, Cost, and Performance Trends in Denmark, Germany, Ireland, Norway, the European Union, and the United States: 2007-2012. NREL/TP-6A20-64332. Golden, CO: National Renewable Energy Laboratory. pp. 75-100.

\section{Domestic Wind Energy Capacity, Production, and Targets}

The European Union Renewable Energy Directive 2009/28/EC sets a target for the Republic of Ireland to meet $16 \%$ of gross final consumption from renewable energy sources by 2020 , with separate targets for contributions of renewable energy in electricity $(40 \%)$, transport $(10 \%)$, and heat (12\%) [1], [2].The majority of the electricity target (circa 37\%) will be met from land-based wind energy, given the significant wind resource which exists in the Republic of Ireland and the maturity of the technology nationally. The Republic of Ireland is, on average, half way towards meeting its 2020 targets, $21 \%$ of electricity, $4.9 \%$ of transport, and $5.7 \%$ of heat is now produced from renewable sources [3]. In 2013, the Republic of Ireland produced approximately $18 \%$ of its electricity demand from wind, with an installed capacity of 1,999 MW [3]. A total installed landbased wind capacity of 3,575 MW is planned for 2020 to meet policy targets, requiring the addition of 1,601 MW in the period 2014-2020 (see Figure 3-1 and Table 3-1) [4].

Annual wind capacity additions for each year since 2000 are shown in Table 3-2. The installed wind capacity increased by almost four-fold between 2000 and 2005, from $114 \mathrm{MW}$ to $506 \mathrm{MW}$. This included the first offshore wind plant with an installed capacity of 25 MW in 2003. However, the rate of capacity growth fluctuated throughout the period 2000-2014 for a variety of policy and market reasons. Between 2006 and 2014, national wind capacity expanded by almost three-fold from $688 \mathrm{MW}$ to $2,165 \mathrm{MW}$, representing an average growth rate of 185 MW/year. Capacity expansion in the period 2006-2010 was driven by a 2010 policy target of $1,350 \mathrm{MW}$. By 2007, additional generation capacity of only $64 \mathrm{MW}$ of had been built, but 2008 and 2009 saw significantly greater commissioning rates of over $200 \mathrm{MW}$ and $300 \mathrm{MW}$, respectively. Given the high wind penetration targets and the relatively isolated nature of the Irish grid, uncertainty about the level and market treatment of curtailment became a significant barrier to investment after 2010. This led to a drop-off in investment in 2012 in particular; while the proposed arrangements for treatment of wind curtailment were being finalized. Total installed wind capacity in Ireland at the end of 2014 was 2,165 MW (2,140 MW land-based and $25 \mathrm{MW}$ offshore). 


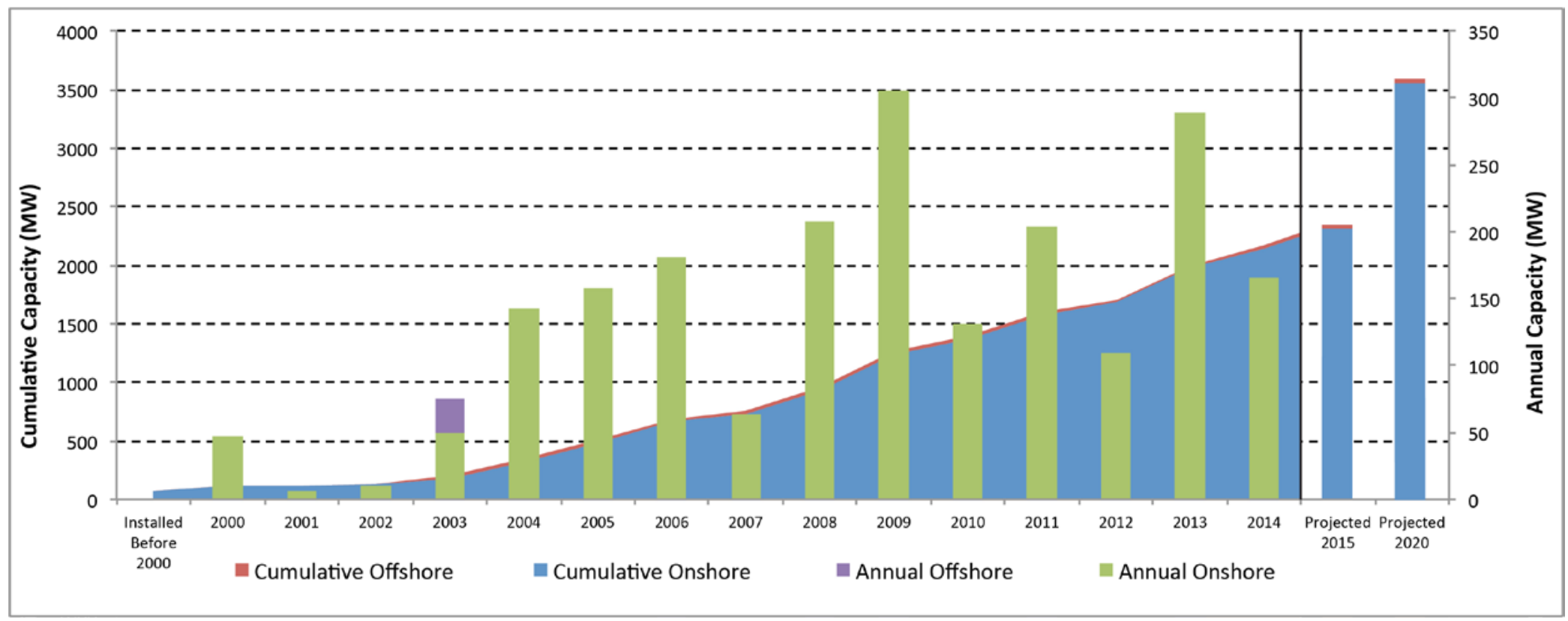

Figure 3-1. Cumulative and annual wind installations in the Republic of Ireland

Table 3-1. Cumulative and Annual Capacity (MW) Installed in the Republic of Ireland

\begin{tabular}{|c|c|c|c|c|c|c|c|c|c|c|c|c|c|c|c|c|c|c|}
\hline \multicolumn{17}{|c|}{ Wind Project Capacity and Targets (MW) } & \multicolumn{2}{|c|}{ PROJECTIONS } \\
\hline & & $<2000$ & 2000 & 2001 & 2002 & 2003 & 2004 & 2005 & 2006 & 2007 & 2008 & 2009 & 2010 & 2011 & 2012 & 2013 & 2015 & 2020 \\
\hline Cumulative & Onshore & 67 & 114 & 120 & 130 & 181 & 323 & 481 & 663 & 727 & 934 & 1,240 & 1,371 & 1,575 & 1,685 & 1,974 & 2,665 & 3,475 \\
\hline Cumulative & Offshore & 0 & 0 & 0 & 0 & 25 & 25 & 25 & 25 & 25 & 25 & 25 & 25 & 25 & 25 & 25 & 25 & 25 \\
\hline Annual & Onshore & & 47 & 6 & 10 & 50 & 143 & 158 & 181 & 64 & 207 & 306 & 132 & 203 & 110 & 289 & 346 & 162 \\
\hline Annual & Offshore & & 0 & 0 & 0 & 25 & 0 & 0 & 0 & 0 & 0 & 0 & 0 & 0 & 0 & 0 & 0 & 0 \\
\hline
\end{tabular}




\section{Revenue and Policy Incentives}

A variety of incentives have been used in the wind industry over the last 25 years. However, the current Renewable Energy Feed in Tariff (REFIT) has been in place for eight years and has thus provided a relatively stable investment environment.

From the late 1980s, an obligation was placed upon the then state electricity monopoly, the Electricity Supply Board (ESB), to purchase renewable electricity, which effectively amounted to a government-sponsored feed-in tariff. In 1995, the first government price support scheme for renewable electricity was introduced, replacing the earlier scheme. This auction scheme, known as the Alternative Energy Requirement (AER), or AER I, was a competitive tendering process used to allocate 15-year, fixed-price power purchase agreements (PPAs) [5]. A total of four AER programs aimed at wind energy were run between 1996 and 2004. In 1996, AER I authorized contracts for wind generation capacity totaling $30 \mathrm{MW}$. AER III in 1999 authorized contracts totaling $90 \mathrm{MW}$ for wind power projects and, in February 2002, AER V was announced, authorizing a total of $353 \mathrm{MW}$ of generating capacity from wind power. The results of the last round, AER VI, in which contracts for $334 \mathrm{MW}$ of wind projects were awarded, were announced in July 2003. Support for an additional 235 MW of wind projects under AER VI was announced in December 2004, after EU state aid approval for support for this additional capacity was received. The last round of competitive tendering under the AER took place in 2005. In total AER contracts for 1,042 MW of land-based wind capacity were allocated but only $532 \mathrm{MW}$ were constructed [6]. The scheme therefore failed to achieve the anticipated policy targets, and it was replaced with the REFIT scheme in 2006, which is still in place today.

The REFIT scheme was delivered in two phases [7]. REFIT 1 contracts were awarded between 2006 and 2010, and qualifying projects can be executed up to the end of 2015. The replacement REFIT 2 scheme was opened for applications in March 2012 and has a deadline of the end of 2017 for the energizing of qualifying projects. The payments defined under REFIT 1 and REFIT 2 are identical, but the arrangements for market compensation accruing to PPA counterparties are modified under REFIT 2. The REFIT scheme for wind is funded through a European Commission (EC) state-aid sanctioned, Public Service Obligation (PSO) levy on all electricity consumers. The total PSO amount levied in $2012 / 2013$ was $€ 131$ million; peat generation, provision for security of supply generation, and renewable electricity generation accounted for $39 \%, 19 \%$, and $42 \%$ of the PSO, respectively [8].

The REFIT payments consist of three parts. The first part is independent of the market price of electricity obtained in the mandatory Single Electricity Market (SEM) pool and entitles suppliers to a Balancing Payment (BP) to cover the notional cost of managing the short term variability of wind generation in the SEM [10]. Under REFIT 1, the supplier is automatically entitled to a balancing payment equivalent to $15 \%$ of the REFIT 1 reference price for every MWh purchased from the wind generator under the PPA. Under REFIT 2, the balancing payment has been fixed at $€ 9.90 / \mathrm{MWh}$ and is not subject to inflation. The second part is a REFIT reference price which was equal to $€ 69.24 / \mathrm{MWh}$ and $€ 71.66 / \mathrm{MWh}$ for wind projects greater and less than $5 \mathrm{MW}$ in 2013, respectively [7]. The third part is the technology difference payment, which is paid in addition to the reference price for all renewables other than large scale wind, to compensate suppliers for the higher costs of generation from other technologies. Large scale wind refers to any wind project with an installed capacity greater than $5 \mathrm{MW}$. 
The REFIT paid to a supplier who has entered into a PPA $i$ with a generator using technology $r$ can be defined as [6]:

$$
\operatorname{REFIT}_{i}^{r}=\left(B P+T D^{r}+M E\right) n_{i}^{r}
$$

where:

$\mathrm{BP}, \mathrm{ME}$ and TD are described in equations (2)-(5) below;

$n_{i}^{r}$ is the amount of electricity produced under the PPA $i$ in a given year;

$r$ is the index of the technology type.

The BP for REFIT 2 is fixed at $€ 9.90 / \mathrm{MWh}$ while for REFIT 1 it is defined as:

$$
B P=\left(0.15 x P^{R E F T T_{1}}\right)
$$

The Market Equalisation (ME) payment is defined as:

$$
M E= \begin{cases}\left(P^{R E F I T_{j}}-\bar{W}\right) & \text { if } \ldots P^{R E F I T_{j}}>\bar{W} \\ 0 & \text {...otherwise }\end{cases}
$$

If the average wholesale SEM price $\bar{W}$ is less than the REFIT reference price $P^{R E F I T_{j}}$ (where $j$ indexes either REFIT 1 or 2), the supplier receives the difference between the two prices [6]. Wind projects enter into a 15-year PPA with electricity suppliers at a negotiated price per unit of electricity. The supplier then sells the electricity into the SEM pool. If the SEM price a supplier receives for each half-hourly trading period during the year is less than the $P^{R E F I T_{j}}$, then the difference is paid through the PSO mechanism. When the SEM price a supplier receives for each trading period during the year is higher than the $P^{R E F I T_{j}}$, those generators in the AER scheme pay back the additional market revenue to the PSO fund, while generators in the REFIT scheme retain the market revenue [9].

The technology difference payment $T D^{r}$ depends on the REFIT phase. Under REFIT 1, equation (4) indicates that the technologies depend on $P^{P P A}$, the price per MWh specified in the PPA between the generator and supplier; $G^{r}$ the relevant technology reference price for each generation type $r$; and the appropriate REFIT reference price $P^{R E F I T_{j}}[6]$.

$$
T D^{r}= \begin{cases}\left(G^{r}-P^{R E F T T_{1}}\right) & \text { if } \ldots P^{P P A} \geq G^{r} \\ \left(P^{P P A}-P^{R E F I T_{1}}\right) & \text { if } \ldots P^{R E F I T_{1}} \leq P^{P P A}<G^{r} \\ 0 & \text { if } \ldots P^{P P A}<P^{R E F I T 1}\end{cases}
$$

For technologies that fall under REFIT 2, the technology payment depends on the average wholesale SEM price $\bar{W}, P^{P P A}$ and $G^{r}$ as shown in equation (5). In practice it is unlikely that $P^{P P A}$ would be lower than $G^{r}[6]$.

$$
T D^{r}= \begin{cases}\left(G^{r}-\bar{W}\right) & \text { if } \ldots P^{P P A} \geq G^{r} \geq \bar{W} \\ \left(P^{P P A}-\bar{W}\right) & \text { if } \ldots \bar{W} \leq P^{P P A}<G^{r} \\ 0 & \text { if } \ldots P^{P P A}<\bar{W}\end{cases}
$$


Tax incentive schemes for renewable energy investments are available under Section $486 \mathrm{~b}$ of the 1998 Finance Act and, in particular, on capital directly invested in wind plant assets. Corporate investors in renewable energy projects can claim tax relief on equity investment in capital assets. The corporate tax rate has been reduced to $12.5 \%$ since 1998 .

Other tax-based support measures include the Employment and Investment Incentive (EII) scheme, which allows individual investors to obtain income tax relief on investments in wind energy in each tax year [11]. This scheme supersedes the previous Business Expansion Scheme (BES). It provides a minimum tax relief of $30 \%$ with an additional $11 \%$ accruing at the end of the third and final year if the business has expanded to employ a designated number of people (or if the investment was used for R\&D). The scheme has an investment cap of $€ 2$ million subject to a maximum of $€ 1.5$ million in any one twelve month period and is thus of limited value to larger wind energy projects [11]. A number of financial services companies offer EII Funds or portfolios to investors.

In 2008, the Irish Government introduced an Accelerated Capital Allowance (ACA) scheme for companies investing in energy efficient technologies [12]. Under this scheme, companies investing in qualifying wind turbines can fully depreciate their investment for tax purposes in the first year, rather than over a more prolonged period, thus aiding their cash flow.

The 1999 Irish Government Green Paper on Sustainable Energy set out a program of Sustainable Energy Research, Demonstration \& Development (R, D\& D) with a budget of $€ 50$ million for the years 2000-2006. The Sustainable Energy Authority of Ireland (SEAI) was charged with administering this budget and, in August 2002, SEAI launched the Renewable Energy R, D\& D program [13]. Funding of the program was renewed in the National Development Plan 20072013 under the Government's Strategy for Science, Technology and Innovation (2006-2013).

The focus of the program is to stimulate the application and further deployment of renewable energy, particularly those technologies closest to market viability. The primary program objectives are to remove barriers to the deployment of renewable energy technologies and help stimulate the development of an Irish renewable energy industry. The program strategy was reviewed to align it with the priorities in the 2008 white paper 'Delivering a Sustainable Energy Future for Ireland' [14]. In the period from 2003 to 2013, the program allocated grants for wind energy R\&D in excess of $€ 2.5$ million.

\section{Wind Energy Project Trends in Ireland since 2007}

This section summarizes the technical and financial trends in the Irish wind industry since 2007. SEAI's wind plant database, containing installed capacity and year of connection for individual wind plants, was used as a starting point to create a detailed database of installed wind energy projects in Ireland between 2007 and 2012. Additional technical data were obtained from the Irish Wind Energy Association (IWEA), including wind turbine make and model [15]. Performance data, such as full-load hours and capacity factors, were calculated based on aggregated county-level wind production output data provided by the transmission system operator Eirgrid [16]. The investment costs and operation and maintenance costs were extracted from financial reports filed by wind project owners with the Irish Companies Registration Office [17]. Financing costs were obtained from literature and verified with major Irish lending 
institutions [18]. The sample size for the technical and financial data for each year is contained in the Appendix 3-A.

\section{Project Features}

Onshore wind energy projects in Ireland are generally in the form of clusters ranging from 2 to 19 wind turbines. Land zoning and the highly dispersed nature of rural settlement limits the area of land that can be used for individual wind project development in Ireland. The development and ownership of wind projects in Ireland is characterized by a variety of technology types and scales of investment. Approximately 50\% of wind projects are owned and operated by vertically integrated energy utilities, while the balance is a mix of small, privately-owned wind plant operators, individual landowners, and community groups.

Since 2007, the average wind project size in Ireland has remained between $10 \mathrm{MW}$ and $17 \mathrm{MW}$ as shown in Figure 3-2.. A box and whiskers format is used to represent the projects or turbines that achieved commercial operation in a given year including the median (horizontal line), average (diamond), 25th to 75th percentile (box), and minimum and maximum (whiskers). The largest wind plants of between $40 \mathrm{MW}$ and $60 \mathrm{MW}$ were installed between 2008 and 2011. The largest wind project size is $57 \mathrm{MW}$ with 19 wind turbines. The average wind project size was larger in 2008 and 2009 with $17 \mathrm{MW}$ and $15 \mathrm{MW}$, respectively. In 2011, average wind project size returned to 2007 levels.

The increasing trend of wind turbine capacity rating for each year since 2007 is shown in Figure 3-3. The average wind turbine capacity rating increased almost two-fold from $1.2 \mathrm{MW}$ to 2.3 MW between 2007 and 2012. The maximum rated turbine capacity was $3 \mathrm{MW}$, which occurred in 2009 and 2012. As the development of more advanced wind turbine components has

progressed and, in turn, larger turbines have evolved, wind projects in Ireland have progressively used larger wind turbines. Moreover, empirical evidence from the Irish wind energy industry suggests that larger wind turbines have been used in recent years in order to ensure the available low wind resource locations were financially viable.

The trend since 2007 of increasing wind turbine rotor diameter (shown in Figure 3-4) coincided with the increase in wind turbine capacity referred to above. Generally, as wind turbines became larger, so did their dimensions, such as the rotor diameter. Between 2007 and 2012, the average wind turbine rotor diameter increased from $57 \mathrm{~m}$ to $78 \mathrm{~m}$. In particular, between 2011 and 2012, the use of larger rotor diameters was noticeable with a maximum of $100 \mathrm{~m}$ in 2011 . This increasing trend was reflective of the emergence of larger wind turbines and wind projects in Ireland being sited in locations with lower wind speeds. 


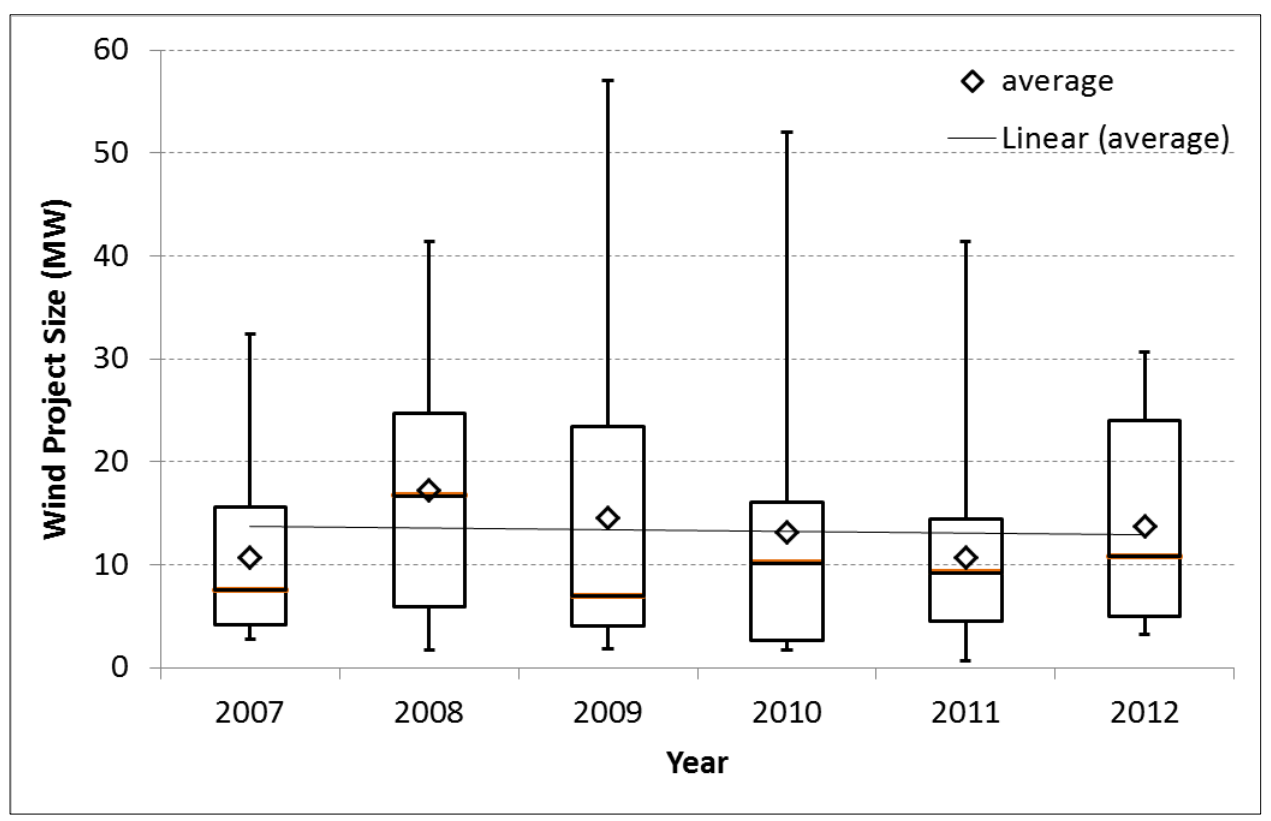

Figure 3-2. Wind project size trends from 2007 to 2012

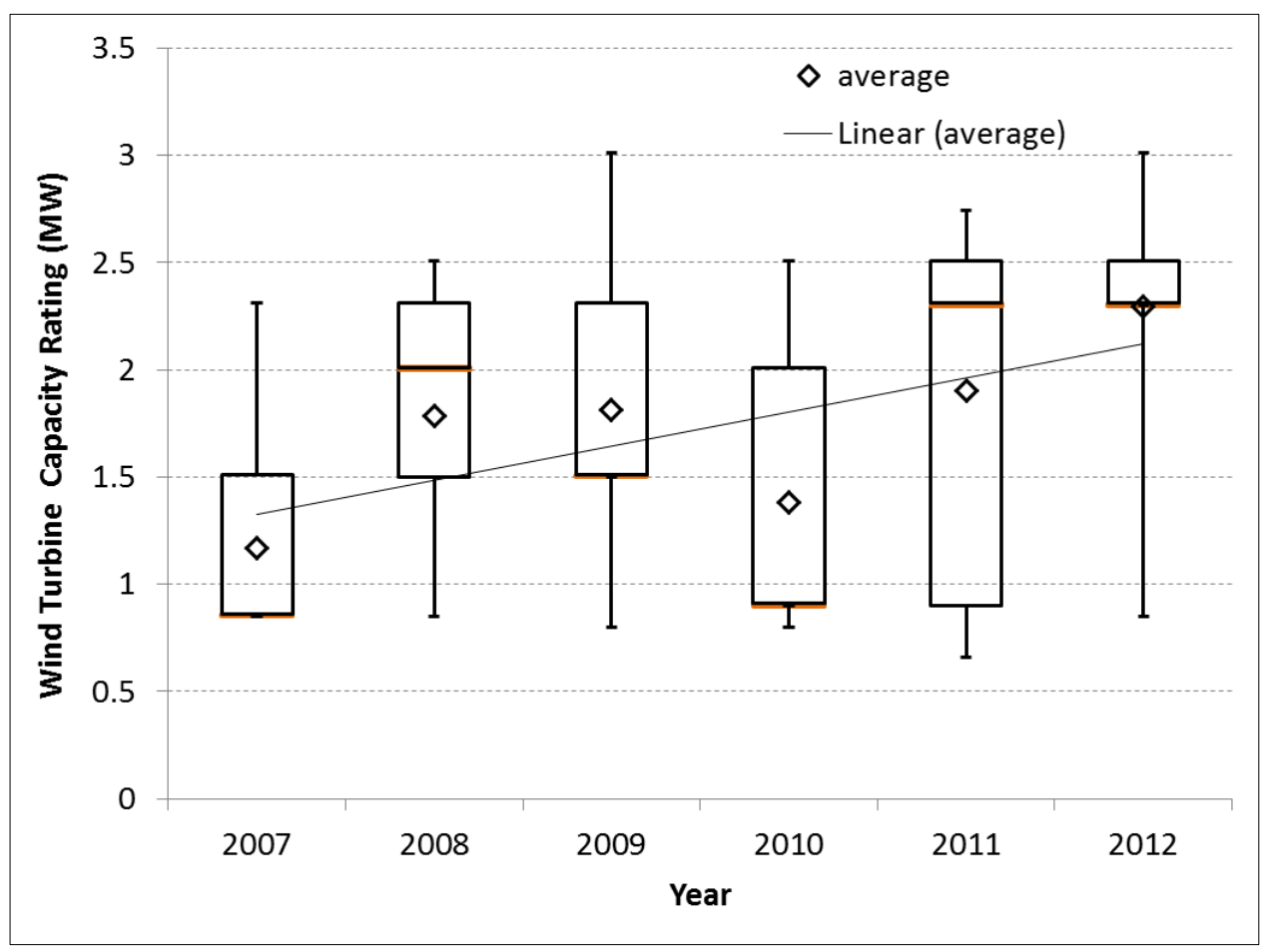

Figure 3-3. Wind turbine nameplate capacity trends from 2007 to 2012 


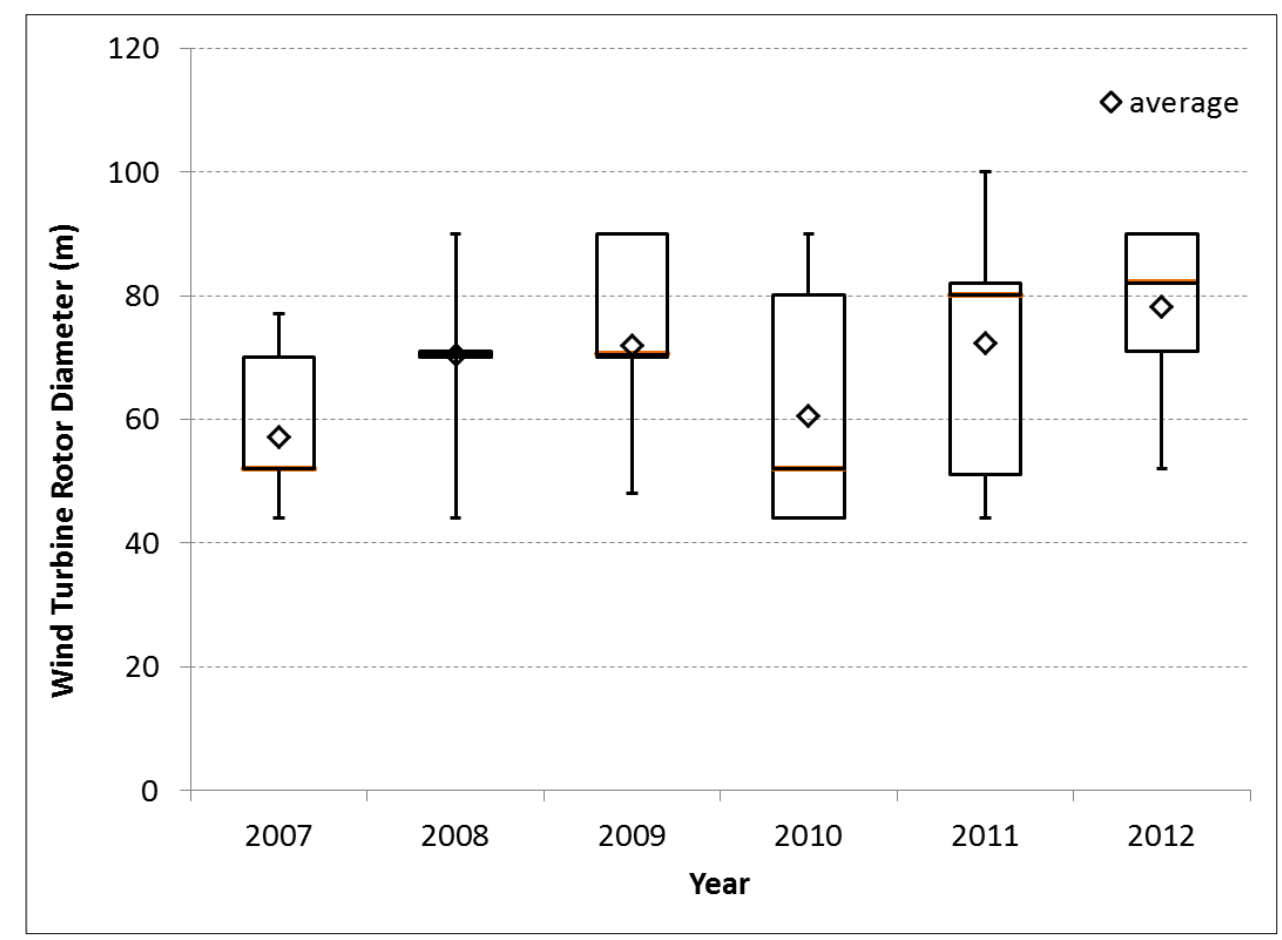

Figure 3-4. Wind turbine rotor diameter trends from 2007 to 2012

The average turbine specific power in Ireland has remained between $400 \mathrm{~W} / \mathrm{m}^{2}$ and $480 \mathrm{~W} / \mathrm{m}^{2}$ as shown in Figure 3-5. The turbine specific power is defined as the turbine nameplate capacity rating divided by the rotor swept area $\left(\mathrm{W} / \mathrm{m}^{2}\right)$. In general, low specific-power turbines were historically designed for lower wind speed sites, but these turbines have increasingly been used for a wide range of wind resource conditions. The increasing rotor diameter coincided with the increase in turbine capacity, and this is reflected by the stable average turbine specific power values shown in Figure 3-5. However, in 2012, there was an increase in specific power which indicates the turbine capacity increased at a relatively greater rate than the rotor diameter.

Average wind turbine hub height increased from $50 \mathrm{~m}$ in 2007 to $73 \mathrm{~m}$ in 2012 as shown in Figure 3-6. Again, this trend can be attributed to wind projects being sited in lower wind resource locations than previous years, thus requiring higher hub heights to capture greater wind speeds. 


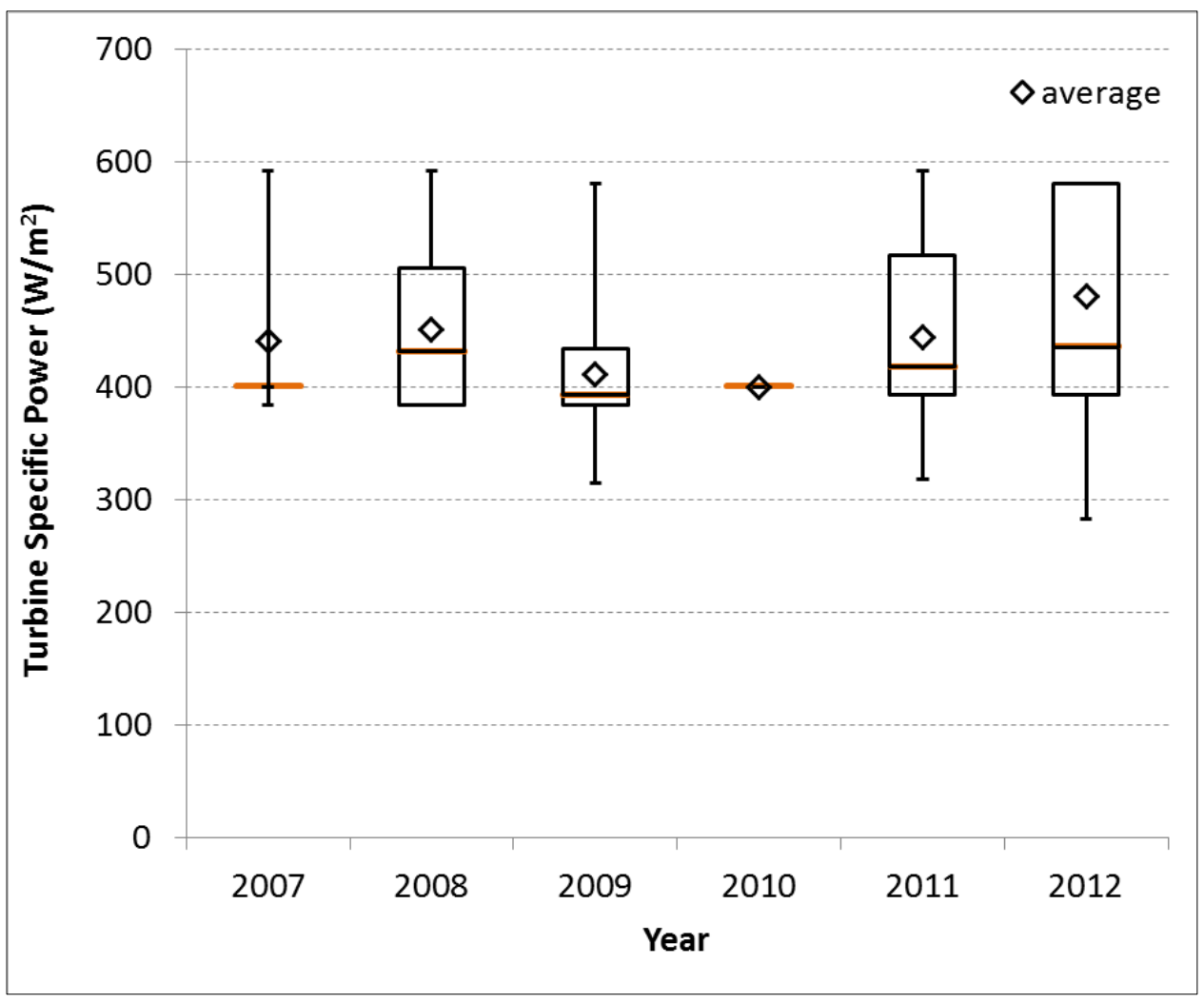

Figure 3-5. Wind turbine specific power trends from 2007 to 2012

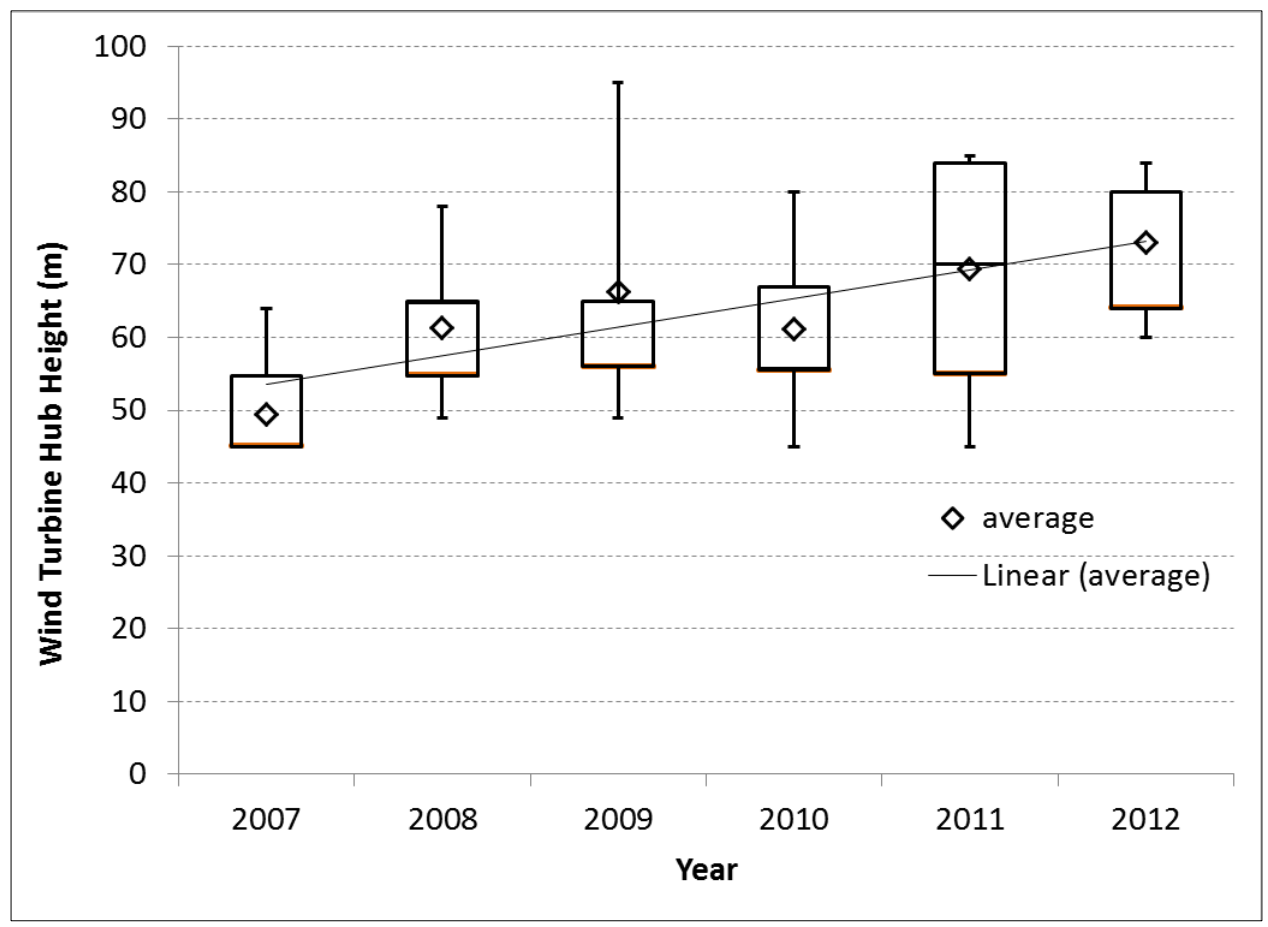

Figure 3-6. Wind turbine hub height trends from 2007 to 2012 
The International Electro-Technical Commission (IEC) classes of wind turbines installed between 2007 and 2012 are shown in Figure 3-7. The IEC classification for a wind turbine is specified, in part, by the annual average wind speed for the turbine design. In general, Class I turbines are designed for higher annual average wind speeds than Class III turbines. Moreover, Class I turbines tend to have higher specific power than Class III turbines. The predominant IEC classes used between 2007 and 2012 are Class I and II turbines given the significant wind resource that exists in Ireland. The only use of Class III turbines is in 2009, although it expected that the use of this turbine class will increase in the coming years as projects are developed in the remaining lower wind resource locations.

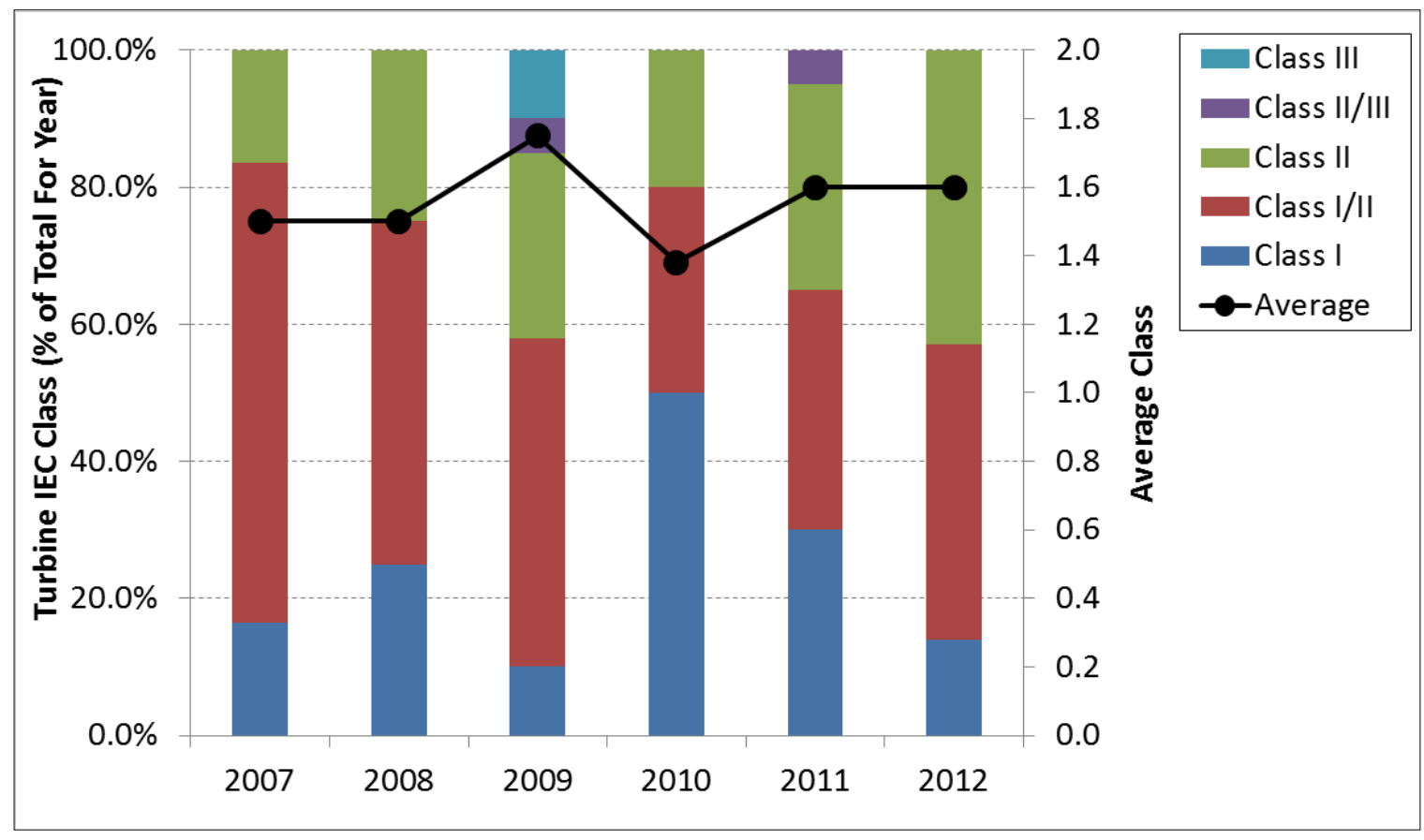

Figure 3-7. Proportion of turbines by IEC class installed from 2007 to 2012

\section{Project Performance}

The wind resource in Ireland is considered to be one of the best in the world making it a key location for wind project investment and development. The prevailing wind direction is between south and west, which makes locations along the west coast of Ireland the most feasible for wind projects. Wind resource generally declines eastwards with west coast sites typically having an average annual wind speed of $9 \mathrm{~m} / \mathrm{s}$ at $75 \mathrm{~m}$ compared to $7 \mathrm{~m} / \mathrm{s}$ at the same elevation in the east coast [19]. Figure 3-8 shows the annual average wind speed for installed wind projects declined from $8.4 \mathrm{~m} / \mathrm{s}$ (at $75 \mathrm{~m}$ elevation) in 2007 to $8.0 \mathrm{~m} / \mathrm{s}$ in 2012, with the greatest decline occurring in 2011-2012. 


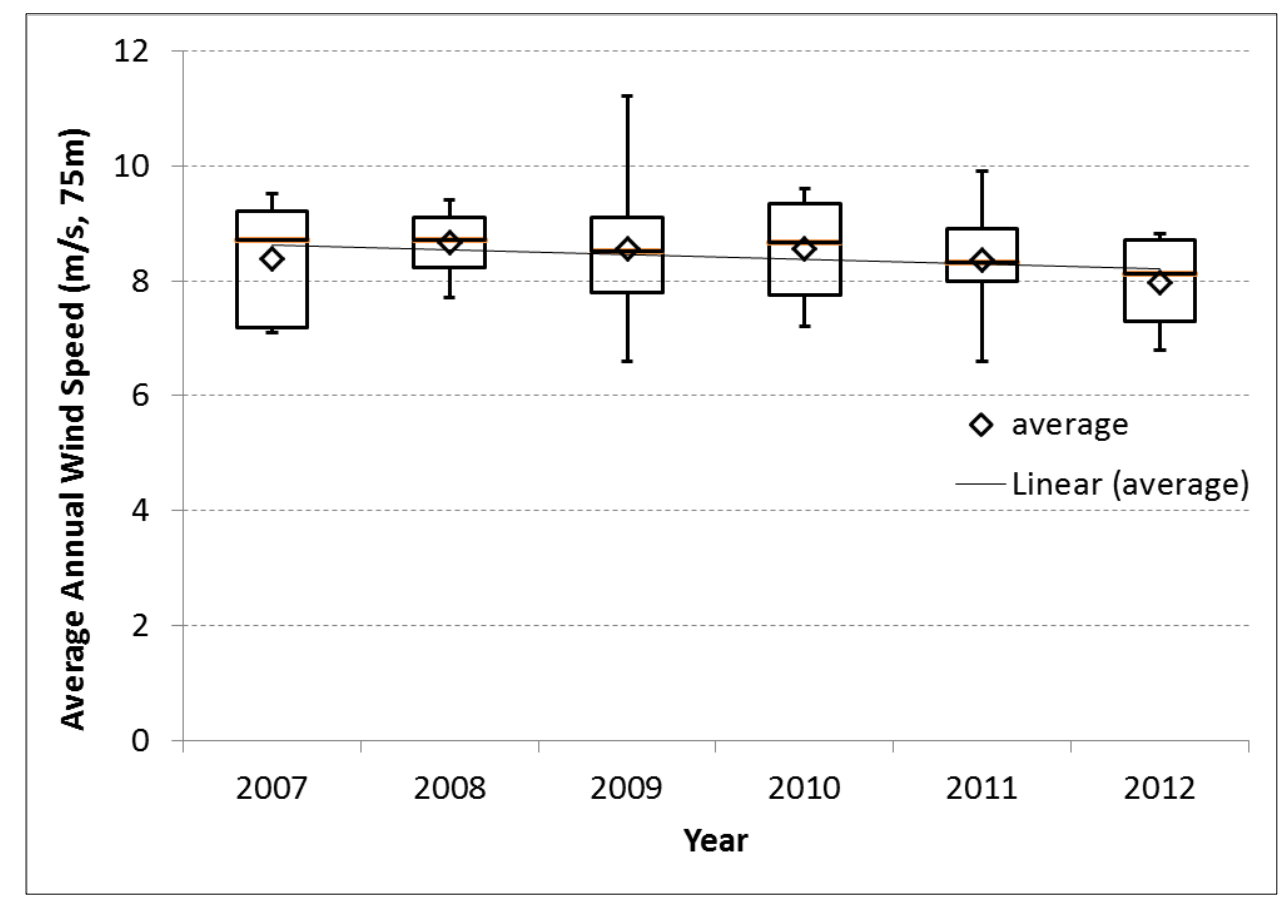

Figure 3-8. Annual average wind speed for projects installed from 2007 to 2012, operating in 2013

The full-load hours and capacity factors for wind projects installed from 2007 to 2012 are shown in Figure 3-9. These are based on the performances in 2013 of all projects built in each of the years 2007-2012. The 2013 wind production output data were corrected using a production index which normalized 2013 output to take account of the wind resource and wind project outage characteristics for that year. Further information on the production index methodology is contained in the Appendix 3-A.

The generation-weighted average full-load hours varied from 2,250 to 3,000 hours for projects installed in each of the years 2007 to 2012 as shown in Figure 3-9. There is a general decrease in full-load hours with project age, with the oldest projects (2007) recording the average lowest full-load hours of 2,250. The highest generation-weighted average capacity factors of approximately 35\% occurred for wind projects installed in 2009, 2011, and 2012. The greatest ranges of capacity factors (approximately 6\% to 45\%) are observed for plants built in 2009 and 2011. The low capacity factors $(6 \%)$ can be attributed to single wind turbine and/or small wind projects which are generally auto-producers, for which full production output data was not available. It is interesting to note that although wind projects are increasingly using lower wind resource locations (see Figure 3-8), average capacity factors for projects built in 2011 and 2012 remained high. This would suggest that the larger wind turbines with increased rotor diameters and hub heights are successful in achieving a viable energy yield from these locations. 


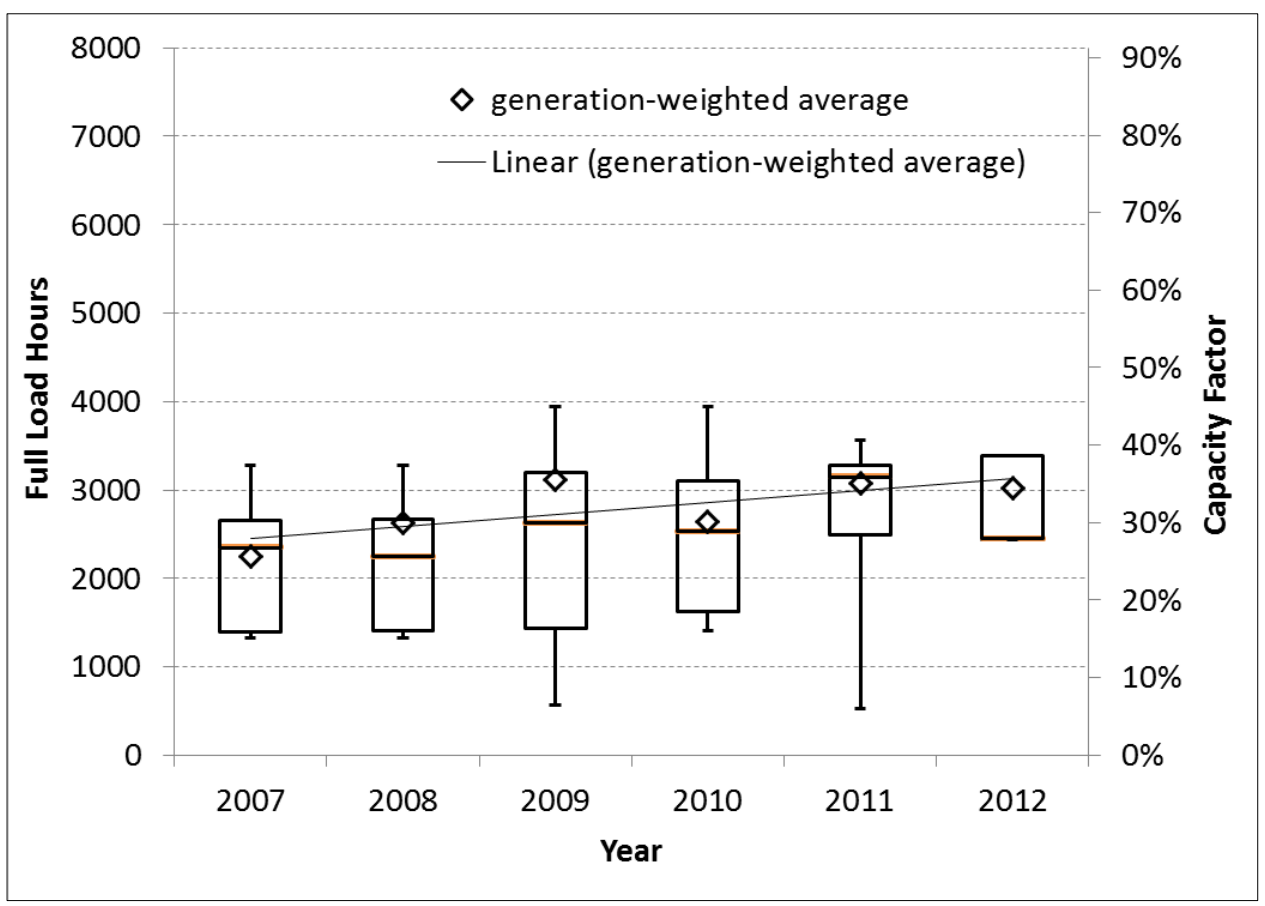

Figure 3-9. Full-load hours for projects installed from 2007 to 2012, operating in 2013

\section{Investment Costs}

The capacity-weighted average investments costs of Irish wind projects ranged from $€ 990 / \mathrm{kW}$ to $€ 1,658 / \mathrm{kW}$ (2012 prices) between 2007 and 2012 as shown in Figure 3-10. Overall the cost trend was upwards over the period, although in 2011 average costs fell. Empirical evidence from the Irish wind energy industry suggests that wind turbine and civil works costs may be declining, resulting in an overall decrease in investment costs. However, this is not clearly reflected in the data obtained in this study. There is no single obvious explanation for the observed upward cost trend. This may be due to a variety of factors such as: tight construction market conditions (particularly 2007/8 feeding into 2009); high international demand for wind turbines; increased rotor diameters and associated increased turbine costs; and other cost components such as higher grid integration costs.

A recent report by Fitzgerald et al. [20] provides a breakdown of investment costs based on survey responses from the Irish wind energy industry; this is shown in Figure 3-11. While it indicates grid/network development accounts for $9 \%$ of investment costs, this analysis found grid connection costs have increased two-fold in the period 2007-2012 and can contribute up to 23\% of investment costs. However, these costs are project-specific and depend on the wind project's vicinity to the grid infrastructure. Also, it did not prove possible to obtain a breakdown of the remaining individual cost components of wind projects investment costs. 


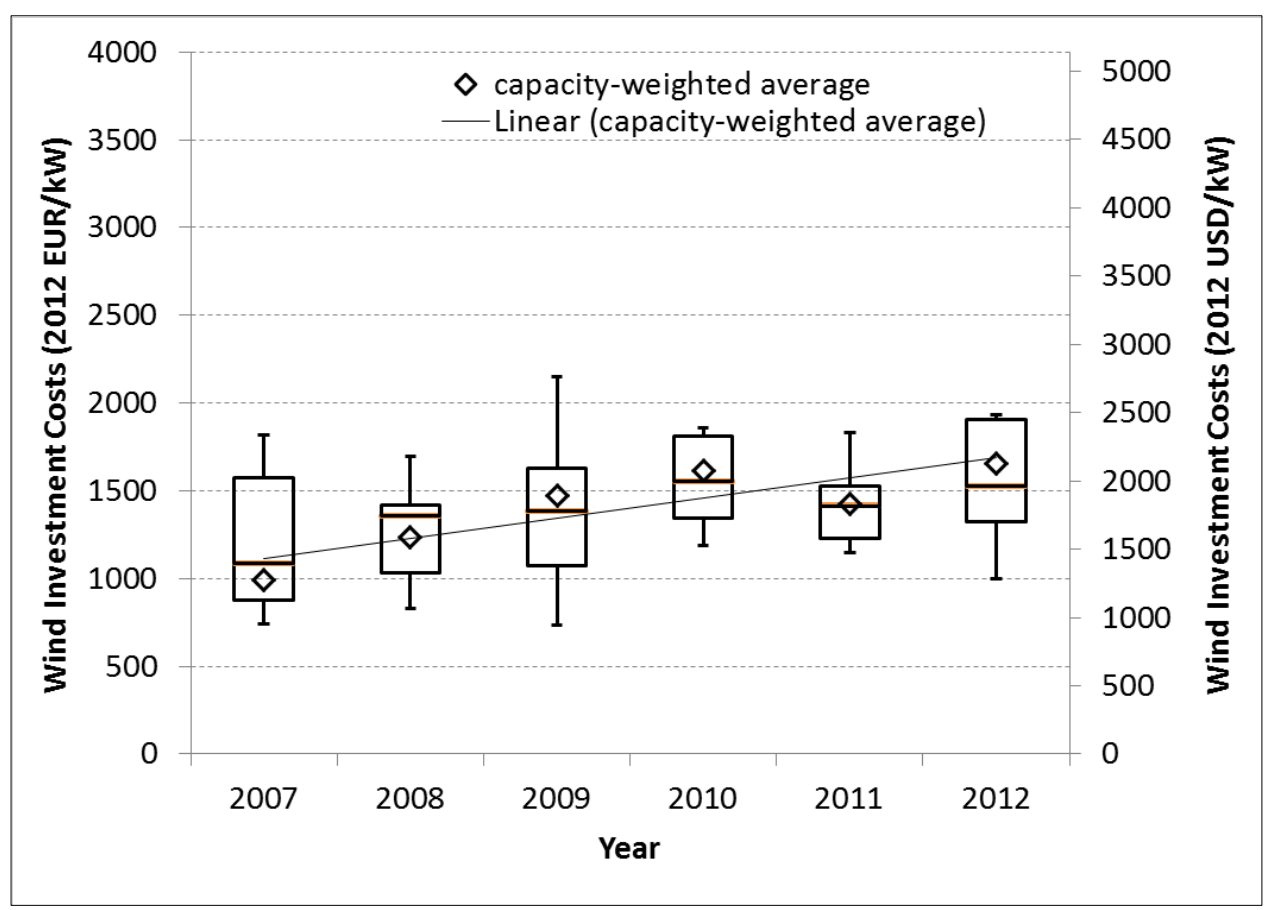

Figure 3-10. Investment costs for projects installed from 2007 to 2012

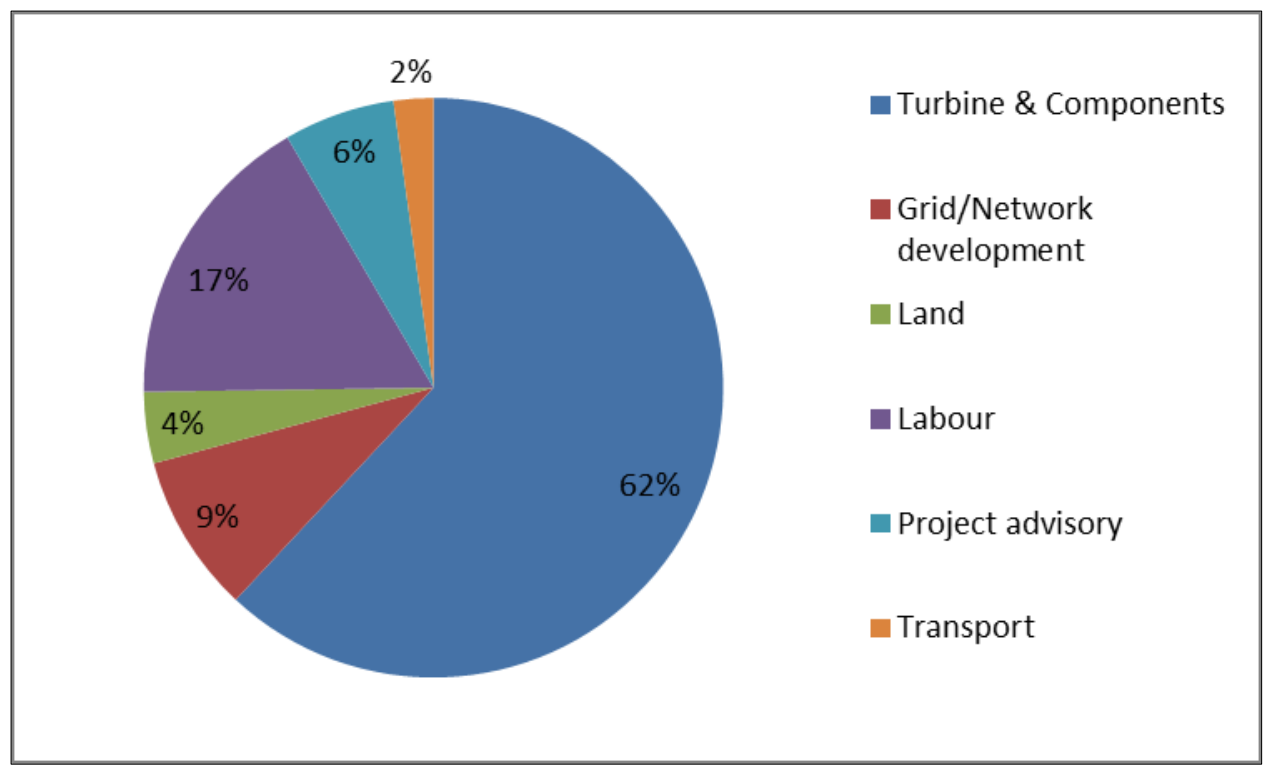

Figure 3-11. Breakdown of investment costs [20]

\section{Operations and Maintenance Costs}

There is very limited published data on the operation and maintenance (O\&M) costs of wind projects in Ireland and it did not prove possible to obtain reliable O\&M costs for individual wind projects. Average annual fixed O\&M costs for Irish wind projects were obtained from several sources including financial reports from the Irish Companies Registration Office, wind industry experts, wind plant O\&M providers, and literature [18]. 
In general, wind turbine maintenance and spare part costs do not have to be considered for at least the first two years of operation and sometimes for up to five, as they are generally covered by the wind turbine supplier contract warranty. However, during the first one to two years of operation there can be some maintenance and/or modifications required to get the wind project fully functional. For this analysis, an average fixed O\&M cost of $€ 55 / \mathrm{kW} / \mathrm{yr}$ was estimated between 2007 and 2012 over the 20 -year wind projects lifetime based primarily on industry sources. This includes land rent, maintenance by the turbine manufacturer, insurance, County Council rates and transmission use of system (TUOS) charges. ${ }^{42}$ Empirical evidence from the Irish wind energy industry suggests that since 2007 , O\&M costs have increased mainly due to land rent, County Council rates, and TUOS charges.

\section{Financing Costs}

During the period 2007-2012, there were a limited number of active lenders for wind projects in Ireland as a result of the great recession and a national financial crisis. Due to the financial crisis, lenders have been very selective in the project types and project developers they have financed. There is limited published data on financing costs for Irish wind projects and it did not prove possible to obtain these costs for individual projects. Based on interviews with major Irish lending institutions and a literature review, representative financing costs were obtained as shown in Table 3-2. All values are presented in after-tax nominal terms, but subsequent LCOE calculations are formulated in after-tax real terms. The return on equity was estimated to be $14 \%$ while $6 \%$ was taken as the interest rate on debt. Equity and debt shares of $20 \%$ and $80 \%$ are thought to have remained stable between 2007 and 2012. This produces an after-tax, nominal WACC of $7 \%^{43}$ for both 2008 and 2012 wind projects in Ireland.

Table 3-2. Wind Energy Financing Terms in Ireland

\begin{tabular}{|l|l|r|r|}
\hline & \multicolumn{2}{|c|}{2008} & \multicolumn{1}{|c|}{2012} \\
\hline Return on equity & $\%$ & 14 & 14 \\
\hline Return on debt & $\%$ & 6 & 6 \\
\hline Equity share & $\%$ & 20 & 20 \\
\hline Debt share & $\%$ & 80 & 80 \\
\hline Loan duration & (years) & 15 & 15 \\
\hline Corporate tax rate & $\%$ & 12.5 & 12.5 \\
\hline FX rate & (Currency/€) & 1.39 & 1.39 \\
\hline WACC (after-tax, nominal) & $\%$ & 7 & 7 \\
\hline
\end{tabular}

The main source of revenue for Irish wind projects in 2008 and 2012 is through the sale of electricity in the SEM. The REFIT reference price for wind projects in 2008 and 2012 is $€ 69.24 / \mathrm{MWh}$ (2012 prices). In addition to REFIT, suppliers are entitled to a balancing payment equivalent to $15 \%$ of the REFIT reference price to cover the cost of managing the short term variability of wind in the SEM. The amount of the balancing payment received by wind projects is subject to negotiation with the suppliers. It is assumed for this analysis that the wind projects

\footnotetext{
${ }^{42}$ TUOS are charges for the provision of access to the transmission network to transfer energy for trade in the market (http://www.eirgrid.com/media/20142015\%20Statement $\% 20$ of $\% 20$ Charges $\% 20$ CER $\% 20$ Approved\%20v1.0.pdf)

${ }^{43}$ After-tax, nominal WACC $=(1$-Debt share $) *$ Return on equity + Debt share*Return on debt* $(1-$ Corporate tax rate)
} 
receive $50 \%$ of the balancing payment based on empirical evidence from Irish wind industry sources. Therefore, wind projects in 2008 and 2012 receive $€ 74.43 / \mathrm{MWh}$ (2012 prices) in revenue over a 20 -year lifetime.

\section{Cost of Wind Energy Generation in Ireland in 2008 and 2012}

\section{Representative Wind Energy Project in 2008 and 2012}

The historical trends presented in the graphs in the previous sections provide an insight into the variations in technology, investment costs, $\mathrm{O} \& \mathrm{M}$ costs, energy production and financing costs in Ireland between 2007 and 2012. These parameters represent the elements required to calculate the LCOE of a typical wind project in Ireland in 2008 and 2012. The following section describes the estimation of LCOEs for projects which are typical of those installed in both 2008 and 2012.

\section{Model Input Assumptions}

The parameters for the typical wind projects in Ireland for 2008 and 2012 are taken as the trend averages from the data presented in the graphs in the previous sections. These are summarized in Table 3-3 and Table 3-4. As noted previously, average wind turbines in 2012 are larger than in 2008 , and the investment costs have increased. The expected increase in production from the larger turbines is mostly offset by the observed tendency to locate turbines in lower wind speed locations. As discussed earlier, due to lack of data, no variation in O\&M costs over the time period was assumed. Decommissioning costs are omitted, as very few wind projects in Ireland have reached their economic life and it is assumed the end-of-life costs and benefits will balance. As regards the WACC, given the European Central Bank's mandate of maintaining inflation close to $2 \%$, this projected long-run inflation rate was assumed, giving a real after-tax WACC of $4.9 \%{ }^{44}$

\footnotetext{
${ }^{44}$ After-tax, real WACC $=((1+$ nominal WACC $) /(1+$ inflation rate $))-1$
} 
Table 3-4. Wind Energy Project Features in Ireland

\begin{tabular}{|l|l|r|r|}
\hline & & 2008 & 2012 \\
\hline Unit size & $\mathrm{MW}$ & 1.5 & 2.1 \\
\hline Number of turbines & $\mathrm{N}$ & 9 & 6 \\
\hline Rotor Diameter / Hub height & $\mathrm{m} / \mathrm{m}$ & $64 / 58$ & $76 / 73$ \\
\hline Annual Average Wind Speed at hub height & $\mathrm{m} / \mathrm{s}$ & 8.5 & 8.2 \\
\hline Production & $($ full-load hours) & 2,653 & 3,194 \\
\hline Economic life & $($ years $)$ & 20 & 20 \\
\hline Investment costs & $\left(€_{2012} / \mathrm{kW}\right)$ & 1,226 & 1,689 \\
\hline O\&M costs fixed & $\left(€_{2012} / \mathrm{kW} / \mathrm{yr}\right)$ & 55 & 55 \\
\hline O\&M costs variable & $\left(€^{\mathrm{c}} / \mathrm{kWh}\right)$ & $\mathrm{N} / \mathrm{A}$ & $\mathrm{N} / \mathrm{A}$ \\
\hline Decommission costs & $(€ c t / \mathrm{kWh})$ & $\mathrm{N} / \mathrm{A}$ & $\mathrm{N} / \mathrm{A}$ \\
\hline WACC (after-tax, real) & $\%$ & 4.9 & 4.9 \\
\hline Corporate Tax Rate & $\%$ & 12.5 & 12.5 \\
\hline
\end{tabular}

The wind energy policy and revenue incentives in Ireland for the 2008 and 2012 typical wind projects are assumed to have remained the same. The wind project owners negotiate PPAs with electricity suppliers for the sale of electricity in the SEM in conjunction with the REFIT reference price. The PPAs are typically agreed for 15 years but may be re-negotiated and extended for an additional five years up to the 20-year lifetime of the projects. The re-negotiated PPA may also be based on a percentage of the SEM price but this is dependent on the wind project owners' bargaining power with the electricity suppliers. There is no published data available on the amounts suppliers agree to pay wind projects in Ireland for each unit of electricity produced under the re-negotiated PPA after 15 years. Although some industry sources indicate that $70-90 \%$ of the SEM price is received by the wind project, it has not been possible to verify this. Therefore, for this analysis the sole revenue stream for both projects is assumed to be the FIT revenue (REFIT reference price $+50 \%$ of balancing payment) which is $€ 0.074 / \mathrm{kWh}$ (2012 prices) over a 20-year lifetime as shown in Table 3-5. A 20-year straight-line depreciation of $100 \%$ of the investment costs is assumed and accelerated depreciation is not included in the LCOE estimates presented the following section. 
Table 3-5. Wind Energy Policy and Revenue Incentives in Ireland

\begin{tabular}{|c|c|c|c|}
\hline & & 2008 & 2012 \\
\hline Annual average market price of electricity & $€_{2012} / \mathrm{kWh}$ & 0.063 & 0.063 \\
\hline FIT revenue & $€_{2012} / \mathrm{kWh}$ & 0.074 & 0.074 \\
\hline FIT policy period & (years) & 20 & 20 \\
\hline \multicolumn{4}{|l|}{ Upfront tax-based } \\
\hline subsidy before tax & $\%$ & $\mathrm{~N} / \mathrm{A}$ & N/A \\
\hline \multicolumn{4}{|l|}{ Production-based before } \\
\hline tax credits & $€ / \mathrm{kWh}$ & $\mathrm{N} / \mathrm{A}$ & N/A \\
\hline \multicolumn{4}{|l|}{ Production-based before } \\
\hline tax credit policy period & (years) & $\mathrm{N} / \mathrm{A}$ & $\mathrm{N} / \mathrm{A}$ \\
\hline Depreciation period & (years) & 20 & 20 \\
\hline Reactive power bonus & $€ / \mathrm{kWh}$ & $\mathrm{N} / \mathrm{A}$ & $\mathrm{N} / \mathrm{A}$ \\
\hline \multicolumn{4}{|l|}{ Low voltage ride through } \\
\hline bonus & $€ / \mathrm{kWh}$ & $\mathrm{N} / \mathrm{A}$ & $\mathrm{N} / \mathrm{A}$ \\
\hline Market Certificates & $€ / k W h$ & $\mathrm{~N} / \mathrm{A}$ & N/A \\
\hline
\end{tabular}

\section{LCOE, Policy Incentives, and Required Revenue}

The LCOE is calculated for each project defined in the previous section using the cash flow model developed for use in IEA Wind Task 26; refer to Appendix 1 for further detail on the methodology. The LCOE for each typical project in 2008 and 2012 is shown in Figure 3-12 and Figure 3-13. The difference between the estimated LCOE and the value of policy is represented by the revenue required which represents the impact of the Irish REFIT support scheme. For the 2008 project, the LCOE of $€ 59.45 / \mathrm{MWh}$ is covered by $€ 74.43 / \mathrm{MWh}$ in the form of the REFIT reference price over the project's 20-year lifetime. The revenue required indicates the LCOE is covered by the REFIT reference price and the wind project is profitable by $€ 14.98 / \mathrm{MWh}$. Similarly, for the 2012 project, the LCOE of $€ 61.53 / \mathrm{MWh}$ is covered by $€ 74.43 / \mathrm{MWh}$ and is profitable by $€ 12.90 / \mathrm{MWh}$.

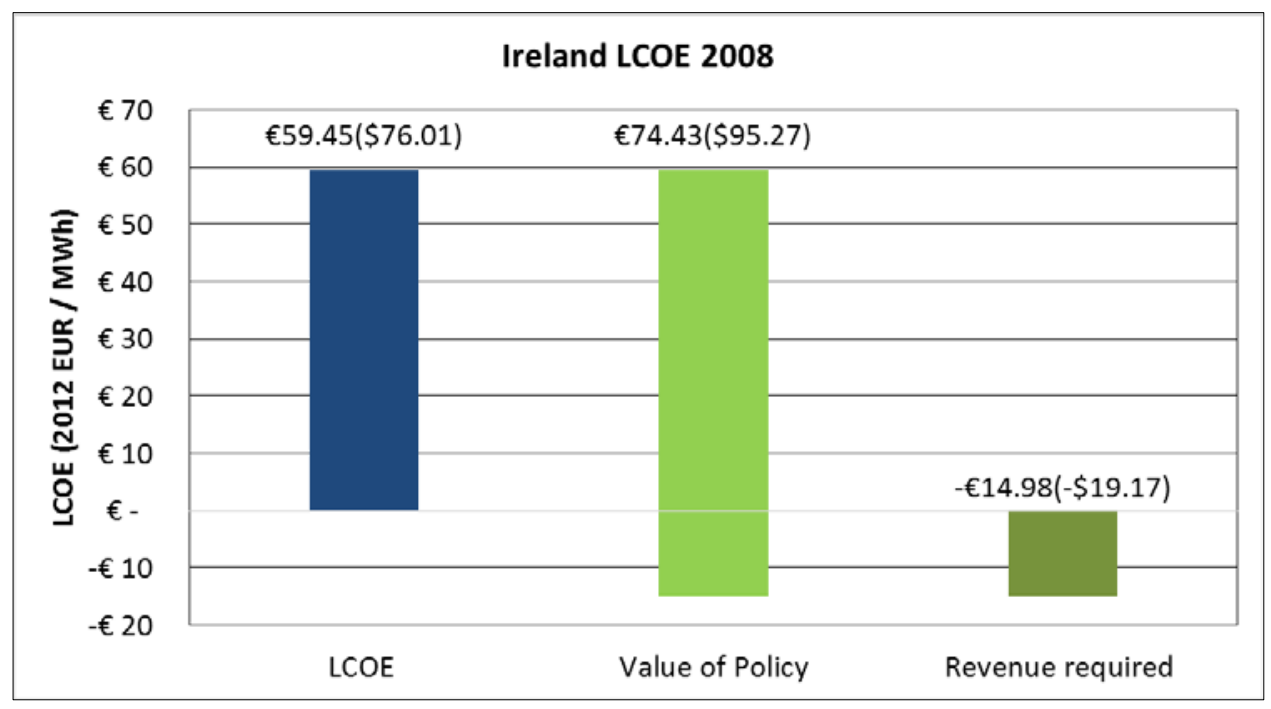

Figure 3-12. Wind energy revenue and policy incentives in Ireland in 2008 


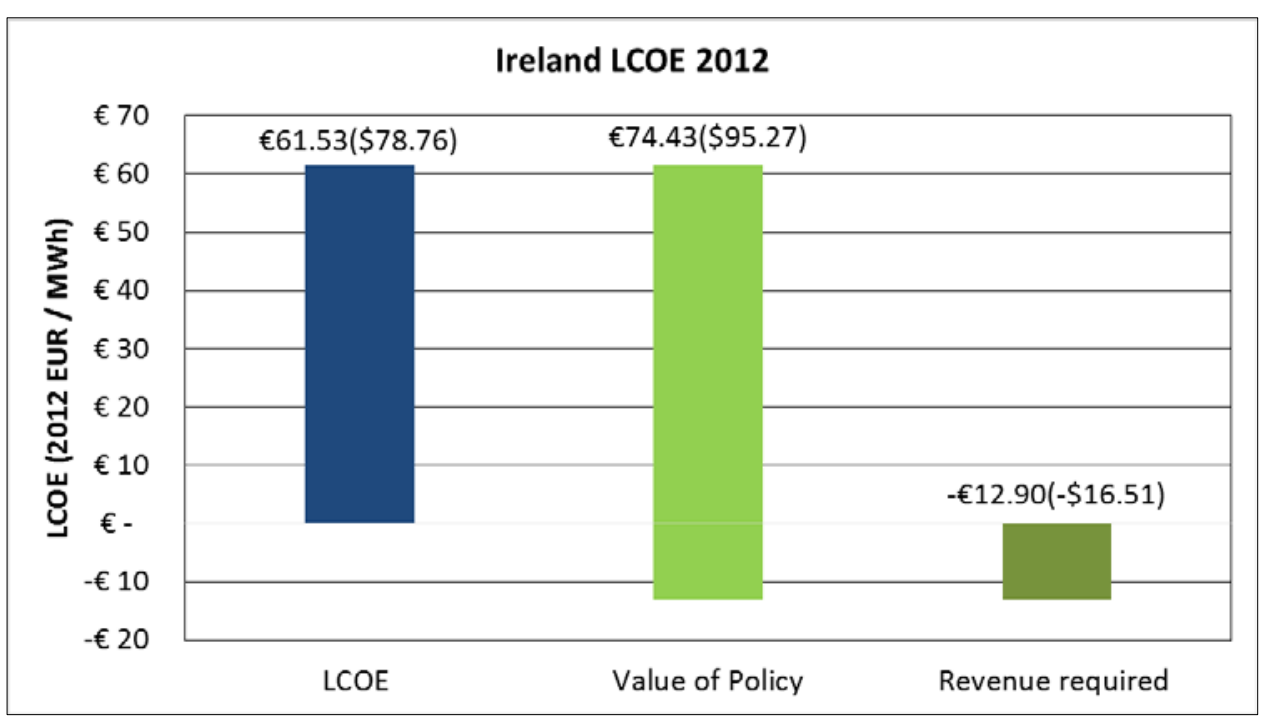

Figure 3-13. Wind energy revenue and policy incentives in Ireland in 2012

The LCOE, value of policy, and revenue required is shown in Table 3-6. It indicates for the typical wind projects in Ireland for 2008 and 2012, the LCOE is covered by the REFIT reference price over the project's 20-year lifetime. However, it should be noted, the LCOE and revenues of wind projects are always site- and project-specific with significant variations across projects. Therefore, the average values presented for this analysis may not fully capture all of the projectspecific variations particularly for single and small wind projects.

Table 3-6. Wind Plant LCOE Summary with Policy and Revenue Components

\begin{tabular}{|l|l|r|r|}
\hline & & \multicolumn{1}{|c|}{2008} & \multicolumn{1}{c|}{2012} \\
\hline Levelized cost of energy & $(€ / M W h)$ & 59.45 & 61.53 \\
\hline Levelized cost of energy & $(\$ / M W h)$ & 76.01 & 78.76 \\
\hline Value of policy & $(€ / M W h)$ & 74.43 & 74.43 \\
\hline Value of policy & $(\$ / M W h)$ & 95.27 & 95.27 \\
\hline Revenue Required & $(€ / M W h)$ & -14.98 & -12.90 \\
\hline Revenue Required & $(\$ / M W h)$ & -19.17 & -16.51 \\
\hline
\end{tabular}

\section{Summary of Wind Projects in Ireland}

Ireland is, on average, halfway toward meeting its 2020 targets, but it will require approximately 1,601 MW of installed wind capacity in the period 2014-2020 to fulfil its targets. The main trend observed for Irish wind projects was the increase in wind turbine capacity rating coinciding with increased rotor diameter and hub heights between 2007 and 2012. This increasing trend enabled wind projects to achieve generation-weighted average full-load hours varying from 2,250 to 3,000 . Investment costs increased between 2007 and 2012, ranging from $€ 990 / \mathrm{kW}$ to $€ 1,658 / \mathrm{kW}$ (2012 prices), respectively. O\&M costs remained stable, although it should be noted very limited published data for O\&M costs are available. Under these technical and financial features, typical Irish wind projects in 2008 and 2012 achieved LCOEs of $€ 59.45 / \mathrm{MWh}$ and $€ 61.53 / \mathrm{MWh}$, respectively. At these LCOE levels and with the REFIT support scheme available, Ireland remains attractive for wind project investment and development. However, the LCOE of wind 
projects are always site- and project-specific with significant variations across projects.

Therefore, the average values presented in this chapter may not capture all of the project specific variations.

In terms of future trends, several projects in 2014 will be located in the midlands of Ireland where suitable land for wind project development is available. These areas of land tend to have lower wind speeds and may require low specific power turbines in order to ensure financial viability. It has been suggested by industry sources that investment costs may vary between $€ 1,400 / \mathrm{kW}$ and $€ 1,600 / \mathrm{kW}$ for large-scale (>5MW) wind projects in 2014. Beyond 2014, uncertainty for planned wind projects exists in the form of the implementation of the proposed Integrated Single Electricity Market (I-SEM) by 2018 and Eirgrid's DS3 and Grid 25 programs. Under the I-SEM, wind projects will be exposed to forecast risk induced by the requirement to balance the deviations between their scheduled position in the day-ahead or intra-day markets and actual generation in the balancing (real time) market. Moreover, the on-time delivery of the DS3 and Grid 25 programs is essential in order to minimize curtailment and constraint of wind production. This will impose both production and financial risk on wind projects going forward.

\section{References for Chapter 3}

[1] Department of Communications, Energy and Natural Resources, "National Renewable Energy Action Plan,” 2009.

[2] European Parliament, Directive 2009/28/EC of the European Parliament and of the council of the European Union on the promotion of the use of energy from renewable sources. European Parliament, 2009, pp. 16-62.

[3] M. Howley, M. Holland, and D. Dineen, "Energy in Ireland 1990-2013," 2014.

[4] Eirgrid and SONI, “All-Island Generation Capacity Statement 2015-2024,” 2015.

[5] Department of Communications, Energy and Natural Resources, "Electricity from Renewables inc REFIT and AER." [Online]. Available:

http://www.dcenr.gov.ie/Energy/Sustainable+and+Renewable+Energy+Division/Electricity+fro $\mathrm{m}+$ Renewables + inc + REFIT + and + AER + Change + me.htm. [Accessed: 09-Aug-2014].

[6] C. Devitt and L. M. Valeri, "The Effect of REFIT on Irish Wholesale," The Economic and Social Review, vol. 42, no. 3, pp. 343-369, 2011.

[7] Department of Communications, Energy and Natural Resources, "REFIT." [Online]. Available:

http://www.dcenr.gov.ie/Energy/Sustainable+and+Renewable+Energy+Division/REFIT.htm. [Accessed: 09-Aug-2014].

[8] Commission for Energy Regulation, "Public Service Obligation Levy 2012/2013,” 2013.

[9] M. Clancy and F. Gaffney, "Quantifying Ireland's Fuel and CO2 Emissions Savings from Renewable Electricity in 2012," Dublin, 2014.

[10] R. Doherty and M. O'Malley, "The efficiency of Ireland's Renewable Energy Feed-In Tariff (REFIT) for wind generation,” Energy Policy, vol. 39, no. 9, pp. 4911-4919, 2011.

[11] Revenue, "Trades, IT 55-The Employment and Investment Incentive (EII) - Relief for Investment in Corporate." [Online]. Available: http://www.revenue.ie/en/tax/it/leaflets/it55.html. [Accessed: 09-Aug-2014].

[12] Sustainable Energy Authority of Ireland, "Accelerated Capital Allowance." [Online]. Available: http://www.seai.ie/Your_Business/Accelerated_Capital_Allowance/. [Accessed: 09Aug-2014]. 
[13] Sustainable Energy Authority of Ireland, "Sustainable Energy Research, Demonstration \& Development Programme." [Online]. Available:

http://www.seai.ie/Grants/Renewable_Energy_RD_D/. [Accessed: 09-Aug-2014].

[14] Department of Communications, Energy and Natural Resources, "Delivering a

Sustainable Energy Furture in Ireland," 2007.

[15] IWEA, "Irish Wind Energy Association." [Online]. Available:

http://www.iwea.com/_windenergy_onshore. [Accessed: 20-Sep-2014].

[16] Eirgrid, "Eirgrid." [Online]. Available: http://www.eirgrid.com/. [Accessed: 20-Sep2014].

[17] CRO, “Company Registrations Office.” [Online]. Available: https://www.cro.ie/. [Accessed: 20-Sep-2014].

[18] Frontier Economics, "International support for onshore wind," 2013.

[19] Sustainable Energy Authority of Ireland, "SEAI Wind Atlas." [Online]. Available:

http://maps.seai.ie/wind/. [Accessed: 31-Aug-2014].

[20] J. FitzGerald, E. Denny, and A. O'Mahoney, "An Enterprising Wind: An Economic Analysis of the Job Creation Potential of the Wind Sector in Ireland," 2014. 


\title{
Appendix 3-A. Sample Size, Project Data, and Methodology for Ireland
}

This appendix contains statistics representing wind project characteristics that are illustrated in the chapter. Table 3-7 describes the sample size of data represented in the subsequent tables. The values in the table correspond to the installed wind project capacity in a given year, or the percentage of annual installed capacity, that is included in the database. For example, an entry of $100 \%$ for Wind Turbine Hub Height means that the statistics shown in the corresponding table and figure for hub height represent $100 \%$ of the turbines installed in that year.

Table 3-7. Sample Size for Ireland

\begin{abstract}
COUNTRY: IRELAND
DEFINITION OF UTILITY SCALE WIND

Wind farm project size $>10 \mathrm{MW}$ are obliged to participate in the Single Electricity Market(SEM) in Ireland. But there are exceptions for wind farms to participate in the SEM < $10 \mathrm{MW}$ if desired, as such it is a commercial decision (i.e. if they are willing to pay the market fees and undertake the registration process). For the total sample size 1,022 MW,2007-2012, there is $772 \mathrm{MW}$ In-market and $250 \mathrm{MW}$ Non-market. We have set a wind turbine size threshold $\geq 660 \mathrm{~kW}$
\end{abstract}

YEAR DATA AGGREGATION

OTHER NOTES

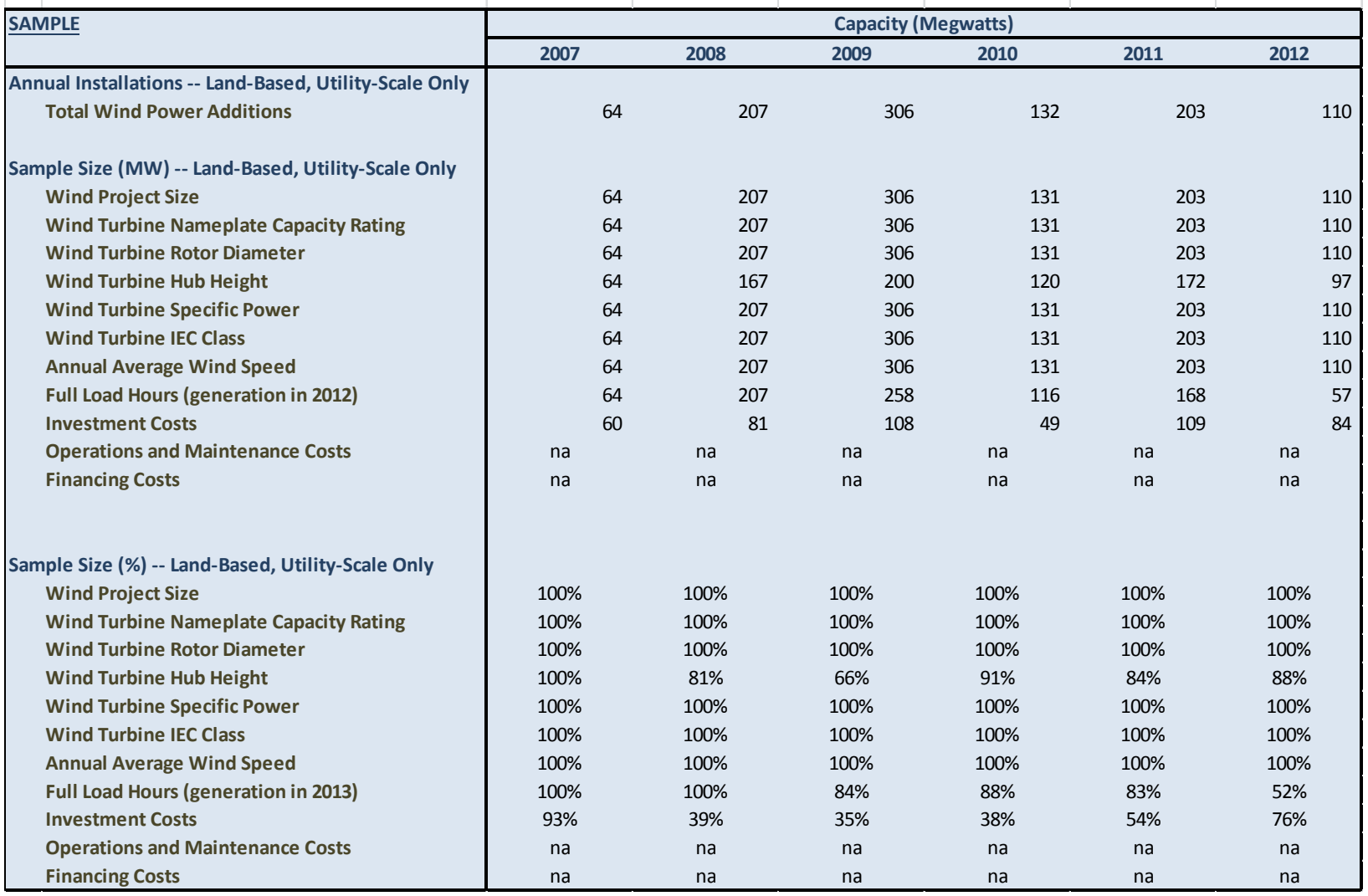


Table 3-8. Wind Project Size Statistics

\begin{tabular}{|c|c|c|c|c|c|c|}
\hline \multicolumn{7}{|c|}{ Wind Project Size (MW) } \\
\hline & 2007 & 2008 & 2009 & 2010 & 2011 & 2012 \\
\hline$n(M W)$ & 64 & 207 & 306 & 131 & 203 & 110 \\
\hline n (\# projects) & 6 & 12 & 21 & 10 & 19 & 8 \\
\hline median & 7.5 & 16.7 & 6.9 & 10.1 & 9.2 & 10.8 \\
\hline 25th percentile & 4.1 & 5.9 & 4.0 & 2.6 & 4.5 & 5.0 \\
\hline 75th percentile & 15.6 & 24.8 & 23.5 & 16.1 & 14.4 & 24.1 \\
\hline minimum & 2.7 & 1.7 & 1.8 & 1.7 & 0.7 & 3.2 \\
\hline maximum & 32.5 & 41.4 & 57.0 & 52.0 & 41.4 & 30.7 \\
\hline average & 10.7 & 17.3 & 14.6 & 13.1 & 10.7 & 13.7 \\
\hline
\end{tabular}

\section{Salient Notes: All projects $\geq 660 \mathrm{~kW}$, with all turbines $\geq 660 \mathrm{~kW}$}

Table 3-9. Turbine Nameplate Capacity Statistics

\begin{tabular}{|l|r|r|r|r|r|r|} 
Wind Turbine Nameplate Capacity Rating (MW) \\
\hline & 2007 & 2008 & 2009 & 2010 & 2011 & 2012 \\
\hline $\mathrm{n}$ (MW) & 64 & 207 & 306 & 131 & 203 & 110 \\
\hline $\mathrm{n}$ (\# turbines) & 55 & 116 & 169 & 95 & 98 & 48 \\
\hline median & 0.85 & 2.00 & 1.50 & 0.90 & 2.30 & 2.30 \\
\hline 25th percentile & 0.85 & 1.50 & 1.50 & 0.90 & 0.90 & 2.30 \\
\hline 75th percentile & 1.50 & 2.30 & 2.30 & 2.00 & 2.50 & 2.50 \\
\hline minimum & 0.85 & 0.85 & 0.80 & 0.80 & 0.66 & 0.85 \\
\hline maximum & 2.30 & 2.50 & 3.00 & 2.50 & 2.73 & 3.00 \\
\hline average & 1.17 & 1.79 & 1.81 & 1.38 & 1.91 & 2.30 \\
\hline mode & 0.85 & 1.50 & 1.50 & 0.90 & 2.30 & 2.30 \\
\hline
\end{tabular}

Table 3-10. Turbine Rotor Diameter Statistics

\begin{tabular}{|l|r|r|r|r|r|r|} 
Wind Turbine Rotor Diameter $(\mathbf{m})$ \\
\hline $\mathrm{n}$ (MW) & 2007 & 2008 & 2009 & 2010 & 2011 & 2012 \\
\hline $\mathrm{n}$ (\# turbines) & 64 & 207 & 306 & 131 & 203 & 110 \\
\hline median & 55 & 116 & 169 & 95 & 98 & 48 \\
\hline 25th percentile & 52.0 & 70.5 & 70.5 & 52.0 & 80.0 & 82.0 \\
\hline 75th percentile & 52.0 & 70.0 & 70.0 & 44.0 & 51.0 & 71.0 \\
\hline minimum & 70.0 & 71.0 & 90.0 & 80.0 & 82.0 & 90.0 \\
\hline maximum & 44.0 & 44.0 & 48.0 & 44.0 & 44.0 & 52.0 \\
\hline average & 77.0 & 90.0 & 90.0 & 90.0 & 100.0 & 90.0 \\
\hline
\end{tabular}

Salient Notes: All projects $\geq 660 \mathrm{~kW}$, with all turbines $\geq 660 \mathrm{~kW}$ 
Table 3-11. Turbine Specific Power Statistics

\begin{tabular}{|l|r|r|r|r|r|r|}
\hline \multicolumn{7}{|l|}{ Wind Turbine Specific Power $\left(\mathbf{W} / \mathbf{m}^{2}\right)$} \\
\hline & 2007 & 2008 & 2009 & 2010 & 2011 & 2012 \\
\hline $\mathrm{n}(\mathrm{MW})$ & 64 & 207 & 306 & 131 & 203 & 110 \\
\hline $\mathrm{n}$ (\# turbines) & 55 & 116 & 169 & 95 & 98 & 48 \\
\hline median & 400 & 431 & 393 & 400 & 418 & 436 \\
\hline 25th percentile & 400 & 384 & 384 & 400 & 393 & 393 \\
\hline 75th percentile & 400 & 505 & 434 & 400 & 517 & 581 \\
\hline minimum & 384 & 384 & 314 & 400 & 318 & 283 \\
\hline maximum & 592 & 592 & 581 & 400 & 592 & 581 \\
\hline average & 441 & 451 & 411 & 400 & 444 & 480 \\
\hline
\end{tabular}

Salient Notes: All projects $\geq 660 \mathrm{~kW}$, with all turbines $\geq 660 \mathrm{~kW}$

Table 3-12. Turbine Hub Height Statistics

\begin{tabular}{|l|r|r|r|r|r|r|}
\multicolumn{6}{|c|}{ Wind Turbine Hub Height $(\mathrm{m})$} \\
\hline & 2007 & 2008 & 2009 & 2010 & 2011 & 2012 \\
\hline $\mathrm{n}(\mathrm{MW})$ & 64 & 167 & 200 & 120 & 172 & 97 \\
\hline $\mathrm{n}$ (\# turbines) & 55 & 96 & 121 & 82 & 92 & 42 \\
\hline median & 45.0 & 64.7 & 65.0 & 55.8 & 70.0 & 80.0 \\
\hline 25th percentile & 45.0 & 54.8 & 56.0 & 55.5 & 55.0 & 64.0 \\
\hline 75th percentile & 54.7 & 65.0 & 65.0 & 67.0 & 84.0 & 80.0 \\
\hline minimum & 45.0 & 49.0 & 49.0 & 45.0 & 45.0 & 60.0 \\
\hline maximum & 64.0 & 78.0 & 95.0 & 80.0 & 85.0 & 84.0 \\
\hline average & 49.5 & 61.3 & 66.3 & 61.1 & 69.5 & 73.1 \\
\hline
\end{tabular}

Salient Notes: All projects $\geq 660 \mathrm{~kW}$, with all turbines $\geq 660 \mathrm{~kW}$

Table 3-13. Wind Turbine IEC Class Statistics

\begin{tabular}{|l|c|c|c|c|c|c|}
\hline \multicolumn{1}{|l|}{ Wind Turbine IEC Class - Average Class } \\
\hline & 2007 & 2008 & 2009 & 2010 & 2011 & 2012 \\
\hline $\mathrm{n}(\mathrm{MW})$ & 64 & 207 & 306 & 131 & 203 & 110 \\
\hline Class I & $16.5 \%$ & $25.0 \%$ & $10.0 \%$ & $50.0 \%$ & $30.0 \%$ & $14.0 \%$ \\
\hline Class I/II & $67.0 \%$ & $50.0 \%$ & $48.0 \%$ & $30.0 \%$ & $35.0 \%$ & $43.0 \%$ \\
\hline Class II & $16.5 \%$ & $25.0 \%$ & $27.0 \%$ & $20.0 \%$ & $30.0 \%$ & $43.0 \%$ \\
\hline Class II/III & $0.0 \%$ & $0.0 \%$ & $5.0 \%$ & $0.0 \%$ & $5.0 \%$ & $0.0 \%$ \\
\hline Class III & $0.0 \%$ & $0.0 \%$ & $10.0 \%$ & $0.0 \%$ & $0.0 \%$ & $0.0 \%$ \\
\hline Average & 1.5 & 1.5 & 1.8 & 1.4 & 1.6 & 1.6 \\
\hline $\mathrm{n}$ (\# turbines) & 56 & 116 & 169 & 95 & 98 & 48 \\
\hline
\end{tabular}

Salient Notes: All projects $\geq 660 \mathrm{~kW}$, with all turbines $\geq 660 \mathrm{~kW}$. Turbines rated as spanning two classes are identified as such (e.g., Class II/III) and an "average" class is defined for the purpose of showing trends in the average IEC Class (e.g., a Class II/III machine is given an average class of 2.5) 
Table 3-14. Annual Average Wind Speed Statistics

Average Annual Wind Speed
\begin{tabular}{|l|r|r|r|r|r|r|}
\hline & 2007 & 2008 & 2009 & 2010 & 2011 & 2012 \\
\hline $\mathrm{n}$ (MW) & 64 & 207 & 306 & 131 & 203 & 110 \\
\hline $\mathrm{n}$ (\# turbines) & 6 & 12 & 21 & 10 & 19 & 8 \\
\hline median & 8.7 & 8.7 & 8.5 & 8.7 & 8.3 & 8.1 \\
\hline 25th percentile & 7.2 & 8.2 & 7.8 & 7.8 & 8.0 & 7.3 \\
\hline 75th percentile & 9.2 & 9.1 & 9.1 & 9.3 & 8.9 & 8.7 \\
\hline minimum & 7.1 & 7.7 & 6.6 & 7.2 & 6.6 & 6.8 \\
\hline maximum & 9.5 & 9.4 & 11.2 & 9.6 & 9.9 & 8.8 \\
\hline average & 8.4 & 8.7 & 8.5 & 8.6 & 8.4 & 8.0 \\
\hline
\end{tabular}

Table 3-15. Full Load Hours/Capacity Factor Statistics

\begin{tabular}{|c|c|c|c|c|c|c|}
\hline \multicolumn{7}{|c|}{ Full Load Hours in 2013 (equivalent to capacity factor * 8784(leap year) * 8760(normal year)) } \\
\hline Project COD & 2007 & 2008 & 2009 & 2010 & 2011 & 2012 \\
\hline$n(M W)$ & 64 & 207 & 258 & 116 & 168 & 57 \\
\hline median & 2,348 & 2,243 & 2,626 & 2,528 & 3,147 & 2,447 \\
\hline 25th percentile & 1,397 & 1,401 & 1,435 & 1,625 & 2,498 & 2,439 \\
\hline 75th percentile & 2,655 & 2,662 & 3,193 & 3,107 & 3,273 & 3,383 \\
\hline minimum & 1,321 & 1,325 & 573 & 1,403 & 527 & 2,439 \\
\hline maximum & 3,273 & 3,282 & 3,944 & 3,944 & 3,558 & 3,383 \\
\hline generation-weighted average & 2,247 & 2,629 & 3,113 & 2,642 & 3,071 & 3,027 \\
\hline
\end{tabular}

\section{Capacity Factor in 2013 (equivalent to full load hours divided by 8784)}

\begin{tabular}{|l|c|c|c|c|c|c|}
\hline & 2007 & 2008 & 2009 & 2010 & 2011 & 2012 \\
\hline median & $26.8 \%$ & $25.5 \%$ & $30.0 \%$ & $28.9 \%$ & $35.9 \%$ & $27.9 \%$ \\
\hline 25th percentile & $15.9 \%$ & $15.9 \%$ & $16.4 \%$ & $18.6 \%$ & $28.5 \%$ & $27.8 \%$ \\
\hline 75 th percentile & $30.3 \%$ & $30.3 \%$ & $36.5 \%$ & $35.5 \%$ & $37.4 \%$ & $38.5 \%$ \\
\hline minimum & $15.1 \%$ & $15.1 \%$ & $6.5 \%$ & $16.0 \%$ & $6.0 \%$ & $27.8 \%$ \\
\hline maximum & $37.4 \%$ & $37.4 \%$ & $45.0 \%$ & $45.0 \%$ & $40.6 \%$ & $38.5 \%$ \\
\hline average & $25.0 \%$ & $25.0 \%$ & $28.2 \%$ & $28.9 \%$ & $32.5 \%$ & $31.4 \%$ \\
\hline capacity-weighted average & $22.0 \%$ & $23.3 \%$ & $32.8 \%$ & $28.7 \%$ & $37.9 \%$ & $33.6 \%$ \\
\hline generation-weighted average & $25.7 \%$ & $29.9 \%$ & $35.5 \%$ & $30.2 \%$ & $35.1 \%$ & $34.5 \%$ \\
\hline
\end{tabular}


Table 3-16. Investment Costs Statistics

Wind Project Investment Costs (2012 EUR per kW)
\begin{tabular}{|l|r|r|r|r|r|r|}
\hline & 2007 & 2008 & 2009 & 2010 & 2011 & 2012 \\
\hline $\mathrm{n}(\mathrm{MW})$ & 60 & 81 & 108 & 49 & 109 & 84 \\
\hline median & 1084 & 1355 & 1383 & 1551 & 1413 & 1526 \\
\hline 25th percentile & 877 & 1029 & 1074 & 1344 & 1232 & 1324 \\
\hline 75th percentile & 1577 & 1416 & 1629 & 1813 & 1523 & 1903 \\
\hline minimum & 739 & 831 & 733 & 1188 & 1150 & 996 \\
\hline maximum & 1815 & 1696 & 2147 & 1858 & 1834 & 1930 \\
\hline average & 1199 & 1278 & 1425 & 1573 & 1415 & 1551 \\
\hline capacity-weighted average & 990 & 1237 & 1472 & 1614 & 1427 & 1658 \\
\hline
\end{tabular}

Wind Project Investment Costs (2012 USD per kW)
\begin{tabular}{|l|r|r|r|r|r|r|}
\hline & 2007 & 2008 & 2009 & 2010 & 2011 & 2012 \\
\hline median & 1,394 & 1,743 & 1,778 & 1,994 & 1,817 & 1,961 \\
\hline 25th percentile & 1,128 & 1,323 & 1,381 & 1,728 & 1,583 & 1,702 \\
\hline 75th percentile & 2,028 & 1,820 & 2,094 & 2,330 & 1,958 & 2,447 \\
\hline minimum & 951 & 1,068 & 942 & 1,527 & 1,478 & 1,280 \\
\hline maximum & 2,333 & 2,180 & 2,761 & 2,389 & 2,358 & 2,481 \\
\hline capacity-weighted average & 1,273 & 1,590 & 1,892 & 2,076 & 1,834 & 2,131 \\
\hline
\end{tabular}




\section{Production Index Methodology}

1. All figures based on yearly metered electricity output (Production Index calc. 080714) from 143 Irish wind plants operating during various time periods 2002-2013.

2. Annual wind plant output data filtered based on $5 \%$ and $95 \%$ percentile capacity factor (CF) thresholds $(0.09>\mathrm{CF}<0.43)$; from this filtered data wind plants with less than the threshold number of years (five years) of operation are omitted from the index.

3. Annual wind plant production indices (PI) are calculated according to:

$$
P I_{x, i}=E_{x, i} / \overline{E_{x, l}}
$$

where:

$P I_{x, i}$ is the annual production index for wind plant $\mathrm{x}$ in year $i$;

$\overline{E_{x, l}}$ is the average metered electricity output for the wind plant in year $i$ given by:

$$
\overline{E_{x, l}}=\sum_{i=1}^{n} E_{x, i} / n
$$

Where:

$n$ is the total number of years of operation of wind plant $x$.

4. The All-Island of Ireland PI for each year is the average of all sample wind plant PIs weighted by their rated capacity:

$$
P I_{i}=R C_{x} \sum_{x=1}^{j} P I_{x, i} / j
$$

where:

$P I_{i}$ is the sample production index for year $i$;

$j$ is the number of wind plants with more than 5 years of annual output; and

$R C_{x}$ is the rated capacity of wind plant $\mathrm{x}$. 


\section{Chapter 4. Wind Energy Development in Norway}

Authors: Leif I. Husabø and David E. Weir, Norwegian Water Resources and Energy Directorate (NVE)

This chapter should be cited as: Husabø, L. and Weir, D. (2015). "Wind Energy Development in Norway," Chapter 4. Hand, M. M., ed., IEA Wind Task 26 - Wind Technology, Cost, and Performance Trends in Denmark, Germany, Ireland, Norway, the European Union, and the United States: 2007-2012. NREL/TP-6A20-64332. Golden, CO: National Renewable Energy Laboratory. pp. 101-120.

\section{Domestic Wind Energy Capacity, Production, and Targets}

Norway has long relied on its extensive hydropower resources to meet, and often exceed, its electricity demand. In the late 1990s public discussion began to focus on Norway's vast wind resources as another source for renewable energy and various public support schemes have led to the construction of more than $800 \mathrm{MW}$ of wind power in Norway after the year 2000. Wind power deployment in Norway is shown graphically and in table form in Figure 4-1 and Table 4-1 below.

\section{Revenue and Policy Incentives}

From 2001 to 2010, financial support for wind power projects in Norway was provided by the state-owned organization Enova SF, on a case-by-case basis with the goal to support projects just enough to make them commercially viable. This program was terminated in 2011, and followed by the Norwegian-Swedish electricity certificate scheme. Since 2012, Enova has focused on supporting earlier phases of technology development connected to wind power and other renewables, although the last wind power project to receive funding from Enova was not fully commissioned until 2013.

Since 1 January 2012, Sweden and Norway have had a common market for electricity certificates. It is based upon the Swedish electricity certificate scheme, which has been in place since 2003. The goal of the joint electricity certificate market is to increase the annual renewable electricity production in both countries combined by $26.4 \mathrm{TWh}$ by the end of 2020 . This represents approximately $10 \%$ of the current electricity production of the two countries. Norway and Sweden are each responsible for financing half of the new production in the certificate system, regardless of where the new production capacity is established. The electricity certificate scheme will contribute to the achievement of the countries' goals under the EU's Renewable Energy Directive. The common electricity certificate market is due to continue through the end of 2035 . 


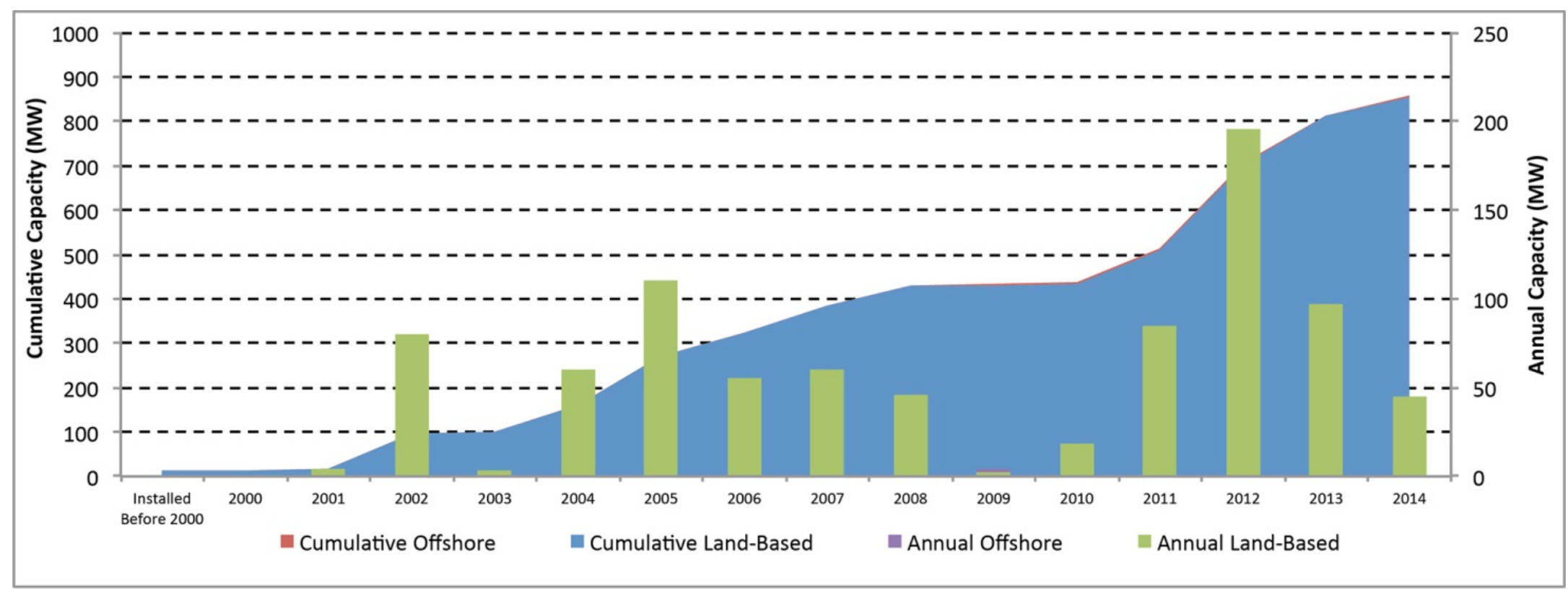

Figure 4-1. Cumulative and annual wind installations in Norway

Table 4-1. Cumulative and Annual Capacity (GW) Installed in Norway

\begin{tabular}{|c|c|c|c|c|c|c|c|c|c|c|c|c|c|c|c|c|c|}
\hline \multicolumn{18}{|c|}{ Vind Project Capacity and Targets (GW) } \\
\hline & & $<2000$ & 2000 & 2001 & 2002 & 2003 & 2004 & 2005 & 2006 & 2007 & 2008 & 2009 & 2010 & 2011 & 2012 & 2013 & 2014 \\
\hline Cums & Land-Based & 13.0 & 13 & 17 & 97 & 100 & 160 & 270 & 325 & 385 & 430.5 & 430.9 & 434.6 & 511.5 & 704 & 811 & 856 \\
\hline Cumulative & Offshore & 0.0 & 0.0 & 0.0 & 0.0 & 0.0 & 0.0 & 0.0 & 0.0 & 0.0 & 0.0 & 2.3 & 2.3 & 2.3 & 2.3 & 2.3 & 2.3 \\
\hline Annual & Land-Based & 0.0 & 0 & 4 & 80 & 3 & 60 & 110 & 55 & 60 & 45.5 & 2.3 & 18.4 & 85.1 & 195.3 & 97.5 & 45 \\
\hline Annual & Offshore & 0.0 & 0.0 & 0.0 & 0.0 & 0.0 & 0.0 & 0.0 & 0.0 & 0.0 & 0.0 & 2.3 & 0.0 & 0.0 & 0.0 & 0.0 & 0.0 \\
\hline
\end{tabular}




\section{Wind Energy Project Trends in Norway since 2007}

The Norwegian Water Resources and Energy Directorate (NVE) is tasked with maintaining databases for all licensed power plants in Norway. Wind power plants must be licensed if they deliver electricity to power lines of $1,000 \mathrm{~V}$ or higher, which in practice means that data are available for all but a few very small $(<500 \mathrm{~kW})$ single wind turbines. Wind power plants in Norway tend to consist of several wind turbines larger than $2 \mathrm{MW}$ in size. In addressing technical and financial aspects of wind power plants in 2007 and 2012 it has been necessary to aggregate several years of data, both to obtain a large enough sample and to avoid revealing commercially sensitive information on a project-specific basis.

To represent the year 2007 it was decided to combine data from three plants commissioned in 2006-2008, for a total sample size of $108 \mathrm{MW}$. Due to relatively high deployment in the years 2011-2013, this sample was larger (348 MW), but after consideration of the projects involved it was still decided to use data from all three years to increase sample size. For each wind power plant investment cost, annual energy production (AEP), and technical details such as turbine types and long term expectations for mean wind speeds at hub height were available. For ease of reading these two groups of projects will hereafter be referred to as 2007 and 2012 projects. In addition to project trends from 2007 to 2012 which are based upon existing projects, this chapter presents a theoretical reference project for 2014. This project is included to represent trends after 2012 in Norwegian wind power development, as well as to illustrate the effect of the NorwegianSwedish Electricity Certificate Scheme which is the support scheme for wind power built after 2012.

Project-specific data were not available for financing structures or O\&M costs. These were instead estimated based upon limited data and general input from the Norwegian Wind Energy Association (NORWEA) and lending institutions.

\section{Project Features}

Wind plants built around 2012 tended to be larger in size, 39-110 MW compared with 11.5-57.5 MW for 2007 projects. Turbine nameplate capacity also increased, from 2.3 MW for all 2007 wind turbines to an average of $2.5 \mathrm{MW}$ in 2012, with one project (Fakken wind plant) consisting of 3-MW wind turbines. These two trends are illustrated in Figures 4-2 and 4-3 below. Other countries use a box and whiskers format to represent the projects or turbines that achieved commercial operation in a given period including the median (horizontal line), average (diamond), $25^{\text {th }}$ to $75^{\text {th }}$ percentile (box), and minimum and maximum (whiskers). Due to the small sample size for Norway, only minimum, maximum, and average values are presented in the figures, where the averages are marked with diamonds. 


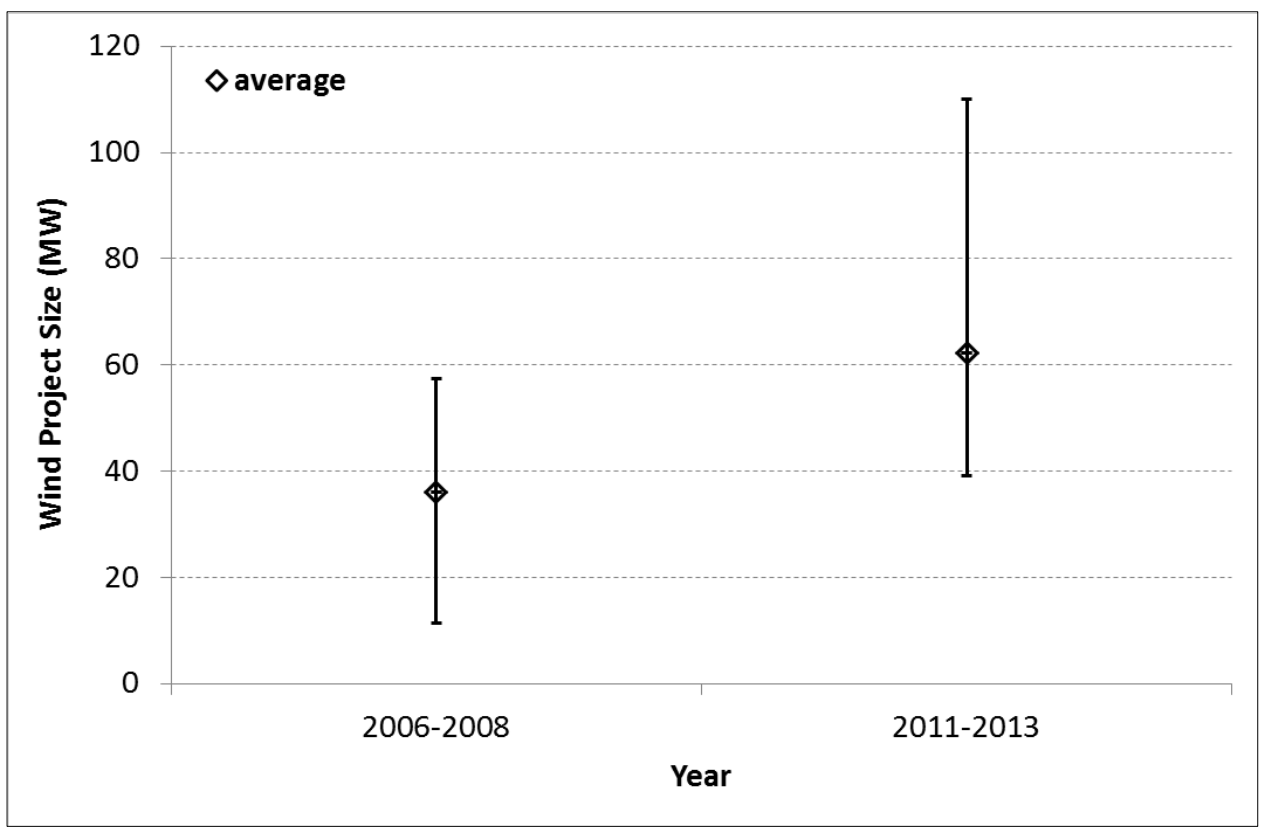

Figure 4-2. Wind project size trends from 2007 to 2012

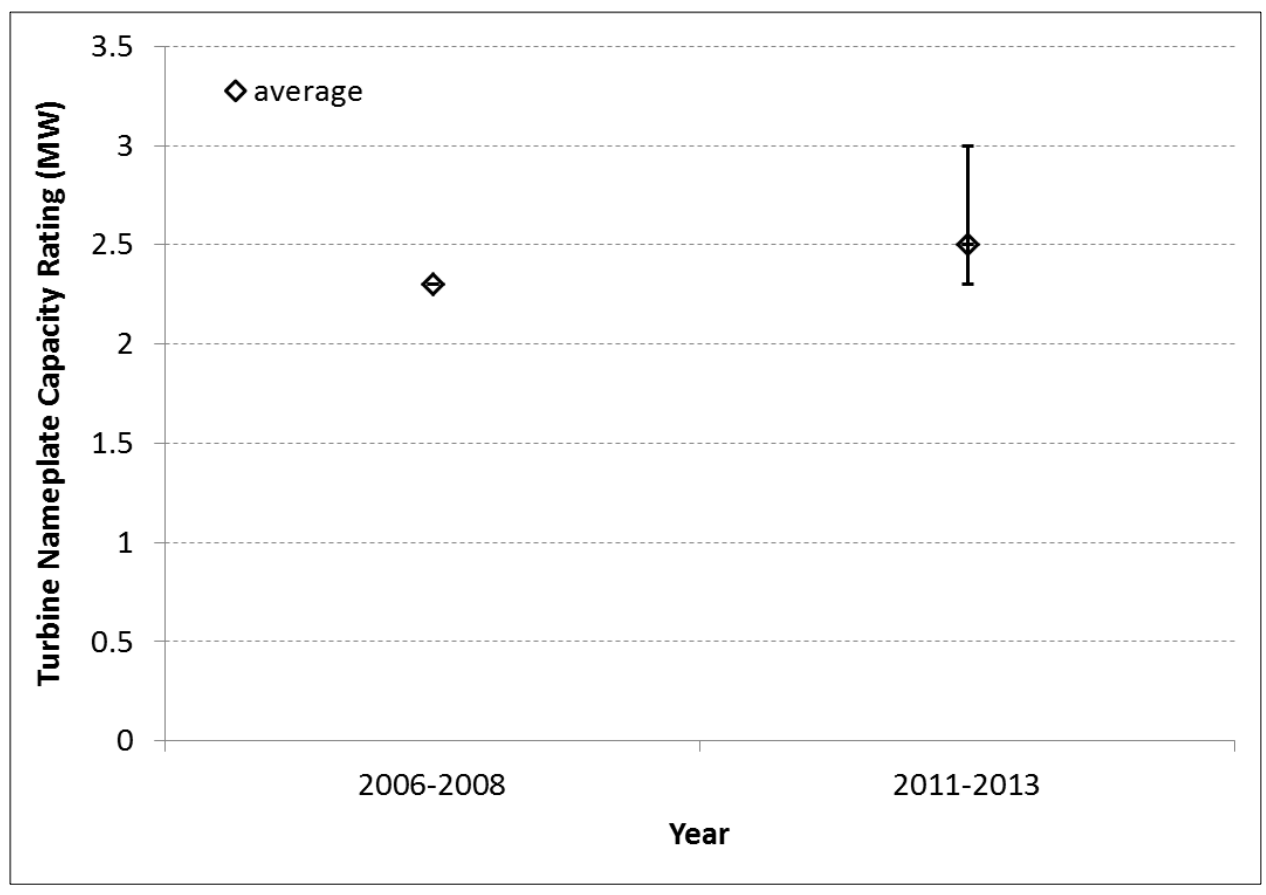

Figure 4-3. Wind turbine machine nameplate capacity trends from 2007 to 2012

Similarly, wind turbine hub heights and rotor diameters increased during the period 2007-2012. Rotor diameters in 2007 ranged from $71 \mathrm{~m}$ to $82 \mathrm{~m}$ with an average of $75 \mathrm{~m}$. In 2012 the range was 71-100 m with an average of $90 \mathrm{~m}$. Hub heights in 2007 ranged from 64 to $70 \mathrm{~m}$ while most of the turbines installed in $2012 \mathrm{had}$ a hub height of $80 \mathrm{~m}$. These trends are shown in figures 4-4 and 4-5 below. 
The general trend toward larger turbines, rotors, and nameplate capacities is consistent with international developments in wind turbine technology during this period, while the trend toward larger wind plant size in Figure 4-2 is sensitive to the number of projects in the Norwegian sample and the years chosen. Norway's largest wind plant (Smøla: $150 \mathrm{MW}$ ) was for example commissioned in 2002-2005. Despite the small sample a review of the projects which have received or applied for licenses in later years suggests that future wind power development in Norway will primarily be in the form of large wind plants (>50 MW). This can be attributed to the fact that Norway, unlike more densely populated countries, still has large uninhabited areas in areas with good wind resources.

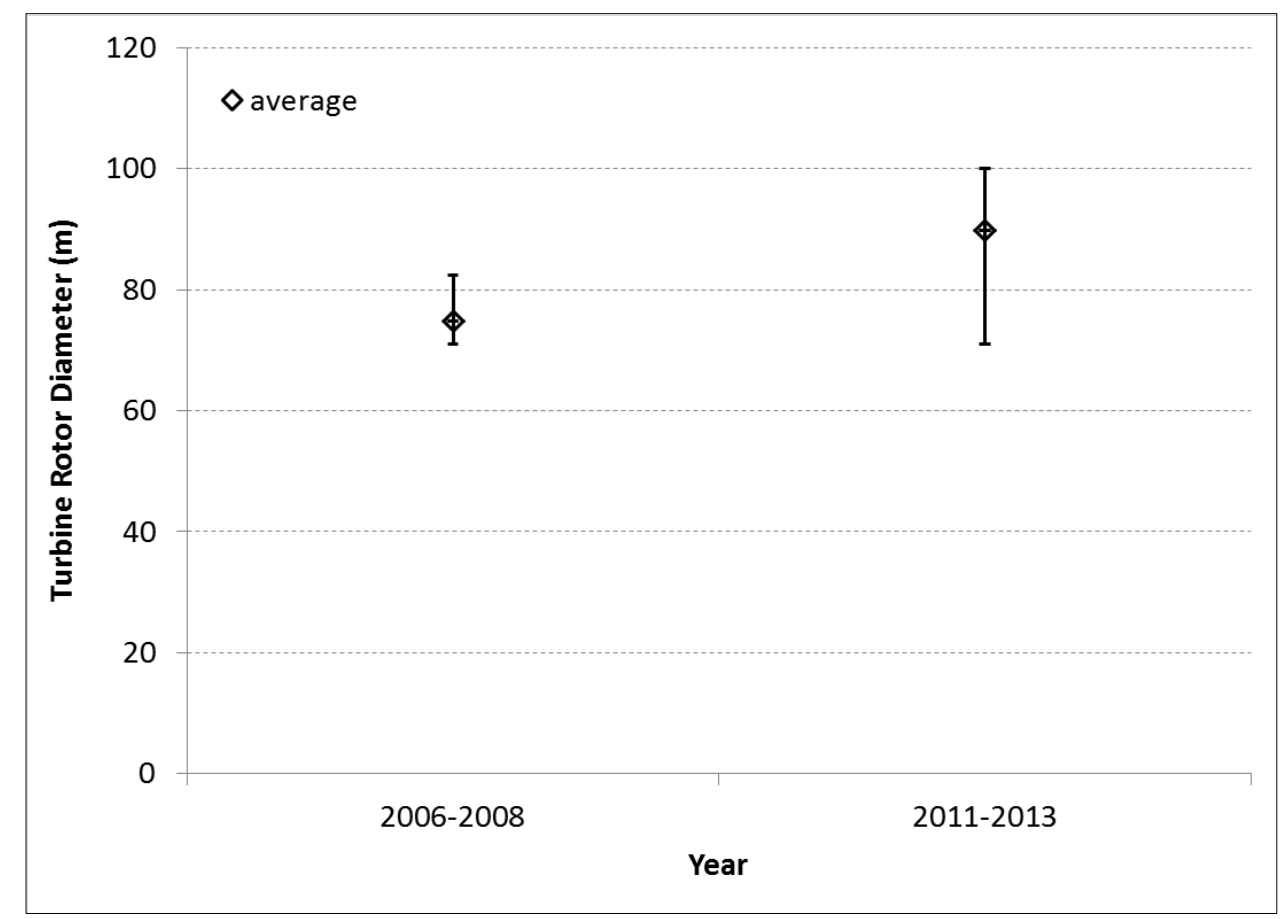

Figure 4-4. Wind turbine rotor diameter trends from 2007 to 2012

\section{Project Performance}

Norway has large areas with excellent wind resources, especially along the coast and on rounded mountaintops above the tree line (about half of Norway's land area is above the tree line). In the earlier years of wind power development in Norway there was much focus on sites with the highest wind speeds, which generally consist of coastal sites far from the larger population centers. Over the years the drawbacks of these types of sites (e.g., extreme wind and turbulence) have also become more understood.

While all of the wind plants commissioned in the period 2007-2012 can indeed be described as coastal/mountainous sites with excellent wind resources, there has been a trend toward sites with relatively lower average annual wind speed, which is shown in Figure 4-6 below. 


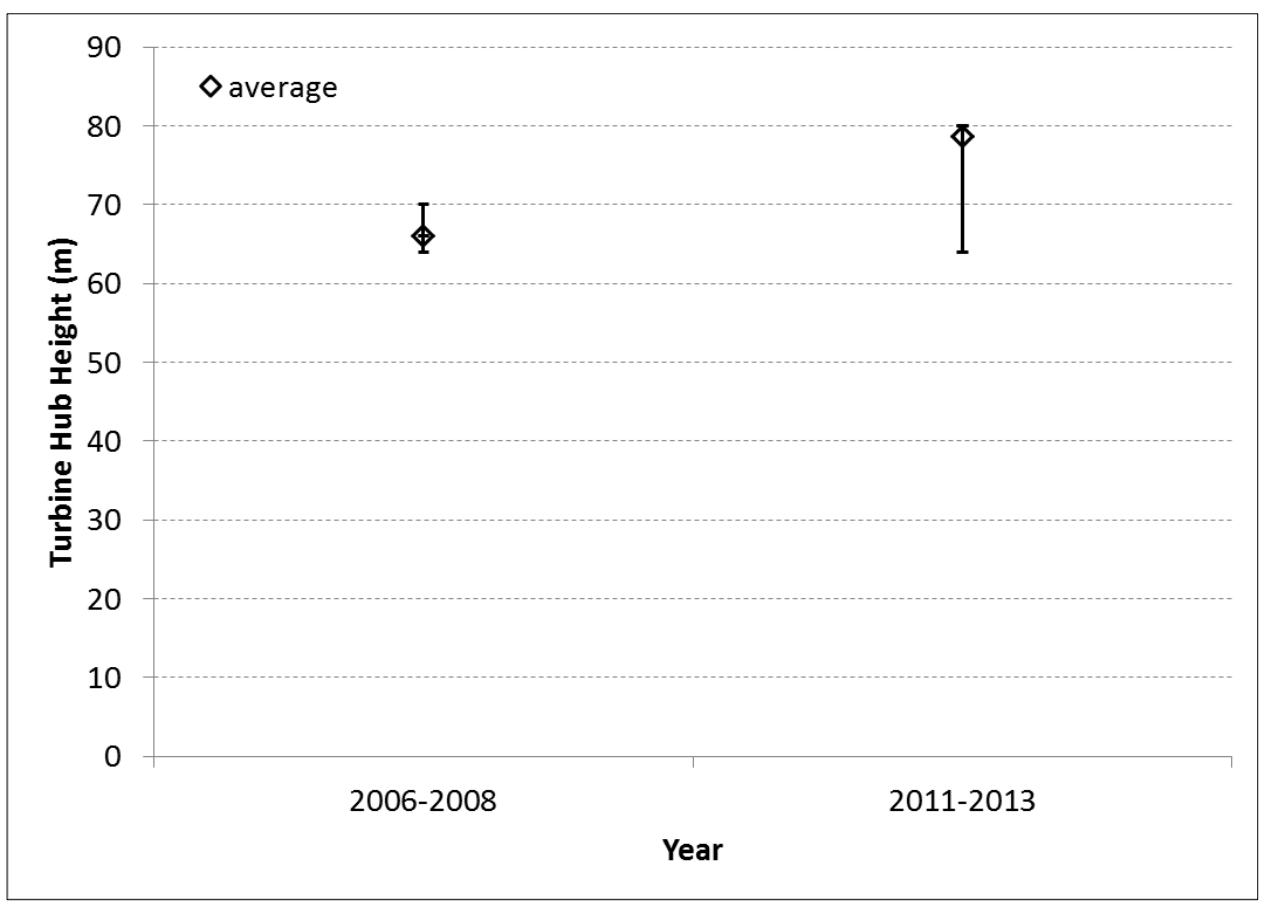

Figure 4-5. Wind turbine hub height trends from 2007 to 2012

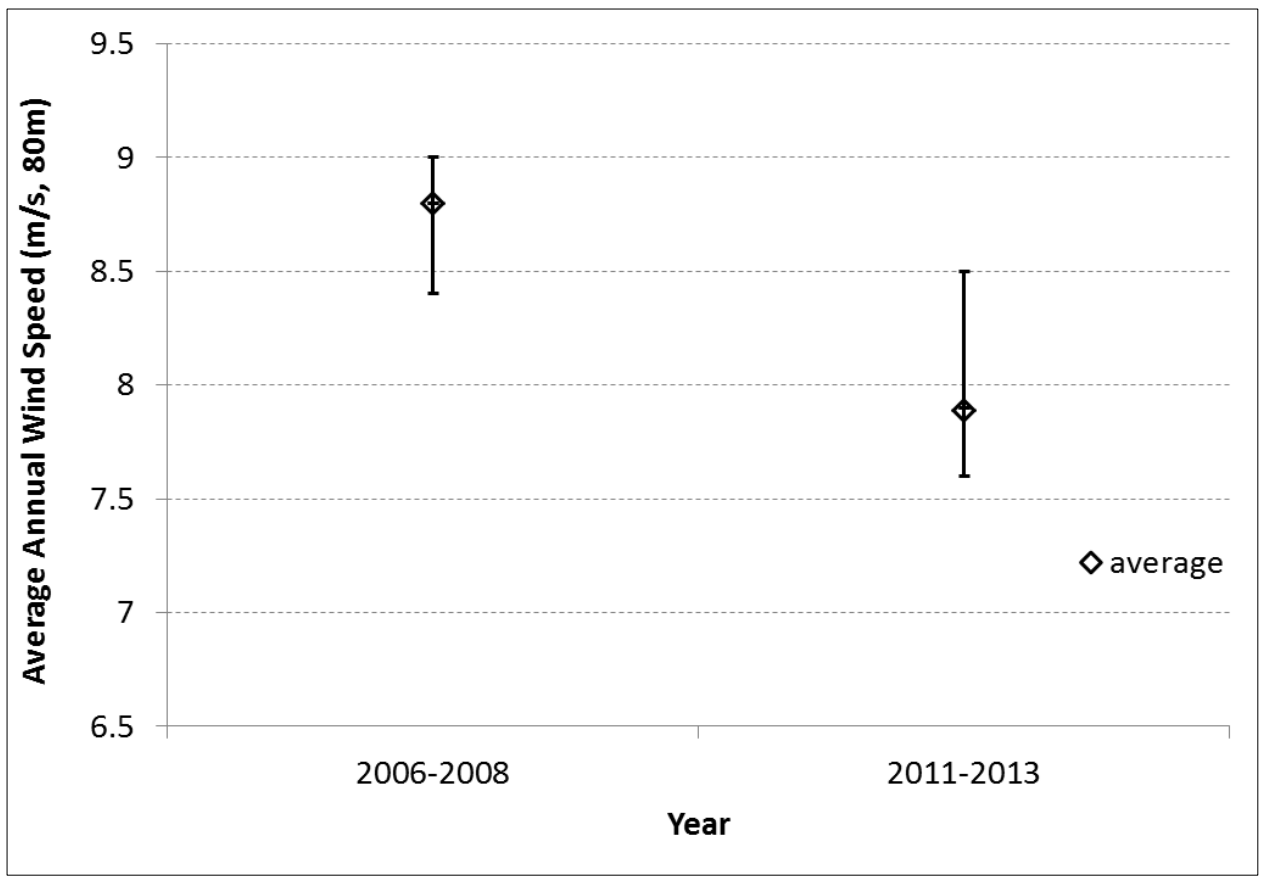

Figure 4-6. Annual average wind speed for projects installed from 2007 to 2012

In some countries this same trend toward sites with lower wind speeds has become apparent as sites with the best wind resources have already been developed, but this explanation does not hold in Norway. In Norway there are still many areas with very high annual average wind speeds which have not been developed, but in general the reason for this has been that the cost of 
connecting these projects to the grid is too high, or that the projects are on hold while grid upgrades take place, as has been the case in the Fosen region in central Norway.

In this same time period wind turbine technology has also improved more dramatically for wind turbines designed for low and medium wind speeds. The International Electro-Technical Commission (IEC) classification for a wind turbine is governed, in part, by the annual average wind speed for the turbine design. In Norway, there has been increased interest in sites which can accommodate IEC Class II or even III wind turbines despite the availability of Class I sites. Before 2012 all of the wind turbines in Norway were IEC Class I turbines due to high annual average wind speeds and/or extreme wind and turbulence. In 2012 however, around half of the turbines installed in Norway were IEC Class II (Figure 4-7).

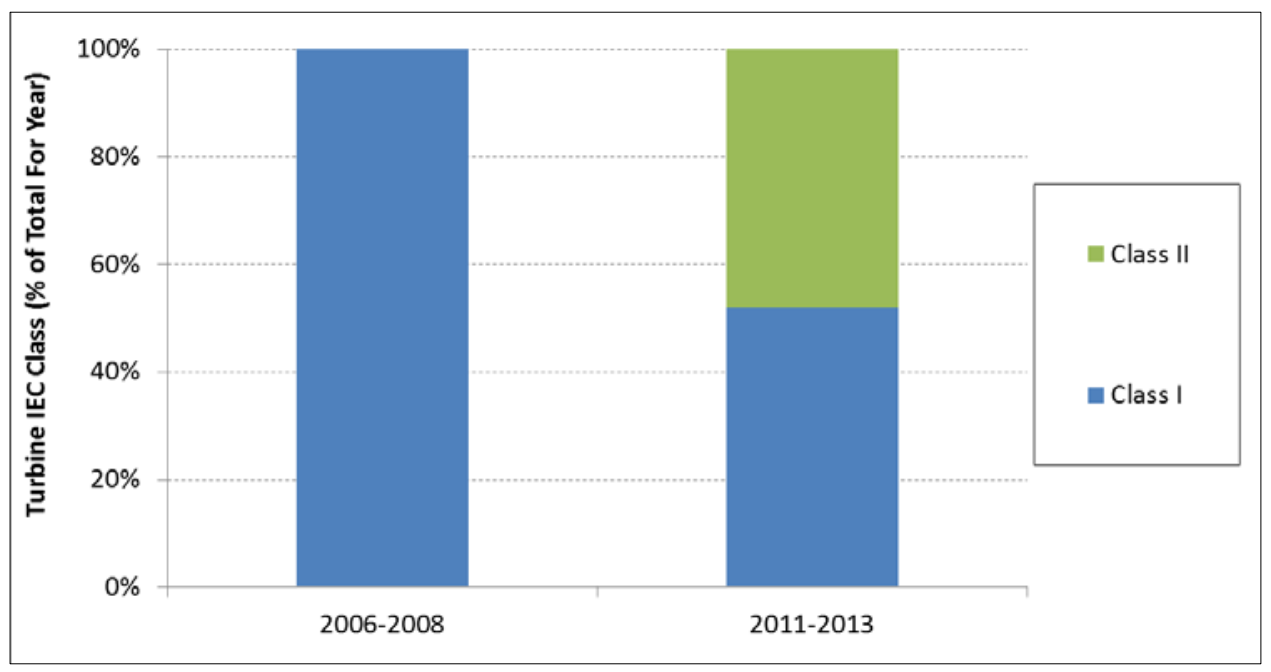

Figure 4-7. Wind turbine IEC classes, 2007-2012

In terms of production both the 2007 and 2012 plants have performed relatively well, with just under 3,000 full-load hours. Figure 4-8 below shows the minimum, maximum, and generationweighted mean for the two groups of wind plants. It is apparent from the figure that performance for the 2012 wind plants as a whole is slightly better than for 2007, and it is worth noting that both groups of wind plants perform well compared to the entire fleet of Norwegian wind plants, which had a generation weighted average of 2,555 full-load hours in 2013, which was a nearnormal wind year. For the wind plants in this study the full-load hours for a normal year were calculated by NVE based upon actual annual production data in the context of wind plant specific production indices. More information on these methods can be found in NVE's annual wind power production reports. ${ }^{45}$

\footnotetext{
${ }^{45} \mathrm{http}: / /$ www.nve.no/no/Energi1/Fornybar-energi/Vindkraft/Vindkraftproduksjon-2013/
} 


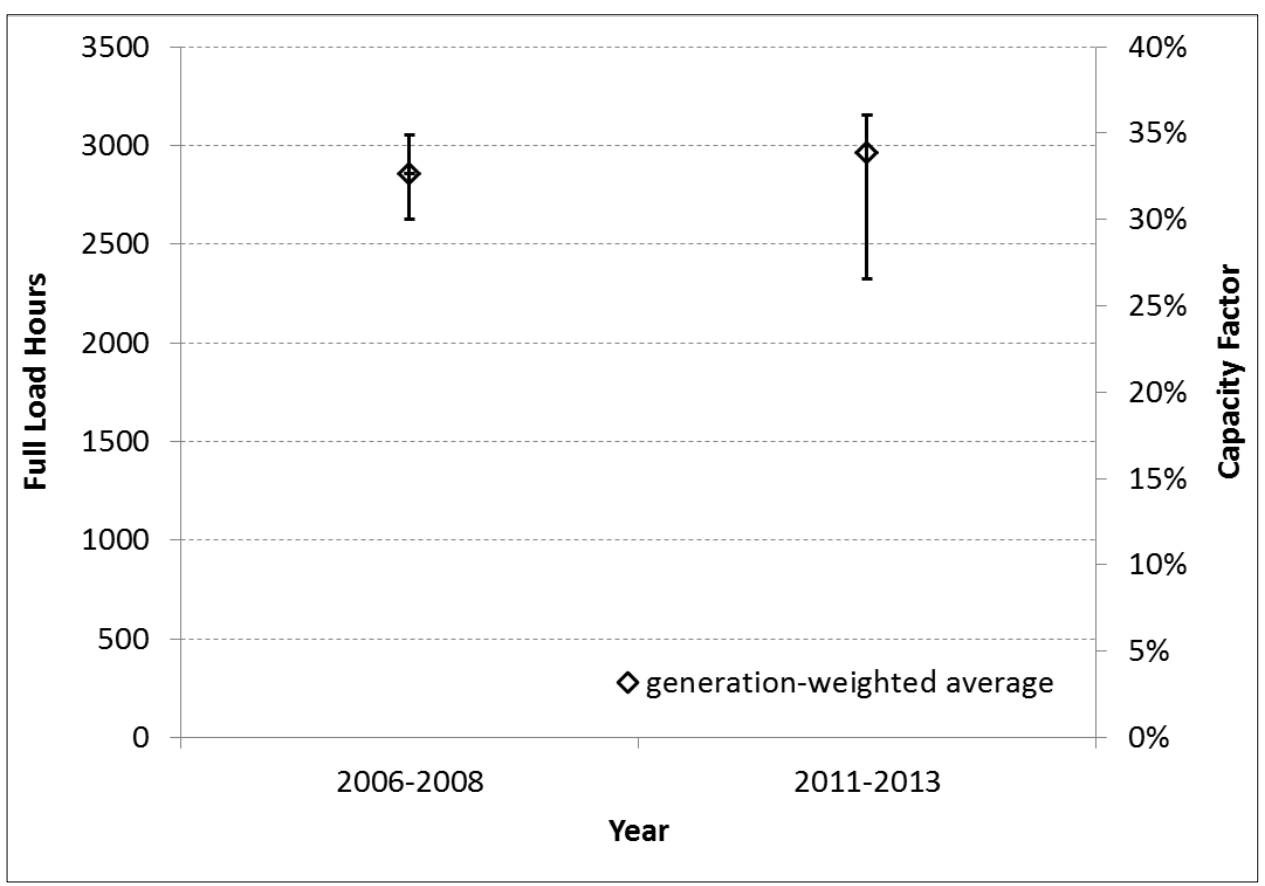

Figure 4-8. Full-load hours for projects installed from 2007 to 2011, operating in 2012

\section{Investment Costs}

NVE's data for investment costs consists of audited reports of final investment costs broken down into the following categories: wind turbines, foundations, internal grid, external grid connection, land acquisition, civil works, and project development. Due to laws concerning commercial secrets these costs have had to be aggregated to the degree at which they cannot be traced back to specific projects, but it is worth noting that each group of wind plants had considerable spread across nearly all of the components of CAPEX (capital expenditures, investment costs) including the total.

The average CAPEX for 2007 and 2012 wind plants is shown in Figure 4-9 below. From the figure it is evident that the average CAPEX actually increased considerably for Norwegian wind plants between 2007 and 2012, despite indications internationally that wind turbine prices went down during this period.

This increase in CAPEX from 2007 to 2012 is thought to be due, at least in part, to the subsidy mechanism which was in place during this period. Enova SF granted direct investment subsidies to wind plants in rounds, where only projects which were ripe for investment could apply in each round, and where the best projects for each round were awarded up to a certain percentage of their investment costs.

In practice this meant that competition among the projects in each round of funding was strongly influenced by how far projects had come in planning, and whether they could be built in the near term (many of the licensed projects have historically been on hold waiting for transmission line upgrades). In effect this meant that projects receiving Enova funding did not have to be exceptional projects in a national sense, but rather best in relation to the relatively few other 
projects applying for funding in the same round. Here it is important to emphasize the uncertainty associated with the small sample size used in this work.

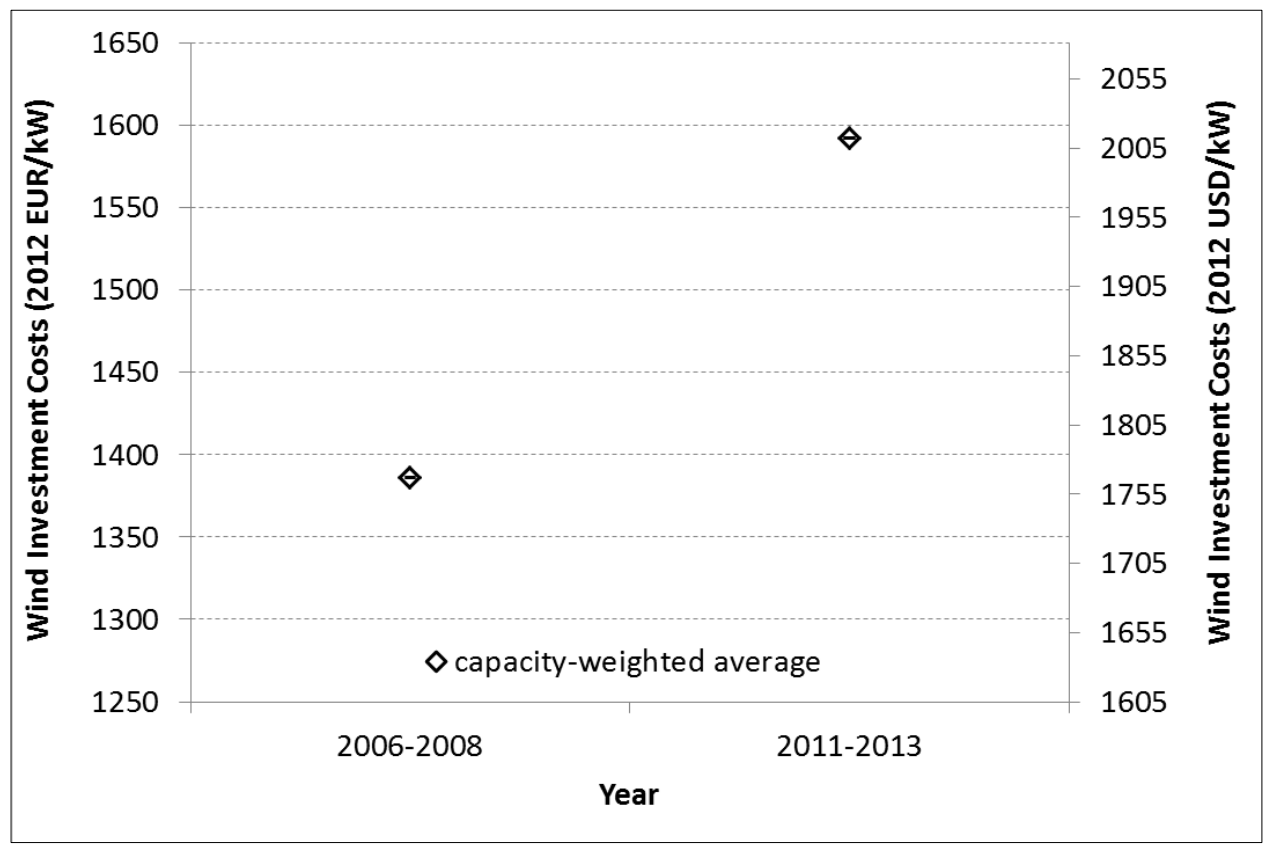

Figure 4-9. Investment costs for projects installed from 2007 to 2012

Another way that Enova's funding mechanisms can explain the increase in costs between 2007 and 2012 is that between 2008 and 2010 the direct investment subsidy was increased from 25\% of CAPEX to $50 \%$ of CAPEX, meaning that developers of the later projects did not have the same incentive to keep costs down across the board as the developers for the earlier projects. This is evident in the figures below, which show that especially costs for civil works and project management increased significantly in EUR/kW from 2007 to 2012.

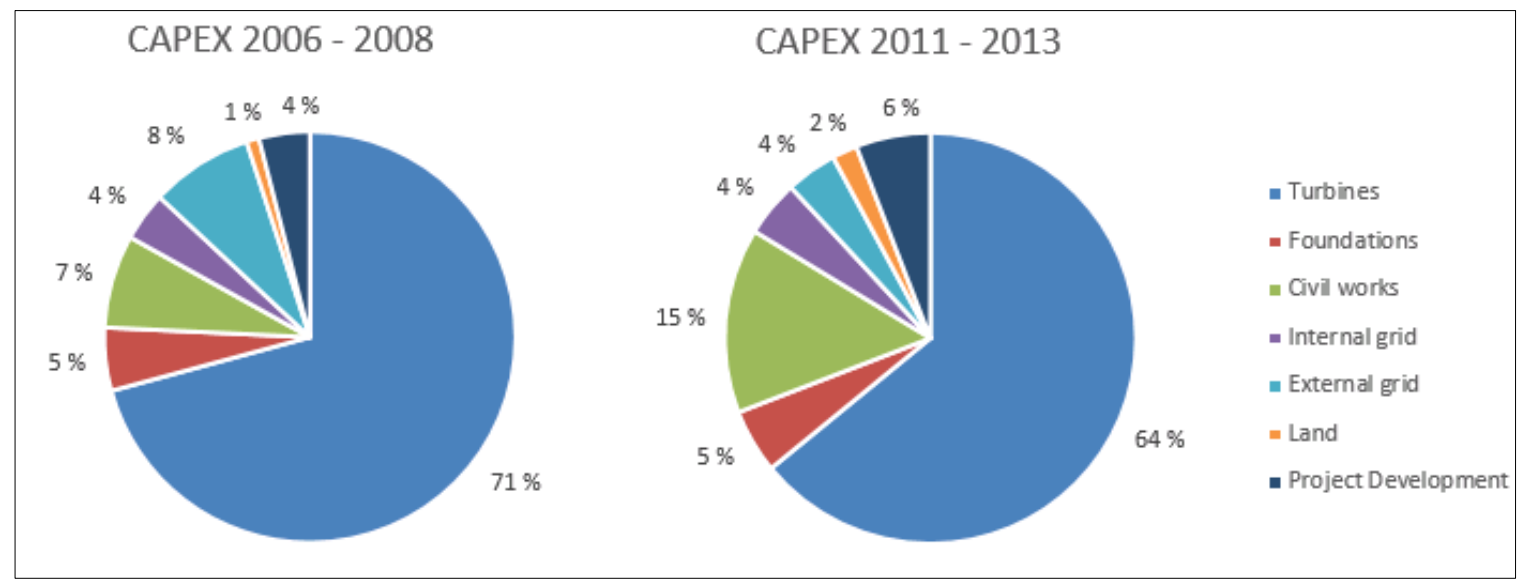

Figure 4-10. CAPEX breakdown, 2007-2012 


\section{Operations and Maintenance Costs}

Reliable project-specific data for operations and maintenance costs for Norwegian wind plants were not available for use in this study. The results of an industry survey conducted by NORWEA were used in which wind plant owners were asked to give representative costs for various O\&M costs. The results of the survey, as well as pre-construction estimates published by Enova $\mathrm{SF}^{46}$ indicate O\&M costs across the lifetime of a wind plant of around $€ 0.020 / \mathrm{kWh}$. An example of a relative breakdown of these costs is presented in figure 4-10 below. These results are based upon a survey conducted by the Norwegian Wind Energy Association (NORWEA), and indicate that the three largest contributions to O\&M costs are, in descending order, service agreements, grid access tariffs, and balancing costs.

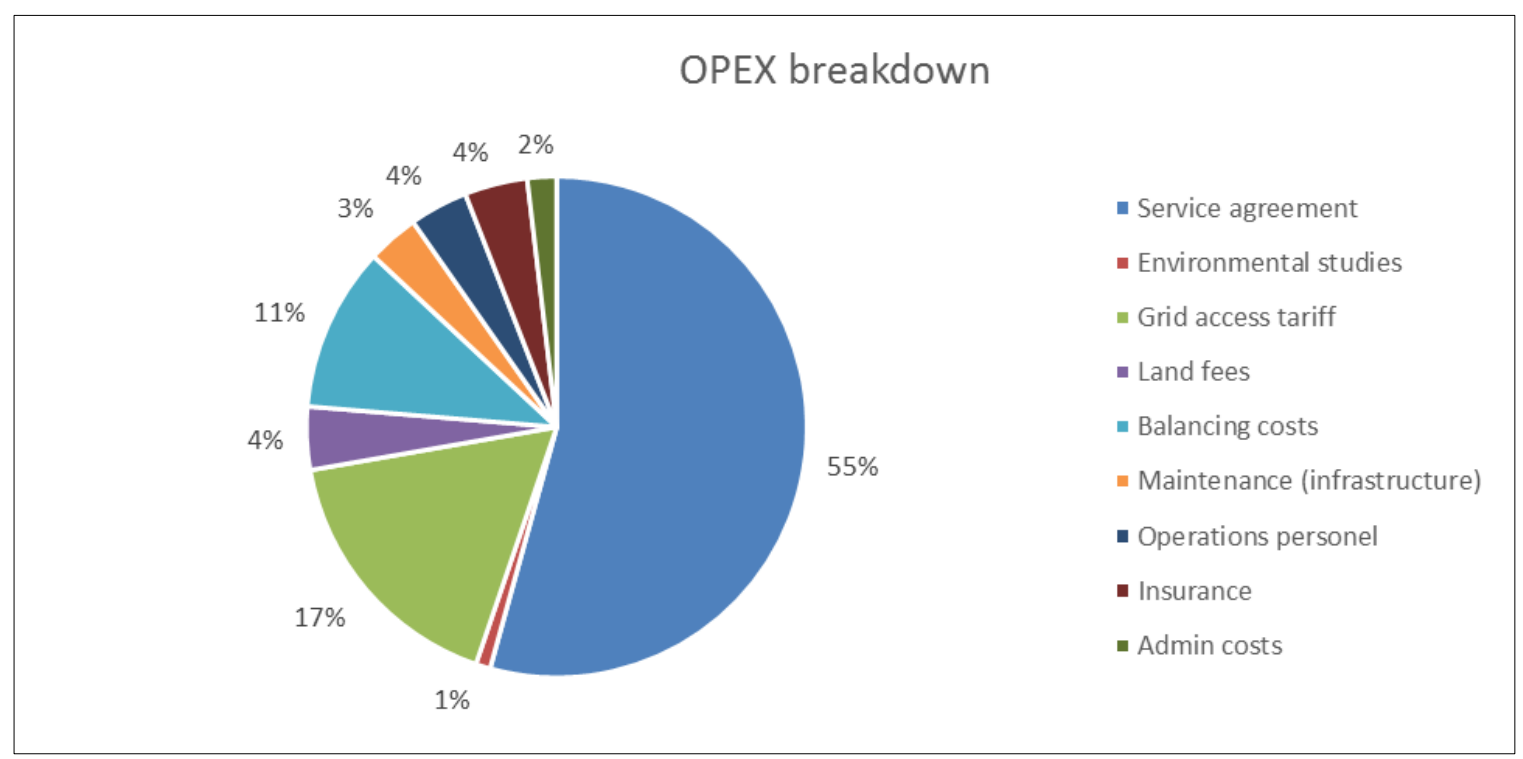

Figure 4-11. Estimated average breakdown of O\&M costs for projects installed from 2007 to 2012

\section{Financing Costs}

Project-specific data were not available for financing structures. These were instead estimated based upon limited data, a literature review, and general input from NORWEA and lending institutions.

Norwegian renewable projects have traditionally been owned and funded by Norwegian energy companies/utilities with access to considerable equity capital. Since 2009, low and falling prices of electricity (and electricity certificates from 2012) have limited profitability of renewable investments. Revenue streams from electricity and electricity certificate sales have proved to be highly uncertain. Combined with a growing Nordic power surplus, profitability expectations have been reduced, thus increasing the risk of investing in renewable projects. This is thought to have increased the risk premium, and thus the required return on equity, during the period 20072012. This has however been counteracted to varying degree as the risk-free interest rate has dropped considerably from 2007 to 2012 .

\footnotetext{
${ }^{46}$ http://www.enova.no/download.aspx?object_id=C2474F61250D4B9197B1A37F5786C036
} 
With sustained lower income, equity shares are thought to have been reduced from 2007 to 2012 . With lower profitability and poorer economic margins, future projects are expected to require new financing solutions, with greater customization and interaction between banking, export finance institutions, pension funds, and bond markets. For the modeling analysis, an assumption of $100 \%$ equity with required return on equity equivalent to the WACC is implemented.

For wind power plants built in 2007 and 2012 the WACC was assumed to be constant at 5\% (real terms, after tax). Long run inflation of $2.5 \%$ was assumed, given the Norwegian central banks operational target of monetary policy, with low and stable inflation of approximately $2.5 \%$ over time.

\section{Revenue and Policy Incentives}

From 2001 to 2010 financial support for wind power plants in Norway was provided by the stateowned organization Enova SF, on a case-by-case basis with the goal to support projects just enough to make them commercially viable. Plants built from 2006 to 2008 (Kjøllefjord, Valsneset, and Bessakerfjellet) received an upfront cash investment subsidy covering an average of approximately 25\% of their investment costs. For plants built from 2011 to 2013 (Høg-Jæren, Fakken, Ytre Vikna, Lista, and Midtfjellet) this support was increased to an average of approximately $50 \%$.

From 2012 onward Norwegian producers of new renewable electricity, including wind power, receive financial support through electricity certificates. To be eligible for certificates, project owners are not allowed to receive subsidies from other public programs. Owners of plants commissioned in 2012, which had earlier received Enova investment subsidies, were given the opportunity to refund the Enova subsidies and instead take part in the certificate scheme. None of the plant owners chose to do so in 2012, such that all of the 2012 projects presented in this chapter were financed through Enova.

Within the electricity certificate scheme, approved power plants receive one certificate for each megawatt hour (MWh) they produce, over a period of 15 years. Hence, owners of approved renewable energy plants have two products on the market: electricity and certificates. They can be sold independently of each other and both revenue streams are highly uncertain. From 20122014 Norwegian producers entitled to certificates received an average of approximately $€ 20 / \mathrm{MWh}$ produced (based on the average spot price of certificates). The system is technology neutral; all renewable technologies receive the same number of certificates per MWh, and there are no specific quotas for wind power. However, to achieve the goal of 26.4 TWh new renewable production in Norway and Sweden it is assumed that a large amount of new wind power must be realized, due to the limited availability of cheaper forms of renewable production. This is expected to have a driving effect on the price of electricity certificates, where the combination of income from power and certificate sales on the longer term should offset the LCOE of wind power.

The demand for certificates is created by a requirement under the act that all electricity users purchase certificates equivalent to a certain proportion of their electricity use, known as their quota obligation. For 2012, Norwegian market participants with quota obligations had to purchase electricity certificates corresponding to $3 \%$ of their calculation-relevant electricity 
consumption. The quotas gradually increase until 2020, which causes increasing demand for electricity certificates.

\section{Cost of Wind Energy Generation in Norway in 2008 and 2012}

\section{Representative Wind Energy Project in 2008 and 2012}

To represent LCOE for wind energy in Norway for 2008 and 2012 capacity-weighted averages of the investment costs in each sample were used. In addition a theoretical reference project for 2014 is presented.

\section{Model Input Assumptions}

Table 4-2. Wind Energy Project Features in Norway

\begin{tabular}{|l|l|r|r|r|}
\hline & & 2008 & 2012 & $2014^{*}$ \\
\hline Unit size & MW & 2.3 & 2.5 & 3.0 \\
\hline Number of turbines & $\mathrm{N}$ & 17 & 24 & 30 \\
\hline Rotor Diameter / hub height & $\mathrm{m} / \mathrm{m}$ & $75 / 66$ & $93 / 79$ & $100 / 80$ \\
\hline Annual average wind speed at hub height & $\mathrm{m} / \mathrm{s}$ & 8.8 & 7.9 & 8.0 \\
\hline Production & $($ full-load hours) & 2,860 & 2,963 & 3,200 \\
\hline Economic life & (years) & 20 & 20 & 20 \\
\hline Investment costs & $(€ 2012 / \mathrm{kW})$ & 1,386 & 1,592 & 1,359 \\
\hline O\&M costs fixed & $(€ / \mathrm{kW})$ & $\mathrm{N} / \mathrm{A}$ & $\mathrm{N} / \mathrm{A}$ & $\mathrm{N} / \mathrm{A}$ \\
\hline O\&M costs variable & $(€ c t / \mathrm{kWh})$ & 2 & 2 & 2 \\
\hline Decommission costs & $(€ c t / \mathrm{kWh})$ & 0 & 0 & 0 \\
\hline
\end{tabular}

* Theoretical reference project for 2014

Table 4-3. Wind Energy Financing Terms in Norway

\begin{tabular}{|l|l|c|c|c|}
\hline & & 2008 & 2012 & $2014^{*}$ \\
\hline Return on equity & $\%$ & N/A & N/A & N/A \\
\hline Return on debt & $\%$ & N/A & N/A & N/A \\
\hline Equity share & $\%$ & 100 & 100 & 100 \\
\hline Debt share & $\%$ & N/A & N/A & N/A \\
\hline Loan duration & (years) & 20 & 20 & 20 \\
\hline Corporate tax rate & $\%$ & 28 & 28 & $27^{\text {** }}$ \\
\hline WACC (real, after tax) & $\%$ & 5 & 5 & 5 \\
\hline FX rate & (NOK/€) & 8.2 & 7.5 & 8.4 \\
\hline
\end{tabular}

* Theoretical reference project for 2014

** Corporate tax rate was lowered from $28 \%$ to $27 \%$ in 2014 . 
Table 4-4. Wind Energy Policy and Revenue Incentives in Norway

\begin{tabular}{|l|l|c|c|c|}
\hline & & 2008 & 2012 & $2014^{*}$ \\
\hline Market price electricity & $€ / \mathrm{kWh}$ & 0.061 & 0.041 & 0.031 \\
\hline Upfront investment & & & & \\
\hline \multicolumn{1}{|c|}{ subsidy before tax } & $\%$ & 25 & 50 & 0 \\
\hline Depreciation period & (years) & 20 & 20 & $20^{* * *}$ \\
\hline Market Certificates & $€ / \mathrm{kWh}$ & $\mathrm{N} / \mathrm{A}$ & $\mathrm{N} / \mathrm{A}$ & 0.016 \\
\hline
\end{tabular}

* Theoretical reference project for 2014

** From 2015, the Norwegian government has proposed to reduce the depreciation period to 5 years. This is not taken into account here.

\section{Financial Gap}

Calculations in the ECN model with the above assumptions yield an LCOE of $€ 65 / \mathrm{MWh}$ for 2008 , increasing to $€ 70 / \mathrm{MWh}$ in 2012 . For a theoretical 2014 reference project the LCOE is estimated at $€ 59 / \mathrm{MWh}$. To consider financial gap in the same period power prices and upfront cash subsidies were included as follows:

Market power prices are calculated from NASDAQ futures (one- to five-year forward contracts traded at NordPool in 2008, 2012, and 2014) converted to $2012 €$. Prices fell significantly in the period analyzed. As the Nordic price of electricity is highly uncertain and volatile, prices presented in Table 4-5 only represent a central base case of prices developers faced in 2008, 2012, and 2014, although they do capture this drop in prices between 2008, 2012, and 2014.

The $€ / M W h$ equivalent of the upfront cash subsidies is also calculated in the ECN model assuming upfront cash subsidies of $25 \%$ and 50\% of the CAPEX for 2008 and 2012 respectively. For the 2014 reference project the electricity certificate support is assumed to be approximately $€ 21 / \mathrm{MWh}$, granted over a period of 15 years, based on one- to five-year forward contracts traded at SKM kraftmäkling. This represents an average policy impact of approximately $€ 16 / \mathrm{MWh}$ over the project lifetime of 20 years. An overview of all of these base case assumptions and their resulting financial gap is shown in Figure 4-12 below. As the figure demonstrates, the increases in the cash subsidies for the later projects were counteracted by falling power prices meaning that with these base assumptions the projects in 2008 present as profitable, with financial gap of $€-7 / \mathrm{MWh}$, while the projects in the 2012 period on average appear to have a positive financial gap of $€ 4 / \mathrm{MWh}$. The 2014 project has a financial gap of $€ 12 / \mathrm{MWh}$ under these assumptions.

While the financial gaps calculated and presented in Figure 4-12 are informative, it is important to emphasize the uncertainty in such calculations, which stems largely from the uncertainty of market prices of electricity over the lifetime of the wind plants. Figure 4-13 illustrates the sensitivity of the financial gap for 2008, 2012, and 2014 projects to the average market prices of electricity over the lifetime of the wind plants. As shown in the figure, the 2012 group of projects become profitable with a long term revenue from power sales around $€ 45 / \mathrm{MWh}$, while the 2008 projects, despite lower LCOE, require almost $€ 10 / \mathrm{MWh}$ higher prices due to their lower upfront investment subsidy ( $25 \%$ versus $50 \%$ for 2012 projects). The 2014 - reference project is profitable at an electricity price of $43 \mathrm{EUR} / \mathrm{MWh}$, assuming an average income of $€ 16 / \mathrm{MWh}$ stemming from electricity certificate revenues. For the 2014-project the market price of certificates introduces an additional moment of uncertainty, which is not shown in Figure 4-13. 


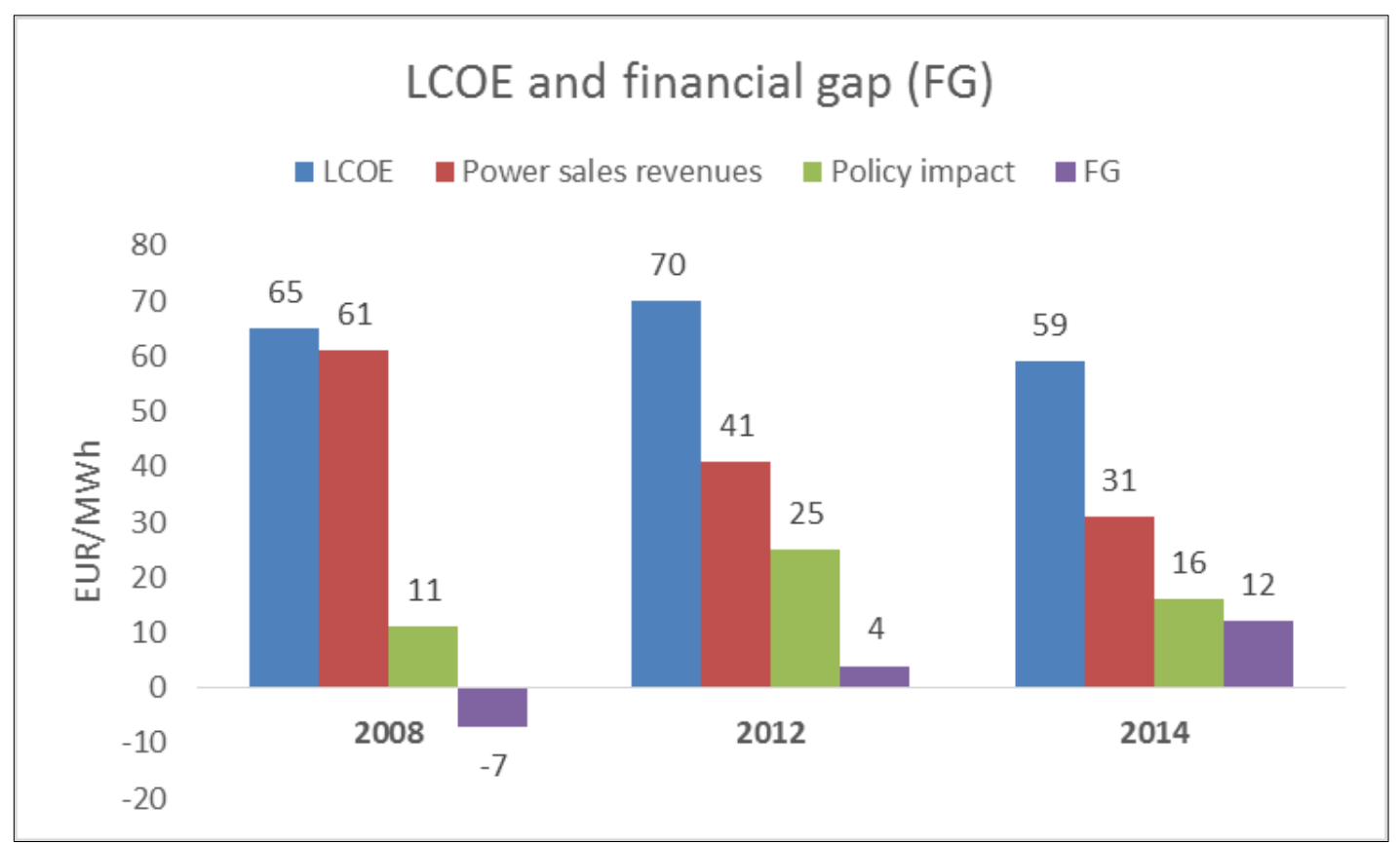

Figure 4-12. Wind energy revenue and policy incentives in Norway in 2008, 2012, and 2014

The Norwegian government has proposed more favorable depreciation rules from 2015 onward, reducing the depreciation period from 20 to five years, and at the same time changing the depreciation method from a declining balance method to linear method. Calculated in the ECN model, this lowers the LCOE with approximately $€ 3 / \mathrm{MWh}$, contributing to a lower LCOE for Norwegian wind projects. This is however not taken into account here.

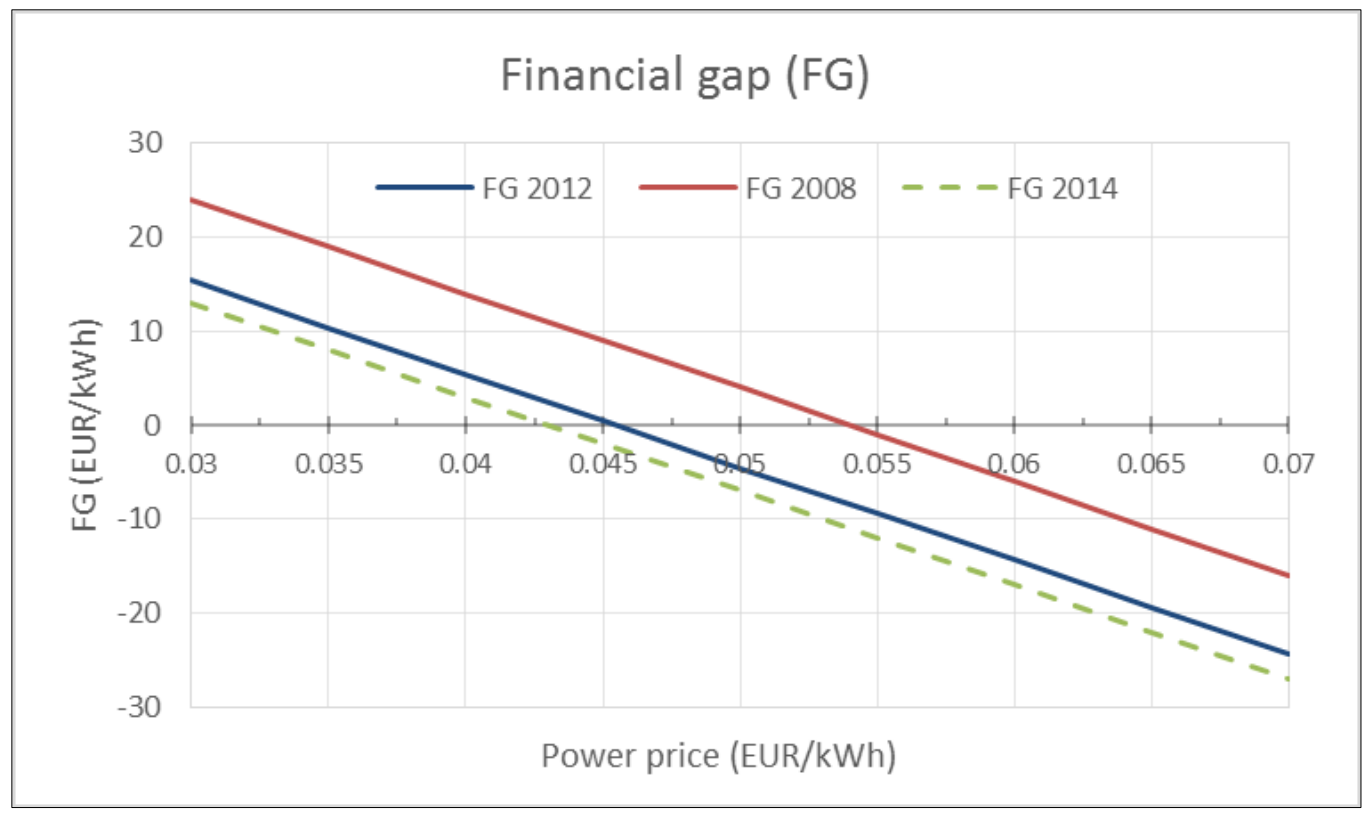

Note: FG varies with power price.

Figure 4-13. FG sensitivity analysis for 2008 and 2012 projects, and a 2014 reference project 


\section{Summary of Wind Projects in Norway}

Between 2007 and 2012, CAPEX increased for wind power plants in Norway from $€ 1,386 / \mathrm{kW}$ to $1,592 / \mathrm{kW}$. At the same time average production increased slightly from 2,860 to 2,963 full-load hours per year. The significant increases in CAPEX were not outweighed by the marginal increases in production, and the result was an increase in LCOE from $€ 65 / \mathrm{MWh}$ to $€ 70 / \mathrm{MWh}$ during this period.

The increase in LCOE from 2007 to 2012 was somewhat offset from an investor perspective by more than a doubling in the up-front cash subsidies for the later projects, but a relatively drastic fall in power prices over the period has meant that the 2008 projects as a whole appear more profitable than 2012 projects.

The theoretical reference project for 2014 is estimated to have a LCOE of $€ 59 / \mathrm{MWh}$, and has both lower investment costs and higher production than the 2012 projects. With the new electricity certificate scheme in place, the cost of future projects is expected to be reduced compared to 2012, as competition increases and only the most profitable projects are to be realized in the Norwegian-Swedish market. This cost reduction is reflected in the significant LCOE reduction for the 2014 reference project, but with the available prognoses of power and certificate prices in 2014 , this project still has a significantly positive financial gap. Price expectations vary over time, and this is demonstrated in the differences in power price expectations for the different years in this study. Since the profitability of Norwegian projects for all years presented here is very sensitive to long term power sales revenues, this translates to a high uncertainty in calculations of financial gap from assumptions in a single year. The average forward prices from a single year can for example be driven by short term factors such as hydrology and temperature. Producers may hedge revenues with PPAs over the longer term, but wind power specific data for PPAs was not available.

In the long run, the sum of electricity and electricity certificate revenues is expected to offset the LCOE of new Norwegian and Swedish wind power projects. This is due to the market-based nature of the electricity certificate scheme, and more specifically its implicit dependence on wind power to achieve the set goal of new renewable production.

Table 4-5. LCOE, Revenue and Policy Incentives, and Financial Gap for 2008 and 2012

\begin{tabular}{|l|l|r|r|r|}
\hline & & 2008 & 2012 & $2014^{*}$ \\
\hline Levelized cost of energy & $(€ c t / k W h)$ & 65 & 70 & 59 \\
\hline Revenue and policy incentives & $(€ c t / k W h)$ & 72 & 66 & 47 \\
\hline Financial gap for developer & $(€ c t / k W h)$ & -7 & 4 & 12 \\
\hline
\end{tabular}

\footnotetext{
* Theoretical reference project for 2014
} 


\section{Appendix 4-A Sample Size and Project Data for Norway}

This appendix contains statistics representing wind project characteristics that are illustrated in the chapter. Table 4-6 describes the sample size of data represented in the subsequent tables. The values in the table correspond to the installed wind project capacity in a given year, or the percentage of annual installed capacity, that is included in the database. For example, an entry of $100 \%$ for Wind Turbine Hub Height means that the statistics shown in the corresponding table and figure for hub height represent $100 \%$ of the turbines installed in that year. 
Table 4-6. Definitions and Sample Size for Norway

\section{COUNTRY: NORWAY}

\section{DEFINITION OF UTILITY SCALE WIND}

All land-based wind projects equal to or over $1 \mathrm{MW}$ in size; with all turbines in the project also equal to or over $1 \mathrm{MW}$; and only including projects that sell electricity to the grid (e.g., project size YEAR DATA AGGREGATION

Due to small number of projects the data have been aggregated across several years. Three projects built in 2006-2008 are used to OTHER NOTES

\begin{tabular}{|l|cr|}
\hline SAMPLE & Capacity (Megwatts) \\
\cline { 2 - 3 } & $2006-2008$ & $2011-2013$ \\
\hline Annual Installations -- Land-Based, Utility-Scale Only \\
$\quad$ Total Wind Power Additions \\
Sample Size -- Land-Based, Utility-Scale Only & 145 & 373 \\
Wind Project Size & 108 & 348 \\
Wind Turbine Nameplate Capacity Rating & 108 & 348 \\
Wind Turbine Rotor Diameter & 108 & 348 \\
Wind Turbine Hub Height & 108 & 348 \\
Wind Turbine Specific Power & 108 & 348 \\
Wind Turbine IEC Class & 108 & 348 \\
Annual Average Wind Speed & 108 & 348 \\
Full Load Hours (generation in 2012) & 108 & 348 \\
Investment Costs & 108 & 348 \\
Operations and Maintenance Costs & $n a$ & na \\
Financing Costs & $n a$ & na \\
Sample Size (\%) -- Land-Based, Utility-Scale Only & & \\
Wind Project Size & $74 \%$ & $93 \%$ \\
Wind Turbine Nameplate Capacity Rating & $74 \%$ & $93 \%$ \\
Wind Turbine Rotor Diameter & $74 \%$ & $93 \%$ \\
Wind Turbine Hub Height & $74 \%$ & $93 \%$ \\
Wind Turbine Specific Power & $74 \%$ & $93 \%$ \\
Wind Turbine IEC Class & $74 \%$ & $93 \%$ \\
Annual Average Wind Speed & $74 \%$ & $93 \%$ \\
Full Load Hours (generation in 2012/2013) & $74 \%$ & $93 \%$ \\
Investment Costs & $74 \%$ & $93 \%$ \\
Operations and Maintenance Costs & $0 \%$ & $0 \%$ \\
Financing Costs & $0 \%$ & $0 \%$ \\
\hline
\end{tabular}


Table 4-7. Wind Turbine Project Size Statistics

\begin{tabular}{|l|r|r|} 
Wind Project Size (MW) \\
\hline & 2006-2008 & 2011-2013 \\
\hline $\mathrm{n}$ (\# projects) & & \\
\hline median & 36.0 & 62.2 \\
\hline 25th percentile & 36.0 & 62.2 \\
\hline 75th percentile & 36.0 & 62.2 \\
\hline minimum & 11.5 & 39.1 \\
\hline maximum & 57.5 & 110.0 \\
\hline average & 36.0 & 62.2 \\
\hline
\end{tabular}

Table 4-8. Wind Turbine Nameplate Capacity Rating Statistics

\begin{tabular}{|l|r|r|}
\hline \multicolumn{3}{|c|}{ Wind Turbine Nameplate Capacity Rating (MW) } \\
\hline & 2006-2008 & 2011-2013 \\
\hline $\mathrm{n}$ (\# turbines) & 47 & 153 \\
\hline median & 2.3 & 2.5 \\
\hline 25th percentile & 2.3 & 2.5 \\
\hline 75th percentile & 2.3 & 2.5 \\
\hline minimum & 2.3 & 2.3 \\
\hline maximum & 2.3 & 3 \\
\hline average & 2.3 & 2.5 \\
\hline
\end{tabular}

Table 4-9. Wind Turbine Rotor Diameter Statistics

\begin{tabular}{|l|r|r|} 
Wind Turbine Rotor Diameter $(\mathbf{m})$ \\
\hline & 2006-2008 & 2011-2013 \\
\hline $\mathrm{n}$ (\# turbines) & & \\
\hline median & 74.8 & 89.7 \\
\hline 25th percentile & 74.8 & 89.7 \\
\hline 75th percentile & 74.8 & 89.7 \\
\hline minimum & 71 & 71 \\
\hline maximum & 82.4 & 100 \\
\hline average & 74.8 & 89.7 \\
\hline
\end{tabular}


Table 4-10. Wind Turbine Hub Height Statistics

\begin{tabular}{|l|r|r|} 
Wind Turbine Hub Height (m) \\
\hline & 2006-2008 & 2011-2013 \\
\hline $\mathrm{n}$ (\# turbines) & & \\
\hline median & 66 & 80 \\
\hline 25th percentile & 66 & 80 \\
\hline 75th percentile & 66 & 80 \\
\hline minimum & 64 & 64 \\
\hline maximum & 70 & 80 \\
\hline average & 66.0 & 78.6 \\
\hline
\end{tabular}

Table 4-11. Average Annual Wind Speed Statistics

\begin{tabular}{|c|c|c|}
\hline \multicolumn{3}{|c|}{$\begin{array}{l}\text { Average Annual Wind } \\
\text { Speed }\end{array}$} \\
\hline & $\begin{array}{r}2006- \\
2008\end{array}$ & $\begin{array}{r}2011 \\
2013\end{array}$ \\
\hline \multicolumn{3}{|l|}{ n (\# turbines) } \\
\hline median & N/A & $\mathrm{N} / \mathrm{A}$ \\
\hline 25th percentile & N/A & $\mathrm{N} / \mathrm{A}$ \\
\hline 75th percentile & $\mathrm{N} / \mathrm{A}$ & $\mathrm{N} / \mathrm{A}$ \\
\hline minimum & 8.4 & 7.6 \\
\hline maximum & 9 & 8.5 \\
\hline average & 8.8 & 7.9 \\
\hline
\end{tabular}

Table 4-12. Wind Turbine IEC Class Statistics

\begin{tabular}{|l|r|r|}
\hline \multicolumn{3}{|c|}{ Wind Turbine IEC Class - Average Class } \\
\hline & $2006-2008$ & $2011-2013$ \\
\hline Class I & $100 \%$ & $52 \%$ \\
\hline Class I/II & & \\
\hline Class II & & $48 \%$ \\
\hline Class II/III & & \\
\hline Class III & & \\
\hline Average & 1.0 & 1.5 \\
\hline n (\# turbines) & & \\
\hline
\end{tabular}


Table 4-13. Full Load Hours Statistics

Full Load Hours in 2012 (equivalent to capacity factor *

8784)

\begin{tabular}{|l|r|r|}
\hline & \multicolumn{1}{|l|}{$\begin{array}{l}\text { 2006- } \\
\text { Project COD }\end{array}$} & \multicolumn{2}{l|}{\begin{tabular}{l}
\multicolumn{1}{l|}{ 2011- } \\
median
\end{tabular}} & N/A & N/A \\
\hline 25th percentile & N/A & N/A \\
\hline 75th percentile & 2626 & N/A \\
\hline minimum & 3053 & 3156 \\
\hline maximum & 2860.2 & 2963 \\
\hline generation-weighted average & \multicolumn{2}{|l}{} \\
\hline
\end{tabular}

Table 4-14. Investment Costs Statistics

Wind Project Investment Costs (2012 EUR per
kW)
\begin{tabular}{|l|r|r|}
\hline & $\begin{array}{l}\text { 2006- } \\
2008\end{array}$ & $\begin{array}{l}\text { 2011- } \\
2013\end{array}$ \\
\hline median & N/A & N/A \\
\hline 25th percentile & N/A & N/A \\
\hline 75th percentile & 1386 & N/A \\
\hline minimum & 1386 & 1592 \\
\hline maximum & 1386 & 1592 \\
\hline $\begin{array}{l}\text { capacity-weighted } \\
\text { average }\end{array}$
\end{tabular}

Wind Project Investment Costs (2012 USD per
kW)
\begin{tabular}{|l|r|r|}
\hline & $\begin{array}{l}\text { 2006- } \\
2008\end{array}$ & $\begin{array}{l}2011- \\
2013\end{array}$ \\
\hline median & N/A & N/A \\
\hline 25th percentile & N/A & N/A \\
\hline 75th percentile & 1780.8 & N/A \\
\hline minimum & 1780.8 & 2045.5 \\
\hline maximum & 1780.8 & 2045.5 \\
\hline $\begin{array}{l}\text { capacity-weighted } \\
\text { average }\end{array}$
\end{tabular}




\section{Chapter 5. Wind Energy Development in the European Union}

Authors: Roberto Lacal-Arántegui. Scientific Officer, Institute for Energy and Transport, Joint Research Centre, European Commission

This chapter should be cited as: Lacal-Arantegui, R. (2015). "Wind Energy Development in the European Union," Chapter 5. Hand, M. M., ed., IEA Wind Task 26 - Wind Technology, Cost, and Performance Trends in Denmark, Germany, Ireland, Norway, the European Union, and the United States: 2007-2012. NREL/TP-6A20-64332. Golden, CO: National Renewable Energy Laboratory. pp. 121-136.

This chapter describes the development of wind energy in an aggregated way for 26 of the 28 European Union (EU) Member States (MS): Austria, Belgium, Bulgaria, Croatia, Cyprus, Czech Republic, Denmark, Estonia, Finland, France, Germany, Greece, Hungary, Ireland, Italy, Latvia, Lithuania, Luxemburg, the Netherlands, Poland, Portugal, Romania, Slovakia, Spain, Sweden, and the United Kingdom (UK). Croatia, a recent EU member, is included even when it was not an EU MS during the period under analysis. In addition, two MS (Malta and Slovenia) are not included as they did not have any wind power installed capacity during the period.

\section{Domestic Wind Energy Capacity, Production, and Targets}

The years 2008-2012 saw a significant addition to the cumulative capacity installed in the European Union (EU) as this doubled from $56.5 \mathrm{GW}$ at the end of 2007 to $106 \mathrm{GW}$ at the end of 2012. Figure 5-1 shows land-based and offshore cumulative and annual capacity installations, as well as projections by the $\mathrm{JRC}^{47}$ to 2015 and 2020 . All capacity data are at year-end.

The electricity generated by the wind energy installed capacity was 206 TWh during 2012, or $7.3 \%$ of EU final electricity consumption. The weighed-average capacity factor, i.e., taking into account that the $12 \mathrm{GW}$ installed in 2012 were installed throughout the year, was $23.4 \%$. The countries with the highest wind share in the electricity mix in 2012 were Denmark $(30 \%)$, Portugal (20.4\%), Spain (18\%), Ireland (16\%) and Germany (8.8\%) (Source: JRC/Eurostat).

Table 5-1. Cumulative Capacity (GW) Installed in the EU

\begin{tabular}{|lrlllllllrr|r|} 
& 2007 & 2008 & 2009 & 2010 & 2011 & 2012 & 2013 & 2014 & $\begin{array}{c}\text { Projected } \\
2015\end{array}$ & $\begin{array}{r}\text { Projected } \\
2020\end{array}$ \\
\hline Land & 55.6 & 63.5 & 73.2 & 82.0 & 90.7 & 101.4 & 110.7 & 120.8 & 131 & 180 \\
\hline Sea & 1.12 & 1.50 & 2.07 & 2.96 & 3.83 & 4.99 & 6.56 & 8.05 & 11 & 23 \\
\hline
\end{tabular}

Table 5-2. Annual Capacity (GW) Installed in the EU

\begin{tabular}{|lrrrrrrrrrrr|} 
& 2007 & 2008 & 2009 & 2010 & 2011 & 2012 & 2013 & 2014 & $\begin{array}{r}\text { Projected } \\
2015\end{array}$ & $\begin{array}{r}\text { Projected } \\
2020\end{array}$ \\
\hline Land & 8.11 & 7.90 & 9.74 & 8.78 & 8.79 & 10.89 & 9.59 & 10,31 & 10.0 & 10.0 \\
\hline Sea & 0.32 & 0.37 & 0.58 & 0.88 & 0.87 & 1.17 & 1.57 & 1.48 & 3.0 & 2.5 \\
\hline
\end{tabular}

\footnotetext{
${ }^{47}$ The Joint Research Centre (JRC), a Directorate General of the European Commission, has as mission "to provide EU policies with independent, evidence-based scientific and technical support throughout the whole policy cycle". In order to fulfil this mission the JRC has developed research capabilities in this case in wind energy technology.
} 


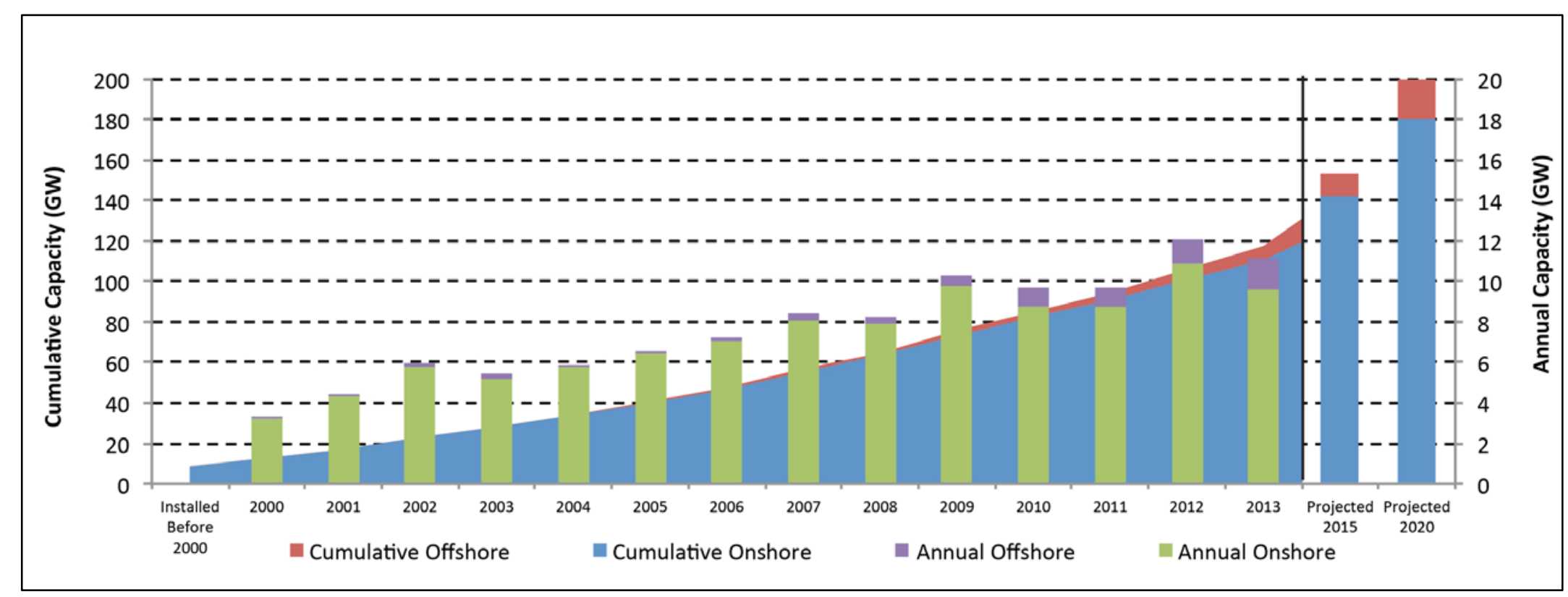

Figure 5-1. Cumulative and annual wind installations in the EU and projections for 2015 and 2020 


\section{Revenue and Policy Incentives}

The predominant support scheme for wind energy production was, during this period, the feed-in tariff (FIT). This system, which lowers some of the risks for plant operators by guaranteeing a fixed income per unit of electricity sold to the grid, has proven the highest effectiveness, $76 \%$ of the EU cumulative installed capacity at the end of 2012 were installed under a FIT system and $7 \%$ under a feed-in premium system. By contrast, $17 \%$ of that capacity was installed under a scheme based on a mandatory quota of wind energy in total electricity generation (also called portfolio scheme) linked to a green certificates system and/or under a tender scheme. Table 5-3 shows which EU Member States have the different types of main support systems (SerranoGonzález \& Lacal-Arántegui, 2015).

Table 5-3. EU Member States and Main Support Systems for Wind Energy

\begin{tabular}{|ll|}
\hline Feed-in tariff & $\begin{array}{l}\text { Austria, Bulgaria, Cyprus, Czech Republic, Spain, France, Greece, } \\
\text { Hungary, Croatia, Ireland, Italy, Lithuania, Luxembourg, Portugal }\end{array}$ \\
\hline Feed-in premium & $\begin{array}{l}\text { Germany, Denmark, Estonia, Spain, Finland, Latvia, Slovenia, } \\
\text { Slovakia, United Kingdom }\end{array}$ \\
\hline Green certificates & Belgium, Poland, Romania, Sweden, United Kingdom \\
\hline Tender & Italy, Latvia, Portugal \\
\hline None & Malta \\
\hline
\end{tabular}

Some remarks are necessary. Some member states are phasing out support or have cancelled it altogether in a more or less abrupt way during the last years. Still, they are included in the table along with what used to be their main support scheme. Some others have or had more than one main support scheme applying to land-based wind, and the developer can choose under certain circumstances. Finally, some countries offer ancillary or "secondary" support schemes for wind energy with a limited impact that by itself would not be able to sustain the growth of wind deployment. Those are grants, loans, tax relief, etc. (Serrano-González \& Lacal-Arántegui, 2015).

Feed-in tariffs and even feed-in premiums are expected to have serious shortcomings for fostering further renewable electricity growth much beyond current rates. In order to allow the integration of very large amounts of variable renewables in the electricity markets and system, the EU recently started to phase out FIT schemes in favor of tender systems. Countries already in this process of change include the Czech Republic, Germany, Spain, and the UK.

\section{Land-Based Wind Energy Project Trends in the EU since 2007}

Wind energy installations considered here are wind plants containing wind turbines with a capacity above $0.5 \mathrm{MW}$, irrespectively of whether they sell electricity to the grid or are used primarily for self-consumption.

The present study is based on a large sample of the land-based installed capacity in the EU between 2007 and 2012. During these six years, 54.2 GW of wind turbine capacity were installed of which the data sample for the analysis of average installed capacity figures and turbine nominal capacity includes $50.8 \mathrm{GW}$ ( $94 \%$ of the total). The analysis of rotor diameter data and specific power evolution are based in $90 \%$ of the total, whereas hub height data are less abundant 
with only $45 \%$ of the total. The so-considered commercial sensibility of cost data forcedly resulted in scarcely available data on capital expenses (which was available for only $16 \%$ of the total installed capacity during the period) and none at all on O\&M costs.

This study has a bias towards including large wind plants because, in the effort for improving the dataset the aim was to increase effectiveness by selecting large wind plants first when doing specific internet-based searches, e.g., for hub height. This bias is likely to be more present in the hub height indicator.

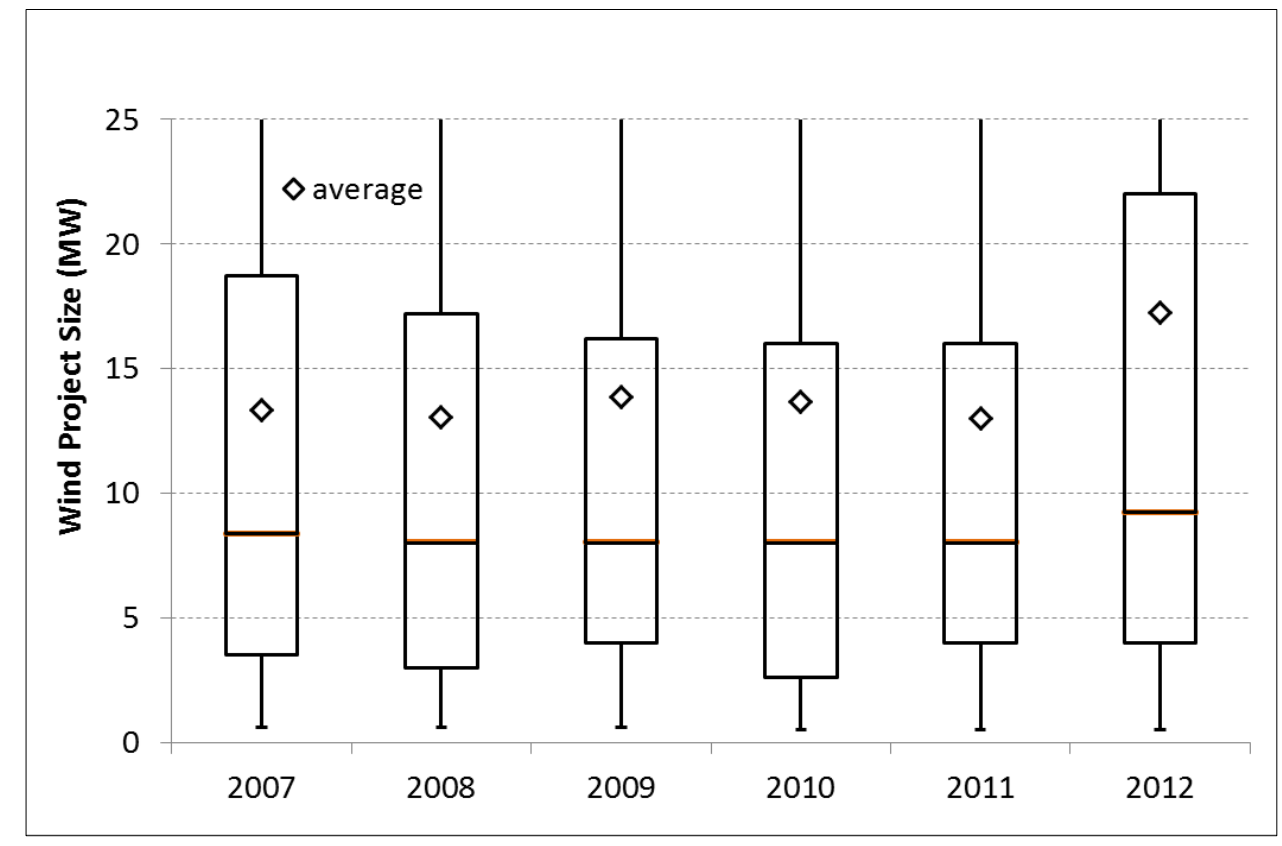

Figure 5-2. Evolution of average wind project size (MW)

\section{Project Features}

For most of the period (2007-2011) the average size of land-based wind plants in Europe has remained fairly constant between $13 \mathrm{MW}$ and $14 \mathrm{MW}$. However, in 2012 a significant increase took place and an average $17.2 \mathrm{MW}$ per project ${ }^{48}$ was reached. Figure 5-2 shows the wind plant size trends 2007-2012. A box and whiskers format is used to represent the projects or turbines that achieved commercial operation in a given year including the median (horizontal line), average (diamond), $25^{\text {th }}$ to $75^{\text {th }}$ percentile (box), and minimum and maximum (whiskers).

It is perhaps interesting to distinguish between the different patterns in the largest markets: whereas Germany, France, and Spain consistently present similar average annual wind plant sizes across the period-yet very different at 7-10 MW in Germany, 11-15 MW in France, and 23-29 MW in Spain - in Italy the annual average size grows steadily from the beginning to the end of the six-year period (from 23 to around $36 \mathrm{MW}$ ). The largest European plant size averages are not in these countries though, but in a new market, Romania, with $70 \mathrm{MW}$ and $73 \mathrm{MW}$ on average in 2013 and 2010 respectively. However, these averages are the result of a single large

\footnotetext{
${ }^{48}$ The parts of a single wind plant were considered that are installed in different years to be separate "projects," also influenced by the fact that in most cases these phases are covered by a separate licence.
} 
project (Fântânele-Cogealac) with two phases commissioned in 2010 (348 MW) and 2012 (253 MW), and thus not necessarily representative of a balanced situation.

The very small size of the average project in Germany (1,054 projects in the six-year sample for $8,816 \mathrm{MW}$, i.e., just above $8 \mathrm{MW}$ per project) shows a very distributed market where community wind plants, per nature of reduced size, have a significant share of all installations. Figure 5-2 also shows that the average wind plant size in the EU at large is well towards the upper side of the range, another signal of the preeminence of small projects along with the existence of a few, very large projects that compensate.

In addition to the Fântânele-Cogealac wind plant, the annually-largest wind plants were installed in the UK (322 MW in 2009), and then significantly smaller wind plants in Italy (138 MW in 2011 and $78 \mathrm{MW}$ in 2007) and Portugal (112 MW in 2008).

The size or rating of the electricity generator, as reflected by the nameplate or nominal power capacity of the individual turbine, has grown steadily from $1.75 \mathrm{MW}$ to $2.25 \mathrm{MW}$, a $29 \%$ increase. Interestingly, the evolution was very steady with intermediate steps of $1.81 \mathrm{MW}$ in 2008, then 1.88 MW, 2.02 MW, and 2.10 MW in 2009, 2010, and 2011 respectively. Figure 5-3 shows the evolution of turbine ratings, and it also shows the extremes: the largest machine installed per nameplate capacity started at $6 \mathrm{MW}$ and it grew to $7.5 \mathrm{MW}$ in 2010, whereas the limit of $0.5 \mathrm{MW}$ to be considered in this study marks the lowest range of nameplate capacities.

The largest land-based turbine, the Enercon E-126, was initially deployed in 2007 at $6.0 \mathrm{MW}$ nominal power. Slowly, this manufacturer brought about innovations (essentially in the control system) which allowed a higher nominal speed and the increase of the generator capacity to 7.5 MW initially and to $7.58 \mathrm{MW}$ more recently. Thus, even when machines installed in 2008 were later upgraded from $6 \mathrm{MW}$ to $7.5 \mathrm{MW}$, for our analysis here only the initial nominal power is taken into account. During the period, the E-126 was installed in Germany, the Netherlands, Austria, and Belgium.

On average, the largest turbines were installed in Austria, Belgium, Denmark ${ }^{49}$, Finland, and Romania. France, Germany, and Portugal were significant markets above the EU average of 1.95 MW, whereas electricity generators in Italy, Poland, Spain, Sweden, and the UK remained below the average.

The turbine rotor diameter, another of the elements that define the evolution of technology through turbine size, has grown steadily as well, from an average $74.8 \mathrm{~m}$ in 2007 (equivalent to a swept area of $4,394 \mathrm{~m}^{2}$ ) to $88.6 \mathrm{~m}$ in 2012 , a swept area of $6,165 \mathrm{~m}^{2}$. This involves an $18.4 \%$ growth in rotor diameter, equivalent to a $40.3 \%$ larger swept area. This growth is crucial to the increase in the effectiveness of wind turbines, because of the strong relationship that exists between swept area and energy produced. If the turbine's nominal power is kept unchanged, a by-product of this growth is a significant increase in capacity factors.

\footnotetext{
${ }^{49}$ See the Danish chapter for an explanation on how legislation influences the ratio between nameplate capacity and rotor size.
} 


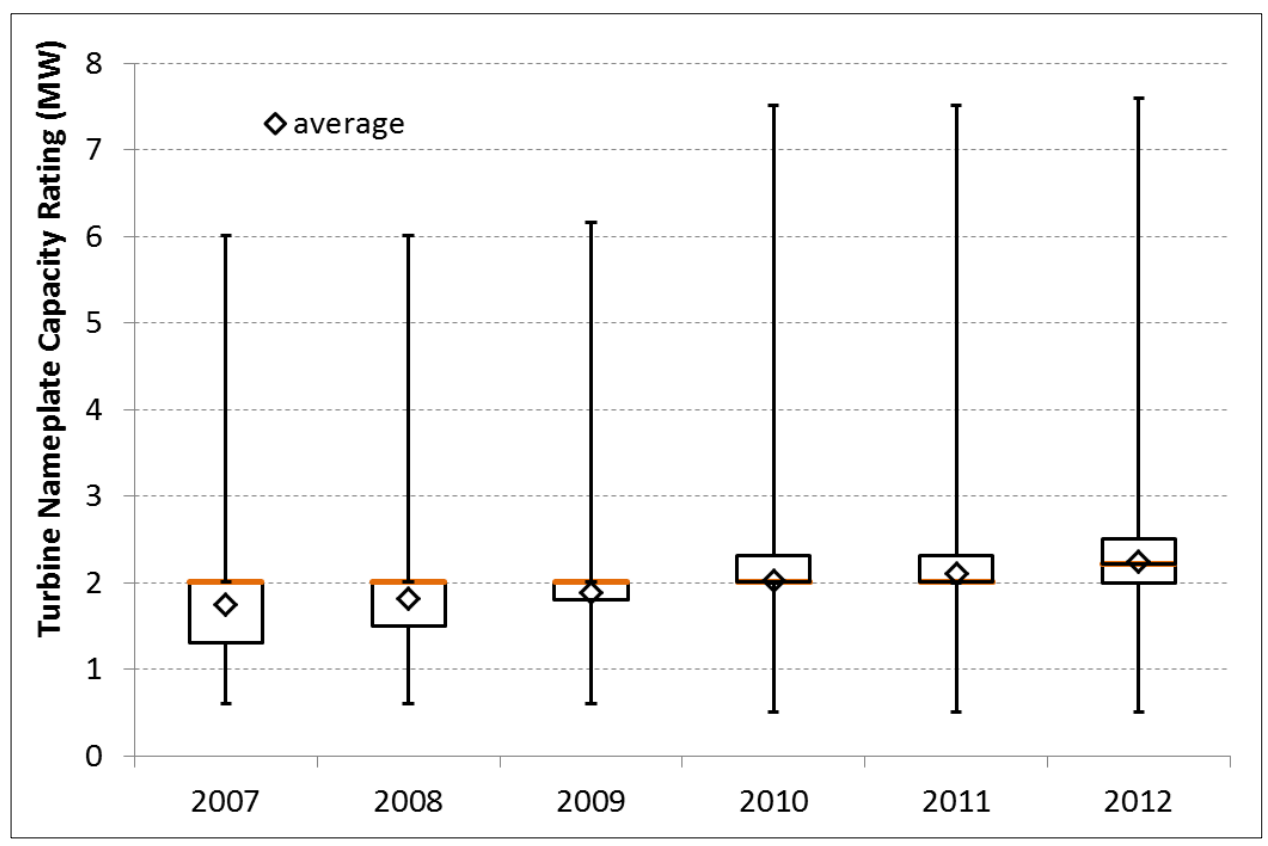

Figure 5-3. Turbine nameplate capacity rating (MW) in the EU, 2007-2012

The largest installed rotors in an individual turbine correspond to the Siemens prototype SWT6.0-154 installed in Denmark (154 m), Spain $(128 \mathrm{~m})$, and a group of four countries (Austria, Belgium, Germany, and the Netherlands) follows with 127-m rotors. Also for these countries in most cases these rotors correspond to prototype wind turbines. On the other hand five countries (Bulgaria, Croatia, Greece, Hungary and Luxemburg) did not install any turbine with a rotor of $100 \mathrm{~m}$ or above during the period.

Regarding average rotor figures, Denmark is the country with the largest rotors overall in the period with $93.5 \mathrm{~m}$, a jump ahead of Latvia $(90.5 \mathrm{~m}$ due to a few recent installation of large-rotor machines), Romania (89.9 m) and Austria $(89.8 \mathrm{~m})$. After Finland $(86.2 \mathrm{~m})$ a packed group of five countries (Belgium, Bulgaria, Germany, Lithuania, and Poland) have averages within $0.6 \mathrm{~m}$, from 83.8 to 84.4. If the latest additions are considered, the installed capacity in 2012, Denmark's 107.3-m rotor average is well ahead of Finland $(102.1 \mathrm{~m})$ and Latvia $(101.0 \mathrm{~m})$, whereas the main markets in 2012 present averages for the year of between $94.6 \mathrm{~m}$ (Poland), $90.5 \mathrm{~m}$ (France, Romania, and Spain), $89 \mathrm{~m}$ (Germany and Sweden), and $76 \mathrm{~m}$ (the United Kingdom). 


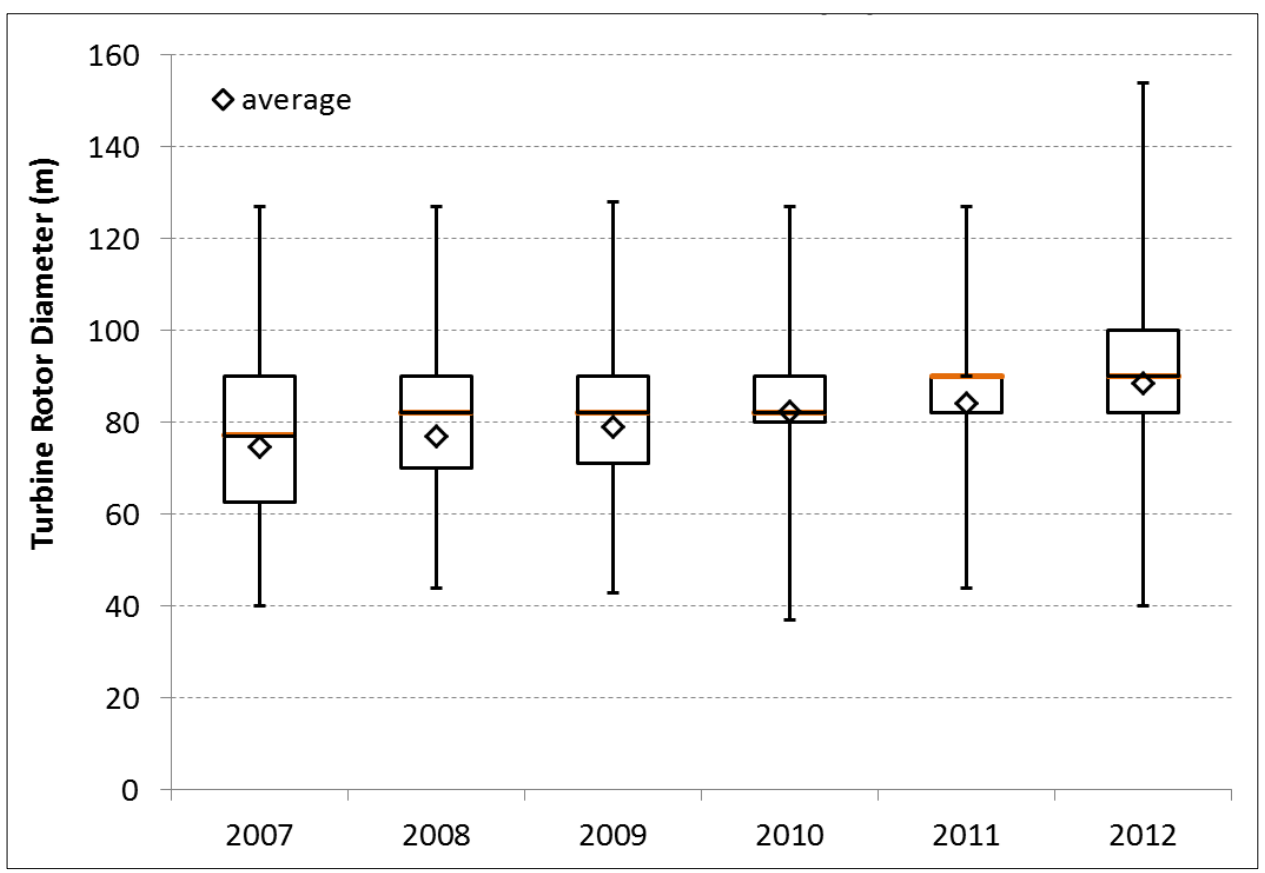

Figure 5-4. Evolution of the turbine rotor diameter in the EU, 2007-2012

Sweden is the market with the highest growth in average rotor diameter during the period, from $61.7 \mathrm{~m}$ in 2007 to $89 \mathrm{~m}$ in 2012, a 44\% growth, closely followed by Poland with $43 \%$ (from 66.2 $\mathrm{m}$ to $94.6 \mathrm{~m}$ ). Denmark exhibits nearly a similar growth $(32 \%)$ compared to 2008 (there are not enough data for 2007). The Netherlands and Ireland are significant markets that grew above the average EU figure whereas Austria, Belgium, Germany, and Portugal grew below the average.

The UK also grew below the average $(8.6 \%$, from 70 to $76 \mathrm{~m})$, and this market shows the third lowest average hub height in the EU at $71.3 \mathrm{~m}$ for the period, following Ireland $(68.2 \mathrm{~m})$ and Greece $(68.3 \mathrm{~m})$. However, the significance of the UK case is higher because, with 3,698 MW installed in the period, it nearly quadruples the installations in Ireland (1,004 MW) or Greece $(1,012 \mathrm{MW})$. The main reason for having smaller rotors is that the UK and Ireland are gifted with the most significant wind resources in Europe which includes many sites suitable for class IEC I turbines, with smaller rotors (for the same rated power) than turbines designed for lowwind areas. However, this reasoning applies independently of the year, and thus it does not justify by itself the evolution of rotors.

Overall, the evolutions of nameplate capacity and of rotor size are likely to be influenced by the offering of the dominant turbine manufacturer in each country and by the respective turbulence levels, aspects not studied in this chapter.

The evolution of the wind turbine specific power presents perhaps less room for conclusions if taken independently of other parameters. 
Figure 5-5 shows that the average specific power, measured in Watts per square meter, decreased from 391 in 2007 to 369 in 2012, and that this decrease was continuous with intermediate steps of $387,382,378$, and $377 \mathrm{~W} / \mathrm{m}^{2}$. Compared to other markets (e.g., see the U.S. chapter) this does not seem a great reduction.

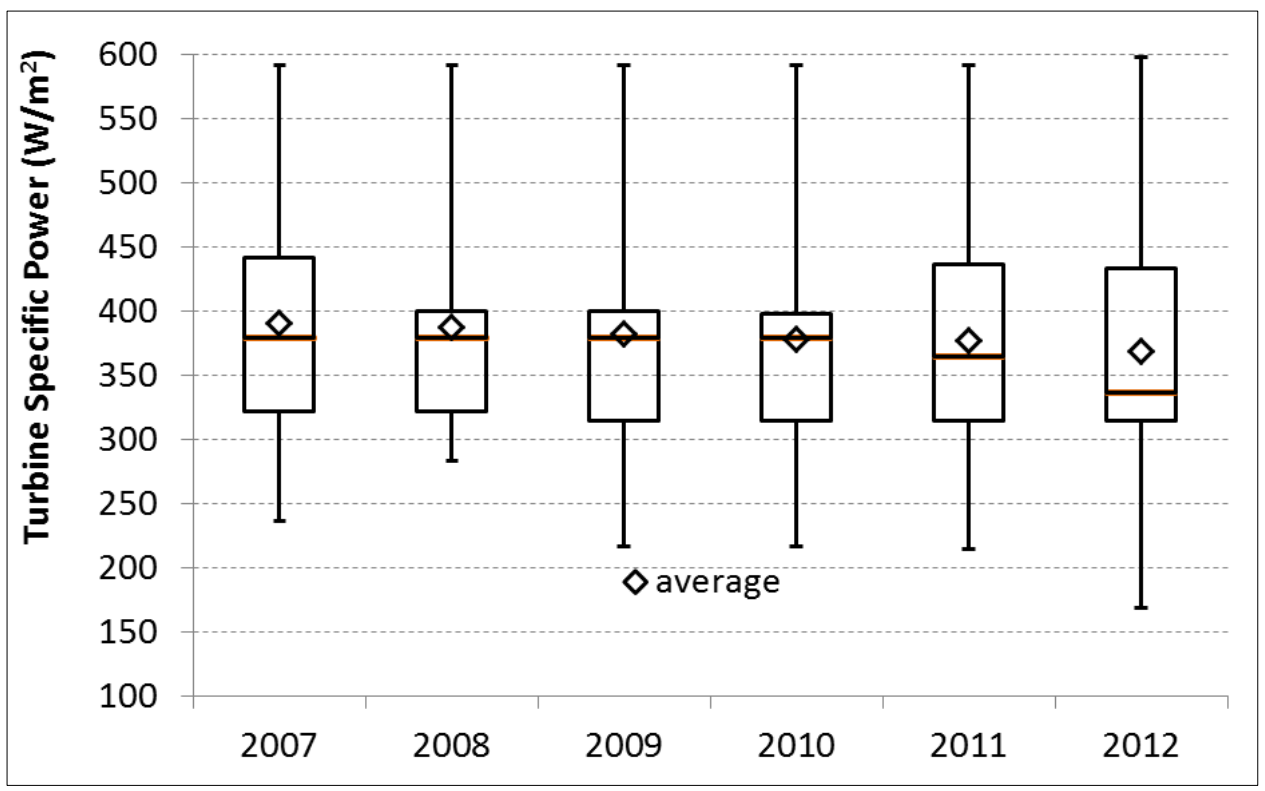

Figure 5-5. Evolution of the specific power of wind turbines installed in the EU from 2007 to 2012

It is also interesting to note that the range between the $25 \%$ and $75 \%$ percentile was particularly narrow (and very similar in size) between 2008 and 2010, whereas it increased in the last two years of this analysis.

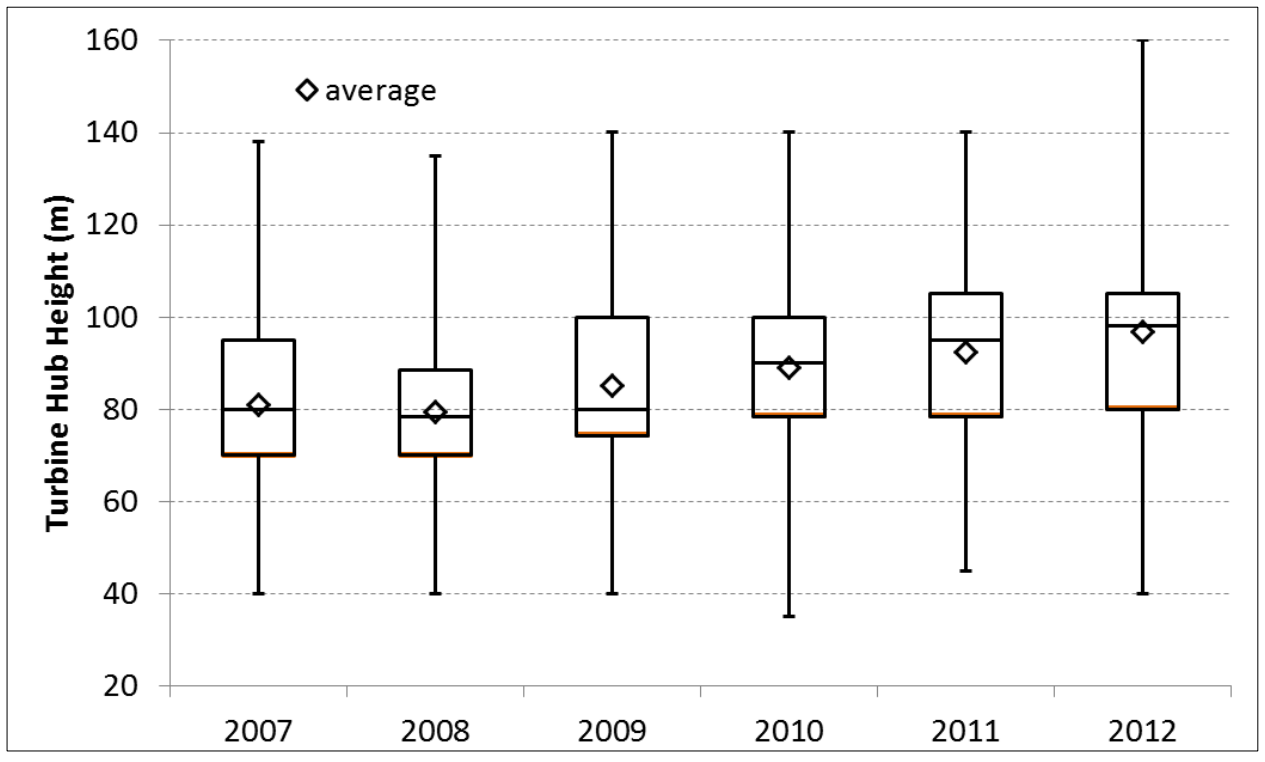

Figure 5-6. Evolution of the hub height in EU wind plants, 2007-2012 
Both maximum and minimum specific powers are influenced by certain machines and therefore few conclusions can be extracted from these figures. The maximum specific power corresponds to the Enercon machines E126-7.50/7.58 with 592 and $598 \mathrm{~W} / \mathrm{m}^{2}$ respectively, and the E44-900 with $592 \mathrm{~W} / \mathrm{m}^{2}$, and all these machines were installed every year in the period. In the other end of the spectrum, the turbines with the minimum specific power installed are the Leitwind LTW77-800/850/1000 $\mathrm{kW}$ at 173, 184, and $216 \mathrm{~W} / \mathrm{m}^{2}$ respectively. However, both the E126 and the Leitwind turbines were relatively uncommon during the period. A focus on more common machines shows that the Nordex N117/2400 (223 W/m²), and the Vestas V100-1.8 and Siemens SWT-2.3-113 (both with $229 \mathrm{~W} / \mathrm{m}^{2}$ ) had the lowest specific power at the same time as a higher impact on the overall fleet level. Significantly, all three machines had been launched shortly before: 2009 in the case of the V100-1.8 and 2011 in the case of the N117/2400 and SWT-2.3113.

The evolution of the turbine hub height shown in Figure 5-6 is, on the one hand, the result of technology improvements seeking the stronger winds at higher heights, and on the other hand the response to the need for higher towers to accommodate larger rotors.

During the period 2007-2012 in the EU the average hub height grew from $81.1 \mathrm{~m}$ to $96.8 \mathrm{~m}$ $(+19 \%)$. The weighted average for the sample varied only slightly, from $81.9 \mathrm{~m}$ in 2007 to 96.6 $\mathrm{m}$ in $2012(+18 \%)$.

Average hub heights were higher in Austria (109.2 m) and Germany (101.7 m), as both are countries that generally have low wind resources. However, the tallest average turbines in 2012 were installed in Finland $(122.7 \mathrm{~m})$, followed by Germany $(118.9 \mathrm{~m})$, and Austria $(111.2 \mathrm{~m})$. The tallest turbine installed was in Poland in 2012: a 160-m, lattice steel prototype by Fuhrländer. In Germany, Fuhrländer, Vestas, Enercon and Nordex installed 140-m towers each year from 2009 onwards.

In conclusion, the trend during the period under study was to increase the size of the rotor more than the nominal power was increased, and this was shown by the reduction in the average specific power.

\section{Project Performance}

Figure 5-7 shows a summary of wind energy performance aggregated at the EU level: installed capacity, electricity generation, and annual capacity factor. The ten-year average $\mathrm{CF}(22.3 \%)$ is shown for reference.

Unfortunately the lack of reliable data at EU level prevents the distinction of the performance of turbines installed different years in one given year-only an all-turbine, yearly average, per country split analysis is available from Eurostat data. However, an approximation to project performance can be taken from these data per country or aggregated at EU level (see Figure 5-7), which covers both land-based and offshore production.

The EU aggregated level shows a clear increase in CF during the last ten years for the whole fleet, from just below $20 \%$ in 2000 to $23.4 \%$ in 2012 . However, it does not reveal why this improvement took place or where. The figure also shows that annual figures can vary significantly, e.g., because of lower overall wind resources a given year, as it happened in 2010 . 


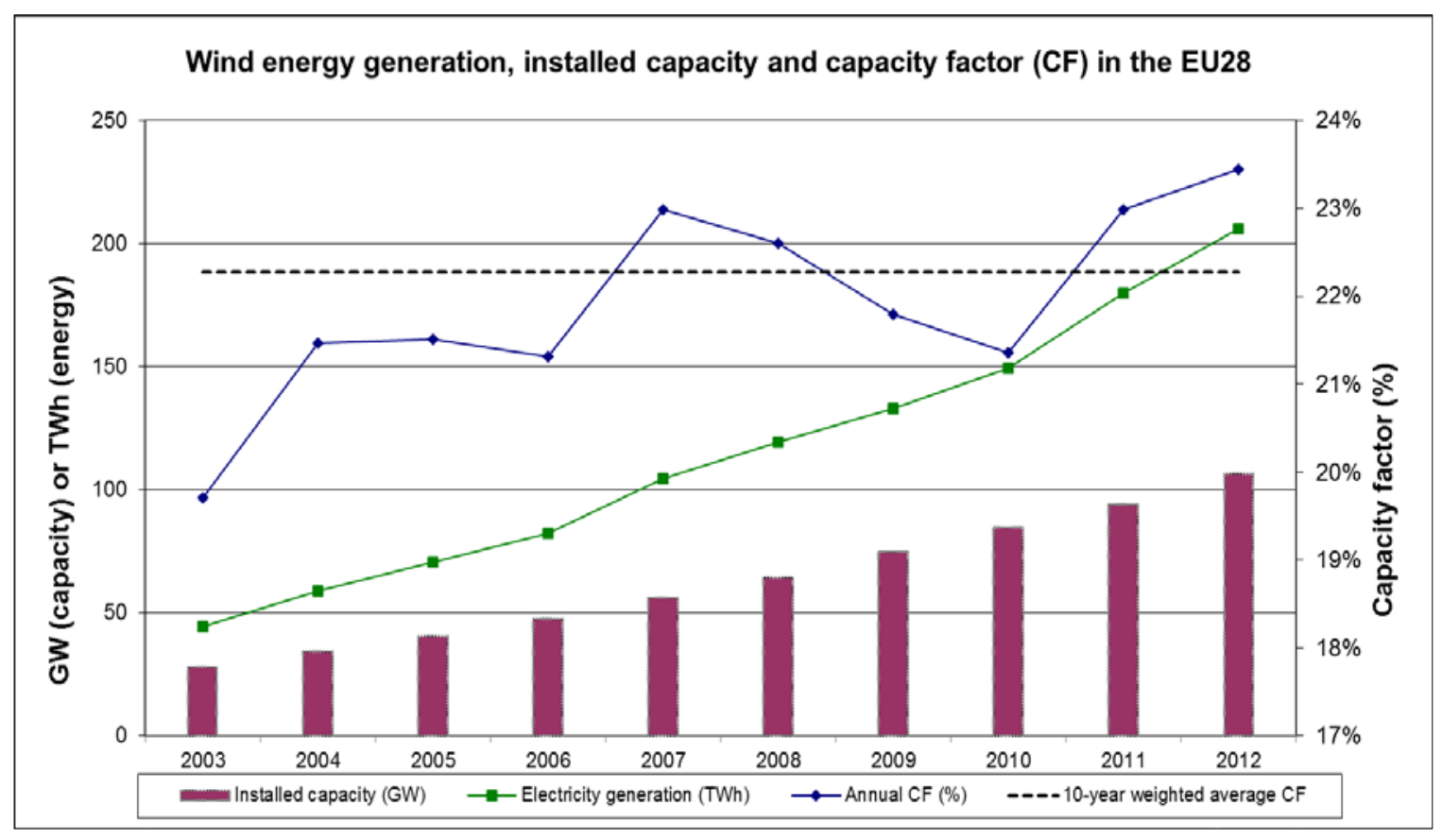

Figure 5-7. Summary of wind energy performance in the EU

Country data for selected countries are included in Figure 5-8 based as well on data reported to Eurostat. This graph is very interesting in that it shows (a) the important effects of aggregating at European level in smoothing large national year-to-year differences in production, and (b) that large differences in full-load hours occur already between countries.

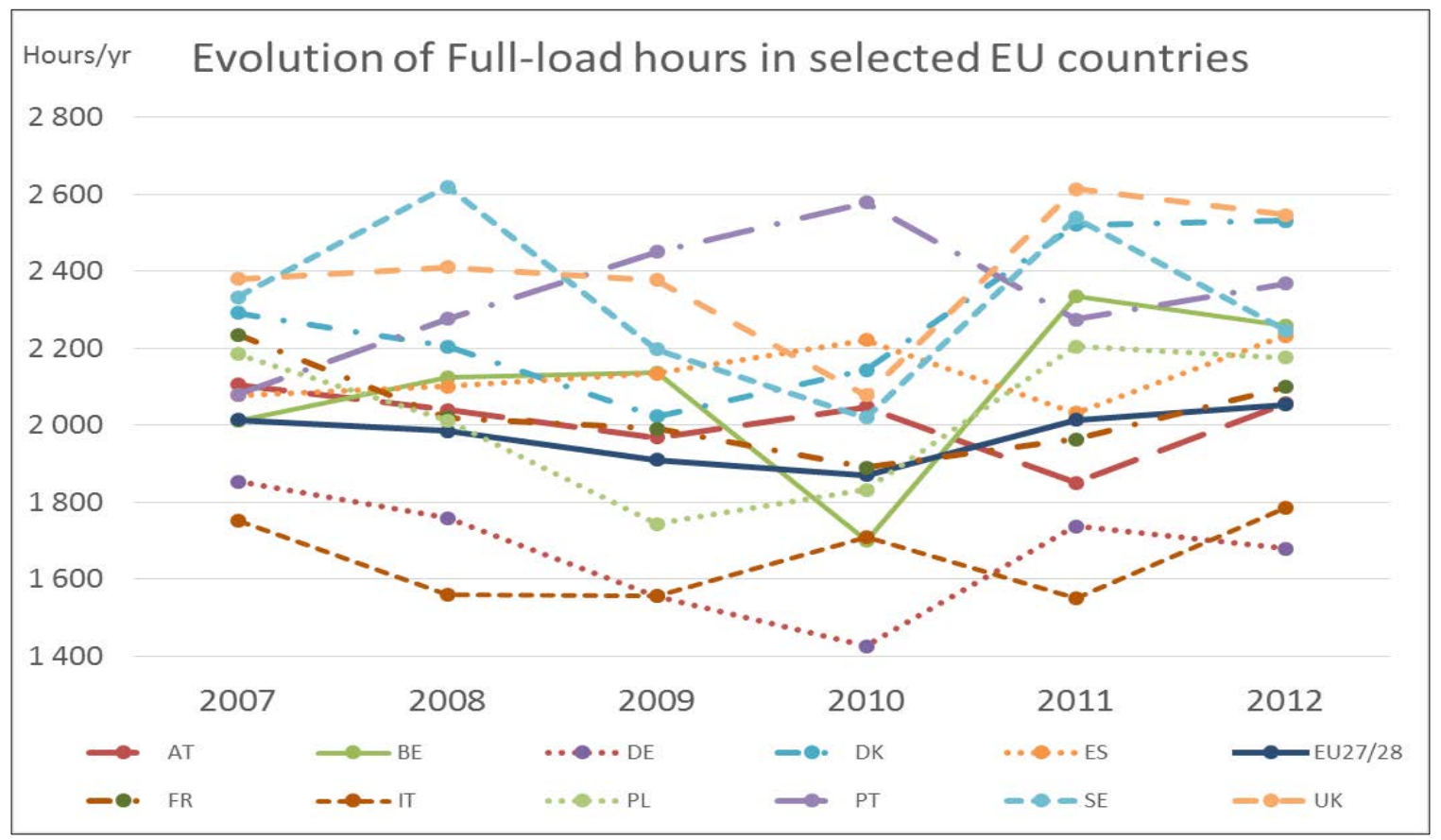

Source: JRC/Eurostat

Figure 5-8. Country-level performance in full-load hours per year 


\section{Investment Costs}

The statistical sample for cost information is very small compared to the total installed capacity, at around $16 \%$. In addition, the data source is different: whereas the JRC database of wind installations was used for technology indicators, for costs indicators the European part of the Bloomberg New Energy Finance database of wind project was taken as the basis for research.

Even with such a small dataset, the emerging trend is strongly consistent with other industry intelligence and with other reports from institutions such as the member countries of the IEA Wind Implementation Agreement: costs skyrocketed up to 2010 and then started to descend, first slowly (2011), then more clearly (2012).

Figure 5-9 shows this evolution and the above-mentioned trend is clear from several indicators: average, median, and percentile $(25 \%-75 \%)$ gap.

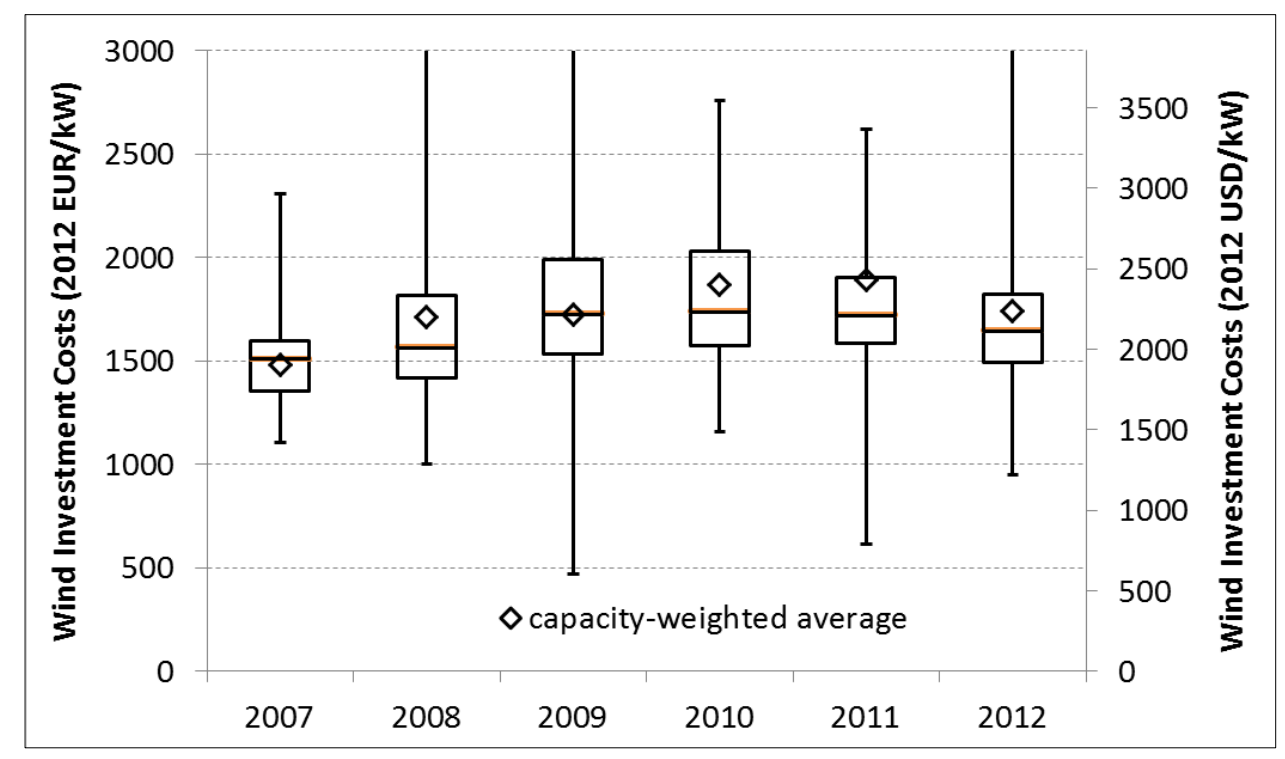

Figure 5-9. Project investment costs in the EU, 2007-2012

A second element is interesting to note: as in the case of turbine nominal power and unlike all other technical aspects studied above, the gap between the $25 \%$ and the $75 \%$ percentile is generally narrow. This shows a high concentration of project costs in a narrow band, and the presence of other projects that are extremely costly or surprisingly inexpensive. An analysis of what causes these differences is beyond the purpose of this report, but it is generally understood that complex terrain increases transport and installation costs; economies of scale reduce costs; the extension or repowering of an existing wind plant may offer synergies that result in lower costs, etc. Extremely high cost instances can be allocated to projects with a high demonstration element or prototypes and, even when included here, they are not representative of commercial costs.

The average capacity-weighted wind plant capital cost in the sample climbed from $€ 1,483 / \mathrm{kW}$ in 2007 to $€ 1,890 / \mathrm{kW}$ in 2011 and then reduced to $€ 1,743 / \mathrm{kW}$ in 2012 . 
This figure has some boundary conditions that are explained here. To start with, the sample size $(16 \%)$ is very small; on the other hand cross-checking with turbine prices from the same source (BNEF), and typical ratios turbine to CapEx cost (65\% to 70\%), suggests a lower figure. For example, for 2012 an average cost of the turbine of $€ 940 / \mathrm{kW}$ globally (except China) was exposed in Bloomberg New Energy Finance's "Wind turbine price index H2 2013" report. If a $67 \%$ ratio of turbine cost to CapEx is assumed, the 2012 average cost would be $€ 1,400 / \mathrm{kW}$ of installed capacity, significantly lower than the $€ 1,743 / \mathrm{kW}$ mentioned above.

\section{References for Chapter 5}

Eurostat, statistical office of the European Union. http://ec.europa.eu/eurostat

EWEA. (2015a). Wind in power. 2014 European statistics. Brussels: European Wind Energy Association.

EWEA. (2015b). The European offshore wind industry - key trends and statistics 2014. Brussels: European Wind Energy Association.

Serrano-González, J., \& Lacal-Arántegui, R. (2015). The regulatory framework for wind energy in EU Member States. Part 1 of the study on the social and economic value of wind energy WindValueEU. Luxembourg: Publications Office of the European Union.

\section{Appendix 5-A. Sample Size and Project Data for the European Union}

This appendix contains statistics representing wind project characteristics that are illustrated in the chapter. Table 1-9 describes the sample size of data represented in the subsequent tables. The values in the table correspond to the installed wind project capacity in a given year, or the percentage of annual installed capacity, that is included in the database. For example, an entry of $100 \%$ for Wind Turbine Hub Height means that the statistics shown in the corresponding table and figure for hub height represent $100 \%$ of the turbines installed in that year. 
Table 5-4. Definitions and Sample Size for the EU

\section{COUNTRY: EUROPEAN UNION (EU-27)}

DEFINITION OF UTILITY SCALE WIND

"Utility scale" is considered here as any wind farm or wind turbine with a capacity above $1 \mathrm{MW}$,

irrespectively of whether they sell electricity to the grid or are used primarily for self consumption

\section{YEAR DATA AGGREGATION}

Data aggregation is not needed for the EU

\section{OTHER NOTES}

Total wind installations from EWEA statistics (all minus offshore)

\begin{tabular}{|c|c|c|c|c|c|c|}
\hline \multirow[t]{2}{*}{ SAMPLE } & \multicolumn{6}{|c|}{ Capacity (Megwatts) } \\
\hline & 2007 & 2008 & 2009 & 2010 & 2011 & 2012 \\
\hline \multicolumn{7}{|c|}{ Annual Installations -- Land-Based, Utility-Scale Only } \\
\hline Total Wind Power Additions & 8,236 & 7,895 & 9,740 & 8,777 & 8,790 & 10,888 \\
\hline \multicolumn{7}{|l|}{ Sample Size -- Land-Based, Utility-Scale Only } \\
\hline Wind Project Size & 13.3 & 13.0 & 13.9 & 13.7 & 13.0 & 17.2 \\
\hline Wind Turbine Nameplate Capacity Rating & 1.75 & 1.82 & 1.88 & 2.02 & 2.10 & 2.25 \\
\hline Wind Turbine Rotor Diameter & 74.8 & 77.1 & 79.0 & 82.4 & 84.1 & 88.6 \\
\hline Wind Turbine Hub Height & 81.1 & 79.3 & 85.2 & 89.1 & 92.3 & 96.8 \\
\hline Wind Turbine Specific Power & 391 & 387 & 382 & 378 & 377 & 369 \\
\hline \multicolumn{7}{|l|}{ Wind Turbine IEC Class } \\
\hline \multicolumn{7}{|l|}{ Annual Average Wind Speed } \\
\hline \multicolumn{7}{|l|}{ Full Load Hours (generation in 2012) } \\
\hline Investment Costs & 1,905 & 2,202 & 2,218 & 2,398 & 2,429 & 2,240 \\
\hline Operations and Maintenance Costs & na & na & na & na & na & na \\
\hline Financing Costs & na & na & na & na & na & na \\
\hline \multicolumn{7}{|l|}{ Sample Size (\%) -- Land-Based, Utility-Scale Only } \\
\hline Wind Project Size & $101 \%$ & $101 \%$ & $107 \%$ & $95 \%$ & $87 \%$ & $75 \%$ \\
\hline Wind Turbine Nameplate Capacity Rating & $105 \%$ & $101 \%$ & $107 \%$ & $96 \%$ & $89 \%$ & $77 \%$ \\
\hline Wind Turbine Rotor Diameter & $1 \%$ & $1 \%$ & $1 \%$ & $1 \%$ & $1 \%$ & $1 \%$ \\
\hline Wind Turbine Hub Height & $1 \%$ & $1 \%$ & $1 \%$ & $1 \%$ & $1 \%$ & $1 \%$ \\
\hline Wind Turbine Specific Power & $5 \%$ & $5 \%$ & $4 \%$ & $4 \%$ & $4 \%$ & $3 \%$ \\
\hline Wind Turbine IEC Class & $0 \%$ & $0 \%$ & $0 \%$ & $0 \%$ & $0 \%$ & $0 \%$ \\
\hline Annual Average Wind Speed & $0 \%$ & $0 \%$ & $0 \%$ & $0 \%$ & $0 \%$ & $0 \%$ \\
\hline Full Load Hours (generation in $2012 / 2013$ ) & $0 \%$ & $0 \%$ & $0 \%$ & $0 \%$ & $0 \%$ & $0 \%$ \\
\hline Investment Costs & $23 \%$ & $28 \%$ & $23 \%$ & $27 \%$ & $28 \%$ & $21 \%$ \\
\hline Operations and Maintenance Costs & NA & NA & NA & NA & NA & NA \\
\hline Financing Costs & NA & NA & NA & NA & NA & NA \\
\hline
\end{tabular}


Table 5-5. Wind Project Size Statistics

\begin{tabular}{|l|r|r|r|r|r|r|} 
Wind Project Size (MW) \\
\hline & $\mathbf{2 0 0 7}$ & $\mathbf{2 0 0 8}$ & $\mathbf{2 0 0 9}$ & $\mathbf{2 0 1 0}$ & $\mathbf{2 0 1 1}$ & $\mathbf{2 0 1 2}$ \\
\hline n (\# projects) & 625 & 611 & 753 & 611 & 584 & 473 \\
\hline median & 8.4 & 8.0 & 8.0 & 8.0 & 8.0 & 9.2 \\
\hline 25th percentile & 3.5 & 3.0 & 4.0 & 2.6 & 4.0 & 4.0 \\
\hline 75th percentile & 18.7 & 17.2 & 16.2 & 16.0 & 16.0 & 22.0 \\
\hline minimum & 0.6 & 0.6 & 0.6 & 0.5 & 0.5 & 0.5 \\
\hline maximum & 77.4 & 112.0 & 322.0 & 347.5 & 138.0 & 252.5 \\
\hline average & 13.3 & 13.0 & 13.9 & 13.7 & 13.0 & 17.2 \\
\hline Sample (MW) & 8331 & 7968 & 10446 & 8348 & 7603 & 8152 \\
\hline
\end{tabular}

Salient Notes: All projects $>=0.5 \mathrm{MW}$, with all turbines $>=0.5 \mathrm{MW}$, and which were not behind the meter (i.e., "on-site" in terms of off-taker)

Table 5-6. Turbine Nameplate Capacity Rating Statistics

\begin{tabular}{|l|r|r|r|r|r|r|} 
Wind Turbine Nameplate Capacity Rating (MW) \\
\hline & $\mathbf{2 0 0 7}$ & $\mathbf{2 0 0 8}$ & $\mathbf{2 0 0 9}$ & $\mathbf{2 0 1 0}$ & $\mathbf{2 0 1 1}$ & $\mathbf{2 0 1 2}$ \\
\hline n (\# turbines) & 4962 & 4366 & 5536 & 4179 & 3716 & 3738 \\
\hline median & 2 & 2 & 2 & 2 & 2 & 2.21 \\
\hline 25th percentile & 1.3 & 1.5 & 1.8 & 2 & 2 & 2 \\
\hline 75th percentile & 2 & 2 & 2 & 2.3 & 2.3 & 2.5 \\
\hline minimum & 0.6 & 0.6 & 0.6 & 0.5 & 0.5 & 0.5 \\
\hline maximum & 6 & 6 & 6.15 & 7.5 & 7.5 & 7.58 \\
\hline average & 1.75 & 1.82 & 1.88 & 2.02 & 2.10 & 2.25 \\
\hline Sample (MW) & 8307 & 7937 & 10446 & 8344 & 7546 & 8139 \\
\hline
\end{tabular}

Salient Notes: All turbines with a known capacity $>=0.5 \mathrm{MW}$, for all projects $>=0.5 \mathrm{MW}$ that were not behind the meter (i.e., "on-site" in terms of off-taker)

Table 5-7. Turbine Rotor Diameter Statistics

\begin{tabular}{|l|r|r|r|r|r|r|} 
Wind Turbine Rotor Diameter $(\mathbf{m})$ \\
\hline & $\mathbf{2 0 0 7}$ & $\mathbf{2 0 0 8}$ & $\mathbf{2 0 0 9}$ & $\mathbf{2 0 1 0}$ & $\mathbf{2 0 1 1}$ & $\mathbf{2 0 1 2}$ \\
\hline n (\# turbines) & 4770 & 4167 & 5235 & 4128 & 3622 & 3645 \\
\hline median & 77 & 82 & 82 & 82 & 90 & 90 \\
\hline 25th percentile & 62.5 & 70 & 71 & 80 & 82 & 82 \\
\hline 75th percentile & 90 & 90 & 90 & 90 & 90 & 100 \\
\hline minimum & 40 & 44 & 43 & 37 & 44 & 40 \\
\hline maximum & 127 & 127 & 128 & 127 & 127 & 154 \\
\hline average & 74.8 & 77.1 & 79.0 & 82.4 & 84.1 & 88.6 \\
\hline Sample (MW) & 7932 & 7570 & 9845 & 8258 & 7341 & 7971 \\
\hline
\end{tabular}

Salient Notes: All turbines with a known rotor diameter (i.e., not missing) and capacity $>=0.5 \mathrm{MW}$, for all projects $>=0.5 \mathrm{MW}$ that were not behind the meter (i.e., "on-site" in terms of off-taker) 
Table 5-8. Turbine Specific Power Statistics

\begin{tabular}{|l|r|r|r|r|r|r|} 
Wind Turbine Specific Power $\left(\mathbf{W} / \mathbf{m}^{2}\right)$ \\
\hline & $\mathbf{2 0 0 7}$ & $\mathbf{2 0 0 8}$ & $\mathbf{2 0 0 9}$ & $\mathbf{2 0 1 0}$ & $\mathbf{2 0 1 1}$ & $\mathbf{2 0 1 2}$ \\
\hline n (\# turbines) & 4770 & 4167 & 5235 & 4128 & 3622 & 3645 \\
\hline median & 379 & 379 & 379 & 379 & 364 & 336 \\
\hline 25th percentile & 322 & 322 & 314 & 314 & 314 & 314 \\
\hline 75th percentile & 442 & 400 & 400 & 398 & 436 & 433 \\
\hline minimum & 236 & 283 & 217 & 217 & 214 & 169 \\
\hline maximum & 592 & 592 & 592 & 592 & 592 & 598 \\
\hline average & 391 & 387 & 382 & 378 & 377 & 369 \\
\hline Sample (MW) & 7932 & 7570 & 9845 & 8258 & 7341 & 7971 \\
\hline
\end{tabular}

Salient Notes: All turbines with a known specific power (i.e., not missing) and capacity $>=0.5 \mathrm{MW}$, for all projects $>=0.5 \mathrm{MW}$ that were not behind the meter (i.e., "on-site" in terms of off-taker)

Table 5-9. Turbine Hub Height Statistics

\begin{tabular}{|l} 
Wind Turbine Hub Height (m) \\
\begin{tabular}{|l|r|r|r|r|r|r|}
\hline & $\mathbf{2 0 0 7}$ & $\mathbf{2 0 0 8}$ & $\mathbf{2 0 0 9}$ & $\mathbf{2 0 1 0}$ & $\mathbf{2 0 1 1}$ & $\mathbf{2 0 1 2}$ \\
\hline n (\# turbines) & 1633 & 1998 & 2618 & 2239 & 1840 & 1598 \\
\hline median & 80 & 78.5 & 80 & 90 & 95 & 98 \\
\hline 25th percentile & 70 & 70 & 74.3 & 78.5 & 78.5 & 80 \\
\hline 75th percentile & 95 & 88.6 & 100 & 100 & 105 & 105 \\
\hline minimum & 40 & 40 & 40 & 35 & 45 & 40 \\
\hline maximum & 138 & 135 & 140 & 140 & 140 & 160 \\
\hline average & 81.1 & 79.3 & 85.2 & 89.1 & 92.3 & 96.8 \\
\hline Sample (MW) & 3133 & 3769 & 5339 & 4699 & 3881 & 3718 \\
\hline
\end{tabular}
\end{tabular}

Salient Notes: All turbines with a known hub height (i.e., not missing) and capacity >= $0.5 \mathrm{MW}$, for all projects $>=0.5 \mathrm{MW}$ that were not behind the meter (i.e., "on-site" in terms of off-taker) 
Table 5-10. Project Investment Costs Statistics

\begin{tabular}{|l|r|r|r|r|r|r|} 
Wind Project Investment Costs (2012 EUR per kW) \\
\hline & $\mathbf{2 0 0 7}$ & $\mathbf{2 0 0 8}$ & $\mathbf{2 0 0 9}$ & $\mathbf{2 0 1 0}$ & $\mathbf{2 0 1 1}$ & $\mathbf{2 0 1 2}$ \\
\hline median & 1510 & 1565 & 1726 & 1736 & 1719 & 1644 \\
\hline 25th percentile & 1355 & 1421 & 1535 & 1573 & 1584 & 1494 \\
\hline 75th percentile & 1595 & 1817 & 1992 & 2028 & 1901 & 1823 \\
\hline minimum & 1108 & 1000 & 470 & 1160 & 616 & 950 \\
\hline maximum & 2309 & 4993 & 4102 & 2758 & 2620 & 3288 \\
\hline capacity-weighted average & 1483 & 1714 & 1726 & 1866 & 1890 & 1743 \\
\hline
\end{tabular}

Wind Project Investment Costs (2012 USD per kW)
\begin{tabular}{|l|r|r|r|r|r|r|}
\hline & $\mathbf{2 0 0 7}$ & $\mathbf{2 0 0 8}$ & $\mathbf{2 0 0 9}$ & $\mathbf{2 0 1 0}$ & $\mathbf{2 0 1 1}$ & $\mathbf{2 0 1 2}$ \\
\hline median & 1940 & 2010 & 2218 & 2231 & 2209 & 2113 \\
\hline 25th percentile & 1741 & 1825 & 1972 & 2021 & 2035 & 1920 \\
\hline 75th percentile & 2049 & 2335 & 2559 & 2606 & 2442 & 2342 \\
\hline minimum & 1423 & 1285 & 604 & 1491 & 791 & 1221 \\
\hline maximum & 2967 & 6415 & 5271 & 3544 & 3366 & 4225 \\
\hline capacity-weighted average & 1905 & 2202 & 2218 & 2398 & 2429 & 2240 \\
\hline
\end{tabular}




\section{Chapter 6. Wind Energy Development in the United States}

Authors: M. Maureen Hand (National Renewable Energy Laboratory), Kathy Belyeu (Belyeu Consulting), Eric Lantz, (National Renewable Energy Laboratory), Ryan Wiser (Lawrence Berkeley National Laboratory), Mark Bolinger (Lawrence Berkeley National Laboratory), and Ben Hoen (Lawrence Berkeley National Laboratory)

This chapter should be cited as: Hand, M. M., Belyeu, K., Lantz, E., Wiser, R., and Bolinger, M., (2015). "Wind Energy Development in the United States," Chapter 6. Hand, M. M., ed., IEA Wind Task 26 - Wind Technology, Cost, and Performance Trends in Denmark, Germany, Ireland, Norway, the European Union, and the United States: 2007-2012. NREL/TP-6A2064332. Golden, CO: National Renewable Energy Laboratory. pp. 137-160.

\section{Domestic Wind Energy Capacity, Production, and Targets}

Annual wind power capacity additions in the United States achieved record levels in 2012, motivated by the then-planned expiration of federal tax incentives at the end of 2012 and recent improvements in the cost and performance of wind power technology. Wind power constituted $43 \%$ of all electric generation capacity additions in the United States in 2012, the largest source of all new generating capacity in that year. As a result of growth in 2012 and previous years, the United States Energy Information Administration (EIA 2014) reports that wind power provided $4.5 \%$ of the nation's electricity supply in 2013 .

At the same time, the United States wind power industry continues to face uncertain times. Due to uncertainty about the extension of federal tax incentives, project pipelines were heavily depleted in 2012 and 2013 was the slowest year for capacity additions in nearly a decade. Continued low natural gas prices, modest electricity demand growth, and limited near-term demand from state renewables portfolio standards (RPS) have also put a damper on mediumterm (after 2016) industry growth expectations, with federal tax incentives supporting near term growth through 2016.

Figure 6-1 and Tables 6-1 and 6-2 show wind power capacity installations in the United States (Wiser and Bolinger, 2014), as well as near- and medium-term projections for 2015 and 2020, respectively (BNEF, 2014). ${ }^{50}$ The United States does not have legally binding long-term targets for national wind power development. President Obama has set a (non-binding) target of doubling the amount of electricity generated by wind, solar, and geothermal sources from 2012 levels by 2020 and has issued a number of Executive Orders directing government agencies to consume $20 \%$ of electricity from renewable sources by 2020 . A variety of states have also developed legally binding targets for renewable energy, through state-level RPS programs. Projections for 2015 and 2020 developed by BNEF are therefore based on project pipeline analysis, market condition expectations, state policy requirements, and other insights.

As of 2014, there are no commercial offshore wind plants installed in the United States. Interest exists in various regions of the country, however, and some projects are in the later stages of development. This industry is in the very earliest stages of development in the United States, and as a result, faces many uncertainties and opportunities. Siting, permitting, and development

\footnotetext{
${ }^{50}$ All capacity is year-end data representing all turbines over $100 \mathrm{~kW}$ in size.
} 
activities will be aided by the Department of Interior's regulatory approval developments (the first competitive leases were issued in 2013). Infrastructure to support installation and operation of offshore wind plants is developing, and recent support for demonstration projects from the U.S. Department of Energy is expected to accelerate these activities. One proposed project has arranged PPAs and has initiated construction activities in 2013 in order to qualify for the federal tax-based support mechanisms. In 2013, approximately $4.9 \mathrm{GW}$ of proposed offshore wind projects were in advanced stages of development in that they have a signed PPA, have received approval for an interim limited lease or a commercial lease in state or federal waters, and/or have conducted baseline or geophysical studies at the proposed site with a meteorological tower erected and collecting data, boreholes drilled, or geological and geophysical data acquisition systems in place. It is likely that some of these projects will be constructed before 2020 as shown in the 2015 and 2020 projections in Figure 6-1 and in Tables 6-1 and 6-2.

\section{Revenue and Policy Incentives}

The federal renewable electricity production tax credit (PTC) is a per-kilowatt-hour tax credit for electricity generated by qualified energy resources. In 2009, renewable energy project developers were also given a choice to instead elect an up-front cost-based investment tax credit (ITC) based on the initial amount invested in a project. At the beginning of 2013, the deadline for eligibility for the production and investment tax credits was extended through 2013, and the terms were changed so that start of construction rather than placed in service became the basis for eligibility. Another extension was passed at the end of 2014 such that eligibility was extended to projects that demonstrated initiation of construction by end of 2014. A "safe harbor" clause will provide eligibility for projects that are operational by end of year 2016 .

In addition to the PTC, investors in most new renewable power generation projects are able to accelerate the depreciation of the renewable project assets. This enables them to defer related federal taxable income and obligations in the early years of the projects. Together, the tax credits and the accelerated depreciation compose what is referred to as the "tax benefits" of a renewable project.

In 2009, after the 2008 global financial crisis, Congress responded to the lack of tax equity investors with a provision to allow developers to claim a cash payment in lieu of the taxdependent ITC or PTC. The program entitled project developers to receive $30 \%$ of a project's capital cost in the form of an upfront cash payment (notionally the same value as the ITC mentioned previously). This freed developers from having to rely as extensively on tax equity investors to monetize the federal tax credits and attracted new investors to the market (Mendelsohn et al. 2012). The cash grant program expired on 31 December 2011, with projects that started construction prior to that date eligible to receive the award.

At the end of 2014, RPS policies existed in 29 states and Washington D.C. An RPS is a requirement that a certain amount of electricity come from renewable sources. Given the rapid growth in renewable generation over the last decade, however, near-term incremental RPS demand is somewhat modest: existing laws are projected to drive average annual renewable energy additions of just 3-4 GW/yr between 2013 and 2025, only a portion of which will be from wind (Wiser and Bolinger 2014). 


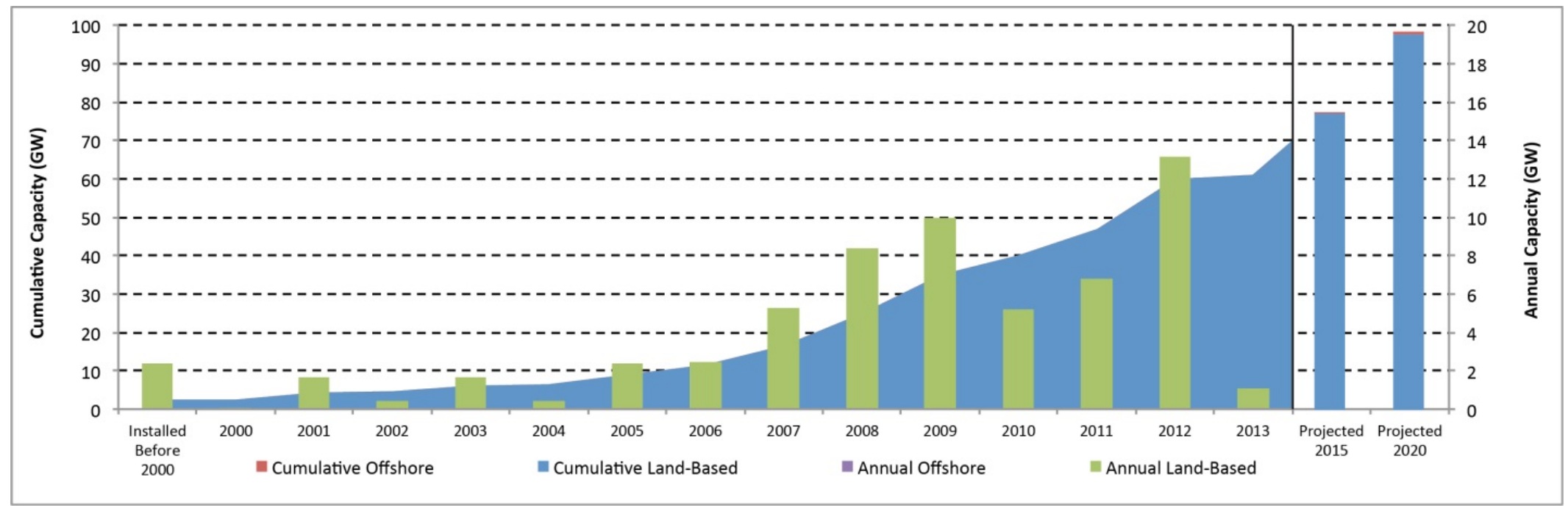

Figure 6-1. Cumulative and annual wind installations in the United States

Table 6-1. Cumulative and Annual Capacity (GW) Installed in the United States

\begin{tabular}{|c|c|c|c|c|c|c|c|c|c|c|c|c|c|c|c|c|c|c|}
\hline \multicolumn{17}{|c|}{ Wind Project Capacity and Targets (GW) } & \multicolumn{2}{|c|}{ PROJECTIONS } \\
\hline & & $<2000$ & 2000 & 2001 & 2002 & 2003 & 2004 & 2005 & 2006 & 2007 & 2008 & 2009 & 2010 & 2011 & 2012 & 2013 & 2015 & 2020 \\
\hline \multirow[t]{2}{*}{ Cumulative } & Cumulative & 2.4 & 2.5 & 4.1 & 4.6 & 6.2 & 6.6 & 9.0 & 11.5 & 16.7 & 25.1 & 35.1 & 40.3 & 46.9 & 60.0 & 61.1 & 76.1 & 95.2 \\
\hline & Cumulative & 0.0 & 0.0 & 0.0 & 0.0 & 0.0 & 0.0 & 0.0 & 0.0 & 0.0 & 0.0 & 0.0 & 0.0 & 0.0 & 0.0 & 0.0 & 0.2 & 1.2 \\
\hline \multirow[t]{2}{*}{ Annual GW } & Annual Land & 2.4 & 0.1 & 1.7 & 0.4 & 1.7 & 0.4 & 2.4 & 2.5 & 5.3 & 8.4 & 10.0 & 5.2 & 6.8 & 13.1 & 1.1 & 8.5 & 3.7 \\
\hline & Annual Offs & 0.0 & 0.0 & 0.0 & 0.0 & 0.0 & 0.0 & 0.0 & 0.0 & 0.0 & 0.0 & 0.0 & 0.0 & 0.0 & 0.0 & 0.0 & 0.2 & 0.2 \\
\hline
\end{tabular}




\section{Wind Energy Project Trends in the United States since 2007}

Data on U.S. wind projects compiled by Lawrence Berkeley National Laboratory (LBNL) were used to investigate trends in U.S. wind plant technology, cost and performance. Appendix 6-A describes the data presented in this report including statistics describing the portion of installed capacity represented by the available data. This historical trends analysis focuses on "utilityscale" wind projects, defined here as projects that equal or exceed $1 \mathrm{MW}$ in capacity, utilizing turbines equal to or greater than $1 \mathrm{MW}$ in capacity, and selling electricity to the grid rather than offsetting electricity demand for an end-use customer (i.e. "behind the meter" installations). Nearly all of the installed U.S. wind capacity illustrated in Figure 6-1 meets this definition. The LBNL data provided information on project and turbine trends (project size, turbine size, rotor diameter, etc.), capital investment, and wind plant performance. Additional data sources were required for operations and maintenance expenditures and financing trends, as described in subsequent sections.

\section{Project and Turbine Features}

Wind project size has varied in the recent past, with no clear direction in trends. At the same time, U.S. wind projects continue to use larger turbines in terms of nameplate capacity, rotor diameter, and hub height. Figures 6-2 through 6-6 illustrate these trends from 2007 through 2012. A box and whiskers format is used to represent the projects or turbines that achieved commercial operation in the United States in a given year including the median (horizontal line), average (diamond), $25^{\text {th }}$ to $75^{\text {th }}$ percentile (box), and minimum and maximum (whiskers).

Although the range of project size is large, the majority of projects are about 25-150 MW throughout the time period of analysis (Figure 6-2). Research shows that economies of scale exist for larger projects, but this is especially the case for projects up to 50-100 MW in size (Wiser and Bolinger 2014), and project developers tend to portion the largest projects into phases that are built over a number of years.

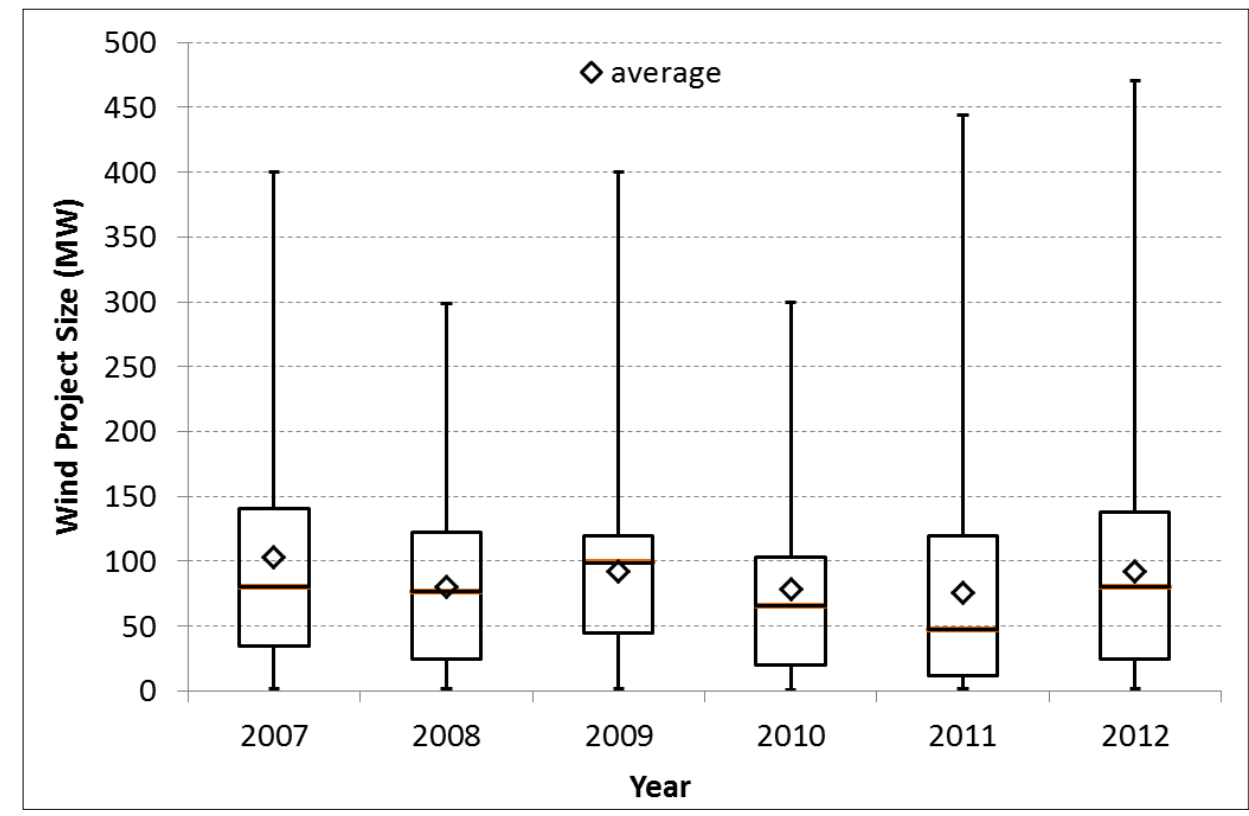

Figure 6-2. Wind project size trends from 2007 to 2012 
In 2007, wind turbines rated from 1.5 MW to 1.8 MW were prevalent. From 2007 to 2010, GE maintained significant market share with its 1.5 MW turbine (Wiser and Bolinger, 2014). Additional turbine offerings from other manufacturers, combined with higher capacity GE turbines in 2011 and 2012, have pushed the median upward while also broadening the range of turbine capacity installed in the United States (Figure 6-3).

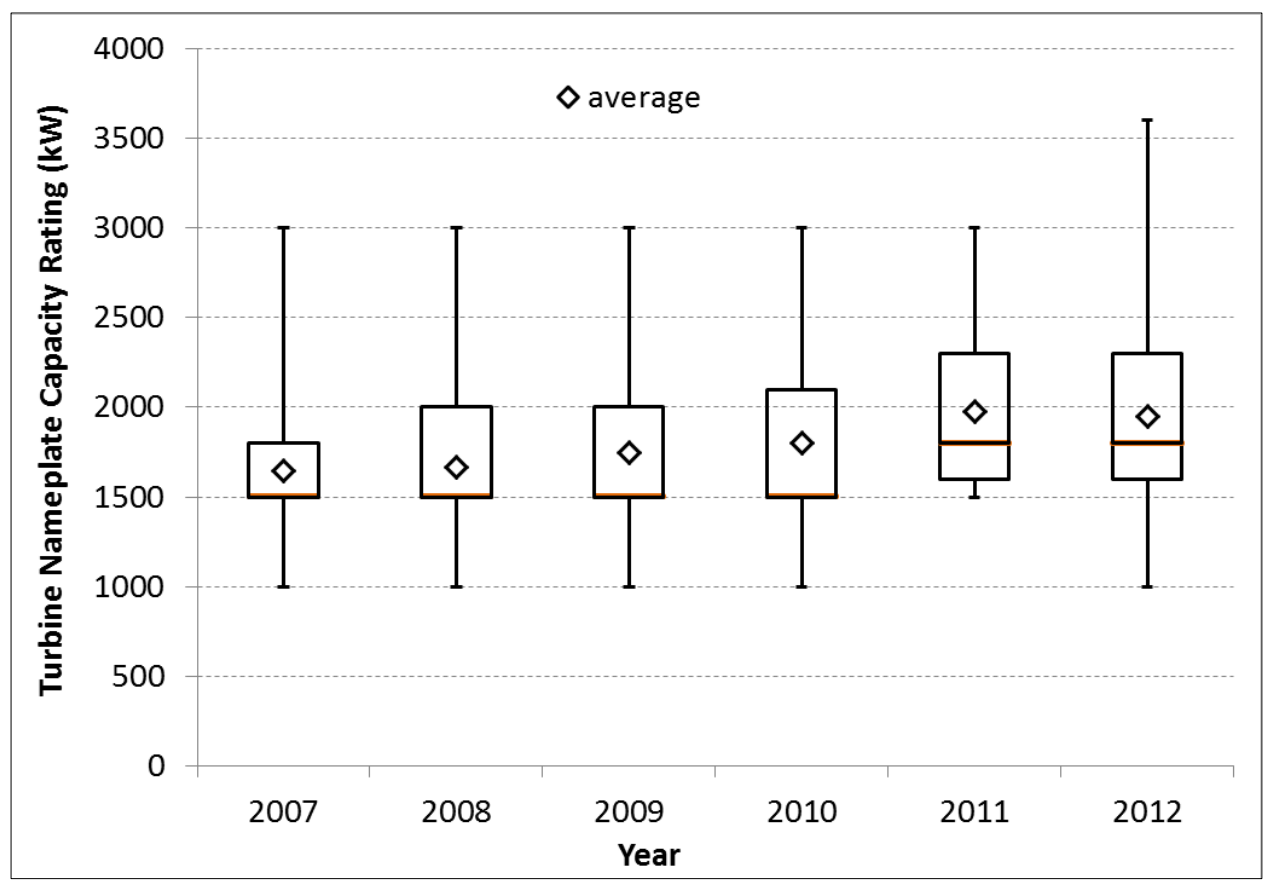

Figure 6-3. Wind turbine nameplate rating trends from 2007 to 2012

Along with the increase in turbine nameplate capacity, rotor diameter also increased from an average of about $80 \mathrm{~m}$ in 2007 to approximately $95 \mathrm{~m}$ in 2012 (Figure 6-4). 


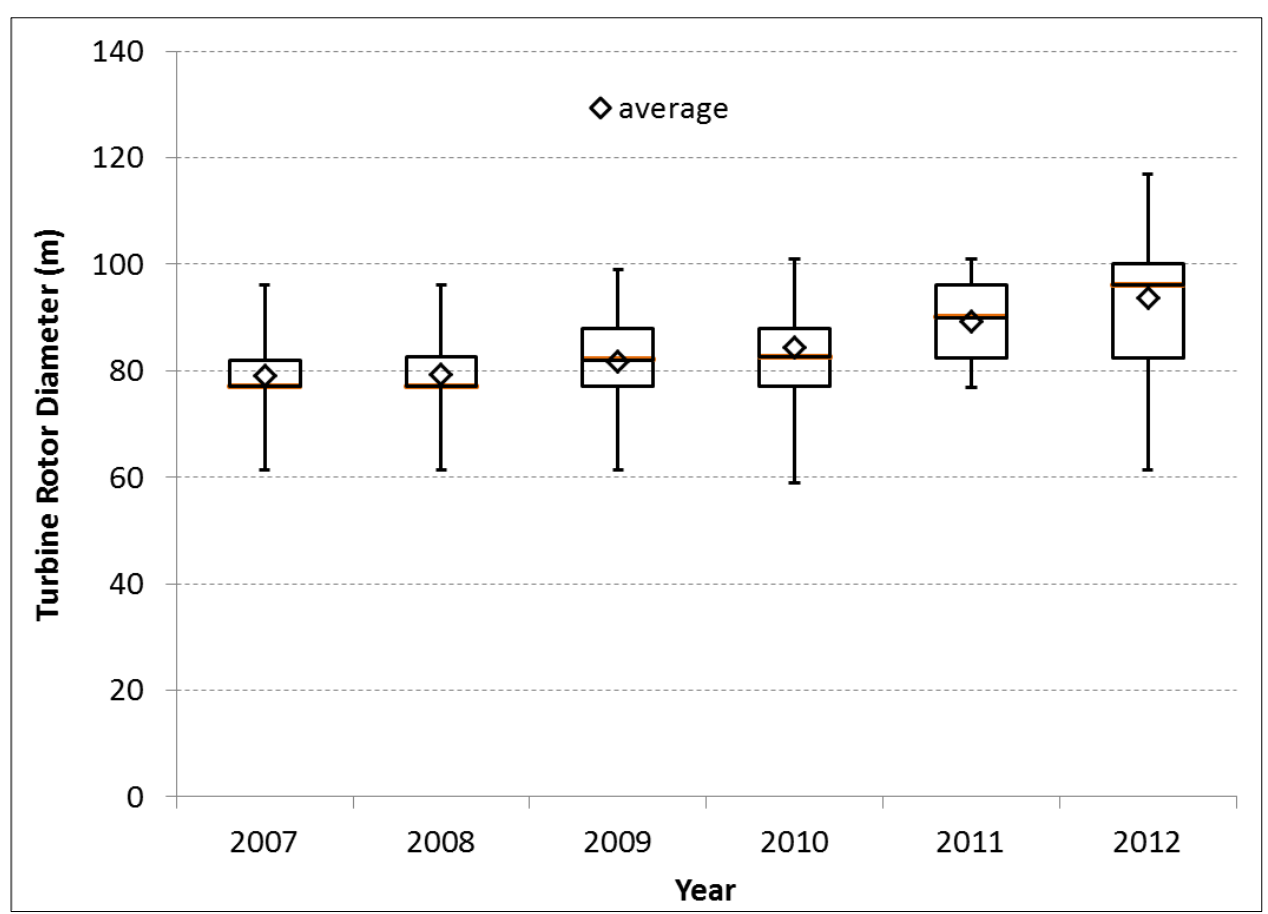

Figure 6-4. Wind turbine rotor diameter trends from 2007 to 2012

Although both turbine capacity and rotor diameter have trended upward, rotor diameter has increased at a relatively greater rate than nameplate capacity. This trend is reflected in the turbine "specific power," defined as the turbine nameplate capacity rating divided by the rotor swept area $\left(\mathrm{W} / \mathrm{m}^{2}\right)$. Average turbine specific power has fallen from levels approaching $350 \mathrm{~W} / \mathrm{m}^{2}$ to levels below $300 \mathrm{~W} / \mathrm{m}^{2}$ from 2007 to 2012. A lower specific power indicates that more wind energy can be extracted for a given generator size, thereby boosting capacity factors, all else being equal. Figure 6-5 illustrates the clear trend toward lower specific power machines in the United States over this period, as well as a broadening in the range of specific power, indicating that a more diverse set of turbine types have been installed in the United States in recent years.

Contrasting the trends in machine rating and rotor diameter, hub heights have remained relatively static from 2007 to 2012, with the 80-m height dominating. In 2012, there appears to be the beginning of a trend toward taller towers, but additional data and market observation are needed to determine whether this trend will continue. In most areas of the country, a higher hub height would yield increased energy capture, but the relative change in energy capture, transportation and logistics challenges, other cost drivers and regulatory policy may limit the size and tower height of land-based turbines. For instance, projects taller than $152 \mathrm{~m}$ (hub height plus blade length) must demonstrate that they do not interfere with military and civilian aviation. 


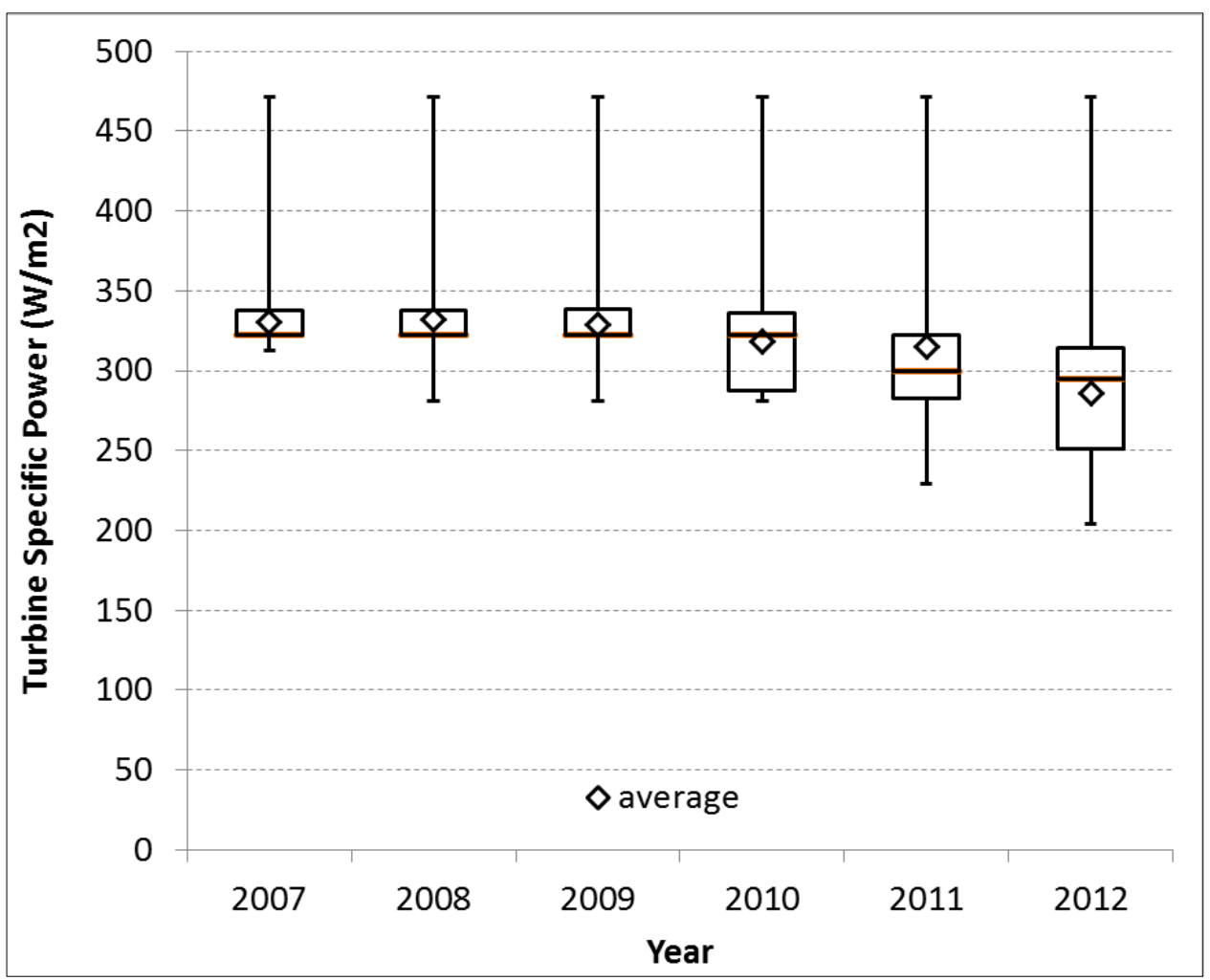

Figure 6-5. Wind turbine specific power trends from 2007 to 2012

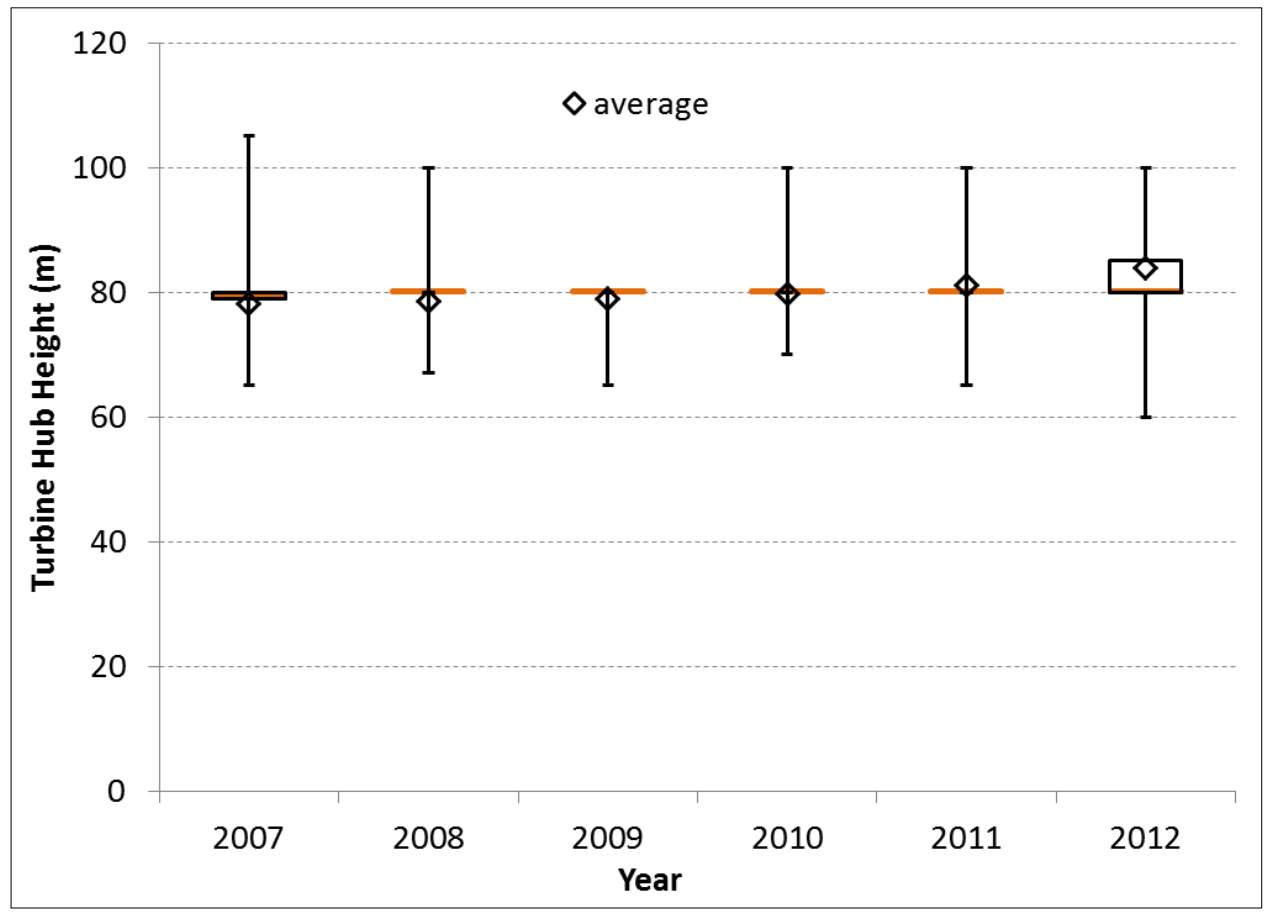

Figure 6-6. Wind turbine hub height trends from 2007 to 2012 
A final indicator of the changing turbine technology mix in the U.S. fleet is illustrated in Figure 6-7. The International Electro-Technical Commission (IEC) classification for a wind turbine is governed, in part, by the annual average wind speed for the turbine design. In general, Class I turbines are designed for higher annual average wind speeds than Class III turbines. Also, Class I turbines tend to have higher specific power than Class III turbines. With site-specific analysis of wind speeds and turbulence levels correlated with wind turbine load conditions, a wide range of wind turbine characteristics may be deemed suitable for a given site. As illustrated in Figure 6-7, Class III machines have markedly increased in market share since 2007, while the market share of Class I machines has declined.

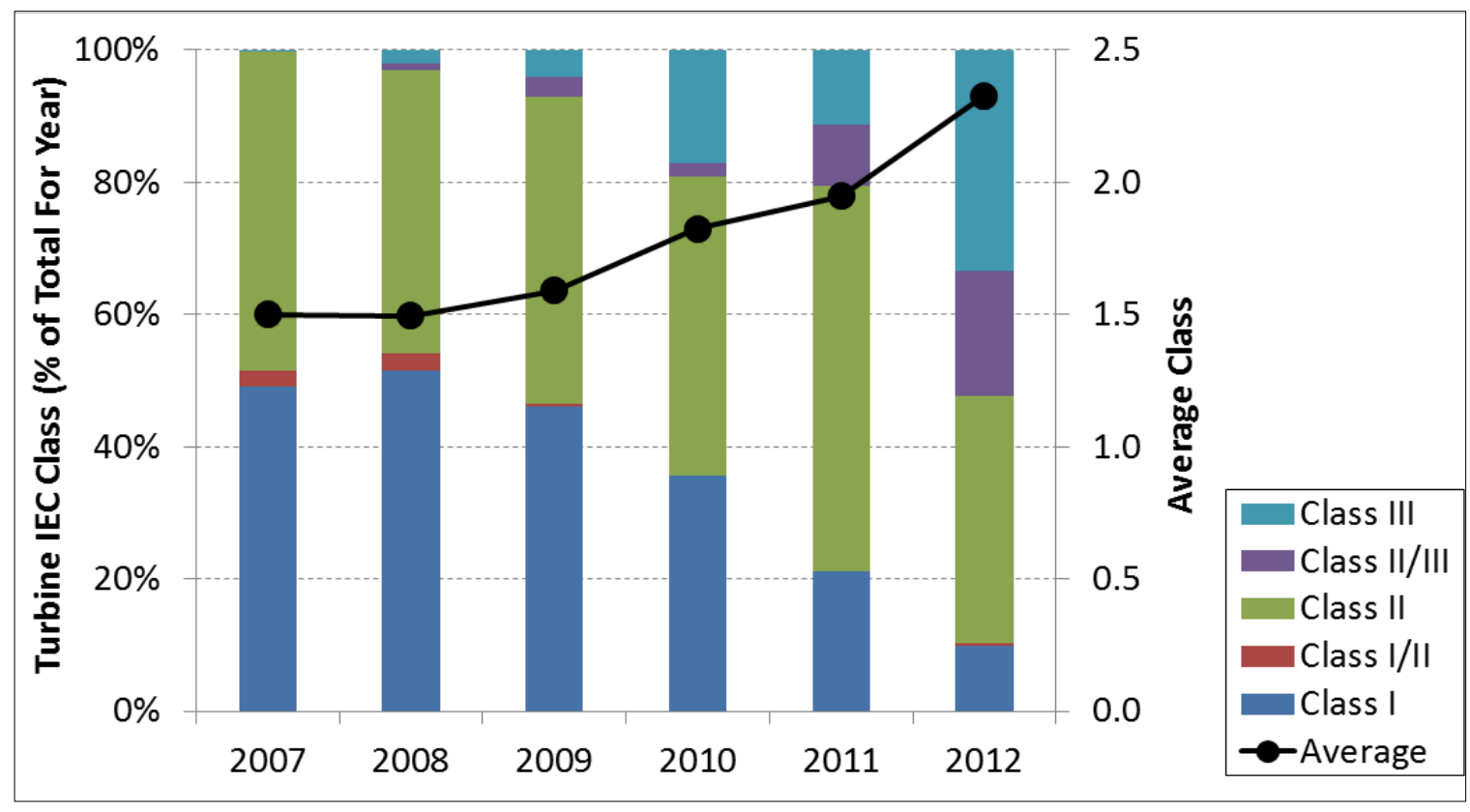

Figure 6-7. Proportion of turbines by IEC class installed from 2007 to 2012

\section{Project Performance}

Turbines with lower specific power will, all else being equal, yield higher levels of performance in terms of capacity factors or full-load hours. Despite the observed trend toward lower specific power turbines in the United States, project performance in terms of full-load hours and capacity factors has not similarly increased across the full data sample (Figure 6-8). This is primarily because the average wind speed where wind power projects have been installed has declined over time (Figure 6-9), offsetting the expected increase in performance associated with declines in specific power. Factors that may influence wind development in lower wind resource areas include proximity to markets, and siting and transmission constraints in higher wind resource areas. The fact that wind developers have had access to an investment tax credit (and, for a period, a cash grant) since 2009 that does not depend on production may have also made less energetic sites more desirable than they would have been with a production-based tax incentive.

In Figure 6-8, wind plant performance is represented in part as full-load hours, or the "equivalent" number of hours in a year when the wind plant is producing electricity at rated capacity. Capacity factor measures the same basic characteristic, but divides the full-load hours 
by the number of hours in a year. In the United States, virtually all electricity generation facilities are required to submit monthly electricity production totals to the Energy Information Administration, with similar data often also collected by the Federal Energy Regulatory Commission. These data are incorporated into the LBNL dataset, with most U.S. installed wind capacity represented (see Appendix 6-A for sample size definitions). These reported data represent electricity delivered to the grid, and so are affected by curtailment, electrical and aerodynamic losses within the wind plant, turbine downtime, and other factors. Curtailment due to forced or economic reasons reduces plant output from that theoretically available; on average, annual capacity factors would have been $0.5-2.0$ percentage points higher from 2008 to 2013 absent curtailment in the regions where it is tracked and reported (Wiser and Bolinger 2014). Figure 6-8 shows the annual performance of wind projects operating in 2013 based on their commercial operation date. During 2013, all wind plants installed in 2007 produced a generation-weighted average of about 3,000 full-load hours. Wind plants installed in 2012 and operating in 2013 produced a generation-weighted average just under 3,000 full-load hours. NextEra Energy Resources, in its quarterly earnings reports, estimates an annual wind resource index for the United States as a whole, with a value in 2013 of $98 \%$. This index is intended to represent average nationwide wind resource variation from year to year and is used to reduce the influence of inter-annual wind resource variation on energy production comparisons. To estimate full-load hours in a typical wind resource year, the generation-weighted average full-load hours are also shown adjusted upward by 1.02 (or 1/0.98).

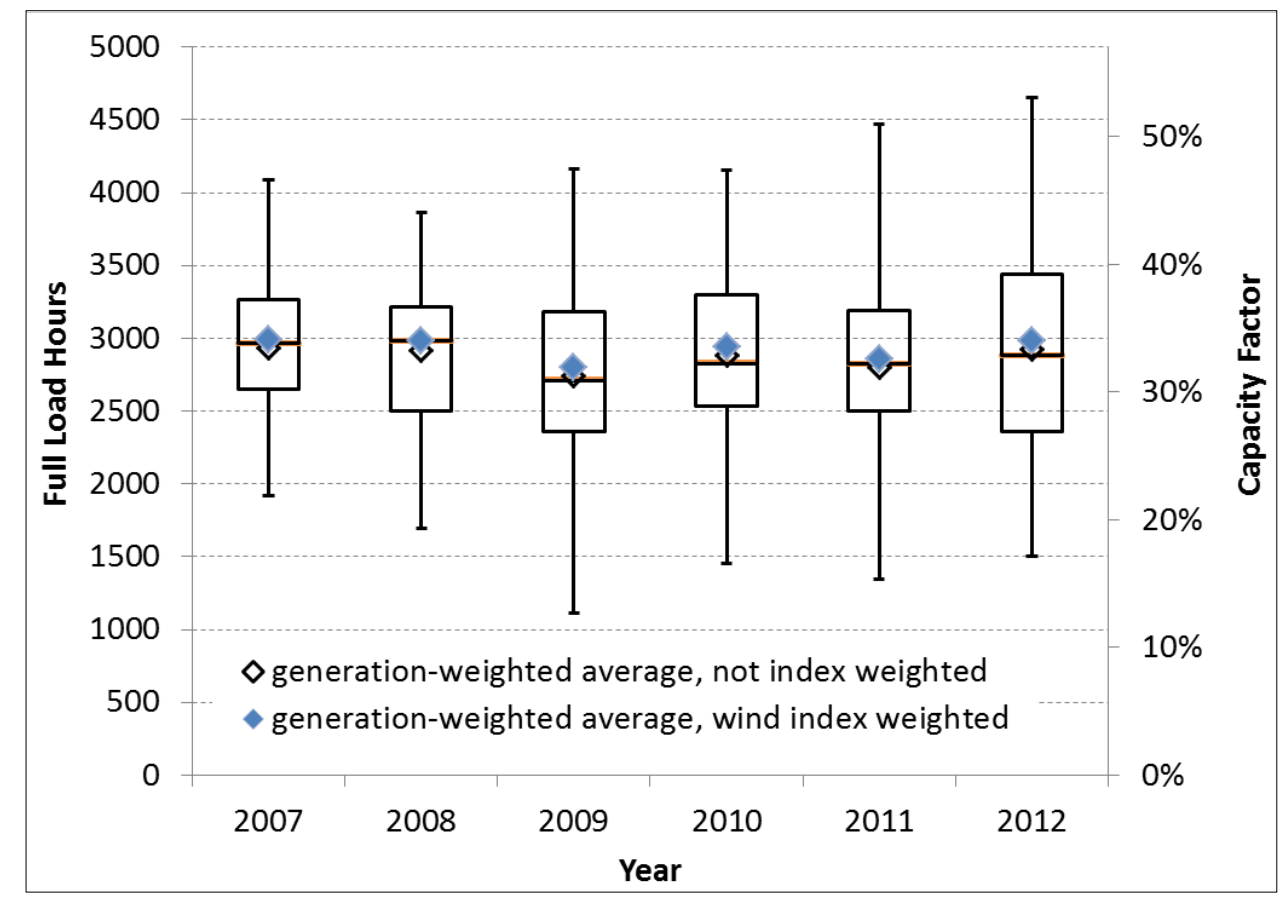

Figure 6-8. Full-load hours and capacity factors for projects installed from 2007 to 2012, operating in 2013

In Figure 6-9, annual average wind speed for all turbines represented in the LBNL database was extracted from modeled wind resource estimates created by AWS Truepower (AWS Truepower, 2009). The modeled wind speed data are at an $80 \mathrm{~m}$ height above ground level and are not adjusted to accommodate the effective decrement of wind power generation associated with 
lower air density at higher elevation. The wind resource estimates are provided on a $20 \mathrm{~km}$ by 20 $\mathrm{km}$ grid, with each turbine associated with the annual average wind speed of the grid in which the turbine is located. This coarse wind speed grid is likely to result in lower estimated annual average wind speed for a given turbine than actual wind speeds. In other words, turbines would likely be placed in locations within each $20 \mathrm{~km}$ by $20 \mathrm{~km}$ grid cell with higher wind speeds than the average across the grid area. Although this wind speed estimate may not accurately reflect the actual turbine location, the general trend over time should be consistent with actual annual average wind speed trends. The trend toward locations with lower annual average wind speeds as shown in Figure 6-9 is therefore credible, but one must be careful to not place too much emphasis on the absolute magnitude of the wind speeds shown.

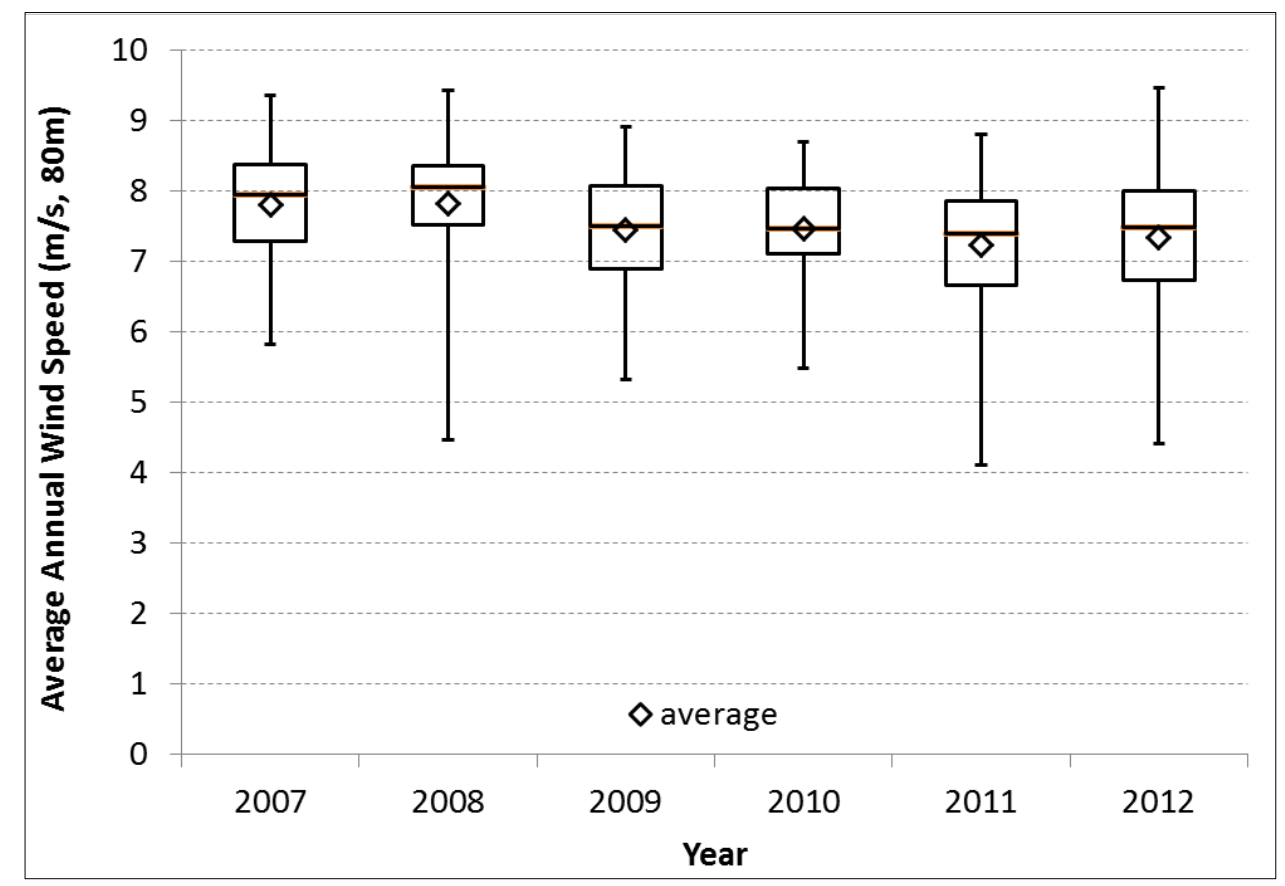

Figure 6-9. Annual average wind speed for projects installed from 2007 to 2012

\section{Investment Costs}

From 2007 to 2012, average project investment costs increased, and subsequently declined (Figure 6-10). Turbine prices first increased, due to the dollar/euro exchange rate; increased materials, energy, and labor input prices; a tight turbine market; increased costs for turbine warranty provisions; and an up-scaling of turbine size, including hub height and rotor diameter (Bolinger and Wiser, 2011). Since 2008, however, wind turbine prices have declined substantially, reflecting a reversal of some of the previously mentioned underlying trends that had earlier pushed prices higher as well as increased competition among manufacturers and a shift to a buyer's market (Wiser and Bolinger, 2014). Whereas turbine prices peaked in 2008/2009, project-level installed costs appear to have peaked in 2009/2010 due to a lag between when turbines are purchased and when they are installed. Regional differences in average project costs are apparent and may occur due to variations in development costs, transportation costs, siting and permitting requirements and timeframes, and other balance-of-plant and construction expenditures, as well as variations in the turbines deployed in different regions (e.g., use of low- 
wind-speed technology in regions with lesser wind resources). Though not shown in the figure, average wind project costs decreased further in 2013 (Wiser and Bolinger, 2014).

The LBNL dataset on project-level investment costs derives from multiple sources, but generally represents the total investment required to bring a plant to commercial operation including the plant equipment, installation, grid connection, and financing during the construction period. Although the specific data sources and thereby the data quality varies, in aggregate these data provide a useful representation of investment costs in the United States

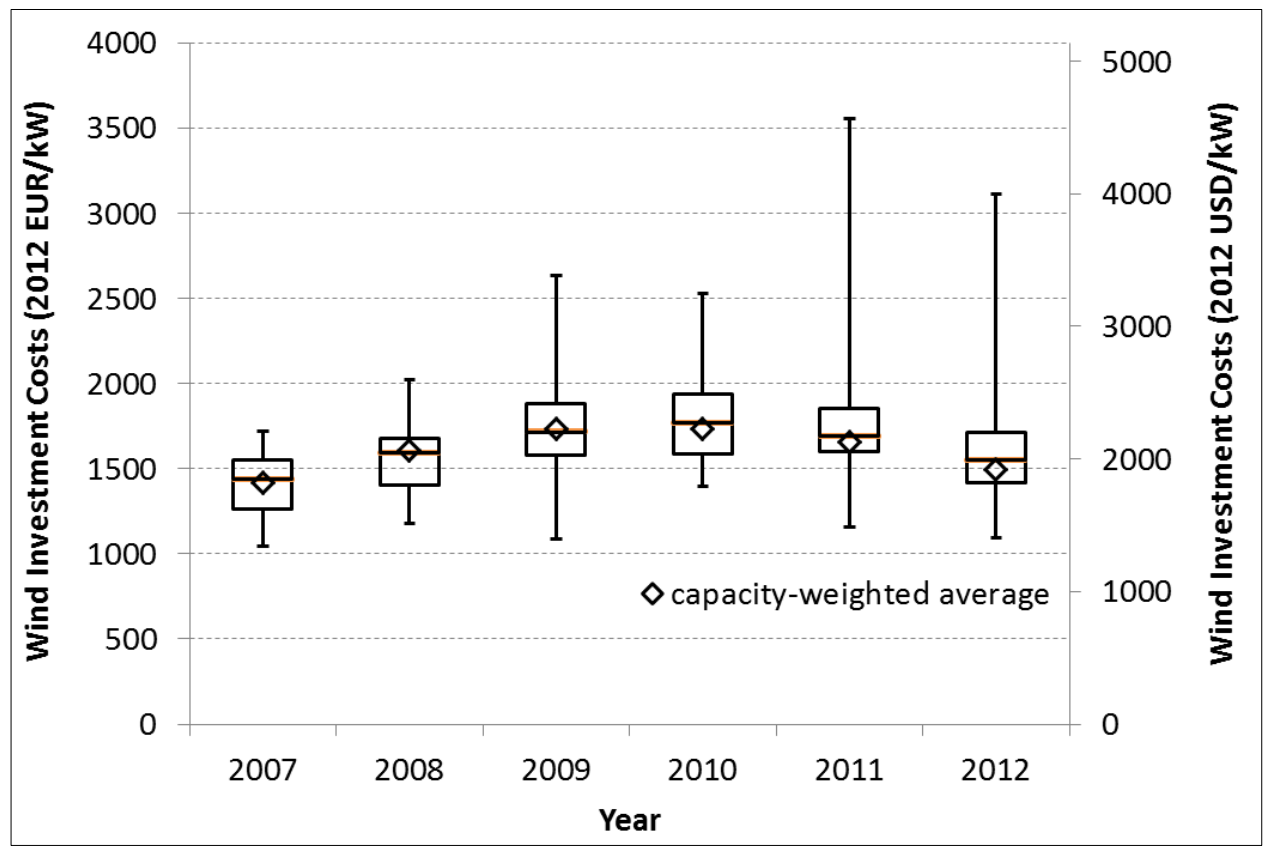

Figure 6-10. Investment costs for projects installed from 2007 to 2012

\section{Operations and Maintenance Costs}

O\&M expenses typically include land-lease costs, operation and maintenance wages and materials, and component replacement costs - all expenses required to operate a wind plant. O\&M costs are generally expressed as fixed O\&M, which includes known costs (e.g., scheduled maintenance, rent, taxes, utilities, or insurance payments) that typically don't change depending on how much electricity is generated, and as variable O\&M, which includes unplanned maintenance and other costs that may vary throughout the project life depending on how much the turbine operates. For simplicity, this analysis converts all operating expenses to a fixed O\&M term of $\$ / \mathrm{kW} / \mathrm{yr}$.

Publicly available market data on actual project-level O\&M costs are not widely available in the United States, and those data that are available often show mixed and unclear trends (Wiser and Bolinger 2014; Lantz 2013). Overall, operations costs tend to be elevated during the first 12-24 month "teething" period and during the later years of the project's life with relatively lower costs in the interim (Hill et al., 2008). Due to the lack of available market data, especially over a long time period, for this analysis a value of $\$ 50 / \mathrm{kW} / \mathrm{yr}$ was assumed for average annual O\&M 
expenditures over the financial life of the project, 20 years. ${ }^{51}$ Although this number has relatively high uncertainty, given current data, it is assumed to be representative of costs in the United States. There is insufficient data to indicate clearly whether O\&M expenditures have changed over the period from 2007 to 2012. As such, all subsequent modeling assumes O\&M expenditures of $\$ 50 / \mathrm{kW} / \mathrm{yr}$ in real terms in $2012 \mathrm{U}$.S. dollars throughout the period from 2007 to 2012.

\section{Financing Costs}

To obtain the full benefit of the production tax credit and accelerated depreciation, project owners must have a sufficient tax liability to offset or must instead rely on outside equity investors that choose to invest and have the requisite tax liability. Project level financing details are not typically publicly available. As such, an estimate of the WACC for projects installed from 2007 to 2012 was developed based on generic historical data from BNEF on the cost of third-party tax equity and project-level 15-year term debt, as well as LBNL estimates of the cost of sponsor equity. Representative project level capital structures are derived from financial modeling; these determine the mix of the three capital sources, and hence the WACC, under various financing structures. The min and max WACC shown in Figure 6-11 reflect the various financing structures that are relevant in each year. The average WACC is based on LBNL estimates of the percentage of installed capacity utilizing the various financing structures. All values are presented in after-tax, nominal terms. ${ }^{52}$ As shown, the WACC increased from 2007 to 2009 , in part as a result of the financial crisis, dropped in 2010, and has risen slightly since then.

Over the relevant period from 2007 to 2012, there have been five primary financing structures used to varying degrees for the purpose of capturing tax benefits:

- a "partnership flip" structure in which the project sponsor partners with a tax equity investor to monetize the tax benefits (involves a mix of sponsor equity and tax equity)

- a basic "self-sheltering" structure in which the sponsor has sufficient tax liability to use the tax benefits on its own (involves a mix of sponsor equity and debt)

- a more-aggressive "self-sheltering" structure in which the sponsor is not only able to use tax benefits on its own, but also borrows against them by pledging equally sized cash infusions to service debt as needed (involves a mix of sponsor equity and debt, with greater leverage)

- from 2009 to 2012 only, a structure in which the sponsor elects the Section 1603 30\% cash grant in lieu of the PTC, and partners with a tax equity investor to monetize depreciation benefits (involves a mix of sponsor equity and tax equity)

- from 2009 to 2012 only, a structure in which the sponsor elects the Section 1603 30\% cash grant in lieu of the PTC, and has sufficient tax liability to use the depreciation benefits on its own (involves a mix of sponsor equity and debt).

\footnotetext{
${ }^{51}$ Represented in real terms. Cash flow estimates of future expenditures in specific years along with inflation impacts are not estimated directly.

52 Subsequent LCOE calculations are made in real terms assuming an inflation rate of $2 \%$.
} 
The "national average" numbers and ranges shown in Figure 6-11 and Table 6-2 reflect a blend of these five financing structures, based on LBNL estimates of their relative use in the market in each period. The historical cost of third-party tax equity and project-level 15 -year term debt come from BNEF, while the cost of sponsor equity is estimated by LBNL. The "2014 Interior" column in Table 6-2 reflects the more-aggressive "self-sheltering" structure described in the third bullet above, in which the sponsor not only uses the tax benefits internally, but also borrows against them to boost leverage.

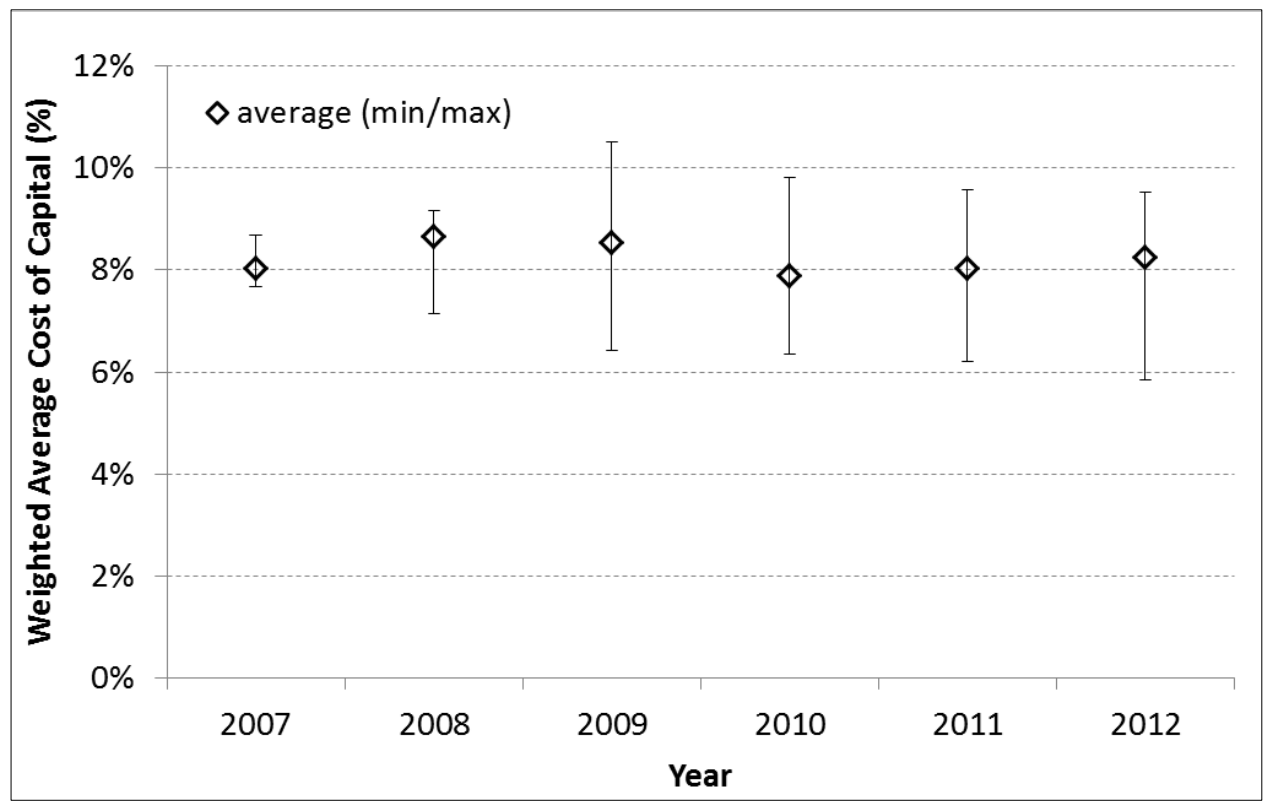

Figure 6-11. Weighted Average Cost of Capital for projects installed from 2007 to 2012

Table 6-2. Example Wind Energy Project Financing Terms in the United States

\begin{tabular}{|c|c|c|c|c|}
\hline Financing Ass umptions & Unit & $\begin{array}{c}\mathbf{2 0 0 8} \text { National } \\
\text { Average }\end{array}$ & $\begin{array}{c}\text { 2012 National } \\
\text { Average }\end{array}$ & 2014 Interior \\
\hline After-Tax Tax Equity IRR & $\%$ & $7 \%$ & $8 \%$ & N/A \\
\hline After-Tax Sponsor Equity IRR & $\%$ & $12 \%$ & $12 \%$ & $12 \%$ \\
\hline After-Tax Debt Cost & $\%$ & $4 \%$ & $4 \%$ & $4 \%$ \\
\hline Tax Equity Share & $\%$ & $42 \%$ & $38 \%$ & $0 \%$ \\
\hline Sponsor Equity Share & $\%$ & $41 \%$ & $35 \%$ & $43 \%$ \\
\hline Debt Share & $\%$ & $16 \%$ & $28 \%$ & $57 \%$ \\
\hline Loan Duration & years & 15 & 15 & 15 \\
\hline Corporate tax rate & $\%$ & 40.2 & 40.2 & 40.2 \\
\hline FX rate & USD/EUR & 1.28 & 1.28 & 1.28 \\
\hline WACC (after-tax, nominal / & $\%$ & $8.7 \% / 6.6 \%$ & $8.3 \% / 6.2 \%$ & $7.2 \% / 5.1 \%$ \\
\hline after-tax real) & & & & \\
\hline
\end{tabular}




\section{Cost of Wind Energy Generation in the United States in 2008 and 2012}

\section{Representative Wind Energy Projects in 2008 and 2012}

The historical trends presented earlier provide insight into the change in technology, investment cost, operation cost, energy production and financing observed in the United States from 2007 to 2012. Altogether, these parameters represent the elements needed to calculate the LCOE_or the cost per unit of energy produced to build and operate a wind plant for its financial life: 20 years. In Schwabe et al. (2011), similar data were used to represent typical wind plant characteristics and cost in 2007 and 2008. In the present analysis, a comparison is made between the cost of energy in 2008 and 2012. A hypothetical representation of a project likely to be installed in 2014 is also included to provide a directional indicator of cost of energy.

For 2008 and for 2012, the LCOE of a "National Average" wind plant is estimated. For these National Average wind plants, values corresponding to the averages shown for 2008 and 2012 in the historical trends section of this report were used in the cash flow model to estimate LCOE.

Technology trends described earlier are generally expected to continue through 2013 and 2014 resulting in turbines with even lower specific power. It is anticipated that these turbines will be installed in a wider variety of sites, not just lower-wind speed locations. The 2014 Interior project, on the other hand, reflects the use of a wind turbine with low specific power in a relatively high wind speed site similar to those found in the Interior region of the United States with attractive financing. This type of project illustrates the conditions that have led to some of the low contracted prices or PPAs evident in the United States in 2012 and extending into 2013 (Wiser and Bolinger, 2014).

\section{Model Input Assumptions}

The wind project features for the 2008 and 2012 National Average and 2014 Interior projects are shown in Table 6-3. The National Average projects are represented by the average values for 2008 and for 2012 illustrated in the previous historic trends section, including the turbine size, rotor diameter, hub height, average wind speed, power production, and investment costs. As noted earlier, due to lack of data, no variation in O\&M costs over the time period is represented. Decommissioning costs are not typically identified for U.S. projects. As discussed earlier, average wind turbines in 2012 are larger than in 2008, and the investment cost is slightly lower. The expected increase in energy capture from the larger turbines for the National Average project is mostly offset by the observed tendency to locate turbines in lower wind speed sites. The 2014 Interior project, meanwhile, is an example of turbine and project characteristics representative of projects achieving low PPA prices in 2012 and 2013 to be operational in 2014 based on industry observations. ${ }^{53}$ For comparison the characteristics of the representative U.S. wind plant in 2008 described in Schwabe et al. (2011) are included ${ }^{54}$; this 2008 National

\footnotetext{
${ }^{53}$ The wind turbine size, rotor diameter, hub height, annual average wind speed, and investment cost were selected based on underlying data for Wiser and Bolinger (2014) for projects in the Interior region of the United States. The production estimate was determined using a generic wind power curve, assumed losses, and annual average wind speed, and the estimated full load hours are consistent with estimates reported in recent PPA applications. The lower-cost financing assumption reflects balance-sheet financing available to a sub-set of wind developers in the United States.

${ }^{54}$ Values have been converted to 2012 US dollars using the methodology defined earlier.
} 
Average wind plant is revised to provide a consistent estimate with the 2012 analysis, primarily in the representation of O\&M costs and project financing.

Project finance assumptions for the 2008 and 2012 National Average and 2014 Interior projects are shown in Table 6-3, and the finance assumptions for the 2008 project described in Schwabe et al., (2009) are included for reference. For the modeling analysis, an assumption of $100 \%$ equity with required return on equity equivalent to the WACC is implemented in order to represent a mix of debt and equity consistent with that observed in the United States as illustrated in Figure 6-11 $1^{55}$ (Appendix 1 describes the modeling approach in greater detail). The real WACC is estimated to have dropped from a national average of $6.5 \%$ in 2008 to a national average of $6.1 \%$ in 2012 . The 2014 Interior project is assumed to have access to lower-cost financing at $4.9 \%$, substantially driving down the project LCOE.

Table 6-3. Wind Energy Project Features in the United States

\begin{tabular}{|l|l|c|c|c|c||}
\hline Characteristics & Unit & $\begin{array}{c}\text { 2008 (Schwabe et al., } \\
\mathbf{2 0 1 1}\end{array}$ & $\begin{array}{c}\text { 2008 National } \\
\text { Average }\end{array}$ & $\begin{array}{c}\text { 2012 National } \\
\text { Average }\end{array}$ & 2014 Interior \\
\hline Unit size & $\mathrm{MW}$ & 1.67 & 1.67 & 1.95 & 1.62 \\
\hline Number of turbines & $\#$ & 50 & 50 & 50 & 50 \\
\hline Rotor diameter/ Hub height & $\mathrm{m} / \mathrm{m}$ & $77 / 65$ & $79 / 78$ & $94 / 84$ & $100 / 80$ \\
\hline Annual average wind speed at hub height & $\mathrm{m} / \mathrm{s}$ & $\mathrm{n} / \mathrm{a}$ & 7.8 & 7.4 & 8.5 \\
\hline Production & full load hours & 3,066 & 2,979 & 2,984 & 4,139 \\
\hline Economic life & years & 20 & 20 & 20 & 20 \\
\hline Investment costs & $\$_{2012} / \mathrm{kW}$ & 2,027 & 2,065 & 1,919 & 1,750 \\
\hline & $\epsilon_{2012} / \mathrm{kW}$ & 1,577 & 1,607 & 1,494 & 1,362 \\
\hline O\&M costs (total, expressed in fixed-costs terms) & $\$_{2012} / \mathrm{kW}-\mathrm{yr}$ & 33 & 50 & 50 & 50 \\
\hline Decommission costs & $\epsilon_{2012} / \mathrm{kW}-\mathrm{yr}$ & 26 & 39 & 39 & 39 \\
\hline WACC (nominal/ real) & $€ c t / \mathrm{kWh}$ & 0 & 0 & 0 & 0 \\
\hline Corporate tax rate & $\%$ & $9.65 / 7.5$ & $8.7 / 6.6$ & $8.3 / 6.2$ & $7.2 / 5.1$ \\
\hline
\end{tabular}

In the United States, wind projects generally negotiate PPAs, or long-term (typically 20-year) contracts for the sale of electricity at a set price. ${ }^{56}$ The market electricity price shown in Table 65 represents a range of average, levelized PPA prices for contracts signed the year prior as reported in Wiser and Bolinger (2014) for the National Average projects. The range of PPA prices associated with the 2014 Interior project represent average, levelized PPA prices for the Interior region of the country from 2011 through 2013. The primary policy instruments available in the United States are summarized in Table 6-4 including the PTC which is valued at $\$ 0.022 / \mathrm{kWh}$ and accelerated depreciation which allows depreciation of the capital investment over a six-year period. ${ }^{57}$

\footnotetext{
55 Nominal WACC was converted to a real WACC with an assumption of a $2 \%$ inflation rate.

${ }^{56}$ Many contracts include provisions for inflation.

${ }^{57}$ Because some portion of the total capital investment is generally not depreciable over the six-year period (e.g., grid connection costs), the depreciable amount is restricted to $95 \%$ of the total capital investment in the modeling analysis.
} 
Table 6-4. Wind Energy Policy and Revenue Incentives in the United States

\begin{tabular}{|c|c|c|c|c|c|}
\hline Policy or Revenue Parameters & Unit & $\begin{array}{c}2008 \text { (Schwabe et al., } \\
\text { 2011) }\end{array}$ & $\begin{array}{c}2008 \text { National } \\
\text { Average }\end{array}$ & $\begin{array}{l}2012 \text { National } \\
\text { Average }\end{array}$ & 2014 Interior \\
\hline Market Price Electricity & $\$_{2012} / \mathrm{kWh}$ & 0.061 & $0.042-0.069$ & $0.034-0.074$ & $0.022-0.035$ \\
\hline FIT revenue & $\$_{2012} / \mathrm{kWh}$ & N/A & N/A & N/A & N/A \\
\hline FIT policy period & years & N/A & N/A & N/A & N/A \\
\hline Upfront tax-based subsidy before tax & $\%$ & 0 & 0 & 0 & 0 \\
\hline Production-based tax credits & $\$_{2012} / \mathrm{kWh}$ & 0.022 & 0.022 & 0.022 & 0.022 \\
\hline Production-based tax credit policy period & years & 10 & 10 & 10 & 10 \\
\hline Accelerated Depreciation period & years & 6 & 6 & 6 & 6 \\
\hline Reactive power bonus & $\$_{2012} / \mathrm{kWh}$ & 0 & 0 & 0 & 0 \\
\hline Low voltage ride through bonus & $\$_{2012} / \mathrm{kWh}$ & 0 & 0 & 0 & 0 \\
\hline Market certificates & $\$ 2012 / \mathrm{kWh}$ & $\begin{array}{l}\text { Included in } \\
\text { electricity price }\end{array}$ & $\begin{array}{l}\text { Included in } \\
\text { electricity price }\end{array}$ & $\begin{array}{l}\text { Included in } \\
\text { electricity price }\end{array}$ & $\begin{array}{l}\text { Included in } \\
\text { electricity price }\end{array}$ \\
\hline
\end{tabular}

\section{LCOE and Financial Gap}

The LCOE was calculated for each of projects defined in the previous section using the cash flow model developed for use in IEA Wind Task 26 (Schwabe et al., 2011). Appendix 1 describes the modeling approach. To represent the U.S. projects, investment costs, fixed O\&M costs, and production estimates are entered as defined in the tables above. Project finance assumptions are modeled using the WACC. An assumption of straight-line depreciation of 100\% of the capital investment provides a common basis for representing the cost of energy for each of the countries participating in IEA Wind Task 26. The LCOE for each of the projects is shown in Table 6-5.

Table 6-5. Wind Plant LCOE Summary with Policy and Revenue Components

\begin{tabular}{|c|l|c|c|c|c|}
\hline Model Estimate & Unit & $\begin{array}{c}2008 \text { (Schwabe et } \\
\text { al., 2011) }\end{array}$ & $\begin{array}{c}\text { 2008 National } \\
\text { Average }\end{array}$ & $\begin{array}{c}\text { 2012 National } \\
\text { Average }\end{array}$ & 2014 Interior \\
\hline Levelized cost of energy & $\left(\$_{2012} / \mathrm{MWh}\right)$ & 95.9 & 99.3 & 90.3 & 55.1 \\
\hline Levelized cost of energy & $\left(€_{2012} / \mathrm{MWh}\right)$ & 74.7 & 77.3 & 70.3 & 42.9 \\
\hline Value of policy & $\left(\$_{2012} / \mathrm{MWh}\right)$ & 35.3 & 34.6 & 32.9 & 27.7 \\
\hline Value of policy & $\left(€_{2012} / \mathrm{MWh}\right)$ & 27.5 & 27.0 & 25.6 & 21.5 \\
\hline Revenue Required & $\left(\$_{2012} / \mathrm{MWh}\right)$ & 60.6 & 64.6 & 57.4 & 27.4 \\
\hline Revenue Required & $\left(€_{2012} / \mathrm{MWh}\right)$ & 47.2 & 50.3 & 44.7 & 21.3 \\
\hline
\end{tabular}

The value of available policy instruments is represented by implementing six-year accelerated depreciation and the PTC in the cash flow model. The difference between the estimated LCOE and the "financial gap" value produced by the cash flow model represents the impact of these policy mechanisms. The estimated "financial gap" then reflects the required revenue that the wind project must obtain to satisfy the return on equity embedded in the WACC value. Figure 612 illustrates the relative contribution of the policy mechanism and the revenue required to offset the cost of building and operating the wind plant. The estimated revenue required portion for each of the representative projects as shown in Figure 6-12 falls within the range of market electricity prices associated with PPA prices for projects installed in 2008 and 2012 as shown in Table 6-5. This suggests that for these example 2008 and 2012 wind projects there is no financial gap between the cost of a wind plant, the policy support and the expected revenue. 


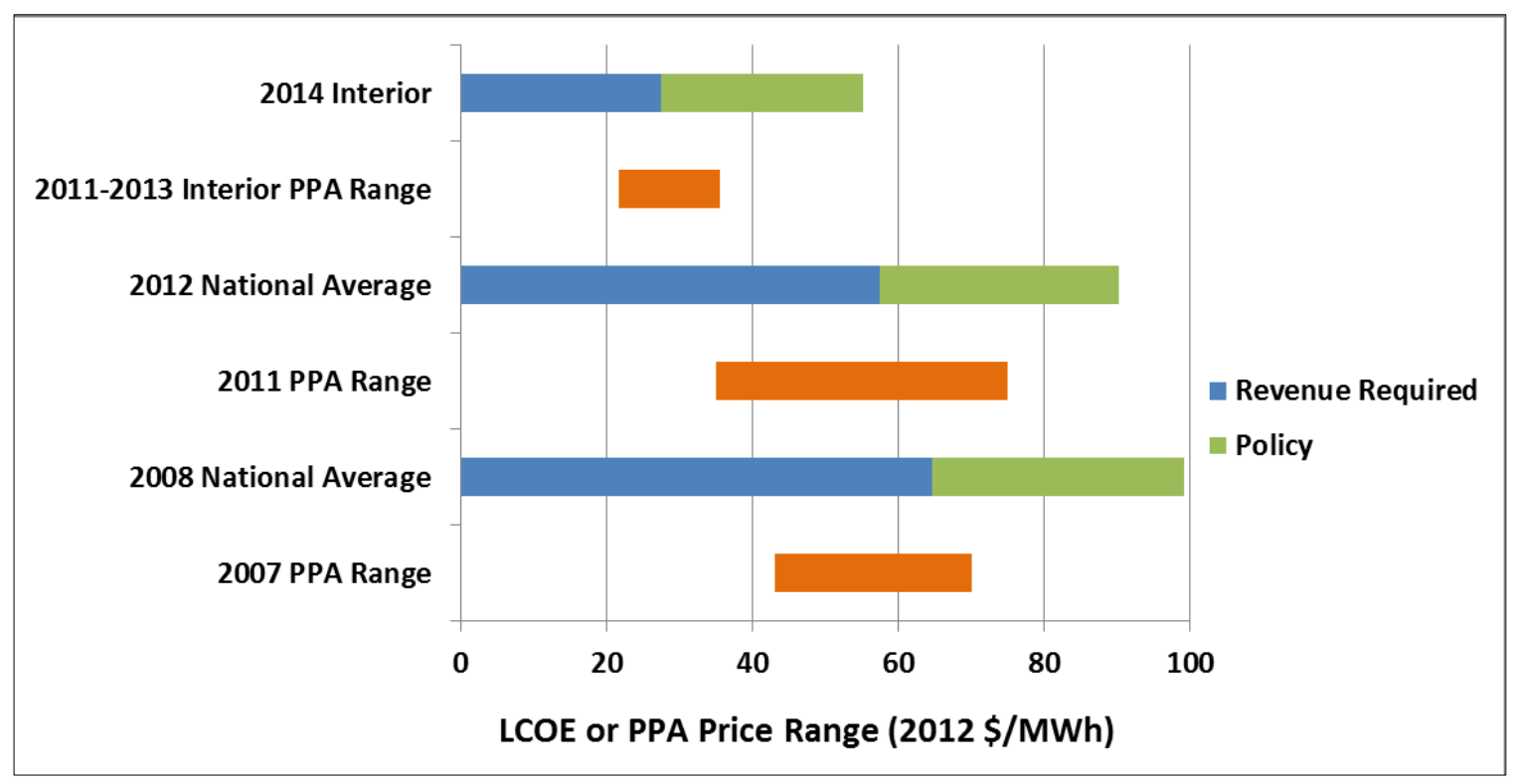

Figure 6-12. LCOE for 2008 and 2012 wind plants, including required revenue and policy contributions relative to PPA price ranges

\section{Summary of Wind Project Trends in United States}

From 2008 to 2012 several trends have combined to result in generally lower levelized cost of energy from $\$ 99 / \mathrm{MWh}$ to $\$ 90 / \mathrm{MWh}$. Larger turbines, especially in rotor diameter, have enabled greater energy capture for a given wind resource location while the required capital investment is slightly lower than that observed in 2008. In addition, wind project financing rates have declined even as tax-equity investors continued to play a prominent role from 2007 to 2012. At the same time, these trends have been partially offset by use of lower wind speed sites, at least through 2012. Nevertheless, a large number of wind projects have been installed in the United States and the wide range of wind resource available results in a broad range of market electricity prices (i.e., PPAs). Under favorable conditions, projects in 2012 were able to realize a levelized cost of energy at the level of $\$ 54 / \mathrm{MWh}$ or even lower.

Going forward, trends to larger turbines with lower specific power are likely to continue. Many projects in 2013 and planned for 2014 are located in the higher wind resource areas of the country suggesting a trend toward lower LCOE. This trend is supported by recently completed PPAs as low as $\$ 22 / \mathrm{MWh}$. Beyond 2016, in the absence of new policy actions such as the reinstatement of a PTC, market-based revenue will need to rise; based on these technology trends, however, wind plant cost of energy will remain a relatively low-cost generation source in the United States. 


\section{References for Chapter 6}

AWS TruePower (2009). Annual average wind speed $(\mathrm{m} / \mathrm{s})$ at $80 \mathrm{~m}$ hub height, modeled using AWS's mesoscale modeling system. Spatial resolution $2.5 \mathrm{~km}$, interpolated by AWS to a $200 \mathrm{~m}$ resolution. https://www.awstruepower.com/

Bloomberg New Energy Finance (Bloomberg NEF). 2014. Q1 2014 Wind Market Outlook. March 4, 2014.

Bolinger, M. and R. Wiser. 2011. Understanding Trends in Wind Turbine Prices Over the Past Decade. LBNL-5119E. Berkeley, California: Lawrence Berkeley National Laboratory.

Energy Information Administration (viewed October 13, 2014).

http://www.eia.gov/electricity/data/browser/

Hill, R.; Stinebaugh, J.; Briand, D.; Benjamin, A.; Linsday, J. (2008) Wind Turbine Reliability: A Database and Analysis Approach. 70 pp.; Sandia Report No. SAND2008-0983

Krey V., O. Masera, G. Blanford, T. Bruckner, R. Cooke, K. Fisher-Vanden, H. Haberl, E. Hertwich, E. Kriegler, D. Mueller, S. Paltsev, L. Price, S. Schlomer, D. Urge-Vorsatz, D. van Vuuren, and T. Zwickel, 2014: Annex II: Metrics \& Methodology. In: Climate Change 2014: Mitigation of Climate Change. Contribution of Working Group III to the Fifth Assessment Report of the Intergovernmental Panel on Climate Change [Edenhofer, O., R. Pichs-Madruga, Y. Sokona, E. Farahani, S. Kadner, K. Seyboth, A. Adler, I. Baum, S. Brunner, P. Eickemeier, B. Kriemann, J. Savolainen, S. Schlomer, C. von Stechow, T. Zwickel and J.C. Minx (eds.)]. Cambridge University Press, Cambridge, United Kingdom and New York, NY, USA.

Lantz, E. (2013). Operations Expenditures: Historical Trends and Continuing Challenges (Presentation). NREL (National Renewable Energy Laboratory). 20 pp.; NREL Report No. PR6A20-58606.

Mendelsohn, M.; Harper, J. (2012). §1603 Treasury Grant Expiration: Industry Insight on Financing and Market Implications. 32 pp.; NREL Report No. NREL/TP-6A20-53720.

Schwabe, P.; Lensink, S.; Hand, M. (2011). IEA Wind Task 26 - Multi-national Case Study of the Financial Cost of Wind Energy; Work Package 1 Final Report. 122 pp.; NREL Report No. TP-6A20-48155.

Wiser, R.; Bolinger, M.; Barbose, G.; Darghouth, N.; Hoen, B.; Mills, A.; Weaver, S.; Porter, K.; Buckley, M.; Oteri, F.; Tegen, S. (2014). 2013 Wind Technologies Market Report. 96 pp.; NREL Report No. TP-5000-62345; DOE/GO-102014-4459.

\section{Appendix 6-A. Sample Size and Project Data for the United States}

This appendix contains statistics representing wind project characteristics that are illustrated in the chapter. Table 6-7 describes the sample size of data represented in the subsequent tables. The values in the table correspond to the installed wind project capacity in a given year, or the percentage of annual installed capacity, that is included in the database. For example, an entry of 
$100 \%$ for Wind Turbine Hub Height means that the statistics shown in the corresponding table and figure for hub height represent $100 \%$ of the turbines installed in that year.

Much of the data included in this chapter were compiled by Lawrence Berkeley National Laboratory (Berkeley Lab) from a variety of sources, including the American Wind Energy Association (AWEA), the U.S. Energy Information Administration (EIA), and the Federal Energy Regulatory Commission (FERC). A summary of the many data sources and a list of specific references may be found in the 2013 Wind Technologies Market Report (Wiser et al., 2014). Data on wind power capacity additions in the United States (as well as wind power projects) are based largely on information provided by AWEA, although minor methodological differences may yield slightly different numbers from AWEA (2014a) in some cases. In other cases, the data shown here represent only a sample of actual wind power projects installed in the United States; furthermore, the data vary in quality. As such, emphasis should be placed on overall trends, rather than on individual data points. 
Table 6-6. Sample Size for the United States

\section{COUNTRY: UNITED STATES}

DEFINITION OF UTILITY SCALE WIND

All land-based wind projects equal to or over $1 \mathrm{MW}$ in size; with all turbines in the project also equal

to or over $1 \mathrm{MW}$; and only including projects that sell electricity to the grid (e.g., project size and

\section{YEAR DATA AGGREGATION}

None required

\section{OTHER NOTES}

Sample size for full load hours varies based on sampling from EIA, and can exceed $100 \%$ by virtue of

\begin{tabular}{|c|c|c|c|c|c|c|}
\hline \multirow[t]{2}{*}{ SAMPLE } & \multicolumn{6}{|c|}{ Capacity (Megwatts) } \\
\hline & 2007 & 2008 & 2009 & 2010 & 2011 & 2012 \\
\hline \multicolumn{7}{|c|}{ Annual Installations -- Land-Based, Utility-Scale Only } \\
\hline Total Wind Power Additions & 5,247 & 8,314 & 9,934 & 5,196 & 6,777 & 13,026 \\
\hline \multicolumn{7}{|l|}{ Sample Size -- Land-Based, Utility-Scale Only } \\
\hline Wind Project Size & 5,247 & 8,314 & 9,934 & 5,196 & 6,777 & 13,026 \\
\hline Wind Turbine Nameplate Capacity Rating & 5,247 & 8,314 & 9,934 & 5,196 & 6,777 & 13,026 \\
\hline Wind Turbine Rotor Diameter & 5,247 & 8,314 & 9,934 & 5,196 & 6,777 & 13,026 \\
\hline Wind Turbine Hub Height & 5,247 & 8,314 & 9,934 & 5,196 & 6,777 & 13,026 \\
\hline Wind Turbine Specific Power & 5,247 & 8,314 & 9,934 & 5,196 & 6,777 & 13,026 \\
\hline Wind Turbine IEC Class & 5,247 & 8,294 & 9,784 & 5,175 & 6,777 & 12,617 \\
\hline Annual Average Wind Speed & 4,664 & 8,262 & 9,194 & 5,003 & 6,389 & 11,764 \\
\hline Full Load Hours (generation in 2013) & 5,282 & 8,521 & 9,426 & 4,733 & 5,760 & 13,368 \\
\hline Investment Costs & 3,211 & 5,509 & 9,497 & 5,128 & 6,343 & 9,171 \\
\hline Operations and Maintenance Costs & na & na & na & na & na & na \\
\hline Financing Costs & na & na & na & na & na & na \\
\hline \multicolumn{7}{|l|}{ Sample Size (\%) -- Land-Based, Utility-Scale Only } \\
\hline Wind Project Size & $100 \%$ & $100 \%$ & $100 \%$ & $100 \%$ & $100 \%$ & $100 \%$ \\
\hline Wind Turbine Nameplate Capacity Rating & $100 \%$ & $100 \%$ & $100 \%$ & $100 \%$ & $100 \%$ & $100 \%$ \\
\hline Wind Turbine Rotor Diameter & $100 \%$ & $100 \%$ & $100 \%$ & $100 \%$ & $100 \%$ & $100 \%$ \\
\hline Wind Turbine Hub Height & $100 \%$ & $100 \%$ & $100 \%$ & $100 \%$ & $100 \%$ & $100 \%$ \\
\hline Wind Turbine Specific Power & $100 \%$ & $100 \%$ & $100 \%$ & $100 \%$ & $100 \%$ & $100 \%$ \\
\hline Wind Turbine IEC Class & $100 \%$ & $100 \%$ & $98 \%$ & $100 \%$ & $100 \%$ & $97 \%$ \\
\hline Annual Average Wind Speed & $89 \%$ & $99 \%$ & $93 \%$ & $96 \%$ & $94 \%$ & $90 \%$ \\
\hline Full Load Hours (generation in 2013) & $101 \%$ & $102 \%$ & $95 \%$ & $91 \%$ & $85 \%$ & $103 \%$ \\
\hline Investment Costs & $61 \%$ & $66 \%$ & $96 \%$ & $99 \%$ & $94 \%$ & $70 \%$ \\
\hline Operations and Maintenance Costs & na & na & na & na & na & na \\
\hline Financing Costs & na & na & na & na & na & na \\
\hline
\end{tabular}


Table 6-7. Wind Project Size Statistics

\begin{tabular}{|l|r|r|r|r|r|r|}
\hline Wind Project Size (MW) & \\
\hline & 2007 & 2008 & 2009 & 2010 & 2011 & 2012 \\
\hline $\mathrm{n}$ (\# projects) & 51 & 103 & 108 & 66 & 90 & 141 \\
\hline median & 80.0 & 76.5 & 98.9 & 65.6 & 47.3 & 80.0 \\
\hline 25th percentile & 34.5 & 25.0 & 44.3 & 20.0 & 12.0 & 24.6 \\
\hline 75th percentile & 140.4 & 121.9 & 120.0 & 103.5 & 119.6 & 138.0 \\
\hline minimum & 1.5 & 1.5 & 1.5 & 1.0 & 1.5 & 1.5 \\
\hline maximum & 400.5 & 298.5 & 400.3 & 300.0 & 443.9 & 470.4 \\
\hline average & 102.9 & 80.7 & 92.0 & 78.7 & 75.3 & 92.4 \\
\hline
\end{tabular}

Salient Notes: All projects $>=1 \mathrm{MW}$, with all turbines $>=1 \mathrm{MW}$, and which were not behind the meter (i.e., "on-site" in terms of off-taker)

Table 6-8. Wind Turbine Nameplate Capacity Rating Statistics

\begin{tabular}{|l|r|r|r|r|r|r|} 
Wind Turbine Nameplate Capacity Rating (kW) \\
\hline & 2007 & 2008 & 2009 & 2010 & 2011 & 2012 \\
\hline $\mathrm{n}$ (\# turbines) & 3188 & 4986 & 5682 & 2889 & 3434 & 6673 \\
\hline median & 1500 & 1500 & 1500 & 1500 & 1800 & 1800 \\
\hline 25th percentile & 1500 & 1500 & 1500 & 1500 & 1600 & 1600 \\
\hline 75th percentile & 1800 & 2000 & 2000 & 2100 & 2300 & 2300 \\
\hline minimum & 1000 & 1000 & 1000 & 1000 & 1500 & 1000 \\
\hline maximum & 3000 & 3000 & 3000 & 3000 & 3000 & 3600 \\
\hline average & 1645.9 & 1667.5 & 1748.3 & 1798.7 & 1973.5 & 1952.3 \\
\hline
\end{tabular}

Salient Notes: All turbines with a known capacity $>=1 \mathrm{MW}$, for all projects $>=1 \mathrm{MW}$ that were not behind the meter (i.e., "on-site" in terms of off-taker)

Table 6-9. Turbine Rotor Diameter Statistics

\begin{tabular}{|l|r|r|r|r|r|r|} 
Wind Turbine Rotor Diameter $(\mathbf{m})$ \\
\hline & 2007 & 2008 & 2009 & 2010 & 2011 & 2012 \\
\hline $\mathrm{n}$ (\# turbines) & 3188 & 4986 & 5682 & 2889 & 3434 & 6673 \\
\hline median & 77 & 77 & 82 & 82.5 & 90 & 96 \\
\hline 25th percentile & 77 & 77 & 77 & 77 & 82.5 & 82.5 \\
\hline 75th percentile & 82 & 82.5 & 88 & 88 & 96 & 100 \\
\hline minimum & 61.4 & 61.4 & 61.4 & 59 & 76.8 & 61.4 \\
\hline maximum & 96 & 96 & 99 & 101 & 101 & 117 \\
\hline average & 79.1 & 79.4 & 81.7 & 84.4 & 89.2 & 93.6 \\
\hline
\end{tabular}

Salient Notes: All turbines with a known rotor diameter (i.e., not missing) and capacity $>=1 \mathrm{MW}$, for all projects >= $1 \mathrm{MW}$ that were not behind the meter (i.e., "on-site" in terms of off-taker) 
Table 6-10. Wind Turbine Specific Power Statistics

\begin{tabular}{|l|r|r|r|r|r|r|} 
Wind Turbine Specific Power $\left(\mathbf{W} / \mathbf{m}^{2}\right)$ \\
\hline & 2007 & 2008 & 2009 & 2010 & 2011 & 2012 \\
\hline $\mathrm{n}$ (\# turbines) & 3188 & 4986 & 5682 & 2889 & 3434 & 6673 \\
\hline median & 322.1 & 322.1 & 322.1 & 322.1 & 299.3 & 294.4 \\
\hline 25th percentile & 322.1 & 322.1 & 322.1 & 287.1 & 282.9 & 251.1 \\
\hline 75th percentile & 337.7 & 337.7 & 338.6 & 336.4 & 322.1 & 314.4 \\
\hline minimum & 312.4 & 280.6 & 280.6 & 280.6 & 229.2 & 203.7 \\
\hline maximum & 471.6 & 471.6 & 471.6 & 471.6 & 471.6 & 471.6 \\
\hline average & 330.7 & 332.1 & 329.1 & 318.4 & 314.8 & 285.5 \\
\hline
\end{tabular}

Salient Notes: All turbines with a known specific power (i.e., not missing) and capacity $>=1 \mathrm{MW}$, for all projects >=1MW that were not behind the meter (i.e., "on-site" in terms of off-taker)

Table 6-11. Wind Turbine Hub Height Statistics

\begin{tabular}{|l|r|r|r|r|r|r|} 
Wind Turbine Hub Height $(\mathbf{m})$ & \\
\hline & 2007 & 2008 & 2009 & 2010 & 2011 & 2012 \\
\hline $\mathrm{n}$ (\# turbines) & 3188 & 4986 & 5682 & 2889 & 3434 & 6673 \\
\hline median & 80 & 80 & 80 & 80 & 80 & 80 \\
\hline 25th percentile & 79 & 80 & 80 & 80 & 80 & 80 \\
\hline 75th percentile & 80 & 80 & 80 & 80 & 80 & 85 \\
\hline minimum & 65 & 67 & 65 & 70 & 65 & 60 \\
\hline maximum & 105 & 100 & 80 & 100 & 100 & 100 \\
\hline average & 78.2 & 78.5 & 79.0 & 79.8 & 81.1 & 83.9 \\
\hline
\end{tabular}

Salient Notes: All turbines with a known hub height (i.e., not missing) and capacity $>=$ $1 \mathrm{MW}$, for all projects $>=1 \mathrm{MW}$ that were not behind the meter (i.e., "on-site" in terms of off-taker)

Table 6-12. Proportion of Turbines Installed per IEC Class

Wind Turbine IEC Class - Average
Class
\begin{tabular}{|l|r|r|r|r|r|r|}
\hline & 2007 & 2008 & 2009 & 2010 & 2011 & 2012 \\
\hline Class I & $49 \%$ & $52 \%$ & $46 \%$ & $36 \%$ & $21 \%$ & $10 \%$ \\
\hline Class I/II & $2 \%$ & $3 \%$ & $0 \%$ & $0 \%$ & $0 \%$ & $0 \%$ \\
\hline Class II & $48 \%$ & $43 \%$ & $46 \%$ & $45 \%$ & $58 \%$ & $37 \%$ \\
\hline Class II/III & $0 \%$ & $1 \%$ & $3 \%$ & $2 \%$ & $9 \%$ & $19 \%$ \\
\hline Class III & $0 \%$ & $2 \%$ & $4 \%$ & $17 \%$ & $11 \%$ & $33 \%$ \\
\hline Average & 1.5 & 1.5 & 1.6 & 1.8 & 1.9 & 2.3 \\
\hline n (\# turbines) & 3188 & 4976 & 5621 & 2878 & 3434 & 6432 \\
\hline
\end{tabular}

Salient Notes: All turbines with a known IEC class (i.e., not missing) and capacity $>=1$ MW, for all projects $>=1 \mathrm{MW}$ that were not behind the meter (i.e., "on-site" in terms of off-taker). Turbines rated as spanning two classes are identified as such (e.g., Class II/III) and an "average" class is defined for the purpose of showing trends in the average IEC Class (e.g., a Class II/III machine is given an average class of 2.5) 
Table 6-13. Full Load Hours and Capacity Factor Statistics

Full Load Hours in 2013 (equivalent to capacity factor * 8760)
\begin{tabular}{|l|r|r|r|r|r|r|}
\hline \multicolumn{1}{|r|}{ Project COD } & 2007 & 2008 & 2009 & 2010 & 2011 & 2012 \\
\hline median & 2,963 & 2,980 & 2,712 & 2,827 & 2,824 & 2,882 \\
\hline 25th percentile & 2,648 & 2,503 & 2,363 & 2,531 & 2,501 & 2,360 \\
\hline 75th percentile & 3,263 & 3,215 & 3,182 & 3,299 & 3,190 & 3,442 \\
\hline minimum & 1,917 & 1,695 & 1,109 & 1,457 & 1,344 & 1,501 \\
\hline maximum & 4,091 & 3,860 & 4,160 & 4,155 & 4,468 & 4,653 \\
\hline generation-weighted average, not index weighted & 2,930 & 2,919 & 2,745 & 2,886 & 2,798 & 2,924 \\
\hline generation-weighted average, wind index weighted & 2,989 & 2,979 & 2,801 & 2,945 & 2,855 & 2,984 \\
\hline
\end{tabular}

\begin{tabular}{|c|c|c|c|c|c|c|}
\hline \multicolumn{7}{|c|}{ Capacity Factor in 2013 (equivalent to full load hours divided by 8760 ) } \\
\hline & 2007 & 2008 & 2009 & 2010 & 2011 & 2012 \\
\hline median & $33.8 \%$ & $34.0 \%$ & $31.0 \%$ & $32.3 \%$ & $32.2 \%$ & $32.9 \%$ \\
\hline 25th percentile & $30.2 \%$ & $28.6 \%$ & $27.0 \%$ & $28.9 \%$ & $28.5 \%$ & $26.9 \%$ \\
\hline 75th percentile & $37.3 \%$ & $36.7 \%$ & $36.3 \%$ & $37.7 \%$ & $36.4 \%$ & $39.3 \%$ \\
\hline minimum & $21.9 \%$ & $19.4 \%$ & $12.7 \%$ & $16.6 \%$ & $15.3 \%$ & $17.1 \%$ \\
\hline maximum & $46.7 \%$ & $44.1 \%$ & $47.5 \%$ & $47.4 \%$ & $51.0 \%$ & $53.1 \%$ \\
\hline generation-weighted average, not index weighted & $33.4 \%$ & $33.3 \%$ & $31.3 \%$ & $32.9 \%$ & $31.9 \%$ & $33.4 \%$ \\
\hline generation-weighted average, wind index weighted & $34.1 \%$ & $34.0 \%$ & $32.0 \%$ & $33.6 \%$ & $32.6 \%$ & $34.1 \%$ \\
\hline
\end{tabular}

Table 6-14. Average Annual Wind Speed Statistics

Average Annual Wind
Speed
\begin{tabular}{|l|r|r|r|r|r|r|}
\hline & 2007 & 2008 & 2009 & 2010 & 2011 & 2012 \\
\hline $\mathrm{n}$ (\# turbines) & 3181 & 4924 & 5705 & 2866 & 3429 & 6444 \\
\hline median & 7.94 & 8.05 & 7.49 & 7.45 & 7.39 & 7.46 \\
\hline 25th percentile & 7.28 & 7.51 & 6.90 & 7.11 & 6.65 & 6.74 \\
\hline 75th percentile & 8.37 & 8.34 & 8.05 & 8.03 & 7.84 & 7.99 \\
\hline minimum & 5.82 & 4.46 & 5.33 & 5.48 & 4.12 & 4.42 \\
\hline maximum & 9.35 & 9.42 & 8.90 & 8.69 & 8.79 & 9.45 \\
\hline average & 7.79 & 7.82 & 7.45 & 7.46 & 7.24 & 7.35 \\
\hline
\end{tabular}

Salient Notes: For the US, this represents the modeled $80 \mathrm{~m}$ average annual wind speed for each turbine for which such data could be obtained. Data come from AWS Truepower estimates provided to NREL on an $20 \mathrm{~km}$ by $20 \mathrm{~km}$ grid size. These data are not adjusted for site elevation. $n$ equals the number of turbines that could be located via the FAA database for all projects in that year, and therefore associated with AWS modeled wind speeds, rather than the total number of turbines known to exist. In a few cases a higher number of turbines were associated with a project than were actual, but in most cases, only a smaller number of turbines were associated, when other than the exact numbers were mapped. Finally, because the modeled AWS data are on a $20 \times 20 \mathrm{~km}$ grid scale, we would expect that ACTUAL wind speeds seen by the turbines would be higher than that estimated here (aka, turbines will tend to be placed in locations within a $20 \times 20 \mathrm{~km}$ grid that have higher resources than the average for the grid as a whole). 
Table 6-15. Investment Costs Statistics

Wind Project Investment Costs (2012 EUR per
kW)
\begin{tabular}{|l|r|r|r|r|r|r|}
\hline & 2007 & 2008 & 2009 & 2010 & 2011 & 2012 \\
\hline median & 1437 & 1590 & 1714 & 1769 & 1688 & 1550 \\
\hline 25th percentile & 1261 & 1402 & 1582 & 1588 & 1602 & 1420 \\
\hline 75th percentile & 1549 & 1680 & 1878 & 1938 & 1855 & 1716 \\
\hline minimum & 1043 & 1176 & 1090 & 1400 & 1157 & 1095 \\
\hline maximum & 1717 & 2019 & 2633 & 2532 & 3552 & 3113 \\
\hline capacity-weighted average & 1418 & 1607 & 1734 & 1730 & 1658 & 1494 \\
\hline
\end{tabular}

Wind Project Investment Costs (2012 USD per
kW)
\begin{tabular}{|l|r|r|r|r|r|r|}
\hline & 2007 & 2008 & 2009 & 2010 & 2011 & 2012 \\
\hline median & 1846 & 2043 & 2203 & 2272 & 2169 & 1992 \\
\hline 25th percentile & 1620 & 1802 & 2032 & 2040 & 2058 & 1824 \\
\hline 75th percentile & 1991 & 2159 & 2413 & 2490 & 2383 & 2205 \\
\hline minimum & 1340 & 1512 & 1400 & 1798 & 1487 & 1407 \\
\hline maximum & 2206 & 2594 & 3383 & 3253 & 4563 & 4000 \\
\hline capacity-weighted average & 1822 & 2065 & 2228 & 2223 & 2131 & 1919 \\
\hline
\end{tabular}

Table 6-16. Weighted Average Cost of Capital Statistics

\begin{tabular}{|l|r|r|r|r|r|r|}
\hline Financing Cost (After-Tax WACC) \\
\hline median & 2007 & 2008 & 2009 & 2010 & 2011 & 2012 \\
\hline 25th percentile & & & & & & \\
\hline 75th percentile & & & & & & \\
\hline minimum & & & & & & \\
\hline maximum & $7.7 \%$ & $7.1 \%$ & $6.4 \%$ & $6.4 \%$ & $6.2 \%$ & $5.9 \%$ \\
\hline average & $8.7 \%$ & $9.2 \%$ & $10.5 \%$ & $9.8 \%$ & $9.6 \%$ & $9.5 \%$ \\
\hline
\end{tabular}

Salient Notes: For the US, the data shown here represent a market-wide estimate of min, max, and weighted-average financing costs. Estimates are based on generic historical data from Bloomberg New Energy Finance on the cost of third-party tax equity and project-level 15-year term debt, as well as LBNL estimates of the cost of sponsor equity. Representative project-level capital structures are derived from financial modeling; these determine the mix of the three capital sources, and hence the WACC, under various financing structures. The min and max WACC are simply drawn from the various financing structures that are relevant in each year, while the capacity-weighted average WACC is based on LBNL estimates of the percentage of installed capacity utilizing the various financing structures in each year. All values are expressed in after-tax, nominal terms. 


\section{Appendix 1 Methodology}

This appendix describes the methodology for using the IEA Wind Task 26 Cash Flow Model to estimate LCOE, policy impact, and required revenue.

The cash flow model provides significant flexibility in representing detailed information for a given wind project. In order to produce results that can be compared among different countries, simplifications are applied. This approach results in greater transparency and ease of replication. This analysis is conducted in real terms, rather than nominal. Model inputs are real values and inflation is assumed to be $0 \%$ to provide real outputs. Translation between real and nominal values and associated inflation rates are discussed in each country chapter. A common assumption across all countries is that the LCOE estimates include 20 -year straight-line depreciation of $100 \%$ of the CAPEX; this is assumed to be representative of generic tax treatment across all countries for any asset. Tax treatment such as accelerated depreciation schedules specific to wind energy is considered a policy incentive and is not included in the LCOE estimate.

The basic approach consists of the following steps:

1. Estimate LCOE for a typical project in a given country. The model input values required to estimate LCOE are summarized in the following table. ${ }^{58}$ For simplification, the typical project finance structure in each country is represented with an after-tax real WACC that reflects both equity and debt contributions and the typical tax deductions associated with interest repayments. This value is input into the model as the rate of return on equity, and a project with $100 \%$ equity is modeled. No subsidy or other policy-related mechanism is represented. The LCOE cash flow tab contains the calculation of the wind project LCOE. The value on the Input_Output tab of the cash flow model, LC, represents the LCOE for this representative wind project in a given country.

\footnotetext{
${ }^{58}$ A $100 \%$ equity project is assumed, and the real WACC value is input as the required return on equity. Inflation $=$
} $0 \%$ in the cash flow model. The depreciation period is 20 years. The tax capability is unlimited. 
Table A1-1. Wind Energy Project Features Used to Estimate LCOE

\begin{tabular}{|c|c|}
\hline Characteristics & Unit \\
\hline Unit size & MW \\
\hline Number of turbines & \# \\
\hline Rotor diameter / Hub height & $\mathrm{m} / \mathrm{m}$ \\
\hline Annual average wind speed at hub height & $\mathrm{m} / \mathrm{s}$ \\
\hline Production & full load hours \\
\hline Economic life & years \\
\hline \multirow[t]{2}{*}{ Investment costs } & $\$ 2012 / \mathrm{kW}$ \\
\hline & $€_{2012} / \mathrm{kW}$ \\
\hline \multirow[t]{2}{*}{ O\&M costs (total, expressed in fixed-costs terms) } & $\$_{2012} / \mathrm{kW}-\mathrm{yr}$ \\
\hline & $€_{2012} / \mathrm{kW}-\mathrm{yr}$ \\
\hline Decommission costs & $€ c t / k W h$ \\
\hline WACC (nominal / real) & $\%$ \\
\hline Corporate tax rate & $\%$ \\
\hline
\end{tabular}

2. Estimate the revenue requirements excluding policy incentives in a given country. Information entered on the Policy tab of the cash flow model is used to represent incentives available to the wind project in a given country. These range in variety and influence and are summarized in the following table. Note that this table includes the market price of electricity which is not input into the model in this analysis. ${ }^{59}$ The value on the Input_Output tab of the cash flow model, FG, represents the financial gap, or revenue required in addition to the available subsidies to recover the total cost of constructing and operating the wind plant.

\footnotetext{
${ }^{59}$ The cash flow model includes the capability of representing anticipated revenue for a given project, which is incorporated into the FG calculation. Because this study involves representative wind plant characteristics, rather than characteristics of a specific wind plant, the comparison was made to representative electricity revenue ranges rather than a specific electricity price stream external to the model.
} 
Table A1-2. Wind Energy Policy Incentives Used to Estimate Revenue Requirements

\begin{tabular}{|l|l|}
\hline Policy or Revenue Parameters & Unit \\
\hline Market Price Electricity & $\$ 2012 / \mathrm{kWh}$ \\
\hline FIT revenue & $\$_{2012} / \mathrm{kWh}$ \\
\hline FIT policy period & years \\
\hline Upfront tax-based subsidy before tax & $\%$ \\
\hline Production-based tax credits & $\$ 2012 / \mathrm{kWh}$ \\
\hline Production-based tax credit policy period & years \\
\hline Accelerated Depreciation period & years \\
\hline Reactive power bonus & $\$ 2012 / \mathrm{kWh}$ \\
\hline Low voltage ride through bonus & $\$ 2012 / \mathrm{kWh}$ \\
\hline Market certificates & $\$ 2012 / \mathrm{kWh}$ \\
\hline
\end{tabular}

3. Estimate the impact of policy incentives in a given country in offsetting the LCOE of a wind project. The difference between the Input_Output tab value LC and FG is the impact of the policy incentives represented on the Policy tab of the cash flow model. The three model output values are summarized in the table below.

Table A1-3. Cash Flow Model Outputs

\begin{tabular}{|c|l|}
\hline Model Estimate & Unit \\
\hline Levelized cost of energy & $\left(\$_{2012} / \mathrm{MWh}\right)$ \\
\hline Levelized cost of energy & $\left(€_{2012} / \mathrm{MWh}\right)$ \\
\hline Value of policy & $\left(\$_{2012} / \mathrm{MWh}\right)$ \\
\hline Value of policy & $\left(€_{2012} / \mathrm{MWh}\right)$ \\
\hline Revenue Required & $\left(\$_{2012} / \mathrm{MWh}\right)$ \\
\hline Revenue Required & $\left(€_{2012} / \mathrm{MWh}\right)$ \\
\hline
\end{tabular}

4. Compare the required revenue to appropriate market electricity price references in a given country. For each country there are different revenue streams available to a wind project owner for the electricity produced. These values are compared to the estimated revenue required for the representative wind plant(s) in a given country in order to demonstrate that the representation described in each chapter does indeed reflect characteristics of projects that could be realized in that country. In this report, the comparison with market electricity prices is done external to the model in the chapter discussion rather than using the cash flow model to calculate a financial gap. 